
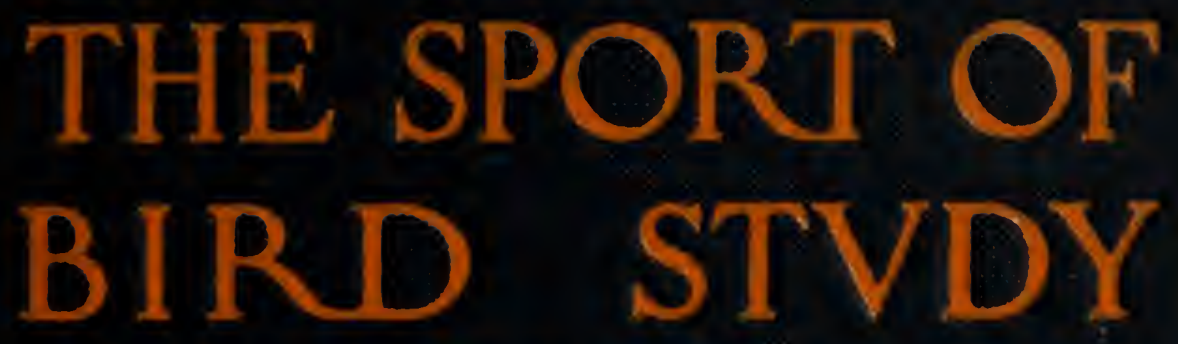

BY HERBERT K. JOB 


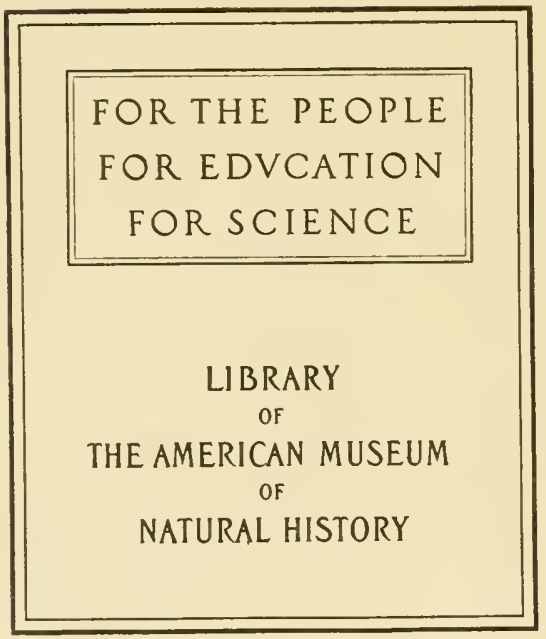




THE SPORT OF BIRD STUDY 


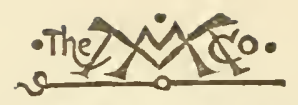

THE MACMILLAN COMPANY

NEW YORK - BOSTON - CHICAGO - DALLAS ATLANTA - SAN FRANCISCO

MACMILLAN \& CO., LmMited

LONDON - BOMBAY - CALCUTTA MIELBOURNE

THE MACMILLAN CO. OF CANADA, LTD. TORONTO 



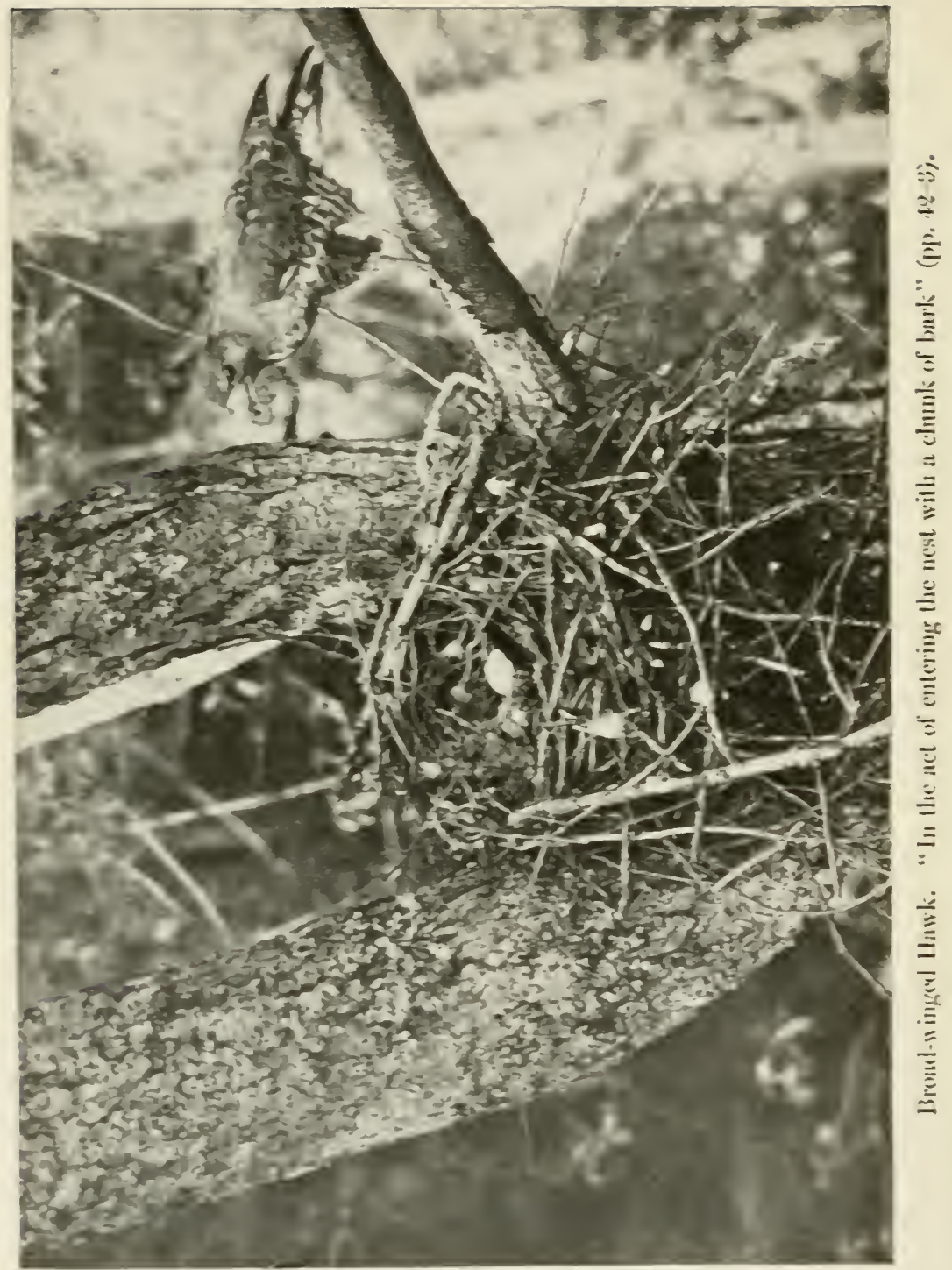




\section{BY \\ HERBERT KEIGHTLEY JOB}

Author of "How To Study Birds," "Wild Wings" and "Among The Water-Forcl." Member of The American Ornithologists" Union, etc.

PROFUSELY ILLUSTRATED IVITH PHOTOGRAPHS FROM LIFE BY THE AUTHOR

ล̇̃ư đูurk

THE MACMILLAN COMPANY

I922

All rights reserved 
PRINTED IN THE UNITED STATES OF AMERICA

22.88683 func 28

COPYRIGHT, 1908

BY THE MACMILLAN COMPANY

New Printing. February, 1922

FERRIS PRINTING COMPANY

NEW YORK 


\section{TO MY SON \\ GEORGE CURTISS JOB \\ and all other \\ Real Live American Boys}





\section{TABLE OF CONTENTS}

CHAPTER
PAGH

I The Appeal of The Syort . . . . . . . . 1

II Hunting Game-Birds mith the Camera. (Upland Game Birds.) . . . . . . . . . . 13

III The Robbers of the Falls, and Others. (Hawks.) • 34

IV The Bird of Night. (Owls.) • • • • • 57

V Strange Bed-Fullows. (Cuckoos and Kringfishers.) • 77

VI Knigits of tin Chisel. (Woodpeckers.) . • . 87

VII Birds with a Handicap. (Goatsuckers and Hummers.) 101

VIII Profisional Fly-Catching. (Flycatchers.) . • . 124

IX Crow Relatives. (Crows, Jays, Blackbirds, etc.) • . 139

X A Puzzle in Birds. (Finches, Sparrows, etc.) • . 156

XI Our Priceless Swallows and Swifts . • . . 178

XII Fout Neighbors Diverse. (Tanagers, Waxwings, Shrikes,

Vircos.) . . . . . . . . . . 191

XIII Featheren Gems. (The Warblers.) • . . . 206

XIV Thrush Cousins. (Thrashers, Wrens, Titmice, Kinglets,

Thrushes, etc.) . . . . . . . . 830

XV Water-Bird Waifs. (Wading and Swimming Birds.) . 251 The Bird-House of Science of N. E. North America . 277

A Bird Calendar . . . . . . . 280

INDEX I

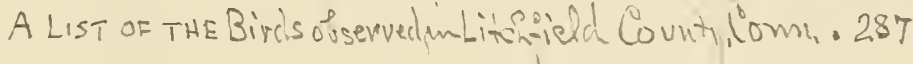





\section{ILLUSTRATIONS}

Broad-winged Hawk

Frontispiece

FACING

PAGE

Dusky or Black Duck . . . . . . . . . . 2

Great Horned Owl incubating . . . . . . . . . 3

Ruffed Grouse on nest . . . . . . . . . . . 6

Nighthawk incubating; normal pose . . . . . . . 7

Northern Yellow-throat (female) about to feed young . . . 16

Woodcock on nest . . . . . . . . . . . 17

Woodcock on nest, showing surroundings . . . . . . 20

Young Woodcock . . . . . . . . . . . 20

Wilson's Snipe . . . . . . . . . . . . 21

Bob White on nest . . . . . . . . . . . 24

Nest and brood of Quail . . . . . . . . . . 24

Ruffed Grouse incubating . . . . . . . . . . 25

Ruffed Grouse in confinement . . . . . . . . . 25

Broad-winged Hawk on nest . . . . . . . . . 42

Young Broad-wings . . . . . . . . . . . 43

Home life of the Red-tailed Hawk . . . . . . . . 50

Red-tailed Hawk . . . . . . . . . . . 50

Three little Sharp-shinned Hawks . . . . . . . . 51

Nest of Marsh Hawk . . . . . . . . . . 51

Nest of Red-shouldered Hawk . . . . . . . . . 58

The Cooper's Hawks' nest by the falls . . . . . . . 58

Young Barred Owl . . . . . . . . . . . 59

Great Horned Owl . . . . . . . . . . . 59

Young Long-eared Owl hiding . . . . . . . . . 66 


\section{ILLUSTRATIONS}

FACING

PAGE

Young Long-eared Owls . . . . . . . . . . 66

Young Screech Owl in position of defense . . . . . . 67

Screech Owl . . . . . . . . . . • . 67

"On it sat a Black-billed Cuckoo" . . . . . . . . 78

Nest of Black-billed Cuckoo . . . . . . . . . 79

Young Black-billed Cuckoos in nest . . . . . . . 79

Kingfisher (adult) . • . . . . • • . • . 82

Young Kingfisher leaving nest-burrow . . . . . . . 83

Young Kingfishers . . . . . . . . . . . 83

"A Flicker stuck its head out of the nest-hole" . . . . . 90

Flicker, or Yellow-hammer (female), feeding young in hole . . 90

Family of Young Flickers . . . . . . . . . 91

Ned got the Hairy Woodpecker . . . . . . . . . 98

Downy Woodpecker attracted by suet . . . . . . . 98

Downy Woodpecker . . . . . . . . . . . 98

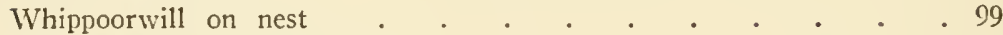

Young Whippoorwills in nest . . . . . . . • . 99

Nighthawk . • . . . . . • . • • • . 108

Young Nighthawks . . . . . . . . . . . 108

Nighthawk on eggs, alarmed . . . . . . . . . . 109

Nighthawk by her eggs . . . . . . . . . . 109

Hummer "in the midst of the feeding comedy" . . . . . . 116

Humming Bird incubating . . . . . . . . . 116

Hummer and young . . . . . . . . . . . . 117

Young Hummers in nest . . . . . . . . . . 117

Kingbird on nest . . . . . . . . . . . . 124

Kingbird scolding . . . . . . . . . . . 125

The entire Kingbird family . . . . . . . . . 125

Phoebe and her new husband in the garden . . . . . . 130

Phoebe on nest. . . . . . . . . . . . 130

Snapshot of Wood Pewee . . . . . . . . . . 131

Young Least Flycatcher . . . . . . . . • . 131 


\section{ILLUSTRATIONS}

FACING

PAGE

The Alder Flycatcher

Typical nest of Alder Flycatcher . . . . . . . . 137

Alder Flycatcher.

Young Crows in nest . . . . . . . . . . 140

Young Crows . . . . . . . . . . . . . 141

Blue Jay

. 146

Rusty Grackle

. 147

Nest of Meadowlark

Nest of Orchard Oriole . . . . . . . . . . 150

Young Orchard Orioles . . . . . . . . . . 150

Male Bobolinks . . . . . . . . . . . . 151

Five young Bobolinks in nest . . . . . . . . . 151

Tree Sparrow eating hay seed thrown on the snow . . . .160

Pine Grosbeak about to drink . . . . . . . . . 160

Female Rose-breasted Grosbeak incunating . . . . . . . 161

Pair of White-winged Crossbills . . . . . . . . . 161

Young Field Sparrows in nest . . . . . . . . 164

Young Goldfinches, ready to leave nest . . . . . . . 164

Nest of Swamp Sparrow . . . . . . . . . . 165

Nest of Vesper Sparrow . . . . . . . . . . 165

Nest of Chippy . . . . . . . . . . . . 172

Chipping Sparrows . . . . . . . . . . . 172

Young Barn Swallows on nest . . . . . . . . . 173

Young Barn Swallow . . . . . . . . . . 173

Eave Swallows . . . . . . . . . . . . . . 182

Fledgling Eave Swallow . . . . . . . . . . . . 182

Tree Swallow (male) and nest . . . . . . . . . 183

Tree Swallow . . . . . . . . . • . 183

Young Tree Swallows . . . . . . . . . . . . . 183

Purple Martins near their nest in hole of stub . . . . . 186

Bank Swallow at nest-hole in gravel bank . . . . . . 186

Young Chimney Swifts by their nest . . . . . . . 187 


\section{ILLUSTRATIONS}

FACING

PAGE

Young Chimney Swift

Nest of Scarlet Tanager

Young Cedar Waxwings

.194

Red-eyed Vireo incubating

.195

Red-eyed Vireo near young

.195

Red-eyed Vireo feeding young Cowbirds . . . . . . 204

Black and White Creeping Warbler . . . . . . 205

Black and White Creeping Warbler on nest . . . . . . 205

Nest of Black-throated Blue Warbler . . . . . . . 218

Nest of Yellow-breasted Chat . . . . . . . . 218

Oven-bird on nest . . . . . . . . . . . . . . . . . . . . . . .

Louisiana Water Thrush on nest . . . . . . . . . 219

Redstart on nest . . . . . . . . . . . . . . . 224

Chestnut-sided Warbler on nest . . . . . . . . . 224

Nest of Chestnut-sided Warbler . . . . . . . . 225

The condition of the Chestnut-sided Warbler's nest two days' later . 225

Yellow Warbler feeding young in nest . . . . . . . . 228

Northern Yellow-throat . . . . . . . . . . . 228

Brown Thrasher (male) and young . . . . . . . 229

Brown Thrasher (female) . . . . . . . . . . 236

Male Brown Thrasher, shielding young in nest . . . . . 236

Catbird in shrubbery . . . . . . . . . . .237

Catbird on nest . . . . . . . . . . . . . . . . . . . . .

House IVren entering nest . . . . . . . . . 240

House Wren emerging from nest in old can . . . . . .240

Short-billed Marsh Wren . . . . . . . . . . . 241

Nest of Short-billed Marsh Wren . . . . . . . . . . . . . . .

Chickadees . . . . . . . . . . . . . 244

White-breasted Nuthatch . . . . . . . . . . . 244

Wood Thrush incubating . . . . . . . . . . . . . . . . . . . . 245

Young Wood Thrushers, ready to leave nest . . . . . . . 245

Spotted Sandpiper scolding . . . . . . . . . . . 254 


\section{ILLUSTRATIONS}

FACING

PAGE

Semi-palmated Sandpiper feeding . . . . . . . . 254

Nest of Sora . . . . . . . . . . . . . . . . . . . . . . . . . . . . .

Young American Bitterns . . . . . . . . . . . 255

Young Least Bittern . . . . . . . . . . . 260

Green Heron and nest . . . . . . . . . . . . . 261

Green Heron incubating . . . . . . . . . . . 261

Young Wood Duck . . . . . . . . . . . . . 266

The Horned Grebe ashore . . . . . . . . . . . 267

Red-breasted Merganser . . . . . . . . . . . 272

The Horned Grebe . . . . . . . . . . 272 



\section{THE SPORT OF BIRD STUDY}





\section{THE SPORT OF BIRD STUDY}

\section{CHAPTER I}

THE APPEAL OF THE SPORT

T'VE got the Wood Duck, I've got the Wood Duck, I've got him, I've got him!' This excited yelling brought me through the thicket in a hurry, out to the margin of the boggy pond. I arrived just in time to see my fifteen-year-old enthusiast capering like a jumping-jack, and catch a glimpse of a flying duck disappearing like a meteor.

"Got him, have you?" I said. "Produce him, then! Spread him out and let's look him over. Then we'll have roast duck!"

"He's just gone out there through those trees," cried Ned, indicating the course of the recent meteorite, " and I'm dead sure it's a Wood Duck, positive! 'That makes number 149 on my year's list, and I know there's a brood of Black Ducks in here, too; I heard one quacking. If I see them, that will make 150. Oh, it just makes me crazy!"

"Yes, that was a Wood Duck all right. I saw it go," I replied, "and you've certainly got him to your' credit, 


\section{THE APPEAL OF 'THE SPORT}

but you mustn't get so excited this hot August weather, or you'll have a sunstroke."

"Hang the sunstroke," exclaimed Ned, "I'm awful glad you brought me in here. You said I'd get the Wood Duck, but I'd tried so many times I was afraid I'd miss it again. This is certainly a dandy place, and I'm coming here every day for awhile. But when is the best time of day for ducks? I want to see the whole flock of Wood Ducks, and of course the Black Ducks, though I saw some of those fellows last year." "You would be liable to start them up at any time, while they are resting and sunning themselves in the swamp," I told him, "but at dusk they begin to fly around to feed, and dawn is another good time, too. But it would be hard for you to get here so early, and the grass would be drenching wet."

"Hard!" he cried. "You're a great man to talk so, for I've heard you tell of your getting up at two and driving twenty miles before light to shoot ducks in the fall. Don't you think I've got some sporting blood as well as yourself, even if I don't murder them the way you used to?"

"Well, now, you're getting on to a rather delicate subject," I replied. "I know you're an early bird, and I'm glad you are an enthusiast, and that we both know how to find more fun with the birds than by killing them. Of course there's nothing wrong in shooting I lawful game in moderation, but it's simply this, that the new way is so much better than the old that we 


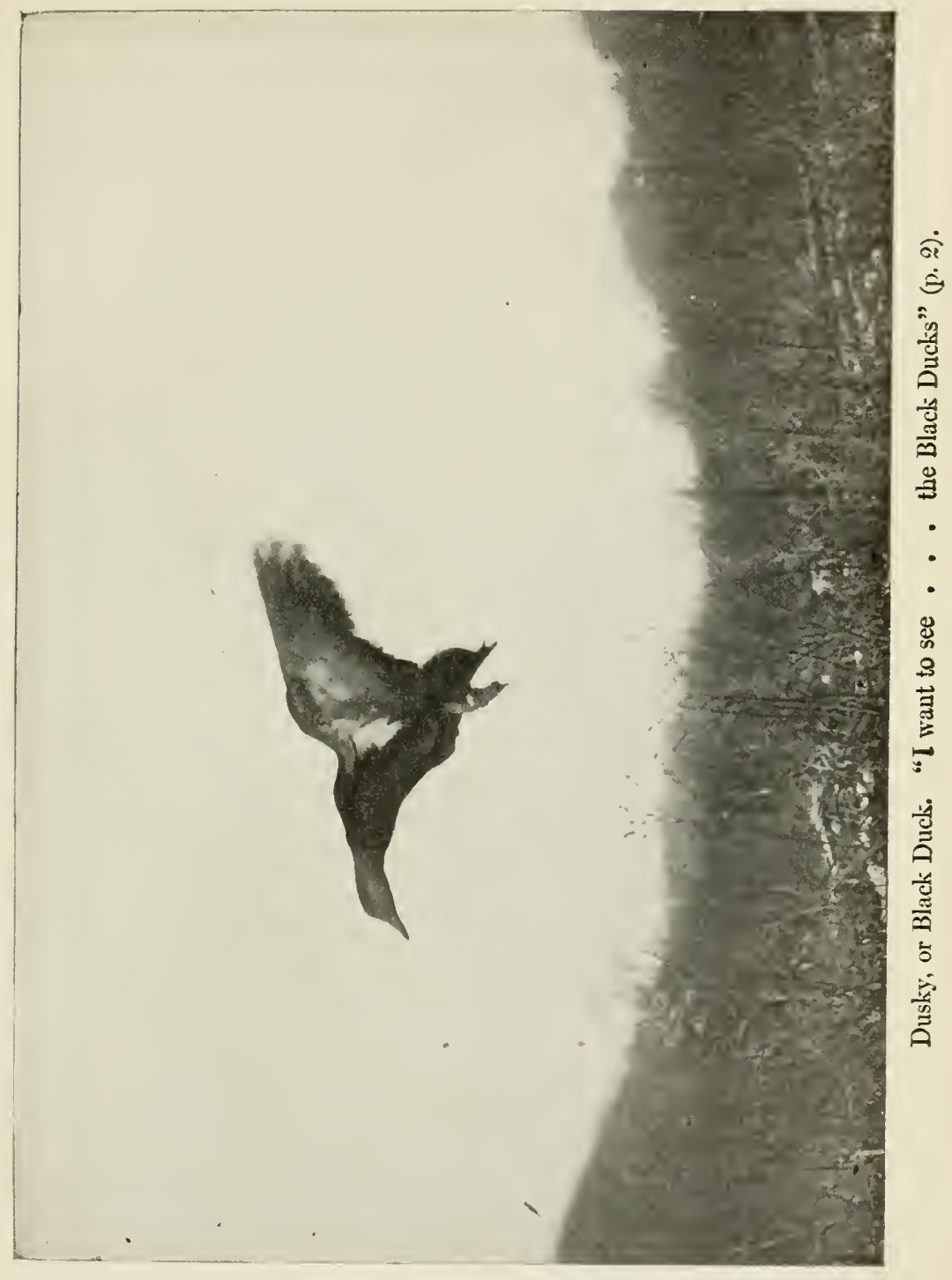




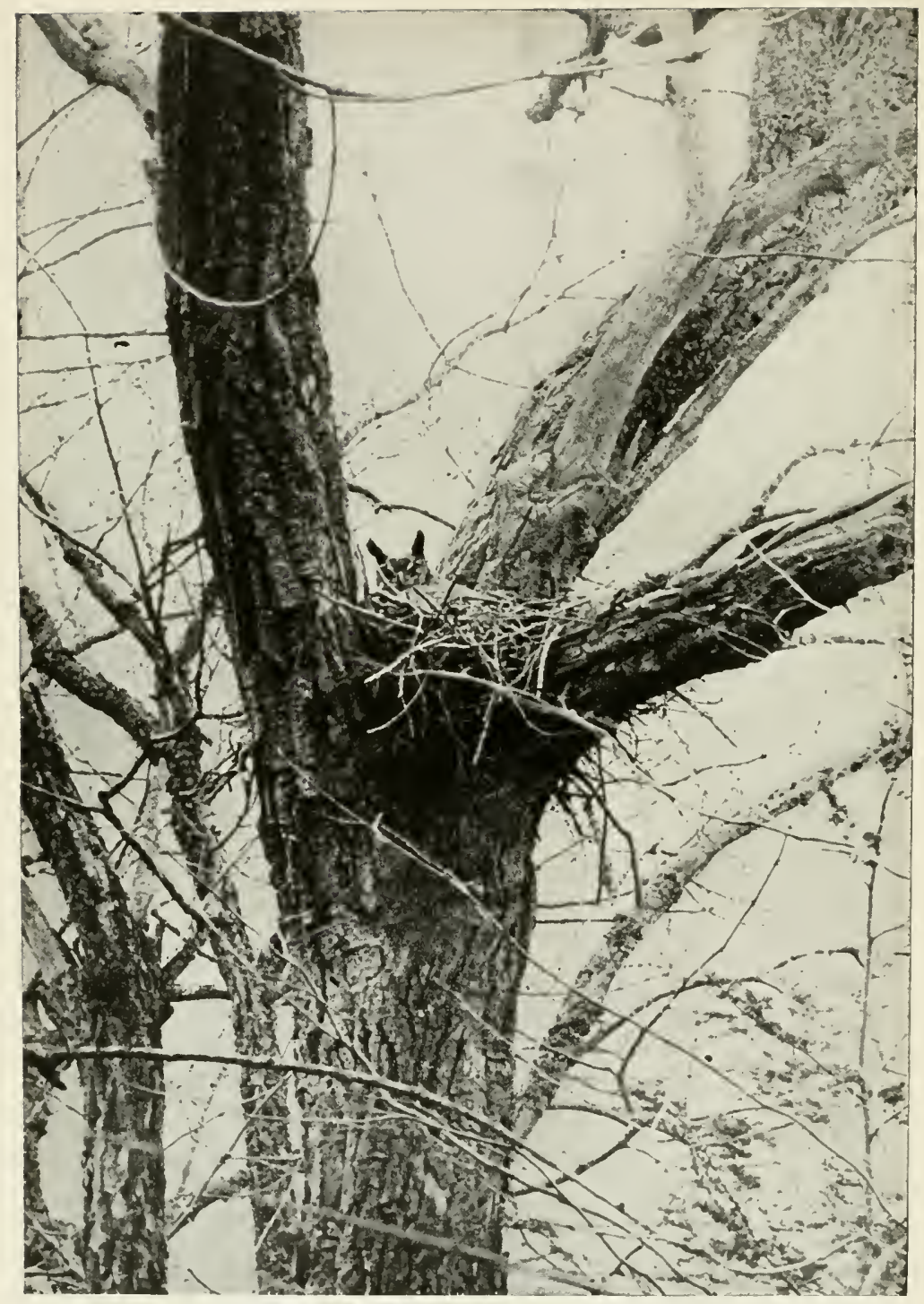

Great Homed Owl incubating. "An incentive such as an old Ilont $\mathrm{Owl}$ (p. 4). 


\section{THE APPEAL OF THE SPORT}

don't care for shooting. Gunners can hunt only in the fall, but our hunting lasts the whole year. Their game, too, is limited to a few kinds, while we have every sort of bird that flies."

So we talked along till we came to the village, agreeing to go to the pond next day at dusk and try to "get" the Black Duck.

While Ned is gone, it is a good chance to talk behind his back and tell a little about him.

A great many people nowadays are interested in birds, and many schools have taken it up as a study and recreation combined. This is the case in the school which Ned attends. They have colored pictures of native birds pinned up on the walls, and charts which explain in an easy way the classification of birds, the groups into which they are divided, and which kinds, or species, of birds are likely to be found in that locality, and at what seasons. The teachers take parties of their pupils out on excursions or "bird walks," noticing the flowers and trees as well, or any other interesting objects, and grand good times they have. Several members of a party have field or opera glasses to see the shier birds more plainly, and so tell what they are. These boys or girls soon come to recognize all the common birds about as far off as they can see them, and are able to give them their right names. At school they keep a list of the birds seen and identified during the year, and each scholar is given credit for the ones he is the first to find, so that competition becomes very keen. 


\section{THE APPEAL OF THE SPORT}

One day I went out to the athletic field to see the boys play a game of baseball. It was the fifth of May, and just across the road which bordered the field I saw and heard two male Bobolinks, the first arrivals in that locality. I wondered whether the boys would notice them, but they did, and after the game there was a grand race to report the Bobolink for the list.

Out of school hours some of the boys, on their own hook, scour the fields and woods for miles around, and Ned is one of these. Young as he is, he has already come to know the birds wonderfully well, and he seldom meets one he cannot recognize, if only he has a good glance at it. There is keen rivalry among these boys as to who can see and identify the largest number of kinds of birds each year. This sends them actively scouring around outdoors in all sorts of places, and at all times, too, winter as well as summer. It is splendid exercise, especially the climbing of the steep wooded hills, up over the rocks, scrambling through thickets of mountain laurel. There is genuine sport in this in itself, yet an incentive, such as an old Hoot Owl somewhere in those wild, secluded woods up near the summit, makes it doubly exciting. There are plenty of Ruffed Grouse in these fastnesses which can be pursued, either with the gun in the fall, or without the gun at any time-to find their nests, to watch the mother lead her brood, to learn where they stay at different hours of the day, where they go when flushed, how many times one can put up the same bird, and so on. 


\section{THE APPEAL OF THE SPOR'T}

The wild places also contain birds which are rare, or not so well known, and there is always a feeling of expectancy and excitement, because at any moment something may turn up. This is particularly true of the seasons of migration, in spring and fall. Spring is inspiring, with its soft breezes and opening flowers, the fragrant odors of earth and woods, the procession of the birds in their choicest plumages, full of song and joy. Autumn is energizing with its snappy air, bidding one be active, the falling of the nuts, the whirring flight of game birds, the restless activity of passing migrant hordes whose song is now dissolved into motion. As the leaves shower down, how fine it is to see through the woods again, and to get the grand views from the hillsides.

Best of all, perhaps, is the nesting season. Ned does not collect eggs, because there are museums available, and there is nothing worth while to be learned from the mere possession of eggshells of his own. Indeed, he is a member of the Audubon Society, whose motto is "A bird in the bush is worth two in the hand," and prefers to have plenty of birds to see and enjoy rather than to join in the robbing and killing which is stripping this country of its beautiful wild life. In nesting time the birds are more familiar and intimate. Find a nest, and one can then visit the bird at will, watch the pretty creatures at close range, learn their habits, how the young are fed and cared for, and also secure photographs from life. Besides, one learns the 


\section{THE APPEAL OF THE SPORT}

haunts of the various birds, the times each season when the different species breed, how they build their nests, and any number of other interesting things.

The boys, however, do not have this fun all to themselves. It appeals just exactly as much to strong, active men. I began when I was a young boy, and now, after thirty years of the sport, I like it just as well as ever. And there are thousands, increasing thousands, of men who have the same feeling. The sport has in it the elements of adventure and activity, just the thing to alternate with the strain and confinement of professional or business life, a means of health and strength, of keeping enthusiasm and youthful freshness. Of course any ontdoor sport is useful in this direction, yet the quest of the study of Nature, in some of its departments, has special advantages for providing refreshing resource for the mind, as well as for the body. Bird study has a peculiar inducement in that it is seasonable the year round, and deals with living subjects, which are beautiful and of special fascination because of their power of flight. The gunner and the fisherman at the close of their short seasori-all too brief it seems-put a way their implements of the chase with regret, for it will be many long months before it will be time again to start out. But the ornithologist may go whenever his time permits, when the longing for the wild floods his soul.

If there were any question of the right of bird study to rank as a sport, and a leading one at that, a certain 


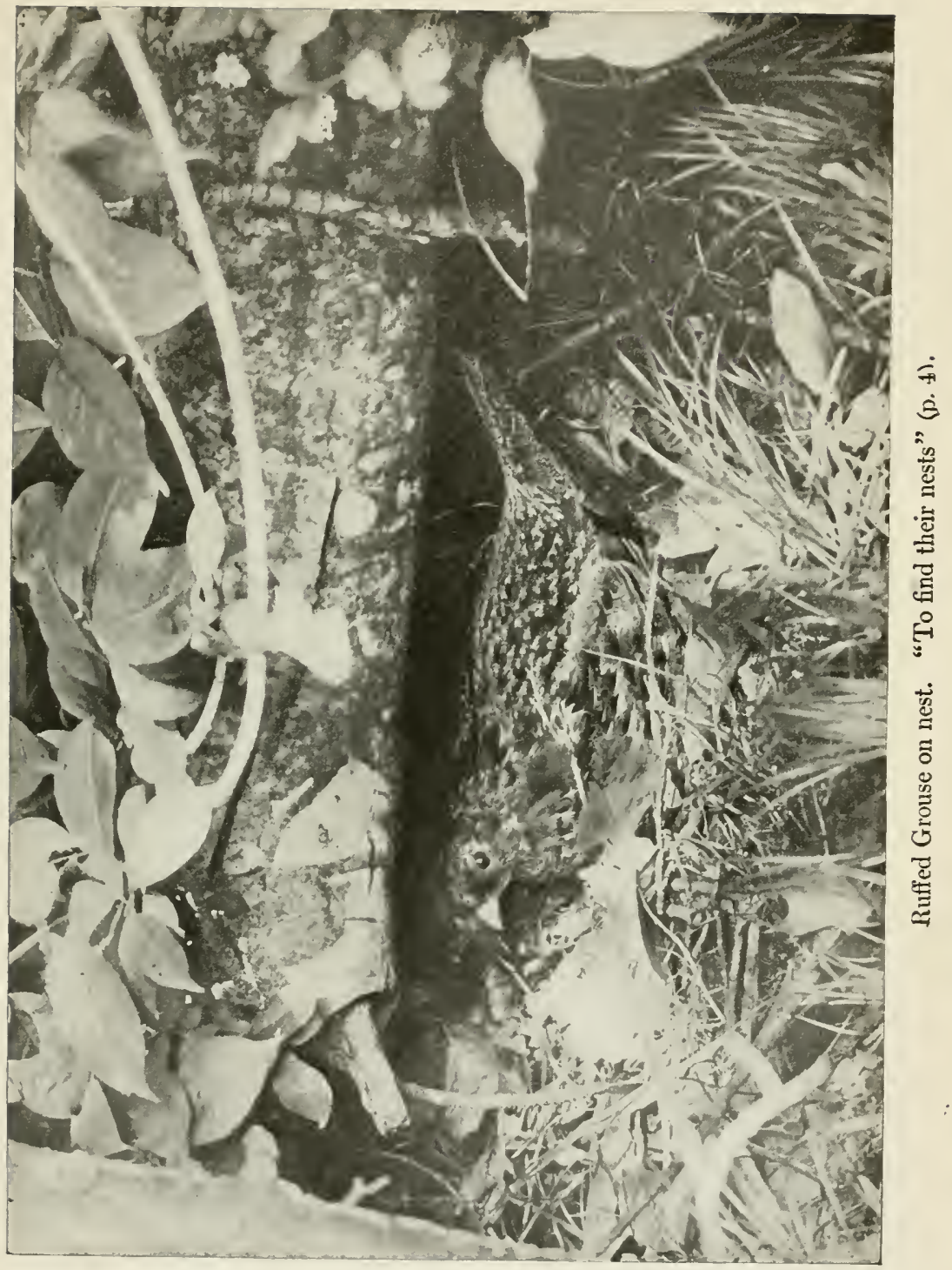




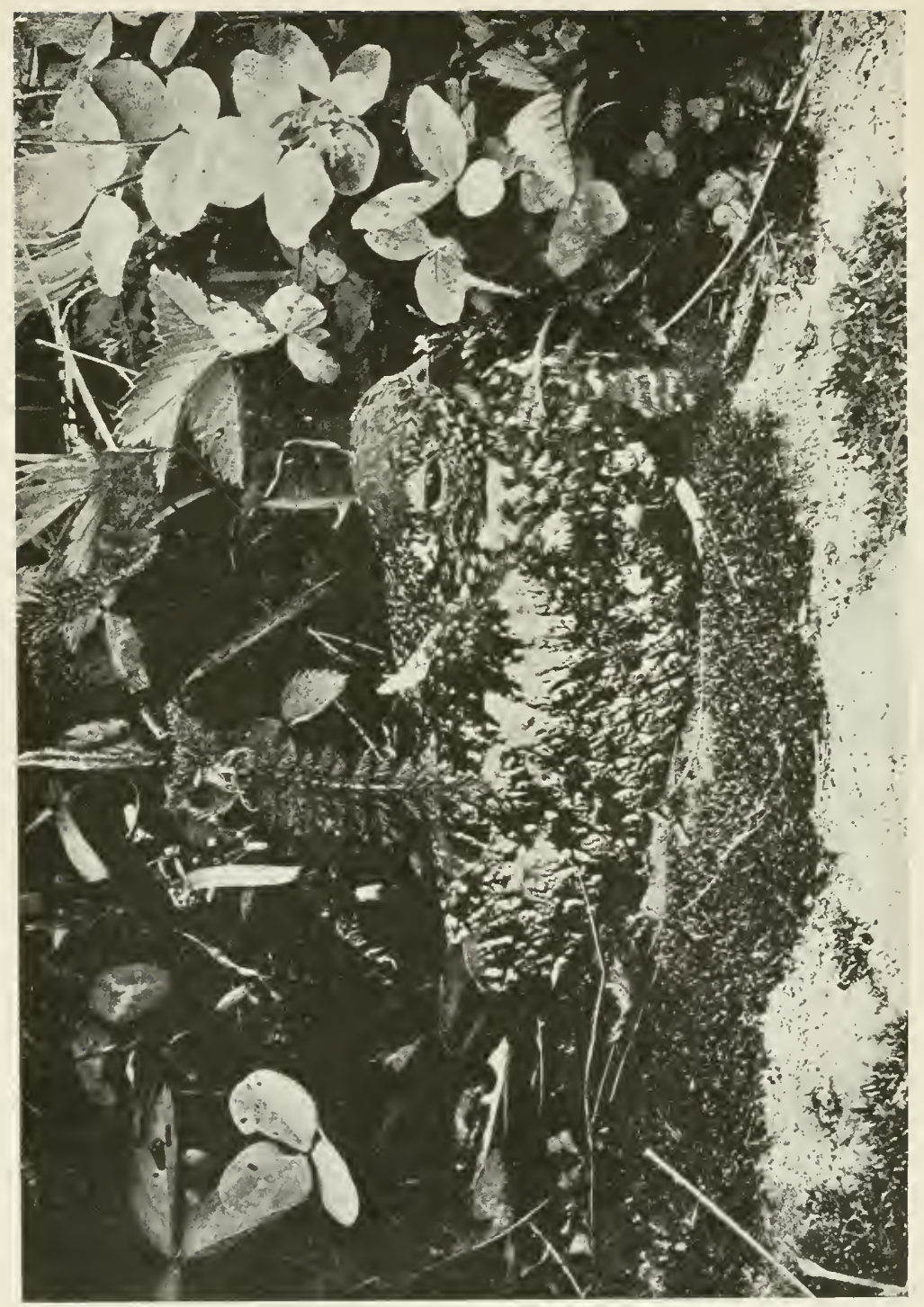




\section{THE APPEAL OF THE SPORT}

discovery, made not many years ago, banishes all possible doubt. This was the discovery that photography could be employed in bird study with splendid success. At once this gave to the bird student a weapon, an implement, putting him in the class of sportsmen. Nearly everyone now knows about this new thing which is, indeed, a sport by itself, "hunting with the camera." This is not confined to any one department of natural history, but is the capture upon a photographic plate of the image of any wild living creaturemammal, bird, fish, or even insect. Birds offer special inducements for this pursuit, as they are far more numerous than the wild mammals. Moreover, fish can seldom be photographed save in captivity, and insects are small and not popular.

Studying bird and animal life with the camera certainly is a splendid sport. It destroys no life, yet yields results far superior to those of gun and flesh-pot in our stage of civilization where we need not shoot to eat. How often nowadays one reads the admission of some hunter who comes close upon some fine game, that he wished he had had a camera instead of his gun. To shoot successfully with the camera requires far more skill, nerve, patience, brain-power, than with the gun, and yet is not hard enough to be impracticable. In the highest essentials of sport, to my mind, the camera stands far ahead of the gun.

My boy friend, of course, has caught the fever, and has a lightly-built long-focus camera, using a $4 \times 5$ inch 


\section{THE APPEAL OF THE SPORT}

plate, the very thing to begin with. I have one much like his except that mine has rather longer bellows, so as to allow the use of the single members of the doublet lens, and a larger size of lens at that, one intended for the next larger size of camera. This gives a larger image of a bird at a given distance, and is very useful with shy birds, or when one has to climb and photograph from tree to tree, or from branch to branch, and cannot get as near as is desirable to one's subject. Later Ned will probably get one like mine, and, if he succeeds well enough to warrant the outlay, a reflecting camera for photographing birds on the wing. These are costly and require a rapid and expensive lens. A 4x5 size, long-focus, is best for the purposes of most people, though a $5 \times 7$, if not of too heavy a make, has longer bellows, and admits of a larger lens.

This sport of bird study can be fitted to any person and any need. Pursued to the full it means adventure on land and water, hardihood, climbing trees or cliffs, danger, travel and exploration to the remotest parts of the earth, if one wish. But it can be limited to accessible local birds, the smaller birds of garden or field, in which even an invalid can take a world of comfort. A multitude of girls and women in these days are devoted to it. Though they do not usually venture, for instance, upon climbing lofty trees to inspect hawks' nests, like their brothers, many of them have done fine work and made valuable contributions to science. The girls in the high school, not far from the one which Ned 


\section{THE APPEAL OF THE SPORT}

attends, carry on a keen rivalry with the boys in this bird study sport, and not infrequently bear off the laurels, as in getting the first record of the season of some species, or some new one for the list, or in the prize photographic competitions in the magazines for the best pictures of wild birds or animals from life. So there is room in the sport for all, and whole families, parents and children, may all be bird-study sportsmen!

In writing this book I have in my heart a very warm place for the boys and young men who live in the country. Some think that life in the country is dull, and long to get upon city pavements. But if I can get them to catch my spirit, they will change their minds, and country life will take on new interest and joy. Though I was born and brought up in the city, the country was where I wanted to be. On every Saturday holiday, and on many an afternoon after school, I might have been seen making tracks for woods or waters. During spring and Christmas vacations I would take the train for Cape Cod. I never can get over the peculiar thill which I felt whenever I crossed the boundary of a "Cape" town and felt that I was actually on Cape Cod. Somehow it seemed like sacred ground, a land of bliss unspeakable. I was under a spell of excitement, of exhilaration. It was country, bird country-"God's country," as they say out West.

A country town appeals to me as a sort of gold mine. Those wooded hills are treasure houses, these swamps 


\section{THE APPEAL OF THE SPORT}

are more luscious than marsh mallows, those field produce harvests of rarities. I am eager to start forth and ramble on, to seize and conquer this rich province with mind and eye, to make it mine. Nothing do I care to own it, as other men do, and pay taxes, if they will but tolerate my roamings, letting me visit, watch, study, photograph its glorious wild citizens. Really I pity the person who cannot enjoy the country, who has so few resources of mind as to need to be amused by the passing throng, who must forever get, in order to be happy, and has little or nothing to give.

I want to start out many healthy boys, girls and youth on this enticing combination of sport and study to enlarge their lives, and make them happier and more contented with their lot in life. So I shall try, with the help of my lively young enthusiast and companion, to show that ornithology, or bird study, can be made a live thing, a sport, a fine pursuit for any active person, as it has surely proved to be for a growing boy like Ned. Sometimes, to inspire and educate him, I take him off with me to some wild and distant region, to camp out and rough it, and develop his manliness and selfreliance. I shall proceed to tell what he and I, or I alone, find in quest of birds in an ordinary inland country town, not a remarkable one, but an average one, any country town, indeed, in the Eastern or Middle United States, just such a town, very likely, as the one in which you, Reader, dwell, or spend your vacation. I shall try to tell, in the main, what birds you will be 


\section{THE APPEAL OF THE SPOR'T}

likely to find in such a town, how we found them, and what fun we had in doing so. You had better have a complete text-book with descriptions of birds and keys to identify them, such as Chapman's, or Hoffmann's Handbook, and also a field or opera glass, the more powerful the better. Later you can buy a camera, if the sport appeals to you.

Most of the birds here told about are found also in other parts of the country and in Canada, and the general idea of the book will apply as well there, for the sport of bird study is not limited to any narrow boundaries.

It is a good idea for all who study birds to know something of their classification, the principal groups and families into which bird species are divided. There are not so very many of these, and they are very distinct one from another, and one can easily carry the whole scheme in mind. In coming upon an unfamiliar specimen, it is pleasant to be able, from its general appearance or habits, to recognize at once to what family it belongs. All there is to do, then, is to take the Handbook and find which of several species it is. Most of them, indeed, one will probably know alreadythe thrushes, warblers, swallows, finches, woodpeckers, hawks, grouse, gulls, and so on. In the chapters following I tell about the different groups of birds in their order of classification, except that the swimming and wading birds are transferred, for convenience, from first to last. It will be a good idea to learn the scheme 


\section{THE APPEAL OF THE SPOR'T}

of classification, which is given elsewhere in this book, and then, when afield, see what pleasure it gives to be able to instantly assign each bird as it appears to its proper family apartment in the big bird-house of Science. One feels that he has a grasp upon the subject and knows just about what to expect. Ned is already an expert in this.

But now here he comes running back to remind me that I forgot to return his precious jack-knife, so we must stop talking about him. 


\section{CHAP'TER II}

HUNTING GAME BIRDS WITH THE CAMERA

\section{(Upland Game Birds)}

LL the fall the gunners were at it. The weather A was mostly fine, and the guns seemed to be barking in all directions nearly every day. Birds were plenty, tempting some hunters to kill more than the law allowed, and the game warden caught some of them red-handed. It certainly seemed as if there would be no birds left by the time that the law went on again, the first of December.

So I was pleased enough, during my winter rambles, to flush good numbers of the Ruffed Grouse on the woody hillsides and in the swampy woods, and, when the first mild days of early March arrived, to find that there had returned to their old haunts in the alder swamps quite a number of the Woodcock, generally recognized as the king of the game birds. With the coming of freezing weather the Woodcock had left us for a milder climate, where things were made warm for them by gunners all winter long. It was a worfer that any of them had lived to come back.

Game birds are ranked by sportsmen not so much by their size as by the degree in which they "lie to the 


\section{HUNTING BIRDS WITH CAMERA}

dog." The Ruffed Grouse is all too apt to run away as the hunting dog approaches, and flush from a distance. The IVilson's Snipe of the meadows lies closely enough some days, but on others sneaks off, and flies wildly to safety. The Bob-white, or Quail, is a fine bird to hunt with the dog. Sometimes I have had almost to kick them up before they would fly. But the closest squatter of them all is Sir Woodcock, and he is king without a rival, with our friend Bob White, Esquire, as a close second. These are the four real game birds of eastern districts and the subjects of this chapter. We shall see what sort of game they make for hunting with the camera.

In this hunting, as well as in the other, Woodcock is king. Though he does not seem to be particularly a proud bird, yet he does have great confidence in himself, in his ability to escape the prying eyes of enemies, and rightly so, for his colors and markings are so closely like those of his surroundings in the woods and swamps that he can defy most eyes to detect him. Naturalists call this "protective coloration," and a splendid protection it is. So the Woodcock learns that all he has to do, ordinarily, to be safe, is just to keep still, and well has he learned the lesson.

One April day Ned and I were following along a brook which flows through a pasture and is fringed with alders. "Hullo," said I, "I wonder what sort of a last year's nest that is on that low bush over there!" So I went over to see, and stooping over to examine it, 


\section{HUNTING BIRDS WI'TH CAMERA}

with my face not more than a yard from the ground, something happened so suddenly that I almost fell over backwards. A Woodcock flushed from right underneath my nose and almost hit me in the face. I gave an exclamation of surprise, and of joy too, for surely this must be the nest. Ned saw the bird go off twittering and alight in the swamp beyond. He hurried up to see the eggs, for it was nesting time, and we were hunting ior Woodcocks' nests. No! I could hardly credit my senses. No nest there, and the bird so tame? But it was even so. More disappointed hunters it would be hard to find. The other bird of the pair, meanwhile, had been lying close, not ten yards away, and in our search for the nest we finally flushed it too, though we did not get quite so near.

There were various other alder swamps in the neighborhood, where Woodcock lrad been seen, and one day I induced a resident hunter, who was Woodcock-wise, to bring his $\operatorname{dog}$ for a tramp with me, to try to find a nest. The dog did not lead us to anything, but his owner happened to see some eggshells lying on the ground, the remains of three Woodcock's eggs which had been eaten by some animal, for the prints of sharp teetl were in the shells. The place was a bushy tract at the edge of a meadow, and the nest was a small hollow on a grassy hummock beside a low alder.

But back along the same brook where we flushed the birds someone else had better luck. A young man came in to cut alders for bean poles. After chopping 


\section{HUNTING BIRDS WITH CAMERA}

nearly an hour near one place, all of a sudden a brown bird darted up from almost beneath his feet, and there lay four handsome drab eggs, spotted with lilac. I had advertised a reward for a Woodcock's nest, so early the next morning the youth came and told me, and I went with him immediately in a fever of excitement, for in all my travels I had never yet found a Woodcock's nest.

The alders grew in clumps about twenty feet high in the part of the swamp to which my guide took me. Presently he stopped to look. "She's on the nest," he said. "Don't show me," I exclaimed, "let me make her out." I had to look very sharply, but quite soon I spied her, about fifteen yards away. It was a wonderful protective blending of colors. The varying shades of rather bright browns and yellows of the dead leaves almost perfectly corresponded with the browns in the plumage of the bird.

The spot she had chosen was on the mound around the base of one of the innumerable clumps of alders. There lay the bird among the dead leaves, without any protection of undergrowth, right out boldly in the open, relying solely upon the blending of her color and form. with the surroundings. Then I approached nearer, more cautiousiy than I needed to have done, for I could hardly bring myself to believe that she would sit there if a man came striding up close to her, so plainly was she now visible to me. Yet she stirred not; her large, soft, brown eyes, the most conspicuous part of her, did not move or wink. 


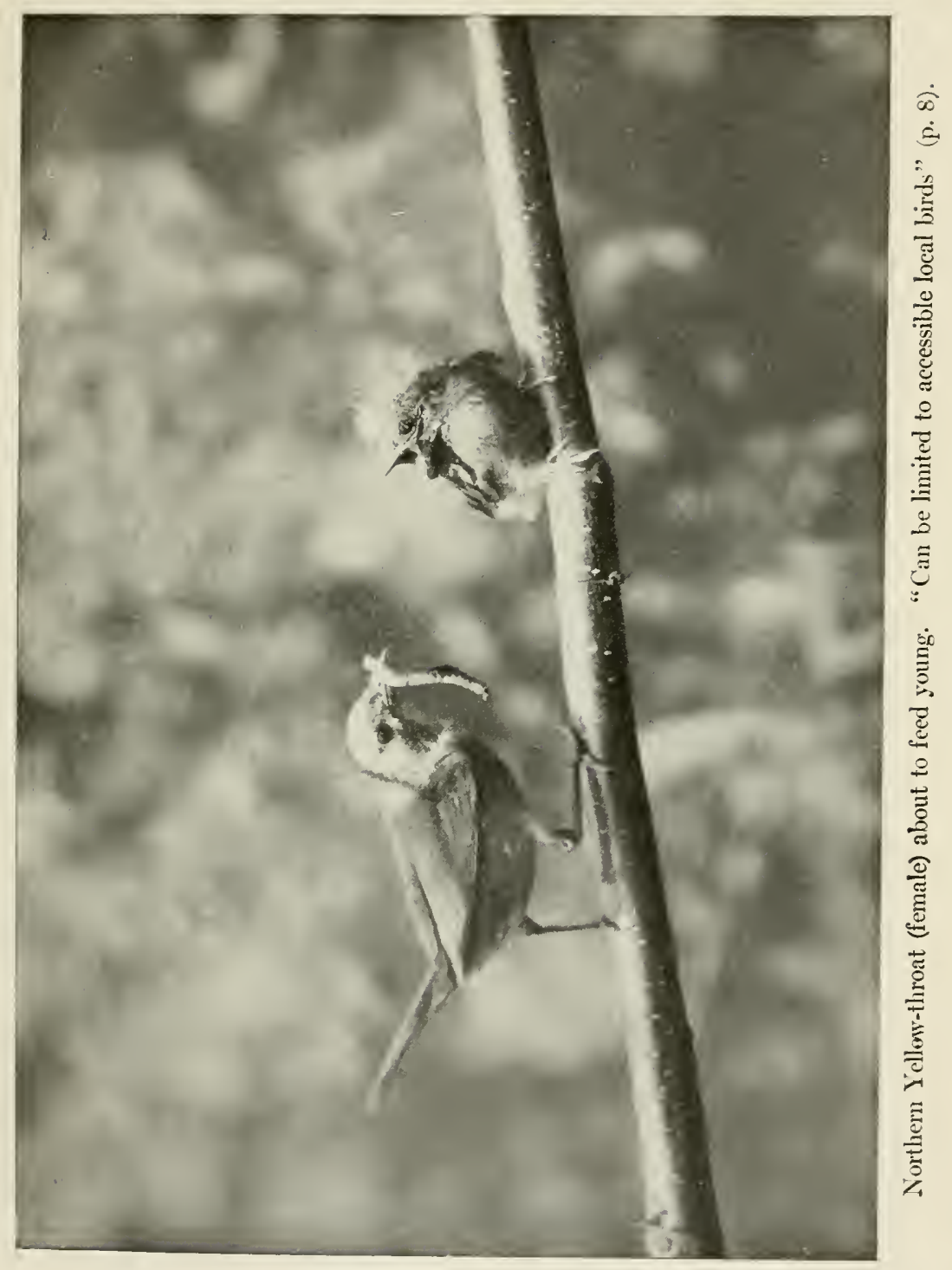




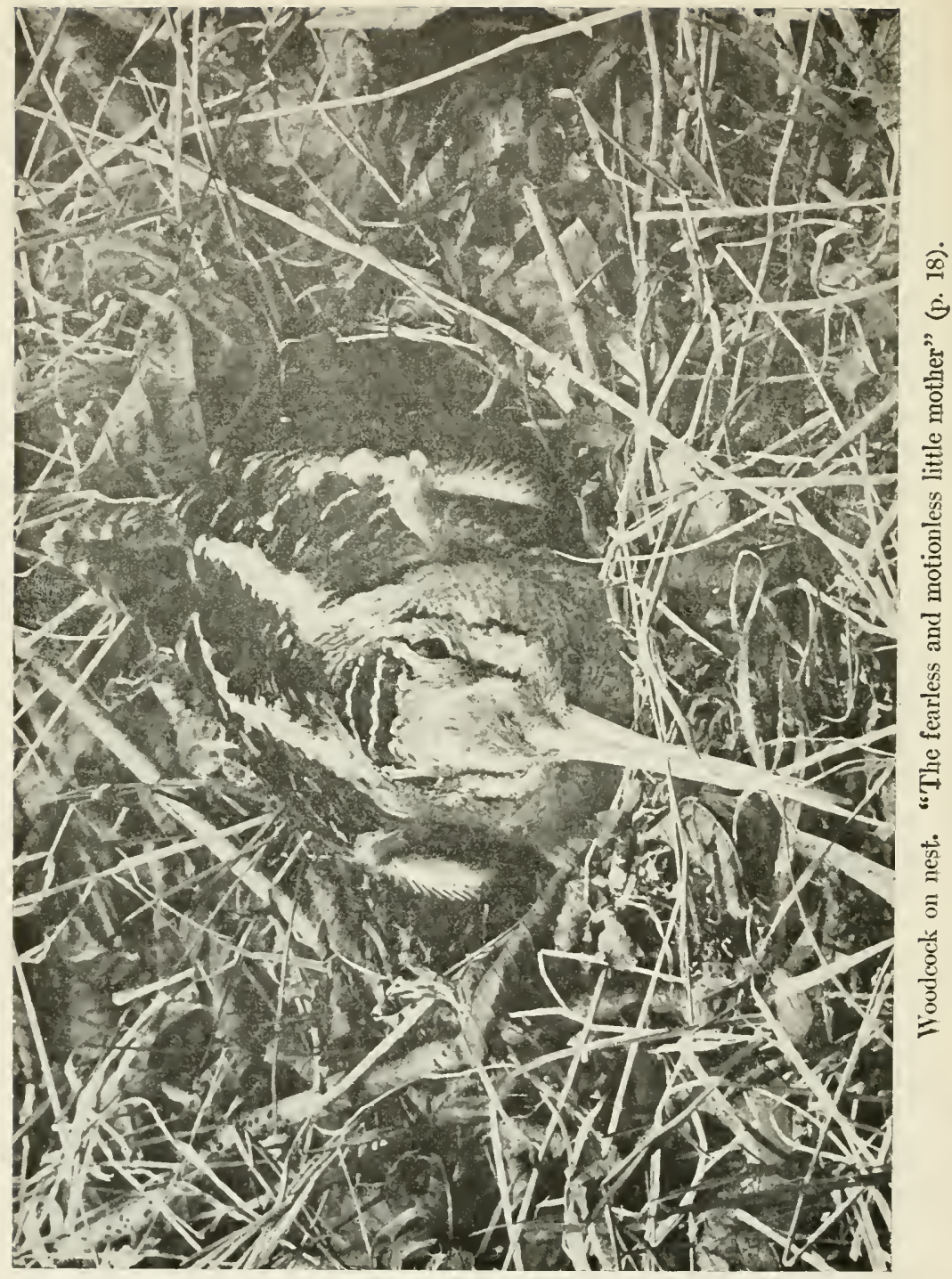




\section{HUNTING BIRDS WITH CAMERA}

Taking from my pocket a crisp two-dollar bill, I bestowed it upon the modest youth, who hardly thought that he could rightfully earn so easily a day's wages. Then he departed, leaving me alone with the bird. The day was April 18th, one of the last cold days of a vigorous and hard-dying winter. With the mercury below forty degrees, dark and cloudy, a cold wind raging, and occasional snow squalls, it might not seem a very favorable time for photographing birds. But I dared not wait. By to-morrow she might easily have hatched and led away her nimble young. To-night a wildcat, fox, raccoon, or skunk might discover her and end my hopes and plans. So I went right to work. Dark as it was, there was time enough for exposures, for this bird would keep as still as the towering hills before me.

Setting up the camera on the tripod, I went to work taking pictures of her, at first from a little distance, so as to make sure of some result, in case she should fly, but presently as near as anyone could wish, the lens being within a yard of her. During the two hours I was at it, the only motion she made was to wink once when a pellet of sleet struck her on her unprotected eyeball.

By this time I had taken nine pictures, from different positions, and I might have continued all day, had not my foot cracked a dry twig close to her head. This was too much even for her steady nerves, and away she darted, not fluttering off as though wounded, like the 


\section{HUNTING BIRDS WITH CAMERA}

Wilson's Snipe when flushed from the nest, but with quick, direct flight.

This gave me a chance to examine and photograph the eggs which lay in a simple hollow in the dead leaves. Then I withdrew to a distance and hid behind a bush to watch for her return. Just then it began to snow hard, and soon the ground was white, though the crystals melted on the warm eggs. Fearing that my presence might be keeping her away, I went off and explored a neighboring wooded hill, where I found a hawk's nest. The Woodcock had not returned in one hour, nor in two, but at the end of four hours she was brooding again, as tame as ever.

Of course at an early opportunity I had to bring Ned to see the wonderful sight. After taking some more pictures, we sat on a rock only six feet away to eat our lunch, watching with keen interest the fearless and motionless little mother. Never had we seen a bird lie so splendidly to dog, man, camera, or anything else. To our minds the title royal was fairly earned, and Woodcock was certainly king:

We had, however, one final and severe test for herto try to make her stand up to be photographed. After getting the camera aimed and focused, and being all ready, with one hand I presented to her the end of a short stick. She did not move when it touched her, nor even when I pried her up off the eggs and finally pushed her over on to one side. She would not stand up for me, but at last, crouching as low as possible, she 


\section{HUNTING BIRDS WITH CAMERA}

gave a sudden spring and went up like a glass ball from a trap. Even if I had tried to make the exposure, I know that I should have been far too slow. I have no doubt but that we could have handled her, had we tried to do so. Then I set the camera, attached a thread to the shutter, and hid behind a bush at a distance, to get a picture of her as she came back, meanwhile letting Ned go home. There I sat with eyes glued to that spot in the leaves for four mortal hours. The bird did not appear, the sun went down, and I had to give it up.

Of course the eggs would be chilled and spoiled, and I wondered how long she would sit on them. I made a few more calls on Madam, and then neglected her until the second day of May. Four neatly split shells lay in the nest. The hardy eggs had hatched after all, and four little Woodcocks were somewhere following their devoted mother and learning to bore for worms along the soft margin of the brook.

That same year, late in July, one of my other boy friends caught a young Woodcock as he returned from fishing and was walking along the railroad track. The bird flew up from the road-bed and alighted in the grass, where it hid and allowed him to catch it. It was fully fledged, but not yet very strong on the wing. Ned and I kept it for a month, and had very interesting times with it. We kept it in a wire chicken run, and fed to it as many as 175 earth worms a day. It soon got so that it would run up and take worms from our hands, and sometimes it would even try to swallow my 


\section{HUNTING BIRDS WITH CAMERA}

finger, mistaking it for a nice fat worm. It would grasp a worm with the end of its long bill, using the tip of the upper mandible independently of the rest of the bill, like a thumb, and then gulp the worm down. Most of the worms were put in a pan of moist earth, through which they burrowed to the bottom. This was at night, and in the morning we would find the earth completely perforated with round holes where the bird had bored for its game. It was seldom that a single worm could long escape.

Sometimes I would take the bird out for exercise and picture-making, tying a thread to its leg to prevent it from flying away. It would run about the lawn erecting its pretty tail, which it spread out pompously after the manner of a turkey cock. In like manner it would drink or dabble along the margin of the river, and it was a sight to watch it bore for worms in the soft mud of the sink drain. Finally after a month's captivity, I let it go, and the last I saw of it, it was trotting off under the bushes on the river's brink. We all thought everything of "Woodie," whose only fault, according to Ned, was its enormous appetite, that fairly tired him out digging worms to appease it.

But he had a harder task yet in store. Time flew along, like the birds, and it was April again. One day a young man brought me an adult Woodcock, which he had caught by the roadside. It had hurt its wing against a telegraph wire and could no longer fly. It could eat, however, and we soon found that it was no 


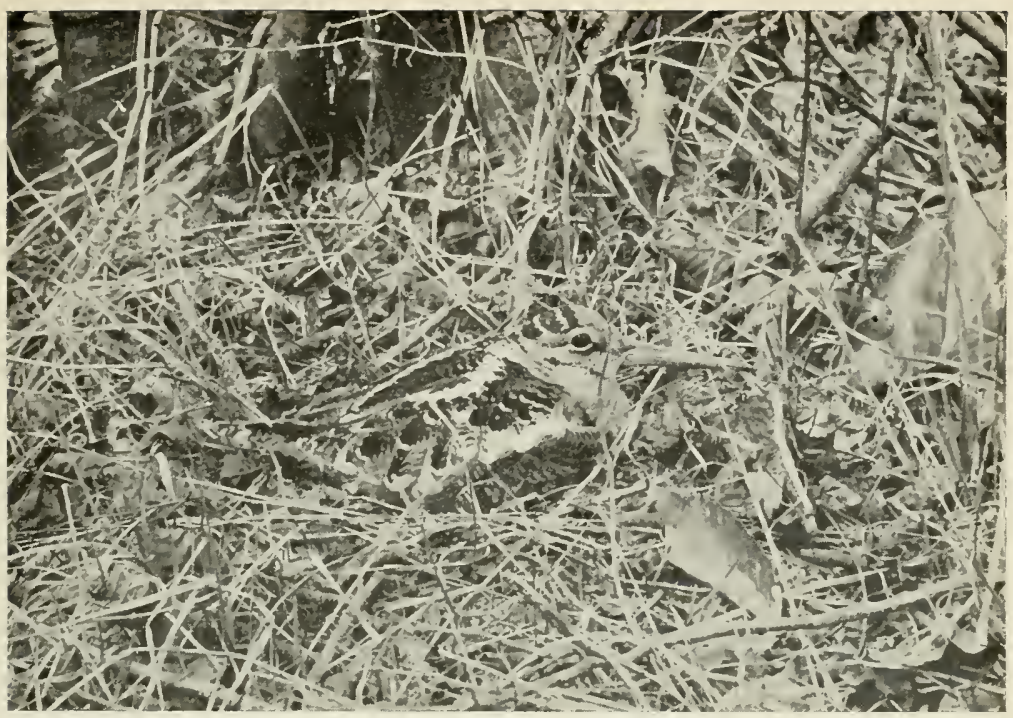

Woodcock on nest, showing surroundings. "Don't show me . . . let me make her out" (p. 16).

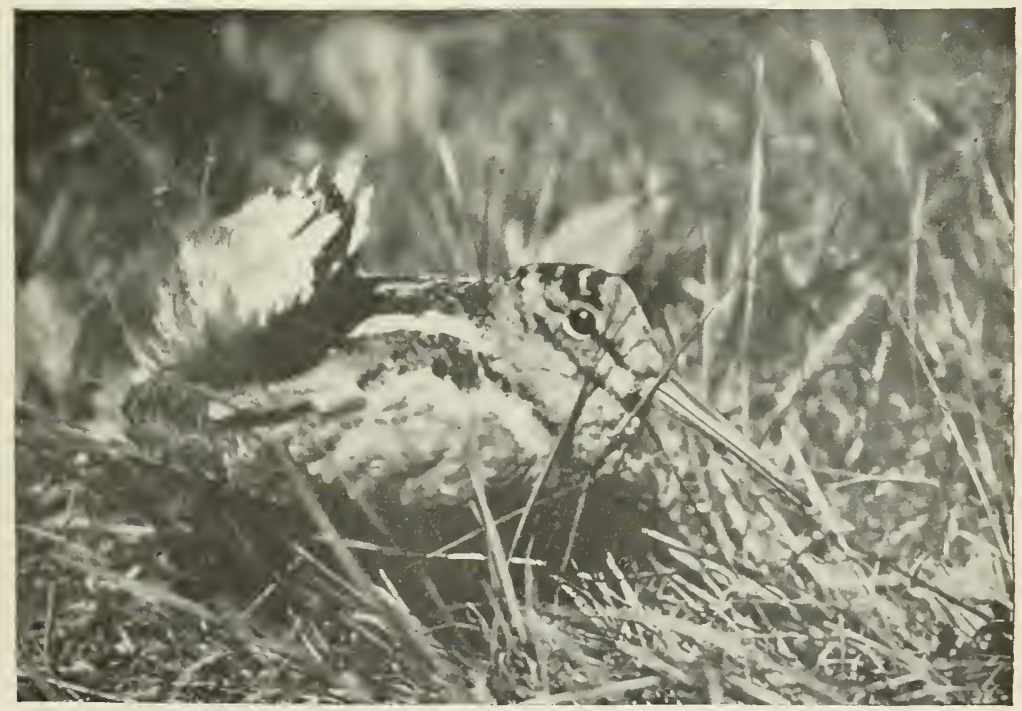

Young Woodcock. "Frecting its pretty tail" (p. 20). 


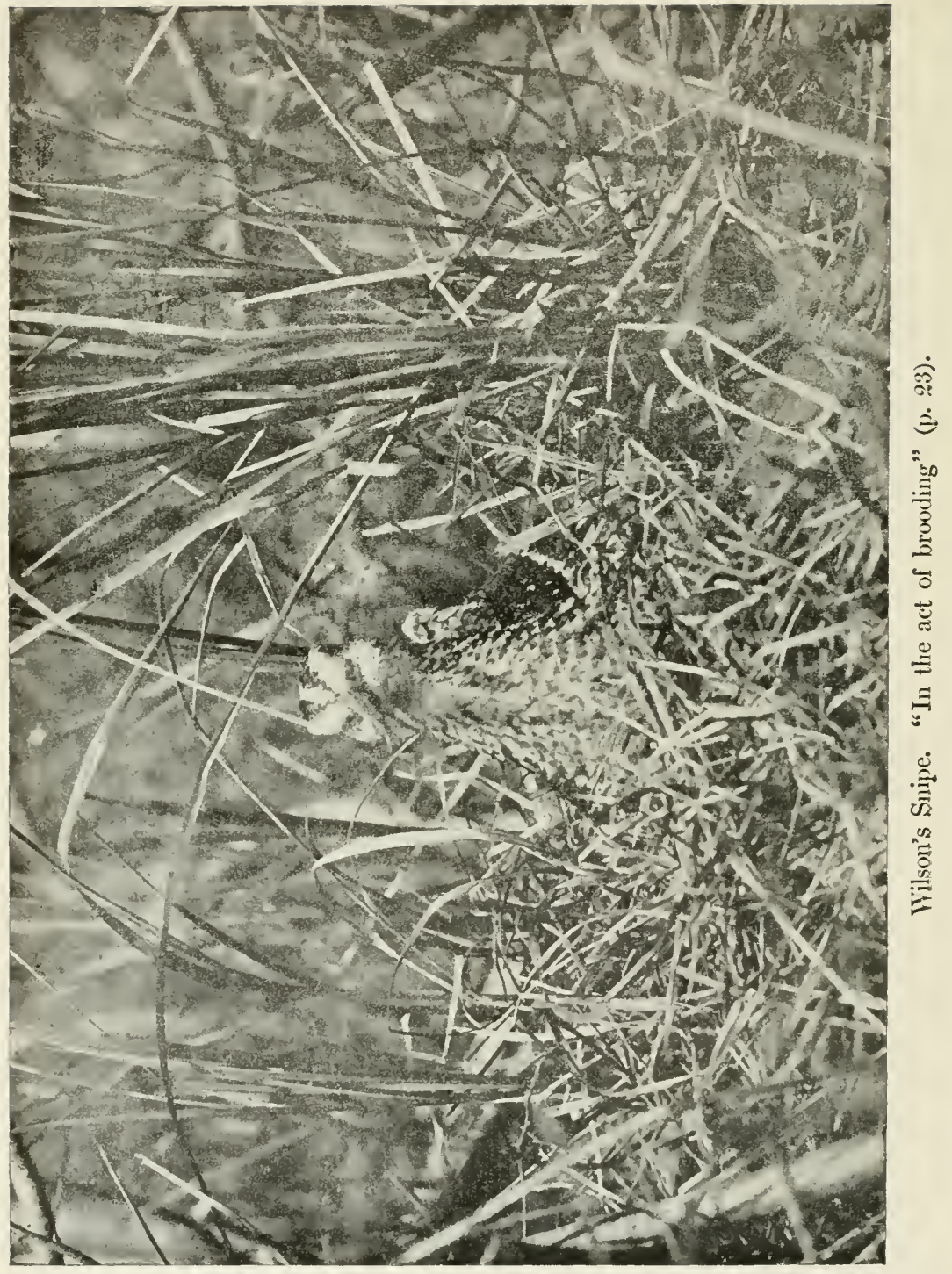




\section{HUNTING BIRDS WITH CAMERA}

play to dig worms for it so early in the season-a cold, backward spring, too. Ned had not much time after school, and I was busy. One day I dug for over an hour and did not find worms enough for half a day's rations. Later in the day, as I passed a store in the town, I saw a boy standing idle, and an idea came to me. "Don't you want to earn some money?" I asked him. "Yes, sir," he replied. "All right," said I, "if you will dig me some worms for my pet Woodcock I'll give you ten cents a pound for them." That night he brought a tomato can full and said he would get more. The news spread rapidly among the boys that a sort of gold mine had been discovered. There was a regular procession of boys with worms, and I was kept busy weighing worms and finding change for my "worm brigade," as I called them.

None were wasted, for the Woodcock was a marvelous eater. When it first came it weighed five ounces. Hearty eating soon brought it up to six and one-half, and then it dropped to a good full six, where it remained for months, until it was drowned one night in a terrific thunder shower. I weighed the food carefully, and found that it averaged about ten ounces of worms every twenty-four hours. Seldom did it eat less than eight ounces, often eleven, and once, when I weighed the food, it disposed of an even twelve, twice its own weight. "Ned," I said, "how much do you weigh?" "A nundred and ten," he replied.

"Well, if you were as big an eater as the Woodcock, 


\section{HUNTING BIRDS WITH CAMERA}

it would take about two hundred pounds of meat a day to keep you. Do you suppose your father would support you and send you to college if you ate forty dollars' worth of meat a day?" Ned thought that his fond Papa would have to send him to work instead of to college, so it is well that his appetite is not quite so tremendous.

The game bird which is the nearest relative of the Woodcock is the Wilson's Snipe. Not many people except sportsmen know it at all, but the trouble is that a good many are as afraid as cats of getting their feet wet. But it never in the world will hurt a healthy person, if one only keeps warm by exercising and takes off the wet things before sitting down. Often I have walked home through the town with the rater squeaking in my boots like a suction pump, but I never caught cold that way. But with long rubber boots, unless we fall into some bog hole, we can probably keep dry, and vigorous tramping in boggy meadows in April or early May, or in September or October, can probably add the Snipe to our acquaintance and our bird list. We shall see its rapid, irregular flight, and hear its curious note- "escape," it seems to say, which it proceeds to do admirably, unless the intruder be a gunner and a good shot besides! Often have I chuckled to see the would-be snipe shooter's bang-bang, miss-miss!

The bird goes mostly north of the United States to breed, though a few do so along the northern border. I have found just one nest in my life thus far, up in the 


\section{HUNTING BIRDS WITH CAMERA}

Magdalen Islands, in the Gulf of St. Lawrence. The male seems to give warning to his brooding mate when an intruder approaches the nest, and the pair dart around very swiftly up in the air, making a humming with their wings and sharp scolding notes. One of my bright-eyed young friends hid and watched a female until she alighted near her nest, which he then found, and we all had chances to see her go fluttering up as though desperately wounded. She was very tame in returning, and by setting the camera on the ground, focused on the nest, and pulling the thread, I secured several good pictures of her in the act of brooding her four dark mottled eggs.

Previous to the severe winter of 1903-4, Bob-white was an abundant bird in our locality. Sitting on my piazza, I could hear ringing calls issuing from the outlying clover fields, as the proud little roosters challenged one another from their observatories on stone wall or rail fence. Sometimes, especially when driving, I have passed quite close to our noisy little friend on the fence, but he is off in a hurry, if one stops to look at him. In the autumn I have followed up coveys to see what they would do. Once, in September, I saw a number of them on a stone wall. They flew down as I drove by, into some bushes close at hand, and I hitched the horse and went after them. Standing on the wall, I studied over the ground under the bushes very carefully, but could not make out a single bird. But when I tossed in a big stone, up they all went like rockets, nearly 


\section{HUNTING BIRDS WITH CAMERA}

twenty of them, right from the very place I had so carefully examined.

How well protected they are by their colors $\mathrm{I}$ once had a fine chance to see. A single bird flushed before the hunting dogs, and took to a patch of scrub pines. I went in to look for it, and, as I was standing where the shade was dense, but the ground clear of undergrowth, I happened to see it lying flat on the ground on the smooth carpet of pine needles only two or three steps from me. Before I had time to get my camera ready it realized that it was discovered and flew off. So I got no picture, and, indeed, had never shot quail with the camera. But opportunities came, at length. Mrs. Robert White, like the old woman of shoe-residence fame, usually has a great many children. She raises a big batch of them in June, and then often tries it again in July and August. She is apt to nest in hay fields, and the mowing-machine discovers this second nesting. So one day, late in July, a farmer told me that he had found a nest. Sure enough, in the corner of his field by the stone wall was a nest with sixteen eggs, in a clump of grass which the kind man had left to protect them. It was easy enough to photograph the eggs, but the mother bird was afraid of the camera, so I had to take it away without getting her picture. I made another visit very soon with $\mathrm{Ned}$, and was just in the nick of time, for fourteen of the sixteen eggs had hatched, and the cunning little things which looked for all the world like little brown-leghorn chickens, only 


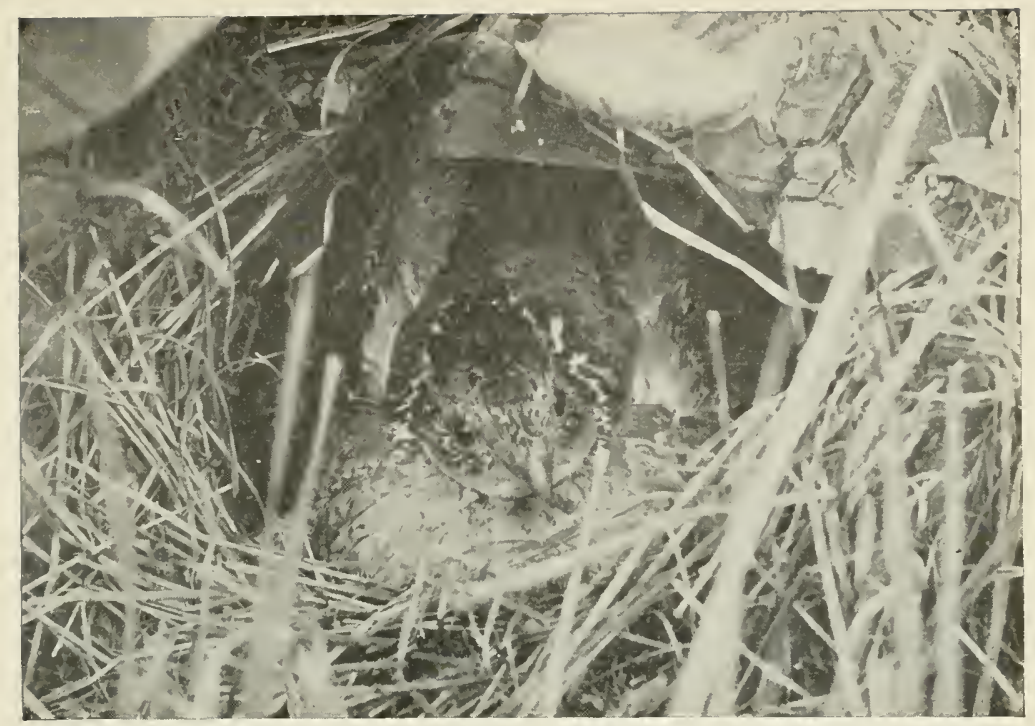

Bob-White on nest. "Could stroke her on the back" (p. \&5).

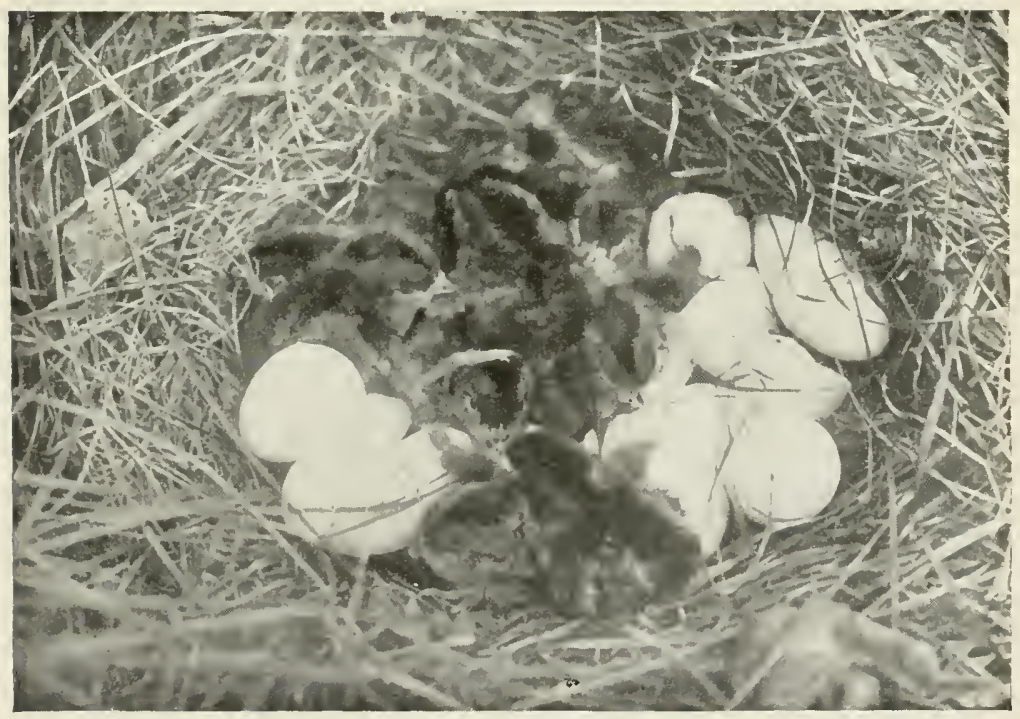

Nest and brood of Quail. "Like little brown leghorn chickens” (p. 2.4). 


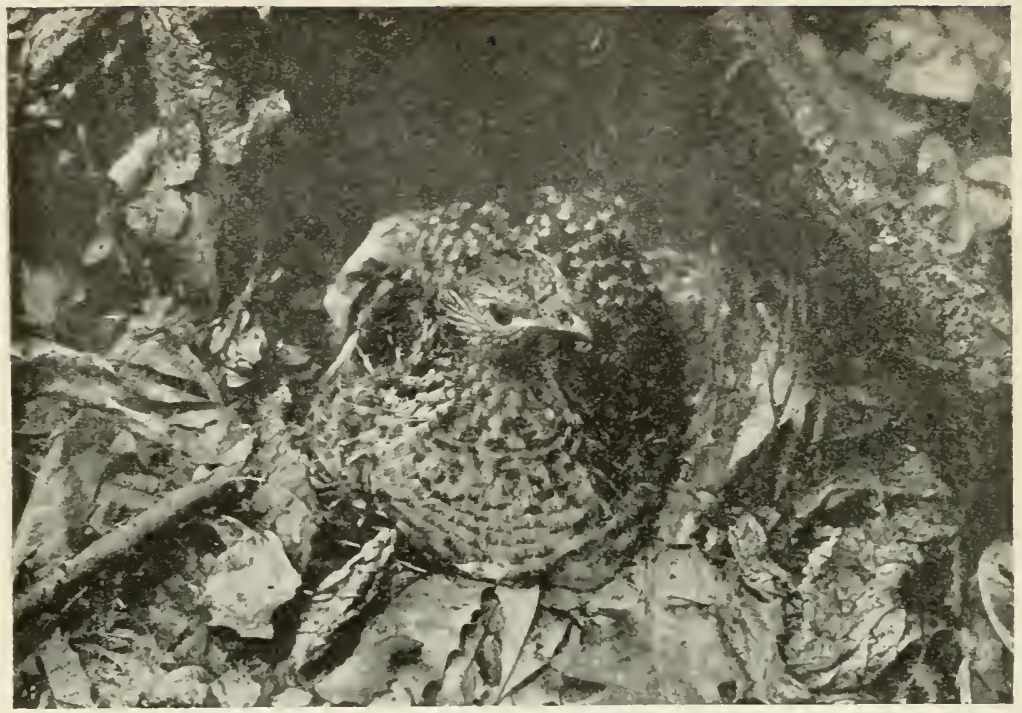

Ruffed Grouse incubating. Secured by leaving the camera set over night (p. 30).

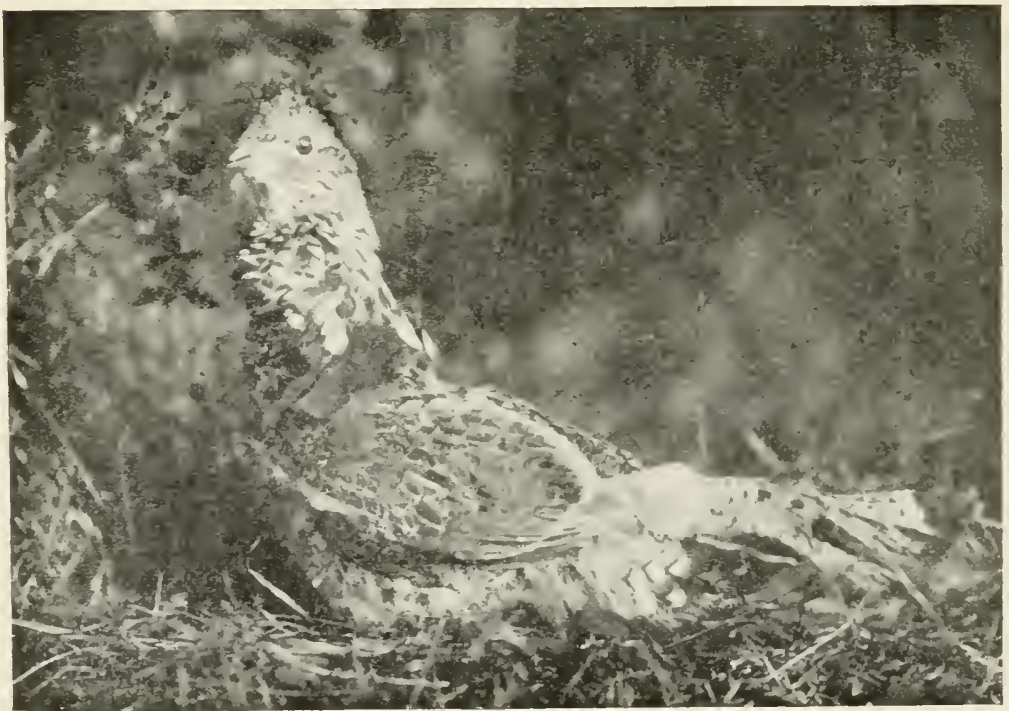

Ruffed Grouse in confinement. "Saying, 'quit, quit,' like a turkey" (p. 31). 


\section{HUNTING BIRDS WITH CAMERA}

about half their size, were all in the nest, just dried off ready to leave, as they always do very shortly after hatching. The mother was brooding them, and she fluttered off, while the young scrambled out of the nest in an instant and hid in the grass. Between us both we managed to find ten, which we put back in the nest, where I photographed them and the egg shells. Each one of the eggs had the larger end neatly split off to let out the chick. The membrane held the piece like a lid, and in most cases it had shut down again so neatly that one would hardly notice but that the eggs were round and full as ever of young quail. As soon as I went away the anxious mother, who had been whining at us from the wall, sneaked back to her chicks and doubtless led them away at once. It was disappointing that it was a dark showery day, so that I could not try for a snapshot at the family as they left their happy home for the wide, wide world.

"My, but wasn't it great luck!" About a week later another farmer mowed by a nest and found it. This one was not half a mile from the other, right beside a much-traveled road, under the end of a pile of fence rails. This bird was very different in disposition from the other. She was so tame that Ned and I could stroke her on the back without making her leave her eggs, so accustomed had she become to seeing people, who were constantly passing so near that they surely would have stepped on her, had it not been for the protecting rails. She was in plain sight now, without 


\section{HUNTING BIRDS WITH CAMERA}

the long grass, and yet no one else discovered her. I set up the camera as near as I could wish, and photographed her without the least trouble. Then Ned poked her off the nest. I got her picture as she was leaving, out in the grass, where he "shooed" her to make her stand still, before she flew. Having to drive past on the following day in the evening, I stopped my buggy within a yard of her and watched her awhile. As usual, she never moved or winked. The next day eleven split shells told the story of the birth of eleven little Bobby-whites to roam the grain fields and pastures of their beautiful valley.

I had now secured photographs from wild life of three of the four important game birds, and was eager now to conquer the remaining one, the Ruffed Grouse. In past years I had often found their nests. A favorite location is in a pine grove, under some little bush or sprout. One day, some ten years before this, I had found two in one tract of pines, within half an hour. Another favorable place is swampy woods, beside a fallen $\log$ or underbrush, as well as in drier woodland. Confident of success, through past experience, the following spring, in May, I began the hunt for a nest in woods where the birds were common. It is largely a matter of chance-though of persistence, too-to walk close to the brooding bird, practically invisible by her protective coloration, and flush her from her eggs. What a tremendous whirring she makes as she leaves! Somehow luck was plainly against me at the first. 26 


\section{HUNTING BIRDS WITH CAMERA}

Day after day I had ranged the woods for miles and miles, but I did not happen upon just the right spot. But at length, while I was thus hunting, I met a man burning brush, who told me of an Indian hunter who recently, while guiding a surveying party, had found two "Partridge" nests. That evening I saw the Indian, and arranged to have him show me his finds.

Two days later, in the morning, we started up a trail over a very mountainous tract. For nearly two miles it followed a rocky ravine by a roaring brook. A rattlesnake sprung his wavering alarm, but I was too eager in the quest to care that day for snake trophies. Three miles back from the road we reached the neighborhood of the nests. One was in a swampy hollow along the line of the surveyor's' blazings, beside a stump. We finally found it, after quite a search, but some wild animal had eaten the eggs and the shells were scattered about. The other was a little further on, beside the trail we had been following. The bird was on the nest, directly at the base of a clump of chestnut sprouts. Despite her solitude, or else because of it, she was one of the wary sort and ran off, trailing her wings, before I could get with the camera within fifteen feet of her. She had twelve eggrs.

Leaving the vicinity for a time, when I returned she was not on, though the eggs were warm. Then I hid and watched. In half an hour she came walking back, with head erect, jerking her tail. After waiting a quarter of an hour for her to get composed, again I 


\section{HUNTING BIRDS WITH CAMERA}

tried to approach, but she ran the instant she saw me coming. Evidently this method was hopeless, so I rigged the camera up in some bushes in front of the nest, covering it with leaves. Then came a tedious wait in hiding, with thread attached to the shutter, but no sign of the bird. So I extendod my line of thread away off in the woods, went off for an hour, and then pulled at a venture. This time the bird was at home, having become used to the camera. It was now late afternoon, so I had to return home, after fixing an imitation of the camera to keep the bird accustomed to the instrument. The plate proved to be hopelessly under-exposed, though the exposure was for one second, with full aperture, but with a single lens of the doublet.

The next two days brought pouring rain, but I tried it again on Memorial Day, arising at 4 A. M., as I had to be back at noon for public exercises. The bird skulked off again, so I set the camera as before, but she had not returned in over three hours. It was then eleven o'clock. I left the camera set, ran the three miles down the trail in twenty-eight minutes, jumped into the buggy, and barely was in time for my appointment. The exercises were over by the middle of the afternoon, and I hustled back up the mountain, reaching the nest at 4.15. The bird was on, and I pulled the thread, the shutter set for its longest movement, about a second and a half, and with the doublet lens, giving four times the illumination of the single lens. 


\section{HUNTING BIRDS WITH CAMERA}

By 4.30 I had the plate changed and was in hiding. At 5.05 the hen returned to her eggs. When she was still I was about to pull the thread when a wonderful thing happened. Just in the rear of the sprouts under which she was sitting I caught sight of some large creature, apparently sneaking up to kill her. At first, through the foliage, I took it to be a hog or dog. When it got almost to her, I saw it was a big bird, all bristled up, a turkey gobbler, I thought. Suddenly it made a rush right into the nest. Involuntarily I almost shouted and leaped to my feet to rush out and save the eggs from vandalism, when it suddenly dawned upon me that it was the male bird making love in his own way. The hen was too quick for him. She flushed like a projectile from a gun and was gone, leaving her admirer beside the nest. For fully a minute he stood there, perfectly still, the very picture of pomposity. His tail was erected and spread to its widest extent, as was the glorious black ruff on his neck. The head was raised and the wings drooped. After thus duly surveying the situation he finally strutted proudly off into the bushes. Meanwhile I was undergoing counter-blasts of excitement, delighted with the scene, and chagrined that he was just out of the field and focus for which the camera was set. What a picture that would have been!

The hen returned to her brooding within five minutes, and I made the exposure. But somewhere in the bushes the old rooster was watching, and again, in 


\section{HUNTING BIRDS WITH CAMERA}

about three minutes, he tried to rush her. She darted off when he was six feet away and again he struck his pose, proud even in defeat.

Not certain of success, owing to the darkness of the woods, I left the camera set over night, well covered with a rubber cloth. It was well I did so, for the plates were still badly under-exposed. I was back the next morning soon after nine o'clock. The bird was on, and the light much better, shining from in front of the nest. I made the exposure and set the shutter for another trial, this time for prolonged time exposure. It took the bird over three hours to come back, but the weather was warm and the eggs would not suffer, This time the shutter went wrong and stayed open. Again I set it and late in the afternoon obtained another shot. The bird stayed perfectly still when I pulled the string which opened the shutter, so I let it remain open for ten seconds, and this time I had a well-exposed plate. The first one of the morning was also good. So at last I had my reward for three days' labor, walking twenty-four miles and driving sixteen, to complete my series of game bird portraits.

That very day my next door neighbor found another nest, with eight eggs, within ten minutes walk of home. It was in a beautiful grove of white birches under the trunk of a fallen tree, which was prettily overgrown with vines. This bird also was shy and would not let me come within sight of her on the nest without whirring off, not skulking like the other. I had learned now 


\section{HUNTING BIRDS WITH CAMERA}

how to work. In the morning I would hide the camera among the débris of the upturned tree near the nest. I would leave it out and return about noon to pull the thread, allowing ten or fifteen seconds' exposure. In this way I secured the best of all my pictures of the Ruffed Grouse.

In early autumn the young of the year have a curious habit of flying blindly into all sorts of places. The theory has been advanced that these are the profligate young men of the tribe, off on drunken sprees; that they eat too freely of poke-berries, or other fruit, and thereby become intoxicated. Of this there is no certain proof. Perhaps they are trying to escape from hawks, or get bewildered in their wanderings. At any rate they do it and I have observed, or been told of, various instances. Once I found one in my church cellar, and recently one dashed against the window of a neighbor's house and fell dazed to the piazza. It was brought to me and for a month I kept it in a hen-coop to study and photograph. It ate freely of berries and green corn, strutted about, saying "quit, quit," like a turkey, now and then making a purring sound, like a sitting hen, and some whining noises. After a time I sent it to Bronx Park, New York City, where afterward I saw it in one of the pheasant pens.

Ned was not on hand for the grouse shooting just described, but has seen enough to become enthusiastic over this sort of game hunting. As for myself, I have shot the game birds both with gun and camera and, 


\section{HUNTING BIRDS WITH CAMERA}

while I would not despise the former sort of hunting, I like the other much better.

Had this book been written a century or so ago, there would have been several other species to enroll among the upland game-birds of the Eastern and Middle Districts. One of these, the Wild Turkey, has long since disappeared from the region, but is still found in some parts of the South. In a very wild part of central Florida, miles from any dwelling of man, in the year 1902, I happened upon a nest of the Wild Turkey. It was a mere hollow, lined with a few feathers, under a small palmetto, just on the border of the prairie and a great cypress forest. The dozen or so of eggs had recently hatched and the shells, neatly split in halves, lay in the nest. Then there was the Heath Hen, similar to the Pinnated Grouse or Prairie Hen, abundant in those days, but now exterminated, save a small remnant which hide in the tangled scrub-oak tracts on the island of Martha's Vineyard, Mass. The State and other agencies are trying to save them, but the result trembles in the balance. The IVild or Passenger Pigeon which visited the region in countless multitudes has likewise disappeared, with the possible exception of a few stragglers. Various persons report that they have seen them, but, as with supposed ghosts, they never show themselves to a competent witness, and certainly in most cases people have mistaken them for the common Mourning Dove.

This latter bird is still with us in small numbers, 32 


\section{HUN'TING BIRDS WITH CAMERA}

though in the West they are still abundant. One of the most pleasing sounds of spring is the "cooing" of these gentle creatures, "coo, coo, coo-o," it comes, seemingly from afar, it is so soft and ventriloquial. Indeed it sounds to me quite like the distant hooting of the Great Horned Owl. The Mourning Dove used to be considered a game bird, and open seasons were allowed for hunting it. But now, in most States, it is protected like a song-bird, as indeed it should be. It nests in scattered pairs in woods or pastures, building a frail loose nest of twigs, generally in some low crotch of a tree, in a thicket, or even on the ground, where I have now and then seen them. Several times also I have found their two white eggs in old Robins' nests. In late summer and fall they gather into small flocks and resort to grain or stubble fields to feed. They do not hurt the grain, but merely glean the kernels which have fallen. 


\section{CHAPTER III}

THE ROBBERS OF THE FALLS, AND OTHERS

\section{(Hawhis)}

MHIS beautiful May morning, the twelfth, the falls were simply glorious. The recent heavy rain had filled the mountain brook with a rushing torrent which took its fifty-foot leap into the dark rocky gorge with an unusual roar. Thence it thundered down a series of cascades to join the river below, past the dark hemlock forest on both sides which added its dignified whisperings to the tumult of the waters. Here and there among the dark green of the hemlocks showed the pale yellows of the oaks, chestnuts, and birches, which were just beginning to unfold their verdure.

It was warbler-time, and as I scrambled along halfway up the steep declivity, following up the stream on the left bank, I was watching a little company of warblers, among which were several of the beautiful Blackburnians, ceaselessly active in the upper branches of the hemlocks. Just then I caught sight of something which made me lose the warblers. Not far away from me was an oak, in whose second crotch, forty feet up, was a sizable nest of sticks, from which projected, with an upward slant, a stubby thing which looked 


\section{THE ROBBERS OF THE FALLS}

like a hawk's tail. Was it really that? It is easy to see what one wants to see, and sometimes an old stick will prove deceptive. I do not like the feeling of the collapse of one's hopes, but I do enjoy exciting anticipation. My powerful Zeiss glasses showed me that it was surely a liawk and so I stood there awhile enjoying the sight. Now I cautiously advanced and came nearly to the tree before the hawk heard my steps above the din of the waters. She stood up in the nest, and away she went, with a shrill, high-pitched scream- "whe-e-e," and alighted upon a tall tree a hundred feet away, where she continued to squeal her displeasure.

“Broad-wing! Fine!" I ejaculated. Not our commonest hawk by any means! And an obliging Broadwing! I had no climbing irons with me, but as I examined the situation, it seemed as though the bird had had my convenience in mind in selecting the site for her nest. About fifteen feet away was a rather large hemlock, with step-ladder branches beginning about fifteen feet up, and close beside it a young hemlock, making another step-ladder up to the first branch of the big tree. To run upstairs was the simplest thing in the world, if one did not mind elevation, and very soon I was overlooking the nest with its two sizable dirty white eggs blotched with brown, lying on a bed of bark, dry leaves and twigs, with a few green hemlock sprays on the side for ornament. It was too nice up there to hurry down. The tree was on the edge of quite a steep declivity, and far below I could see the 


\section{THE ROBBEKS OF THE FALLS}

swirling water, which roared away unceasingly, almost loud enough to drown the angry screams of the hawk, which was now making dashes at my head, sheering off just out of reach.

But it would not do to stay there longer and lose the golden moments, so I descended, crossed the brook on some projecting rocks, and entered an extensive and beautiful hemlock grove. Within a few rods of the great fall I recalled that there was an old hawk's nest high in a hemlock, which I had examined year by year, hoping to find it again occupied, as hawks often return to their old nest, or else it is taken by other hawks even after the tenement has had years of disuse. Seven springs successively $I$ had looked at it, but I was not hopeless, so long as it held together. This time it certainly looked large and fresh, as though it had been added to. Under it were freshly-broken sticks and one hawk's feather. Though no one answered to my stormy knocks at the door, I went upstairs without invitation, and looking into the airy bedroom I found three plain bluish-white eggs characteristic of the Cooper's Hawk, laid, as is usual with this species, on scales or chunks of hard, rough bark without any other lining to the big stick nest. And now, seeing that the game was up, Mrs. Cooper announced her displeasure by an angry demand as to what business I had up there without her permission-“"cack-cack-cack-cack-cackcack!" “Oh, none at all; your humble servant," I said, meekly descending, when I had looked her home 


\section{THE ROBBERS OF THE FALLS}

over to my satisfaction. "But what made you desert me in all these eight years?"

Wasn't this great to find two hawks' nests in the same woods not a quarter of a mile apart! Here was fun enough laid out for Ned and me. But it will be dangerous for other birds and squirrels and rabbits which live here. These falls will witness many a tragedy. Little do the picnic parties which come here almost daily realize that four savage robbers are watching them from the tree tops. How blind the average people seem, for I can hardly imagine myself not discovering at least this nest right in the pienic grove before I had been there an hour.

It will seem strange if these robber families which make their living by killing every smaller creature that comes in their way manage not to disagree among themselves and have some terrible fights. But the probability is that each pair will stay on its own side of the brook and attend strictly to its own business. If either is the aggressor, I think it will be the Cooper's Hawks, for they are bold, pestilent fellows, the worst nuisance of the whole tribe to the farmers, like their smaller relative the Sharp-shinned Hawk, while the Broad-wing is a slow-moving, sedate sort of bird, contenting itself mostly with the humbler sorts of prey and seldom troubling poultry.

I am wondering another thing, too, whether these numerous mountain brooks of this hilly country, with their falls and deep rocky gorges, do not all have their 


\section{THE ROBBERS OF THE FALLS}

robbers. Only two days before this I was descending the gorge of another similar mountain stream hardly two miles from here, when I noticed a hawk's nest in an oak tree over the water. It was an old one, not occupied, and presently, as I went on, I came to another in the top of a tall dead birch tree, also right over the stream. It was evidently not occupied, but I clapped my hands loudly to inquire, and was surprised to see a Broad-wing fly away from somewhere lower down, though not from the nest. Innocently assuming that she was preparing to use this nest and had been perching silently near it, I was about to go on without climbing, as I had no irons with me, and to return later, when I happened to espy a neat new nest in a low hemlock, not half as ligh as the nest in the birch, well concealed in the branches. White down clung to the twigs all about it and there was now no question as to where the hawk had flown from. It was only thirty feet up, with branches all the way, and I was quickly examining the two eggs, similar to those of the broad-winged robber of the other falls. Growing beside this tree, at just the right distance to set a camera, was a slender but strong young oak. I had never photographed the Broad-wing Hawk from life, and now, with these two nicely situated nests, certainly there was a fine chance.

My friend Ned was as yet inexperienced in the joys and triumphs of hawking and I had him with me a few days later when I made the first try at snapping the Broad-wings, selecting the nest at the big falls. 


\section{THE ROBBERS OF THE FALLS}

Meanwhile, one afternoon, I had gone the rounds again, and by each of the three raptores' nests- "raptores," meaning robbers, is the Latin scientific name of the order of hawks, owls, and the like-I had tied up a small cereal box with a round hole in one end, to represent a camera and lens, with a piece of burlap or sacking pinned over it, like a focusing cloth, placing this in the hemlock tree just where I planned to set the camera. The hawks generally get used to the novelty after awhile, and, when the real camera is set there, they do not mind it at all. The main trouble is to make them believe you have left the woods, for they will not go to the nest as long as they think anyone is near.

The hawk was at home, having become used to my dummy camera. With my own $4 \times 5$ camera slung over my shoulder in its case and other necessary instruments in my pocket, I began to climb and told Ned to come up after me. By the time he was half way up the tree he hesitated, for it seemed a long way down to that roaring brook. I told him to keep his eyes on a level and not mind the rocks below, because there were plenty of strong branches and he could not fall. So he got up where he could look into the nest and watched me fix the camera.

It took me quite a while to rig it up, screwing it with a bolt and ball-and-socket clamp to the right hand side of the trunk, so it could point toward the nest and nothing be in the way of the plate-holder. I took off 


\section{THE ROBBERS OF THE FALLS}

the back lens of the doublet and used the single front member, of eighteen inches focus, which gave a good large image of the nest even from that distance. When it was focused and everything ready I tied the end of the spool of strong black linen thread to the shutter, dropped the spool to the ground, set the shutter, and then we climbed carefully down, so as not to pull the thread and spoil the plate.

The next thing was to find a good hiding place from which to watch for the return of the hawk. About a gunshot away, up the hill, a large chestnut tree had fallen, and under it seemed a good chance to hide. Ned held the thread so the shutter would not be released, while I further unwound it and laid it out carefully, to avoid tangling, to the old trunk. Crawling in under, I called Ned, and he hurried up and came in too. From a peek hole I could just see the nest through the leaves and branches. The only thing to do now was to watch when the hawk came back to the nest, and then pull the thread carefully so as not to jar the camera while the shutter opened for the required half second. The bellows were so long that in the woods this was none too much, even with the lens at full opening.

We lay perfectly still and listened to the hawk music. Both of the pair were flying around and screaming away like good ones. It seemed as though they surely would stop in a few minutes and get to work at housekeeping again, but they kept right at it. In 


\section{THE ROBBERS OF THE FALLS}

half an hour we felt pretty well cramped. Ned com. plained that his neck ached like fury, and mine was in the same condition. The hawks were still alarmed and something was evidently wrong.

"I don't believe it's the camera that disturbs them," I said to Ned. "I think they know we have not gone. What do you say to going off out of sight, making plenty of racket as you go, and sce if the birds can count and remember there was another fellow?"

"All right," he replied, and he left me, secretly glad, I am sure, to straighten out the kinks in his persecuted neck.

He had not been gone two minutes before the yelling ceased. There was dead silence awhile, and then I saw a hawk alight in a tree near the nest. Next she flew to another branch, and then glided right on to the nest and stood erect, looking and listening. This was my chance, and steadily and slowly I pulled the thread taut. The hawk gave no sign of having heard the shutter and settled down to brood. I gave her ten minutes to get over her alarm and watched her through my field glass. Now and then she would turn her head and then would settle back with a sleepy air, just like an old sitting hen.

The exciting question now was whether or not the shutter had sprung, or had the thread got tangled. Quietly I crawled out from my retreat and away from it, so as not to show the hawk where I had hidden. As soon as I walked boldly, she flew, and I hurried to $4:$ 


\section{THE ROBBERS OF THE FALLS}

climb the tree and was overjoyed to find the shutter closed.

"Good work!" I shouted to Ned. "I've got a picture, and we'll try for another." So I changed the plate, set the shutter again, and this time walked off noisily beyond the $\log$ and to one side of it. Then I dropped to the ground and erept silently to it on my hands and knees. The hawk did not see or hear me. She was silent, after a few moments, and seemed to go off somewhere. But in a quarter of an hour I suddenly saw a shadow and something glided swiftly through the woods, and almost immediately she was on the nest. This time I let her settle down to incubate before I pulled, and I "got" her sidewise, a fine clear picture. The hawk was becoming accustomed to my approaches, and, anyhow, Broad-wings are the tamest of the hawks. As I changed the plate I called to Ned, for he was anxious to be in the game, and I thought that our robber friend would now give us permission. We both hid, and this time she thought the coast was clear and soon came back. She flew straight toward the nest and seemed to go to it, yet absolutely disappeared.

"Where is she?" whispered Ned excitedly. "I can't see her at all." "I think," I hurriedly answered, "that she is close to the nest behind that big branch. Anyhow I'm going to try it." So I pulled the thread and the hawk flew from just where I thought. What luck that I pulled then! This picture was a wonder. The 42 


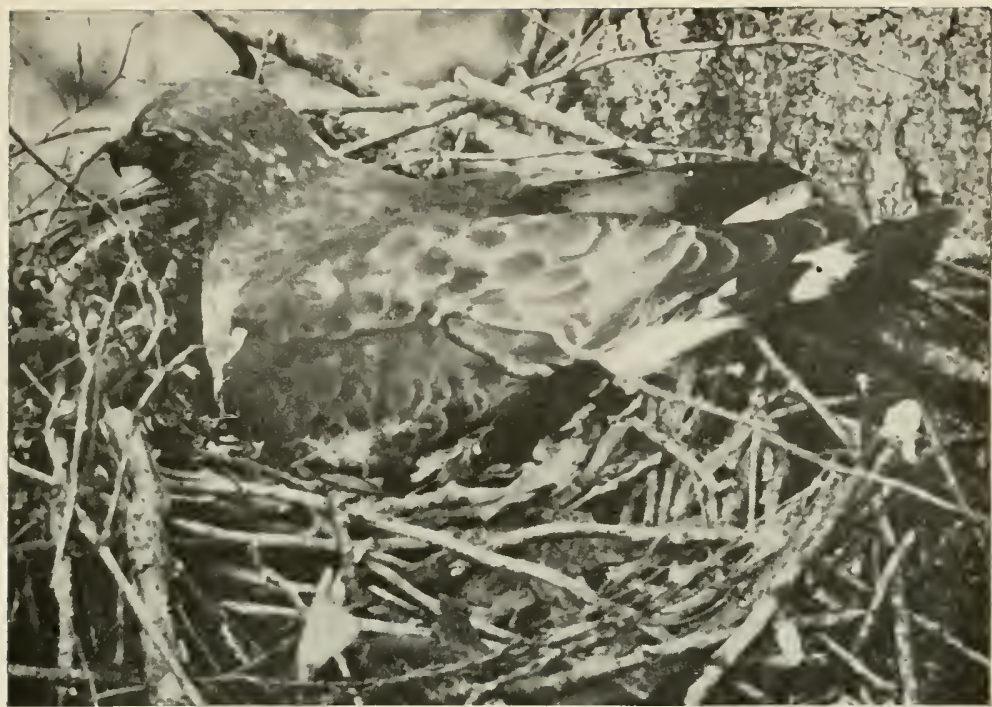

Broad-winged Hawk on nest. "Let her settle down to incubate" (p. 4z).

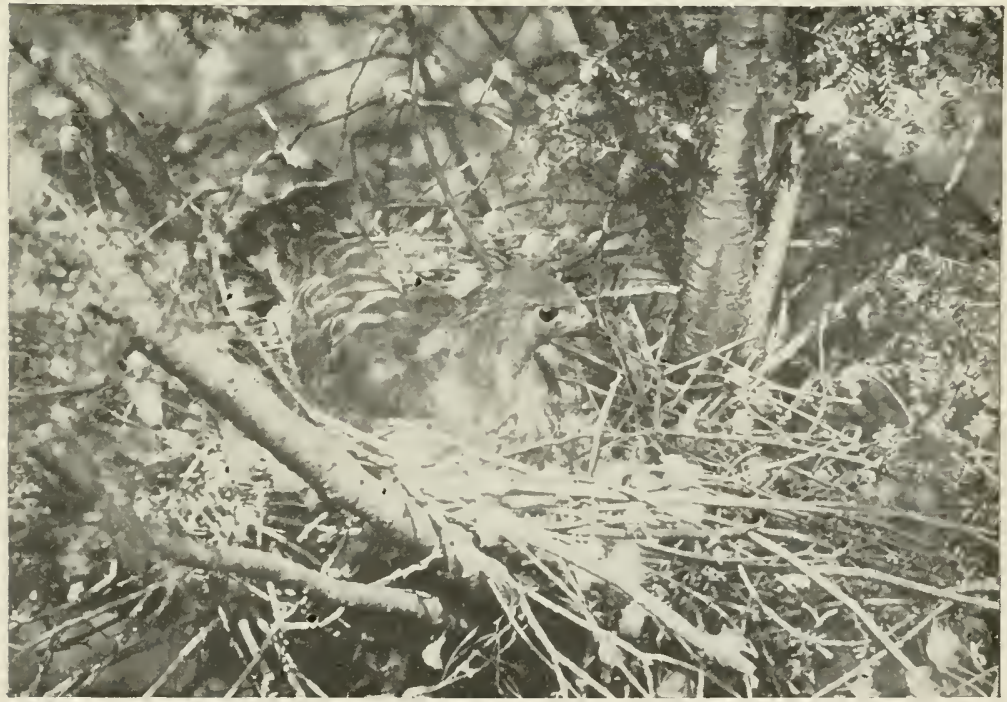

Broad-winged Hawk on nest. The better of the pietures saved from the aceident (p). 44-6). 


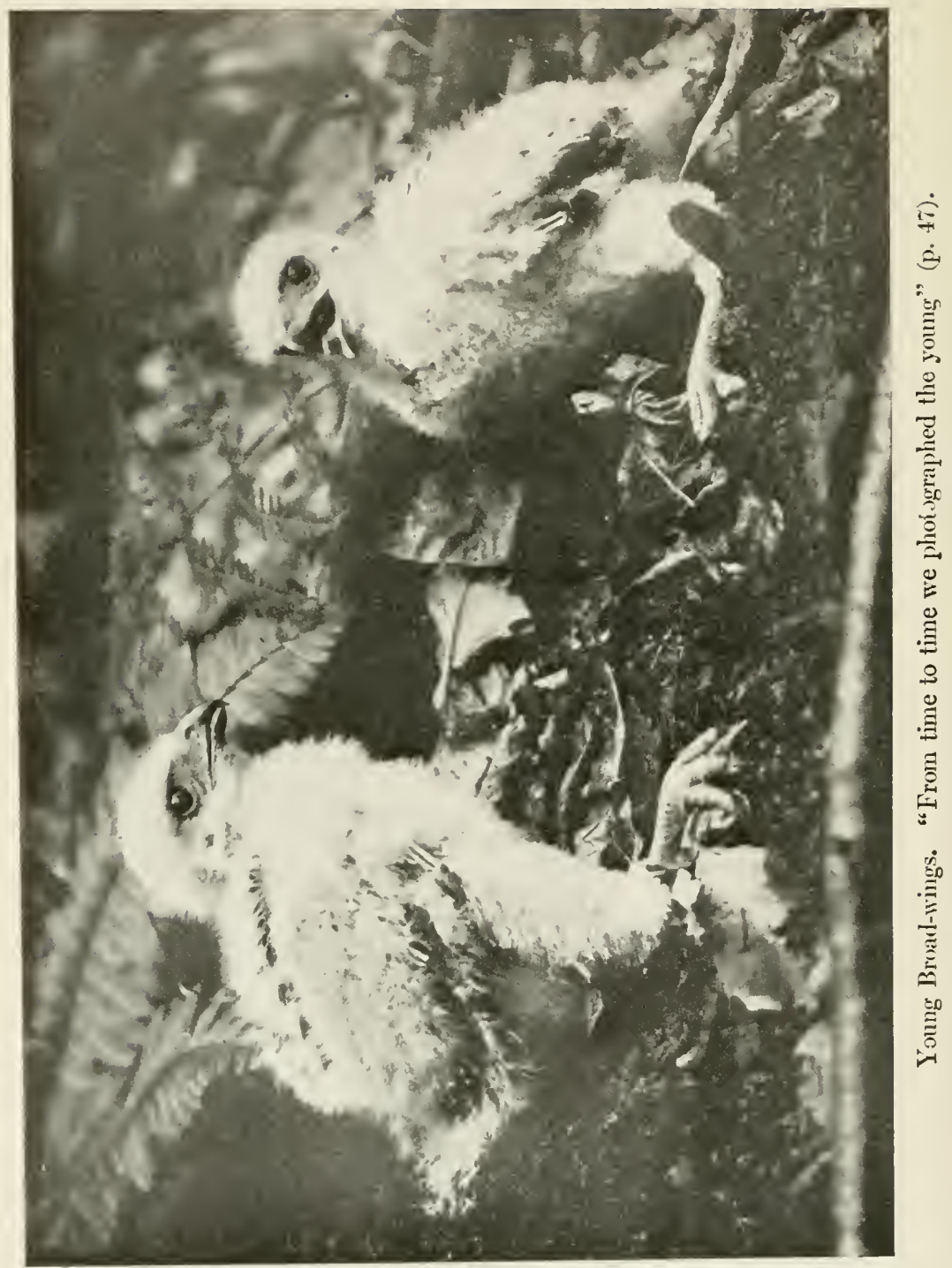




\section{THE ROBBERS OF THE FALLS}

hawk stands on the stub, in the act of entering the nest with a chunk of bark. Why did she bring it? Others can answer as well as I. I have seen other hawks bring things, too. They carry in fresh green sprays or leaves each day, apparently for ornament, just as we have our house plants, but it is not so clear why they bring lining when the nest has long been built. Possibly it is because the nest keeps breaking down, or the rotten sticks crumble, so they have to keep adding to it, and get in the habit of bringing something each time they return not otherwise laden, so as to save steps, just as the farmer's boys are told to bring in an armful of wood every time they come to the kitchen.

We got three more good shots that day, six in all, the best day's hawking I ever had, for every one of them was good. I let Ned pull the thread once, so that he could say that he had taken a picture of a wild hawk from life.

I was alone when I photographed the other Broadwing and Ned missed one of the times of his life! The hawk would not go near the nest while I was in the woods and I had no one with me to go away, so next time I brought my little brown umbrella tent and pitched it down the stream, where I could just see if the hawk went to the nest, though I could not see her upon it. It was no fun rigging the camera in that slender oak, with nothing but the trunk to hold on to, one foot in a small crotch, the other supported by the 


\section{THE ROBBERS OF THE FALLS}

iron spur. There were sharp rocks beneath and I had to be exceedingly careful. Indeed one could not be enough so, having to use both hands at times to adjust the camera. It was awkward, nerve-trying work, and took a long time, but it was finally done, the thread cable laid, and I crawled into the tent. The hawk was suspicious, and it was only after hours of waiting with eyes at the peek hole and neck almost paralyzed, that I secured two shots at her on the nest, and then, with the precious plates, I followed the path back to the "rig."

I had driven the horse up a rocky wood road until the ascent became too steep and rough for further progress, and hitched to a tree in a little opening. It was two o'clock when I drove down, and, as I had not brought much lunch, I was hungry. Just then I remembered an apple in my pocket which a boy whom I met had given me. It proved quite hard, so I opened my knife to cut ic and let the horse climb unguided down the declivity. I only looked off for a moment, but it was a moment too long. The horse swerved slightly and made the wheel on the right strike a steep rock projecting close to the trail. As quick as a flash the buggy was overturned and I was pitched out into the bushes, knife in hand. Fortunately I was not cut, but I lost the reins and the frightened horse ran away, galloping down the rocky trail, the buggy bottom-sideup, camera, plates, tripod, everything, being scattered to the winds. Then with a flying leap down a steep 


\section{THE ROBBERS OF THE FALLS}

pitch, where there was a sharp turn in the road, the horse and buggy disappeared and all was still.

My state of mind may be imagined as I hurried after the flying apparition. Rather singularly, the first thought that came to me was that after working nearly all day for those hawk pictures, they were all smashed to pieces. But I passed the plates and camera where they had fallen and rushed on to see what had become of the horse. When I came to the pitch and bend in the road I saw the sight of a lifetime. There was the overturned buggy and a capsized horse entangled in the harness, helpless from lying with her legs uphill. These members were feebly waving in the air, as though set on a derelict for signals of distress.

A man in the field below had seen the final catastrophe and hurried to the rescue. Together we managed to unhitch the "fool" animal and drag away the buggy with its two dished wheels. But the horse could not get up, though I could see no injury save a slight cut on one leg. I suggested that it only needed to turn turtle and roll down hill, but, as it would not do this, we must do the little trick for it ourselves. It seemed rather ungracious to ask the farmer to take the business end of the animal, so I had him grasp the front legs, while I gingerly laid hold of the "kickers," and we bent our backs. Presto! The horse rolled over and then struggled to its feet, where it stood taking in the situation. Then its head drooped. Was it going to die? It was a young and valuable horse which I had recently 


\section{THE ROBBERS OF THE FALLS}

bought, and I felt anxious. What do you think it did? The strongest instinct asserted itself, even in the hour of trial. The horse was even hungrier than I. Grazing, as I live! We men looked at one another and laughed.

Then I hurried to take further account of stock. The camera was unbroken; the precious plates were sound, and produced two good pictures after all. IVe pushed the spokes back into the hub and in a quarter of an hour I was driving home as though nothing had happened, slowly though, for the wheels might break down again, and actually, the horse for the next week seemed afraid to "step lively," evidently fearing lest it should again fall down!

When I met Ned and told him the story, the first question he asked was-"Did you photograph the wreck?" Well, I never! What a brilliant idea and what a stupid omission to be so concerned about a horse as to overlook this wonderful opportunity. I almost wanted to go back and try it over again. But it was not to be. "Next time, Ned," I replied regretfully, "such a bright boy as you must surely be along when anything interesting happens." "You can count on me, if I know it," he said.

The young hawks hatched in due time, one only in the great falls nest, but both in the other. The evening: before Ned's birthday, the second of June, as we climbed to the latter, we could hear a "cheep, cheep," as from under a mother hen. What was our surprise 


\section{THE ROBBERS OF THE FALLS}

to find eggs still in the nest. But each one had a hole in it and a yellow hooked bill sticking through. "Your birthday will be the Broadwings' birthday," I said to Ned.

From time to time we came and photographed the young in both nests until they were ready to leave, in early July, and also the young Cooper's Hawks, only two of which hatched. I had placed a dummy camera six feet away in the next hemlock, after the young hatched, but I did not get time to experiment on the mother. She was a shy rascal and one could hardly get a glimpse at her, even by stealing toward the nest on tiptoe. One day I went to the nest, leaving Ned at the foot of the great fall sailing chip boats. This time Mrs. Cooper came to meet me and, perched on a low branch quite near, gave me a terrible scolding. Ned could not hear my yells above the roar of the cataract, so I went to summon him for the fine sight, but when I returned with him the hawk had gotten over her sudden streak of boldness and taken herself off.

By far the best way to get familiar with hawks is to find their nests and then from time to time visit them at home and study their habits. At other times one can get only occasional glimpses at them, as they soar overhead, or dive into the poultry yard, or dash upon one in the woods, or perch upon some tree by the roadside. But one can learn more of hawks in a season by finding a few of their nests than would be possible 


\section{THE ROBBERS OF THE FALLS}

otherwise in years. They are such fine, large, spirited birds, their nests big, in big trees, in big woods, and there is a peculiar fascination in hunting for them. The boy who catches the hawk fever will find it almost impossible to cure. I had a severe attack of this fever when about fifteen years old, and there is no sign yet of my getting over it. I fear that Ned has caught it from me and will be in for it for life.

During the late fall and winter I usually have some fine tramps exploring the groves or woodland tracts where there is the tallest timber, looking up likely nesting places and old nests which may be occupied another year. Hawk's nests are built entirely of sticks; those built wholly or in part of leaves belong to squirrels. Then there are crow's nests, which cannot always be distinguished from those of hawks.

In the nesting season the signs of a new, occupied nest are these: the ends of the stieks in the nest appearing a lighter color, freshly broken; similar sticks on the ground beneath the nest; bits of white down clinging to the nest or to twigs near it. The question is often settled by seeing the hawk fly off as we approach.

It is great fun to hunt up the nests of the big "Hen Hawks"-Red-tails and Red-shoulders-in the first of the season, during April. The temperature is fine for vigorous tramping and climbing, and it is splendid, exhilarating sport. Each pair of these birds stay in the same woods year after year, and cither use the same 


\section{THE ROBBERS OF THE FALLS}

nest, or another not far from it. Sometimes they alternate between two or three nests, which remain as landmarks for years.

This was the case with a pair of Red-tails about four miles from my home. About every other year they would go off to some nest which I did not succeed in locating, but the next year they would be in either of two nests about two hundred yards apart. One was a big affair, sixty feet up a giant oak which grew from the foot of quite a precipice. From the top of this ledge, by climbing a sapling, one could see into the nest. It was a hard matter, though, to climb the old oak to the nest, the trunk was so thick and the bark so loose. But Ned did it with the help of a rope, and photographed the nest and eggs very successfully.

The other nest was in a chestnut stub, forty feet up. Back from it the hill sloped up quite abruptly. There was a thick hemlock tree with branches down to the ground on this slope near the nest. One day I pitched my umbrella tent under the hemlock, and the next afternoon when she had become accustomed to it, I had Ned leave me hidden in it and took three pictures with my high-powered telephoto lens of the mother hawk as she returned to the nest.

This last season the pair occupied a new nest in the same woods, in a chestnut tree which grew near a hemlock. There was one young hawk in the nest, hatched about the twenty-seventh of April. Up in the hemlock I rigged a dummy camera which was so well 


\section{THE ROBBERS OF THE FALLS}

concealed by the evergreen foliage that the wary hawis paid no attention to it. Down the side hill, as far off as I could see the nest through the woods, I pitched my brown tent and left it there indefinitely. By rigging my camera in place of the dummy, connecting it with the tent by a thread and hiding there, I secured some interesting pictures, after a number of attempts, and long vigils. The mother hawk would perch on a distant hemlock on the ridge of the mountain and silently watch for over an hour. Then she would fly off and be gone a couple of hours longer before returning to the nest. One afternoon after watching steadily for four hours from the peek hole in the tent, I fell asleep -the only time I ever did such a thing afield. I only dozed for a few minutes, but it was just at the critical time, for the old hawk came and fed her young one and flew off just as I had awakened and was in the act of pulling the thread. The day was wasted, and I felt unutterable things. However I tried again and again. Another time the shutter stuck and made useless a long vigil. But finally, after some rather poor exposures, I snapped the keen and wary creature standing quietly by her chick, enjoying its society-a beautiful picture. Another day, as I watched, the old bird came with a snake dangling from her claws. She circled around three times, then hastily deposited the snake and was off before I dared to pull, as I had set the shutter for half a second. I watched for her return for several hours, and then she came and proceeded to 


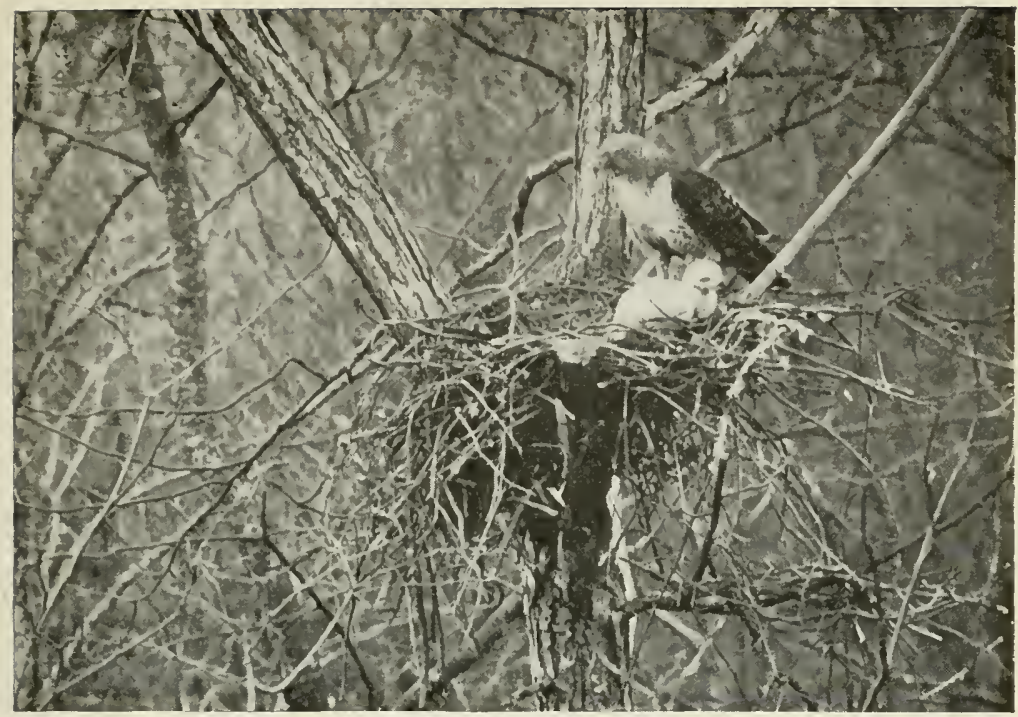

Home life of the Red-tailed Hawk. "The wary creature standing quietly by her chick" (p. 50).

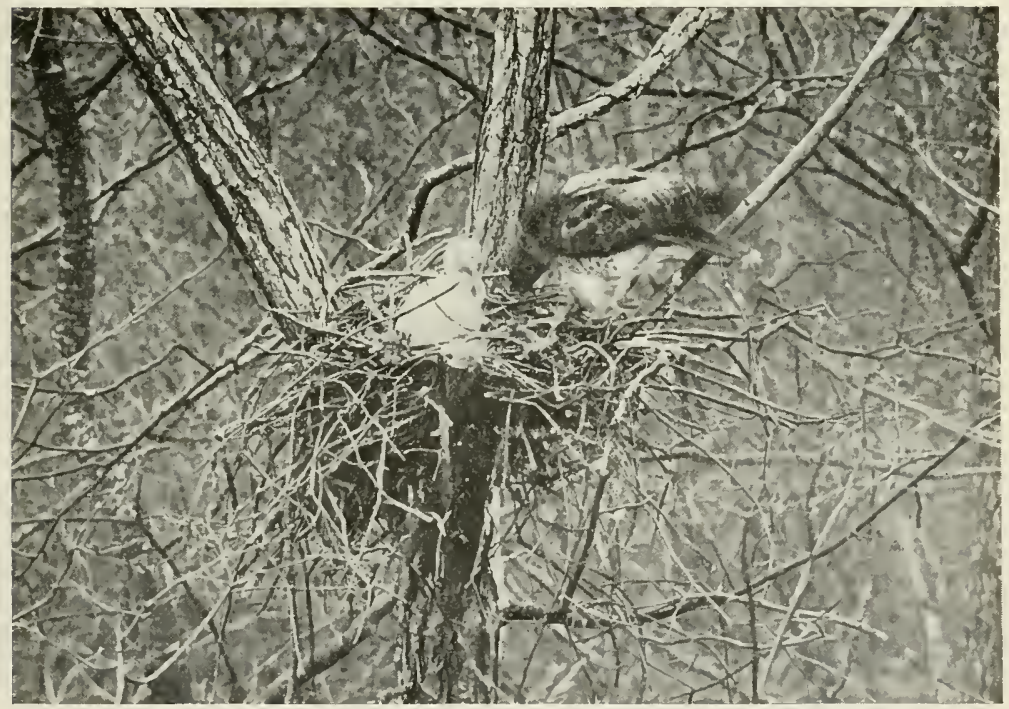

Red-tailed IIawk. "Proceeded to tear up the snake for her young one" (pp. 50-1). 


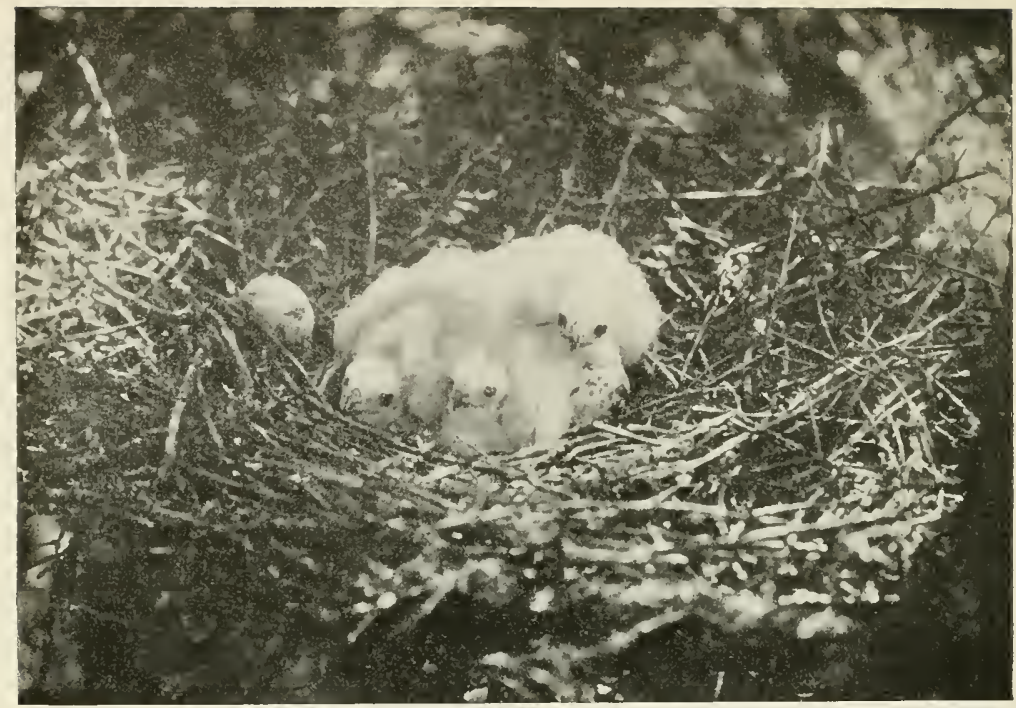

"Three little Sharp-shinned Hawks ... . and two mhatched eggs were our prize $^{*}($ p. $5 \stackrel{2}{2})$.

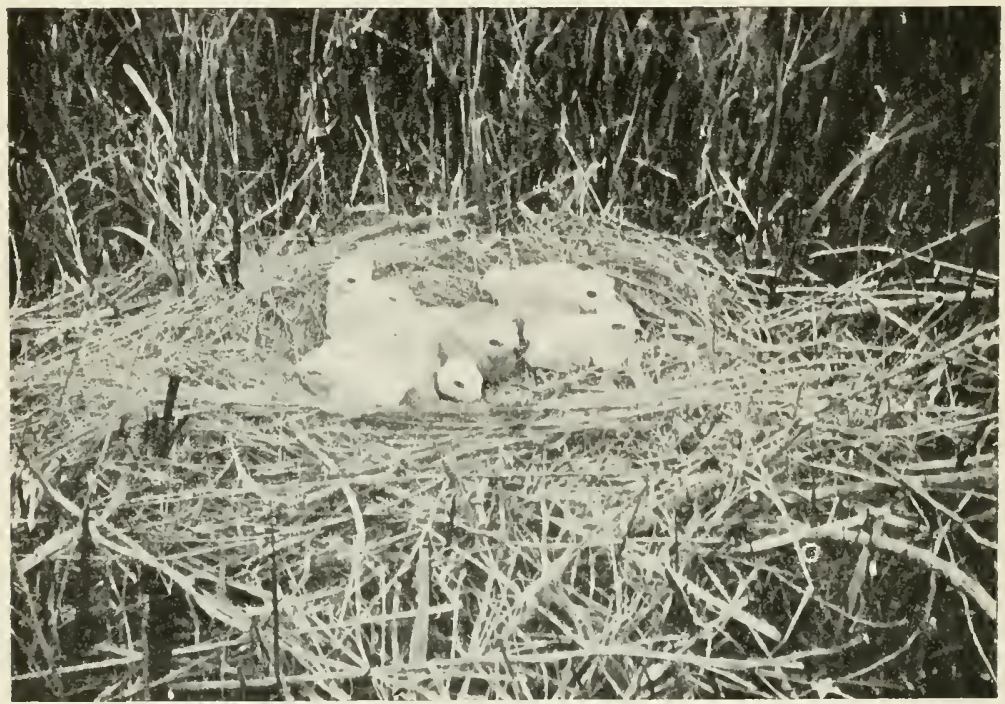

Nest of Marsh Hawk. "They build on the ground" (p. 53). 


\section{THE ROBBERS OF THE FALLS}

tear up the snake for her young one, and the camera this time canght her in the act. On the sixth of June I photographed the youngster, fully fledged, about to leave the nest, at the ripe age of forty days.

Sometimes hawks betray the locations of their own nests. Usually they are pretty careful about approaching them, but the Red-tails and Red-shoulders are often noisy in the woods near the nest, and can be seen circling over it. Noticing this, people living or working near the woods can often put one on the track of a nest. The Cooper's and Sharp-shinned Hawks often cackle angrily when one comes near the treasure, and thus betray their secret. Whenever a small hawk sets up a "cack-cack-cack" in the woods in nesting time, one may be confident that a nest is close by.

A Cooper's Hawk which I once photographed on the nest used to build every year in the same tract of woods. A friend of mine was unfortunate enough to live near these woods and was trying to raise chickens. Though he had ropes stretched all about hung with bottles and rags, and every corner had its scarecrow-or "scarehawk!"-neighbor Cooper was accustomed to visit him on friendly errands several times a day and each time had to have a chicken. So I told him I would break up the nest for him, and went in there one afternoon. After exploring nearly the whole woods in vain, I came back and entered a grove of tall trees so near his house that I had no idea that a hawk would build there. Immediately the hawks set up a prodigious 


\section{THE ROBBERS OF THE FALLS}

cackling. It took but a little time to find the nest in the tip-top crotch of a chestnut, forty feet from the ground, the twigs all around fairly bristling with down. This was the twenty-first of May, and the amount of down indicated that incubation was well under way. Strapping on my climbing irons, I went up, and brought down the four eggs to give to an egg collector. This stopped the raids on the chickens, for the hawks forthwith disappeared.

Later that same season Ned and I found a nice nest of the closely related Sharp-shinned IHawk, the second one of this bird I have found on the fourth of July. We were exploring a very wild mountainous region, in a swampy tract of black spruce woods. We entered it after skirting a typical wet sphagnum swamp, and about the first thing I saw was a nest of sticks in a small spruce, fifteen feet up. Ned and I climbed the tree, and we stayed up there some time, enjoying the interesting sight. Three little Sharp-shinned Hawks in white down, and two unhatched eggs were our prize in the neatly built nest of small sticks. As we studied them, the old hawk came dashing up, and from trees near by made a great ado. The wind up there on the mountains was blowing almost a gale, and the trees were swaying like so many reeds. By waiting patiently for momentary lulls in the wind, I finally accomplished it.

These five species of hawks are the only ones that we are liable to find in our woods in the nesting time. The Bald Eagle is only a big hawk, but it is scarce 


\section{THE ROBBERS OF THE FALLS}

and seldom nests in this region. I have seen many nests in the South, and it is probable that most of those we see have wandered up thence after the nesting season. The small Pigeon Hawk is a common migrant.

The Osprey breeds iñ colonies in a few places along the seacoast. They are beloved and protected, and build on isolated trees on farms, often right in the dooryard of a house. I only wish they would build in a tree on my front lawn! Any person who tried to molest them would find me looking for trouble. The nests are as big as haycocks and look out of place up in the trees. They are made of large sticks and all sorts of rubbish. One that I examined had an old umbrella woven into it, another an old dried dead hen! I sat in the nest myself, though, and found it very comfortable. But it is hard getting there. You come up underneath, and the thing bulges out beyond you like a balloon, and there seems no easy way to get up on top.

Hunting Marsh Hawks' nests is very different from this other "hawking." They build on the ground in a bushy swamp or wet pasture, and one has to tramp around at random until he comes within a few steps of the sitting bird. She will fly up and go through an astonishing performance of diving at one's head and screaming, but I never knew one to actually strike.

Then there is the little Sparrow Hawk which stays with us only in small numbers, nesting in hollow trees or in Flickers' holes along the borders of farms, or in 


\section{THE ROBBERS OF THE FALLS}

pastures. He is a harmless and useful little fellow, feeding on mice, moles, and insects.

Most of the hawks appear only infrequently in winter, but I have seen about all of them, at rare iniervals, even the little Sparrow Hawk. On a bitter cold clay, the tenth of February, a neighbor caught one in his barn, where the poor little thing hoped to catch a mouse to keep itself from starving. Red-tails are the commonest, and frequently I meet them perched on a large tree by the edge of the woods or by the roadside. One had better look sharply at the supposed Red-tail, for it might prove to be the rarer American Roughlegged Hawk from the North, a large bird of the same size, but with feathered legs like the Golden Eagle.

At long intervals there is a winter when the fierce Goshawk is common, following unusual migrations of northern birds. The winter of 1906-7 was such a one, and these hawks were frequently seen well down into the Middle States, or further. Sometimes they came almost in flocks-loose, straggling, companies. I saw one Goshawk from the window of a train as it hovered over a river. In the town where I live a boy shot one sitting on his henyard fence. Its crop was stuffed full of the flesh of a fowl which it had just killed and was in the act of eating. In the next town a friend of mine shot one of these hawks as it perched on a fence at the edge of some woods. The snow was deep, and, as he picked up the dead hawk, a Ruffed Grouse darted from the snow close at his feet. Evidently the hawk 


\section{THE ROBBERS OF THE FALLS}

had been in pursuit of it and the poor bird had dived headlong into the snow to escape its fury. The hawk had then alighted on the fence and waited for it to come out. As I write this, he looks down on me reproachfully with glass eyes from the top of my case. Ah, you rascal, you will kill no more grouse! Yet, after all, who has a better right? I am not so sure that we, out of our luxurious abundance, had better make the claim.

Ned and I are so fond of hunting hawks with the camera and studying these bold, breezy people of the forest, that we fairly mourn to see them exterminated. Of course we do not blame those for killing them whose property they devastate, yet we wish that people would in justice discriminate between the pestiferous and the harmless or useful kinds, and cultivate enough of the modern "outdoor" spirit to make them enjoy seeing wild life in nature and get away from the ignorant, worn-out notion that the only good hawk is a dead one.

The Biological Survey, of the U. S. Department of Agriculture has shown that only the Accipitrine hawks -Cooper's, Sharp-shin, and Goshawk-are injurious. The so-called "Hen Hawks" only occasionally attack poultry, especially in the winter, when driven to it by starvation, but by killing the smaller varmints and insects do more good than harm. Now and then an individual, like the tiger, acquires a taste for the wrong sort of meat, and may properly be suppressed. So, 


\section{THE ROBBERS OF THE FALLS}

kind reader, I beg of you, do, please, not shoot a hawk because he is a hawk, but only if you are sure he is the culprit. Learn from a handbook of birds to distinguish the different kinds. You will enjoy their acquaintance and then will not be in danger of mistaking your friend and helper for a murderer.

Now and then we shall probably see a large black bird with enormous spread of wing soaring on almost motionless pinions, drifting easily along with the breeze, It is the Turkey Vulture, or Turkey Buzzard, which is classed in this group of raptorial birds. Though from afar it would seem a beautiful creature, so graceful in flight, it is distance which lends the enchantment, for at close quarters it is a foul-smelling carrion-monger, with an ugly, featherless red head and neck. Yet for all that it is a useful scavenger and an interesting bird, and I wish we had more of them in the northern districts to give us exhibitions of graceful, easy flight. They are accidental in New England, where I have seen only tro, but are more frequent in the Middle States, and, of course, abundant in the South. They build no nest, but lay their two large handsomelymarked eggs on the ground under a bush, or in a hollow log or stump. 


\section{CHAPTER IV}

\section{THE BIRD OF NIGHT}

\section{(Owls)}

F all classes of birds were as hard to become acquainted with as the owls, the increasing thousands of boys and girls, men and women, who discover for themselves the fascination of the sport of bird study would mostly get discouraged and try other things. Even I must confess that I should need to see a bird now and then to keep up my enthusiasm. But, as far as the bird of night is concerned, sometimes, in spite of all my efforts, whole seasons slip by without my meeting with a single owl. Even Ned, with all his activity, has but very few times in his life discovered an owl in the wilds, other than what I had first located. The owls are both scarce and secretive, usually remaining in hiding during the daytime, and the student need not be too much chagrined at being unable to find them. Fortunately there are plenty of other birds to interest and occupy one afield. So hunt away, keeping the eyes peeled for the hid treasure, and some time, surely, you will find the bird with the big eyes, and get such a thrill of delicious excitement in your success that you will not begrudge the waiting which made the joy of attainment so keen. 


\section{THE BIRD OF NIGHT}

Fortunately, though, the owls have voices, and most of them are inclined, at times, to lift them up in singing -if one may so call it. This makes an intelligent and persistent hunt for them quite likely to succeed, provided, of course, that there are any owls there to find. And owls there almost certainly are within the limits of any country town which is reasonably well wooded with fairly large timber and is not too suburban.

Our two principal "hooters" are the Great Horned Owl and the Barred Owl, both of which are confused under the popular name of "Hoot Owl." They are both big birds, especially the former, which is also distinguished from the other by having large ear tufts, which look like horns. They do not migrate to any great extent, though they wander more or less in winter when food is scarce, but stay, for the most part, in the same general region or tract of woodland in which they nest. In the autumn they begin their loud hootings. One can easily distinguish the two by these sounds, for the Great Horned Owl has but three hoots to his song, while the Barred fellow's vocal effort is much longer and more elaborate. They are most apt to hoot about sundown on mild or moist days when it threatens to rain or snow, and, indeed, they are pretty good weather prophets. Probably they "feel it in their bones" when a storm is brewing, though there is no likelihood that these hardy creatures are rheumatic. These hootings are their love notes, their mating cries, and I just wish I could find out from them why their fondness deepens 


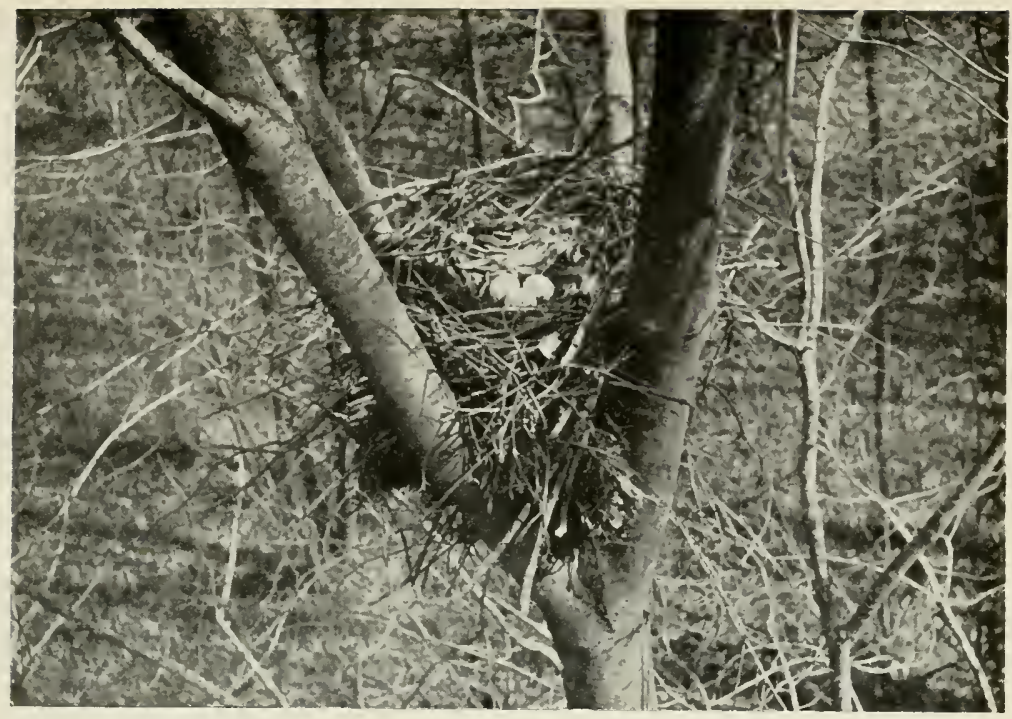

Nest of Red-shouldered Hawk. The nest in which the Hawk and Owl both laid egrs together (pp. 6:-3).

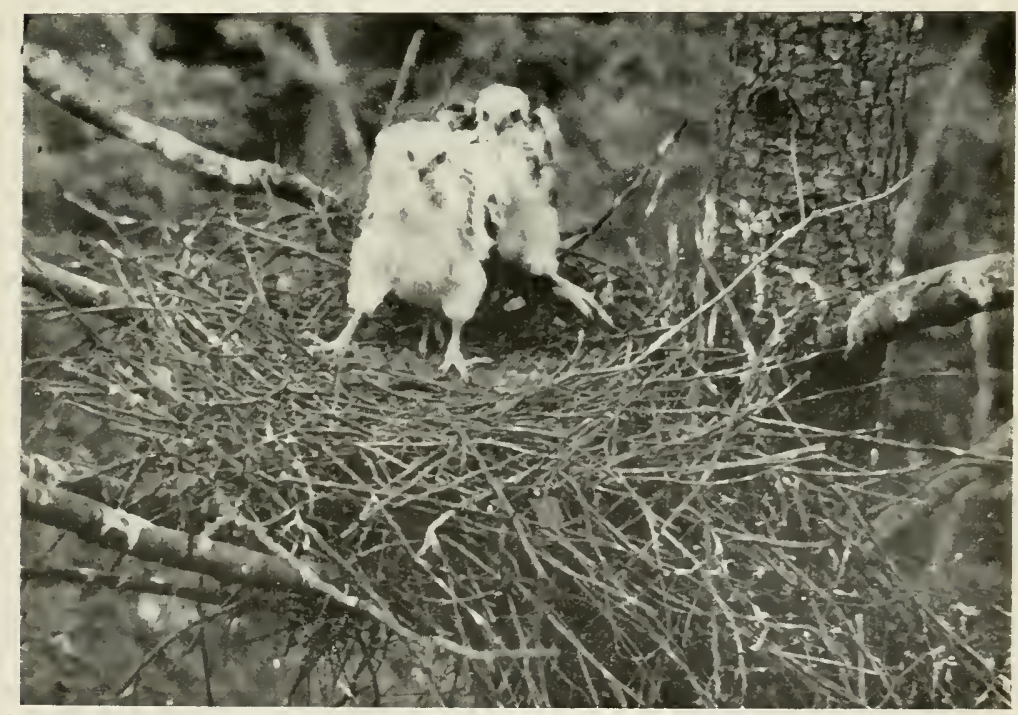

'The Cooper's Hawks' nest by the falls. "Only two of which hatched" (p. 47). 

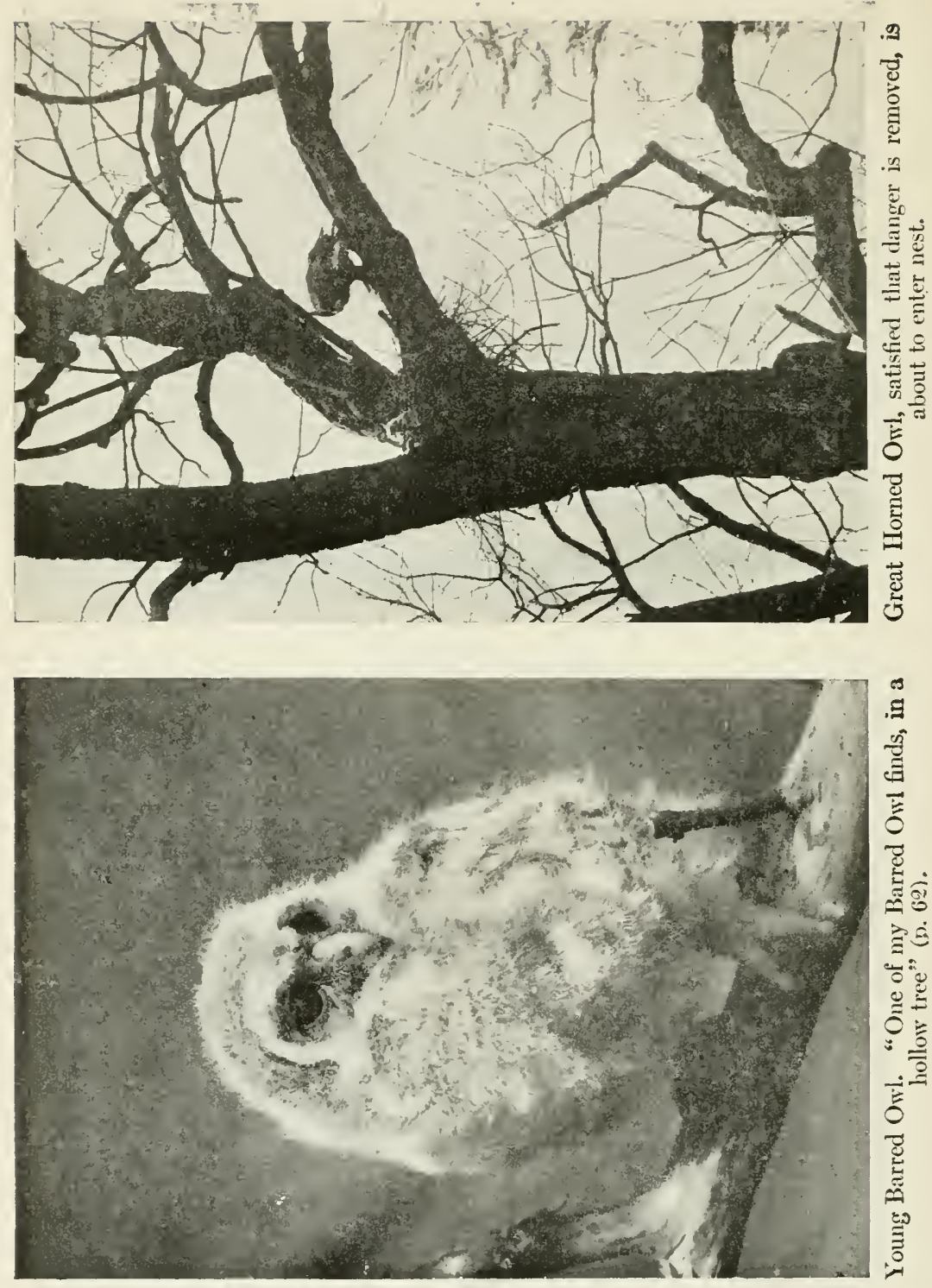


\section{THE BIRD OF NIGHT}

with the suggestion of stormy weather. If they were accustomed to have comfortable nests, we might think that the approaching storm aroused longing for the luxuries of home. But as their homes are most uncomfortable places, and only one of the pair occupies it at the same time, we cannot explain the mystery so easily. The only plausible reason I can think of is that the rise of temperature which accompanies the approach of storm, together with the increasing dampness, brings some conditions of early spring, at which time they are accustomed to nest. Yet hardly has the light spring fancy of love awakened before the cold northwest wind in the rear of the storm area puts it to sleep again. But these are the times to take advantage of, to learn where the owl lives. Don't stick in the house those winter afternoons. A good winter's tramp, or drive, with a bird quest in view, is exhilarating and delightful. Why shouldn't you enjoy the distinction among your admiring and almost envious bird-loving cronies of having yourself found a big owl's nest? I never can forget how I felt, when a boy, attending the Boston Latin School, when one Monday morning one of my schoolmates announced in tones of exultation that on the preceding Saturday he had found a Barred Owl's nest. I had never found any sort of an owl's nest, and that youth became, in my eyes, a real hero, a mighty Hercules, almost. If he had become President of the United States in later years I should have felt but the tiniest fraction of the hero-worship which I then 


\section{THE BIRD OF NIGHT}

accorded him. So, if it be such a glorious achievement in the eyes of some people to find a big owl's nest, and if you know of a tract of woods where you keep hearing the owls hoot in winter, there is no reason in the wide world why you shouldn't be the one to find the nest.

But when is the time to search? Long before most people imagine. In the cold and snowy weather of 1906-7 a friend of mine found one of my old pairs of Great Horned Owls in the pineries of Plymouth County, Mass., doing business at the old stand in the middle of February! A cold sleet storm was raging, but he donned his wet-day uniform of rubber-boots, coat, and hat-and found the big owl sitting on her open platform of sticks high up in a tall white pine on her two nearly fresh eggs. He took these as trophies, and early in March the great birds had twins again, which he allowed to hatch, and enjoyed photographing them as they grew up. That is the true sportsman's spirit, to defy cold and wet, and what a pleasure it is to add such an achievement to the repertoire of one's sporting experiences!

By the last week in February, probably Washington's birthday, every well-regulated family of Great Horned Owls in the latitude of from New Jersey to Massachusetts ought to have eggs, or not later than the tenth or fifteenth of March even up in northern New England or southern Canada. The Barred Owls are a little later, and I have usually found them to have fresh eggs by the first of April, and sometimes as early as the 


\section{THE BIRD OF NIGHT}

middle of March. Both these hardy birds seem to go more by the calendar than by the weather, and at the regular time they will have their nests and eggs, blow it high or low, and be the temperature as bitter as it may. Some years, as the time came around, amid a succession of blizzards I would say- "Surely those owls will not be laying now." But they were, none the less.

Some pairs are earlier or later than others as a regular habit each season, so each owl family has its own schedule and will nest each year at about its own accustomed time. One pair of Barred Owls, for instance, I would always find nesting by the middle of March, but in the next township another pair would not complete their set of two or three eggs till about "April Fool's Day."

The way to find the nest of either of these large owls, when one has found out where they usually hoot, is to go in and make a thorough canvass of whatever large timber is there. Generally they will either occupy the old nest of a hawk, crow, or squirrel, which consists of a platform of sticks in the crotch of a tall tree, evergreen or other, or, if there is a large hollow cavity, pretty well up from the ground, they will use that. If the large owl is brooding in the cavity, she will fly out if the tree is rapped. In case the nest is an open one, she will usually fly out when one approaches, though not always, for sometimes she will wait until the tree is thumped, and once I found a Great Horned Owl which would not leave even then, though I could see her great 


\section{THE BIRD OF NIGH'T}

round face looking out over the edge of the nest. One must get to know the region and explore it thoroughly, not overlooking a single old weather-beaten crow's nest, for that may prove to be just the one chosen by the owl. As in searching for hawks' nests, the very best sign of a nest being occupied is to see bits of downy feathers clinging to its edge. The hawk's down is white, that of owls gray or yellowish. If you can see the down, climb, or get someone else to do it for you if you cannot, for the nest is probably occupied, or about to be, unless, possibly, an owl has merely eaten a grouse up there.

In my book "Wild Wings" I have detailed so many finds of Great Horned and Barred Owls' nests that I must not go into this here, but I will tell about a very remarkable owl's nest which was recently found by a friend, and which I went with him to see.

Not far from Providence, Rhode Island, across the line of Massachusetts, is a little patch of woods, hemmed in on all sides by roads, houses, and a trolley line. Strangely enough, a pair of Barred Owls stayed there, and often during the winter and early spring were seen from the cars in the early morning perched by the roadside. A friend of mine lived near by, and on the first of April he saw one of the owls sitting on a large new nest twenty feet up a small maple, and flushed her by rapping the tree. In fact he had seen her on or about the nest several times before this. It happened that I was in Providence giving a bird lecture, and the result 


\section{THE BIRD OF NIGHT}

was that I went with him on April second to try to photograph the owl, which was quite tame. Getting ready my reflecting camera to snap her as she flew, I advanced toward the nest, when, to my astonishment, a Red-shouldered Hawk fiew out, too far off for a picture. My friend was perfectly dumfounded, for he was an experienced ornithologist and was positive beyond question that a Barred Owl had been occupying the nest, which now contained three hawk's eggs. However, I remembered that another friend had once found a nest in which both a Barred Owl and a Redshouldered Hawk had laid, and hoped that this might be a similar case. Sure enough, it was. Someone shortly after this took the hawk's eggs, but later another friend visited the nest and found it to contain one hawk's egg-probably the last une of the previous set - and two Barred Owl's eggs. It was unfortunate that the nest was in such a public place, for the mixed family were not allowed to hatch, so nothing could be learned of the developments of this remarkable occurrence.

There is another good-sized owl which we are liable to find nesting, the Long-eared $\mathrm{Owl}$, which is somewhat smaller than the Barred Owl. Unfortunately it is not addicted to hooting and is one of the most secretive birds I have ever met. Sometimes I start one out from the shade of a thick cedar swamp, or other dense tangle, but it only allows the merest glimpse as it goes flopping away. It generally occupies some old nest and sticks to it so closely that one is likely to pass it by, after 


\section{THE BIRD OF NIGHT}

pounding the tree, without a suspicion that the sly brown bird is snuggled closely on her eggs.

There is one time at least when this silent bird utterly changes its usual behavior, and that is when she has young, and her nest is invaded. I must tell about one such experience which I had. I was camping one spring with a party of friends in a wild region, on the wooded shore of a large lake. One day, in early June, a furious storm was raging, the wind blowing almost a hurricane directly on shore, raising surf that would have done credit to the ocean. Clad in rubber clothing, we were exploring the woods near camp. At length, as I struggled through the wet branches, I caught sight of what appeared to be a crow's nest, about twenty feet up a small oak. Upon close approach I noticed two brownish knobs or tufts sticking up from the nest and waving in the gale. Then a head was raised, and a shrewd-looking face with a pair of bright yellow eyes was turned toward me. Beckoning to my friends to approach cautiously, I whispered excitedly as they drew near-"A Long-eared Owl, for all the world!" We were nearly under the nest, and had a fine chance for mutual staring. Then I began to ascend the tree, and the owl flitted silently off into the shrubbery. The nest was certainly an old crow's nest of the previous season, slightly repaired on top by the addition of a few sticks and leaves; in it were four owlets and an addled egg. The young were clad in whitish down, with the "juvenal" plumage beginning to show, and were prob64 


\section{THE BIRD OF NIGHT}

ably about three weeks old. As I was examining the odd little fellows, the mother suddenly alighted upon a branch a dozen feet from me, ear-tufts erect, eyes fairly blazing, feathers ruffled, snapping her bill with a sharp clicking sound, and uttering wailing cries which sounded much like the yowling of an angry cat. Indeed she was the ideal of a vixen, as she flitted from limb to limb, with an occasional angry swoop at my head, so near as to strike it with her wings, uttering a harsh exclamation, as she did so, which, I fear, was an owl "swear word." After we all had inspected this prize, we withdrew, and saw the mother go back, almost at once, to her brooding.

By afternoon the rain had about ceased to fall, and, though it was dark and cold and blustering, as we were to leave the locality early next morning, I decided to try to photograph the owl. A neighboring tree, only six feet from the nest, gave an ideal view point for the camera. I had just finished screwing up the instrument, when the owl, who had been making great protests all along, fairly outdid herself. She actually alighted on my head, struck her claws into my cap and really tried to drag me out of the tree. Though spare in build, I proved too heavy for her, and she passed on, assisted by an accelerating shove. Then for awhile I warded her off, but, when I was off my guard, she turned her attention to the camera and alighted on the bellows, into which she sank her claws in vicious frenzy. Finding that she could not drag either of us off, she 


\section{THE BIRD OF NIGH'T}

desisted from the attack. So I attached my linen thread to the shutter, dropped the spool to the ground, descended, and laid my line of communication to a tree some rods away, behind which I hid.

After a little investigation the owl returned to her nest and settled down right before the staring lens. I could now have pulled the thread but for the fact that, owing to the very dull light, I had been obliged to set the shutter for a timed exposure of one second, and the trees were swaying violently, lashed by the gale. In order to see clearly if there was a lull, I crept up close to the owl tree unobserved and waited, thread in hand, for the desired opportunity. Half an hour passed, without a moment in which there was any chance of success. While thus waiting, I was treated to a delicious little episode of owl life. The male owl, a little smaller than the efficient guardian of his children, sailed suddenly through the shrubbery and alighted upon a branch near the ground, hardly ten feet from me. He had seen the camera and was all alert. In one of his fluffy paws dangled a mouse, held by the head, which he had evidently just caught and was bringing to feed his family. He did not see me, and in a moment, satisfied that the camera was harmless, he flitted up to the nest. His mate arose to welcome him and took the mouse, whereupon he flew off energetically in search of another. Being so far underneath the nest I could not see just what happened, but the mother was evidently tearing the mouse, dividing it up 


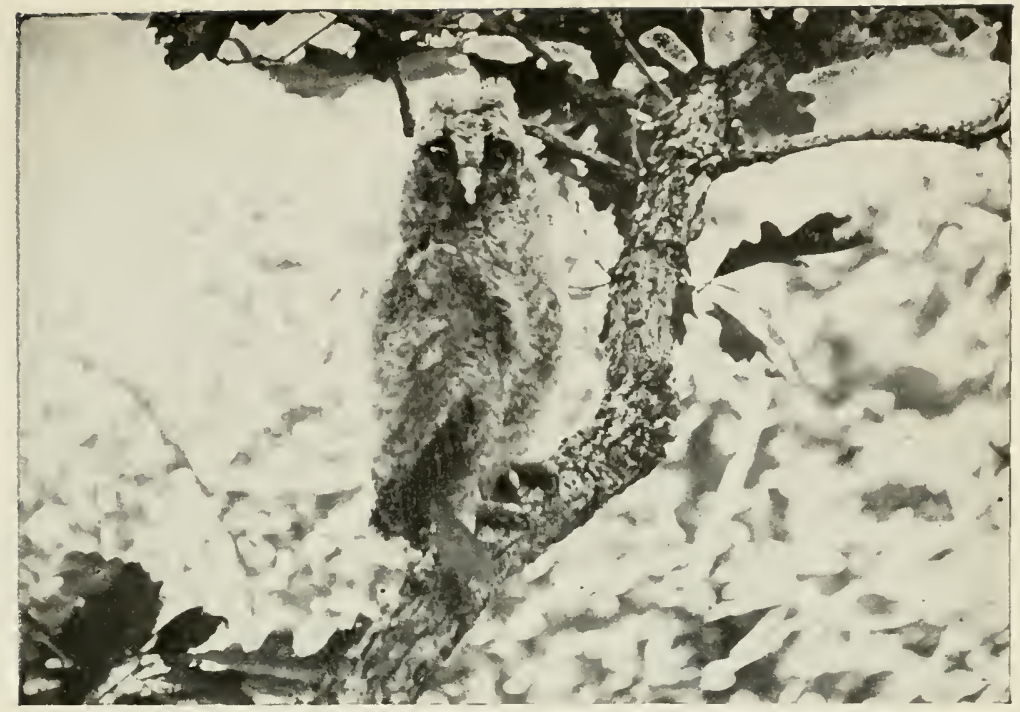

Young Long-eared Owl hiding. "Making themselves look like dead stubs" (p. 67).

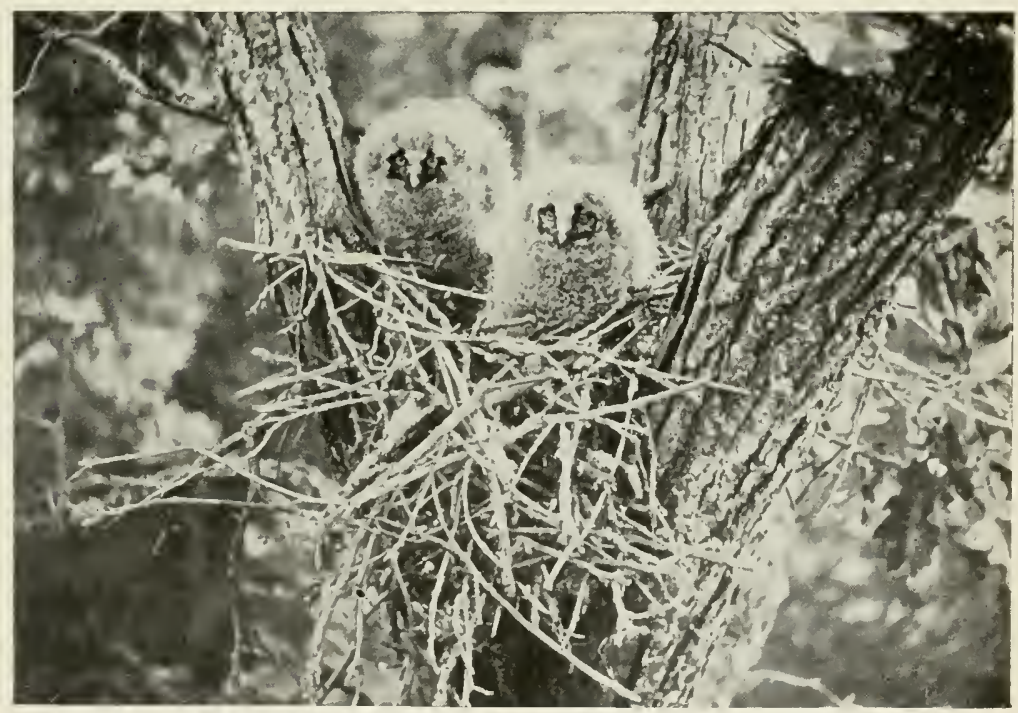

Young Long-eared Owls. "Replaced in nest" (p. 67). 


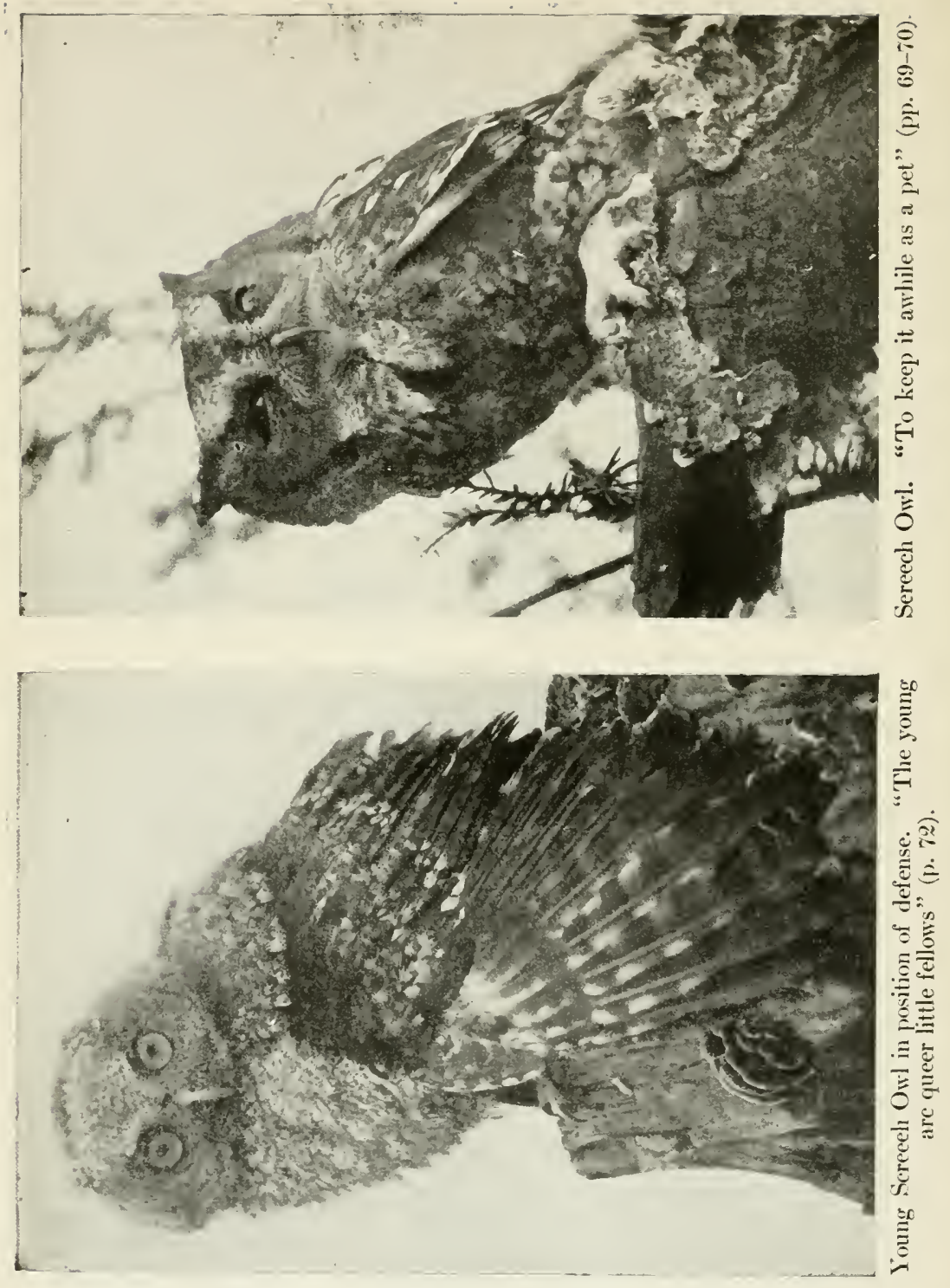




\section{THE BIRD OF NIGHT}

amongst her hungry young, who were moving about actively, each ready for its share. This took two or three minutes, and they all settled down as before. It was fairly maddening not to have light for a snapshot of the six owls as the mouse was being delivered over. And now, as there seemed to be no prospect of anything better, I made several exposures on the old owl incubating, and on the young, before I removed the camera, all of which proved to be blurred by the swaying of the trees.

The next morning was clear and cold and I was there at five o'clock, but the old owl would not return to the nest in the time at my disposal. My chum at length came and fairly dragged me away. We had to drive thirty miles to take a train to a point further south. A week later we returned and the first thing I did was to visit the owls. The nest was empty, alas. But, as the old owl was "yowling" about, I made search and found the youngsters roosting in the trees within a radius of ten rods. As long as they were not handled they remained in their "hiding pose," motionless, erect, feathers drawn tightly together, making themselves look like dead stubs and blending wonderfully with their surroundings. I took various pictures of them in the hiding places, as well as when replaced in the nest. The old bird was still rather aggressively inclined, yet it was very hard to get her picture. Finally I noticed that she often alighted upon a dead treetop before swooping. So I rigged my cumbersome tele67 


\section{THE BIRD OF NIGHT}

photo apparatus up in the tree, focused it upon the branch where I expected she would come, and waited. For a long time she went everywhere but to the right branch, but at length she alighted just where I wanted her and was still for exactly the required half second. Just as the shutter closed the restless head turned, but photographically the owl was mine!

Whenever I think of those Long-eared Owls, I laugh to recall the vision of a man up a tree, a savage owl trying to lift his scalp, making such a tremendous wailing and screeching that a party of dogs lifted up their voices and finally came and stood, howling, too, around the tree, until some men from the neighboring farm, amazed at the commotion, joined in the assembly, and I, to "save my face" and avert the suspicion of insanity, was compelled to add my voice to the tumult in explanation of the comedy.

There is only one other large owl which we are very likely to meet, the Short-cared $\mathrm{Owl}$, a bird about the size of the Long-eared, but without noticeable eartufts. It generally nests further north, but in autumn we are likely to flush it from the ground as we tramp over marshes and meadows, or sometimes moist, bushy pastures. Because it likes such places it is often called the Marsh Owl. I have found their nests in the grass out on the wild prairies of the Northwest.

In the Middle States and in the South one may find the singular looking monkey-faced Barn Owl, which hides itself away by daytime in hollow trees or old 


\section{THE BIRD OF NIGHT}

buildings. But the only other common owl is the little Screech Owl. Were it not for its tremendous cries, resembling the trilling of the tree toad, which are often heard even in towns or small cities, one might well suppose that the bird is very scarce indeed. The Great Horned and Barred Owls do not mind the broad daylight, but our little friend Screecher prefers to hide in a hollow tree, or even a building until the dusk of evening. If discovered by day, it appears dazed and torpid, and generally refuses to come out of its hole, unless dragged by force. I have often found it in winter by examining the ground or snow under woodpeckers' holes, or in hollow limbs, in orchards or woods. When I find rounded masses of bones and hair, called pellets, the indigestible remains of its food which the owl throws up, I climb to the hole above, put in my hand, and pull out the owl, which usually is too sleepy to make much resistance.

One day in early autumn I took a walk out into the country. At the edge of some woods I noticed an old apple tree with a hollow trunk and a hole about as high up as my head. I thought it a good place for a Screech Owl, and so I went and looked in. Something was in there sure enough, for I could see two round shining orbs. After my eyes became used to the darkness I could see that they were the eyes of a Screech Owl, so I put in my hand and found I could just reach it. It did not struggle or bite as I pulled it out, and I put it in my pocket and rode home with it on my bicycle, to 


\section{THE BIRD OF NIGHT}

keep it awhile as a pet. Captive owls do not get very tame, but they feed heartily on raw meat and do well if they have room enough to exercise.

Another time I was taking a bicycle ride when I came across a boy who had caught one of these owls in the same way in his orchard. I happened to want one then to study, so I paid him for it, put the owl in my pocket, and, taking the precaution to pin down the lapel, started homeward. When I was about halfway back, I felt to see how the owl was getting on, and found, to my chagrin, that it had escaped?

Last winter one of these owls spent his sleepy days in a hole in a tree right on the main street of the village, about twenty-five feet from the ground. At dusk it would poke its head out of the hole and gaze around for awhile, then crawl out and perch on a limb nearby for a few moments before fying off on a mousing expedition or to catch a fat English Sparrow-for its breakfast, I suppose we would call it, as our night is the owl's day. The boys soon discovered the owl's retreat, and would throw snowballs at the hole, to make the big-eyed bird come to the door. It would only look out, though, toward night. Some of the boys were for climbing up to catch it, but Ned persuaded them to let it alone.

In bitter winter weather the poor little owls had a hard time of it, for they, as well as some other kinds of owls, do not migrate very much, and they crawl in almost anywhere to try to keep warm. One of them \% 0 


\section{THE BIRD OF NIGHT}

used to occupy my next door neighbor's bird box. One Sunday morning the sexton was starting a fire in the church furnace when he discovered a poor little Screech Owl, blinking in the smoke, and pulled it out just in time to save its life. It well deserved to be spared this or any disaster, for it is a fine thing for a town to have resident Screech Owls to keep down the English Sparrow nuisance. There is a village not far from where I live where one winter a Screech Owl stayed all the time in a thick spruce right by the post office and ate so many sparrows that by spring there were hardly any left. They are great mousers, too, as are most kinds of owls, and no one ought to kill them. The one exception is the Great Horned Owl, which is liable to make great inroads on poultry, if it once finds its way to their quarters, though generally it stays in the woods and feeds mostly on rabbits, skunks, and, unfortunately, the Ruffed Grouse.

A friend of mine has a nice aviary of domesticated wild geese and ducks, a tract of meadow close to the brook beside his home, fenced in with wire, but not covered overhead. This summer he began to lose his ducks; every morning one was missing. Finally, when he found a beautiful Pintail drake dead and partly eaten he decided that the intruder must be the Great Horned Owl which hooted off on the mountain. So he put up a fifteen-foot pole at one corner of the yard, with a steel trap set on top of it. The owl will always alight on some commanding perch and look around before 


\section{THE BIRD OF NIGHT}

pouncing. He expected that the owl would alight on this stake in the trap, and sure enough, at daybreak the next morning, the guilty owl was hanging ignobly from the pole, caught by one foot. A charge of shot put an end to its thieving career. But this is the exception, and most owls deserve better treatment. It would not be fair to hate all boys because one boy was mischievous, would it, Ned?

The Screech Owl lays four or five eggs, which are white, like all other owl's eggs, about the middle of April, at the bottom of a cavity in a tree. It likes an old orchard very well, but is just as likely to locate in the woods. Seldom is there any sign of occupancy about the hole, and the owl will not show herself, however much one may pound the tree. The nest may be right by one's home, but it is hard to find. The only way I know is to keep looking in likely holes, especially in a neighborhood where the owls are heard at night. I have found several nests, but only because I looked in several thousand holes. The brooding owl is as tame as a sitting hen, and, like them, some will peck and some will not, when you pull them off their eggs. The young are queer little fellows, at first covered with whitish down, which changes to a soft gray plumage. Later, when fully feathered, it may be either red or gray in general hue, and we do not know any satisfactory reason for this variation, any more than why some people have brown hair and others red.

There is another little owl, even smaller than the 72 


\section{THE BIRD OF NIGHT}

Screech Owl, which we may happen upon some time. It is called the Saw-whet Owl because its love song in the spring reminds one of the rasping of sharpening a saw. Most specimens are seen in fall or winter, in bushy pastures or cedar swamp thickets, or are found dead in severe weather about houses, whither they have been driven in a last vain hope of finding a mouse to keep them from starving.

A hunter whom I knew caught one of them in a steel trap set for mink in the woods in March. He had the little sprite in a room in his house, where it was flying around actively, alighting on the furniture. I was glad enough when he offered it to me, and took it home in a box, to photograph and study it. The next day I silould have secured a series of pictures of it from life, but a furious easterly gale was raging with a pouring rain, and it was very dark. As the conditions were most unfavorable, I waited till the next day, and was sorry that I had not done the best I could even in the storm, for the little creature lay dead under its perch, and I have never yet had another chance to photograph one.

Had I begur to hunt birds with the camera a little sooner than I did, I should have had a splendid opportunity to picture this rather rare owl, for I was so fortunate as to find a nest eleven years ago. The bird usually goes further north to breed, and this was the only nest I ever have seen. I described the adventure quite fully in "Wild Wings," but may say that it was 


\section{THE BIRD OF NIGHT}

in a Flicker's hole, in a pine stub, and the bird was so tame that I could have done almost anything with her. She had five incubated eggs on the eighteenth of April.

However, I did manage to take a picture of a Sawwhet. Three of us were out for a tramp and came to a horse shed at the edge of the woods. It was open, so I looked in, and there sat a tiny Saw-whet $\mathrm{O} w \mathrm{l}$ on a beam close by. The owl and I were face to face, and we both just stood and stared at each other in blank amazement. Presently I recovered my presence of mind and backed off to get my camera. But the owl likewise came to itself, and, flying across the stable, alighted at a hole in the partition which led into an outer shed which was entirely open on one side. If once it got out there, it was a "goner" for me.

Seizing my camera and tripod which I had stood up outside the door, in as few words as possible I told Ned what was up and sent him around on the run to keep the $\mathrm{O} w \mathrm{l}$ from flying through. When he appeared the owl faced backward toward me, seemingly undecided what to do. Calling to Ned to wait, I planted the camera in the greatest hurry, focused on the bird, and exposed two plates, long-timed, of course, in such a dark place, but fortunately the queer little subject kept quite still.

Just as this was done, the owl decided to flee from Ned, and came back into the shed. Ned stopped up the hole, and then we all tried to catch Mr. Saw-whet, one of us guarding the entrance, as there was no door. 


\section{THE BIRD OF NIGHT}

I threw my cap over the owl and it fell to the floor. We each made a grab for it and there was a general mix-up, but somehow the bird which so many people think is blind by daylight dodged through the array of legs and hands, flying out of the door. "Well, I never!" I exclaimed in disgust. "What made you so awkward, Ned?" "Yes, how about yourself?" he retorted.

Severe winter weather is liable to bring certain rare boreal owls to us from the Nortl. The best known and most beautiful of these is the Snowy Owl, that splendid white bird which we associate with the polar bear and icebergs. There is apt to be a flight of them in early December, if at all, and one is liable to meet a specimen anywhere inland, though the seacoast is the best sort of region to find them. I have met but one in my life, on a salt marsh. Another greater rarity is the Great Gray Owl, a Northern species closely related to the Barred Owl, but larger. I have never seen it alive.

The severe winter of $1906-\gamma$ brought to us many Northern birds. On the twelfth of November, 1906, a lady was driving along a road in the outskirts of the town where I live. She came upon an Indian woman who was examining something lying in the road. It was a small owl which had somelow perished. Thinking it a "cuic" little thing, she brought it to me to have it mounted. I was not at home, but met her at the post office. "Could I get you to stuff it for me?" she asked. "Really," said I, "I don't see how I can. I am just going away, and am very busy." But she looked so 


\section{THE BIRD OF NIGHT}

disappointed that I relented and took it, knowing that it would keep a long time in the cold weather. It was getting dark and the owl appeared to be a Saw-mhet. I stuffed it in my pocket, and on reaching home tossed it up on a shelf in the woodshed, where it remained for weeks. Finally I got it down one afternoon and was at once impressed by its size, for I now saw that it was nearly as big as a Screech Owl. "That's no Saw-whet," my wife exclaimed, as I rushed for the reference books. "Richardson's Owl!" I shouted. "What a find!" It proved to be the second one ever taken in Connecticut, the only other having been recorded by Dr. William Wood, away back in 1861. To this day I have not gotten over the sensation which comes over me when I think of how near I came to missing such a rare find. 


\section{CHAPTER V}

\section{STRANGE BED-FELLOWS}

\section{(Cuckoos and Kingfishers)}

F CAN'T see for the life of me," said Ned one day, as we were driving home after photographing a Black-billed Cuckoo on her nest, "why in the world the scientists have put the cuckoos and the kingfishers together in the same group in their classification. Why, anyone can see that they are as different as day is from night. 'They both wear feathers and fly, and that is about all the likeness I can see!"

"We mustu't be hard on the poor scientists," I replied. "They have a hard nut to crack. There are a number of groups of species which are so different that they do not know what to do with them. Formerly they just gave it up and dumped them all into one miscellaneous rag bag-Picarian or woodpecker-like birds they called them, nicknaming them after the largest of the groups. Now, however, they have found a better home for each of the poor orphans, all except the unfortunate cuckoos and kingfishers and some foreign tribes, so they fixed up a smaller catch-all and named it after the cuckoos -Coccyges, the Greek for cuckoos." 


\section{STRANGE BED-FELLOWS}

"Well," said Ned, "I should think that such strange bed-fellows would get to fighting, but I suppose that they don't realize that they are in such close quarters."

This scientific discourse grew so absorbing that, as we approached the railroad track I forgot to "look out for the engine," as the old signs used to say. Just as we were about to cross, I saw the evening express train swiftly rushing down upon us, only a few rods away. I had to think quickly what to do. If I stopped right there, the horse would certainly shy down the embankment, though, of course, we could jump out. But I thought we could get across barely in time, so I plied the whip, and with a leap we went flying over, having just a few yards to spare as the train thundered past. We were so much excited that we forgot all about the Coccyges and set to berating the engineer for not having blown the whistle on approaching the grade crossing. But birds are very fascinating, and ornithology was not knocked out of us for very long, though we resolved to put prudence ahead of it in future when crossing the railroad track. And now that we are safely escaped we will return to the cuckoos.

The nest which I had just found was in a dense thicket of bushes, a few rods back from the road which passed near the pond, and about opposite the latter. It was the seventh of June, and we were tramping about in a large tract of scrub and briers, searching for birds' nests. For some time we had had no especial luck, until, as I poked my head into this particular thicket, 


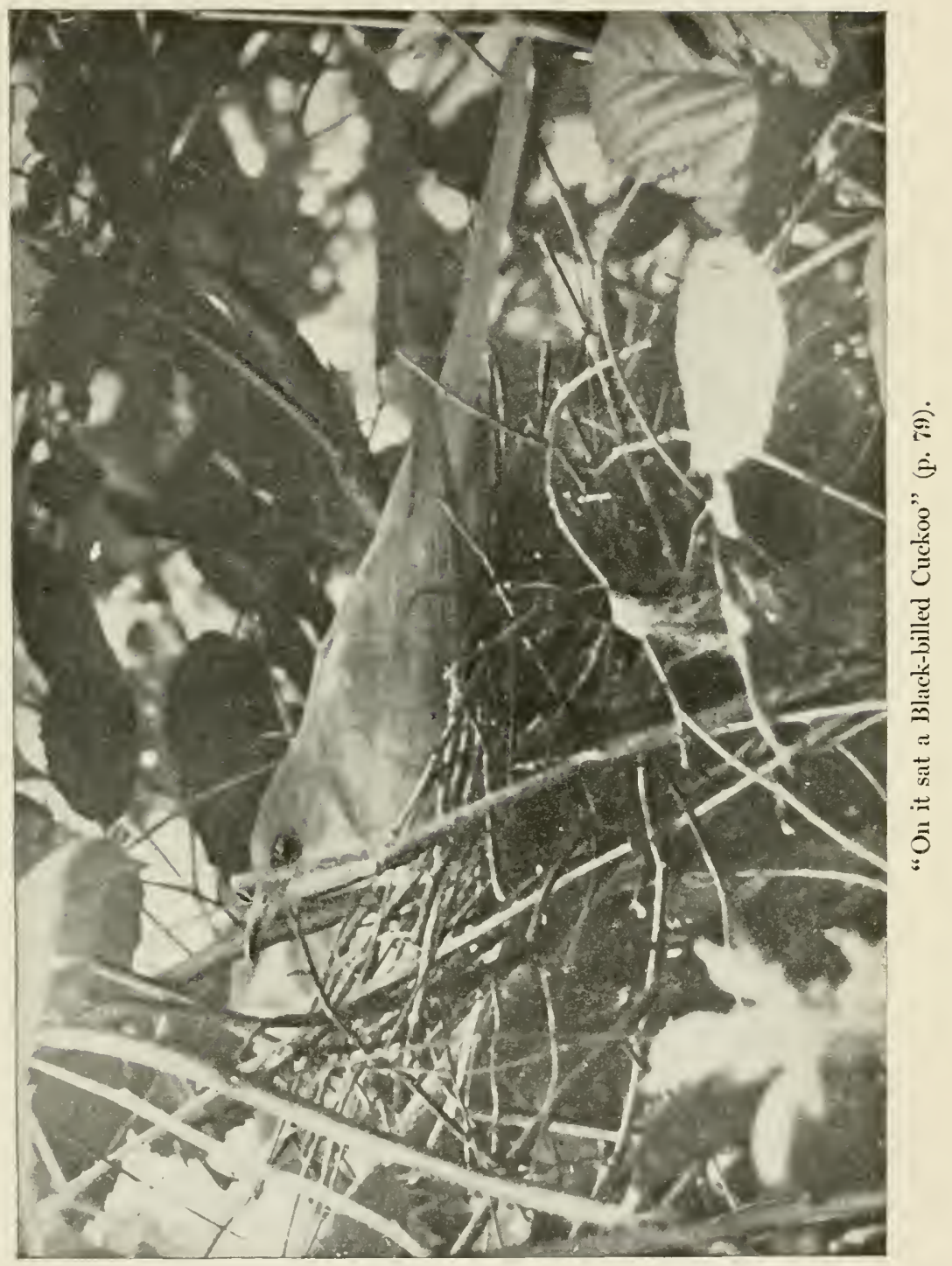




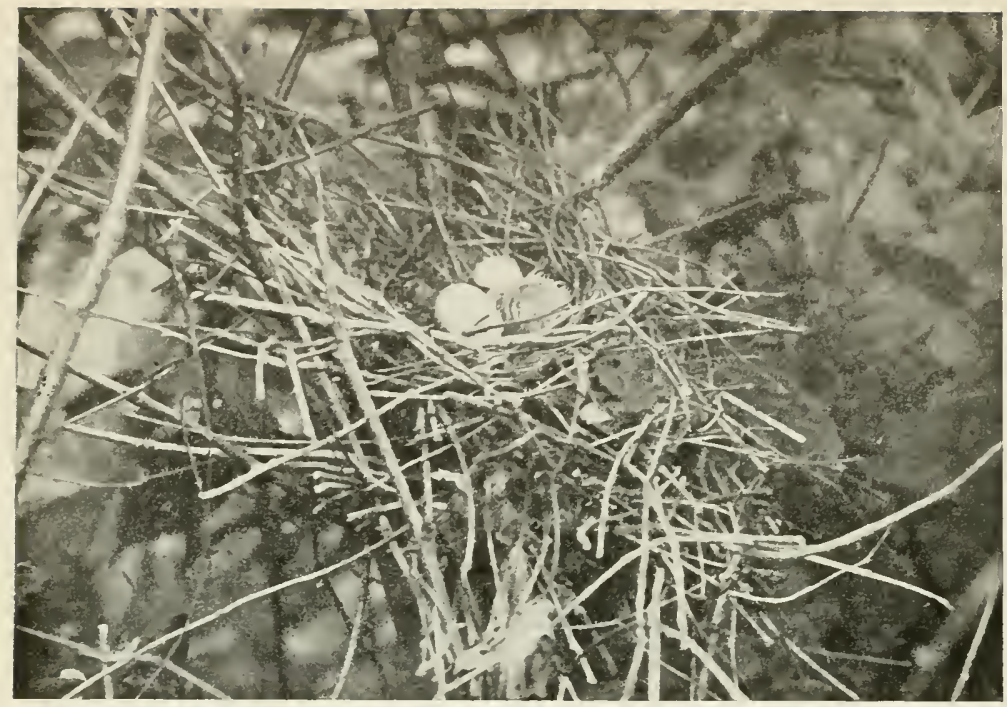

Nest of Black-billed Cuckoo. Showing the newly hatched youngster with its blue (ap (p. 79).

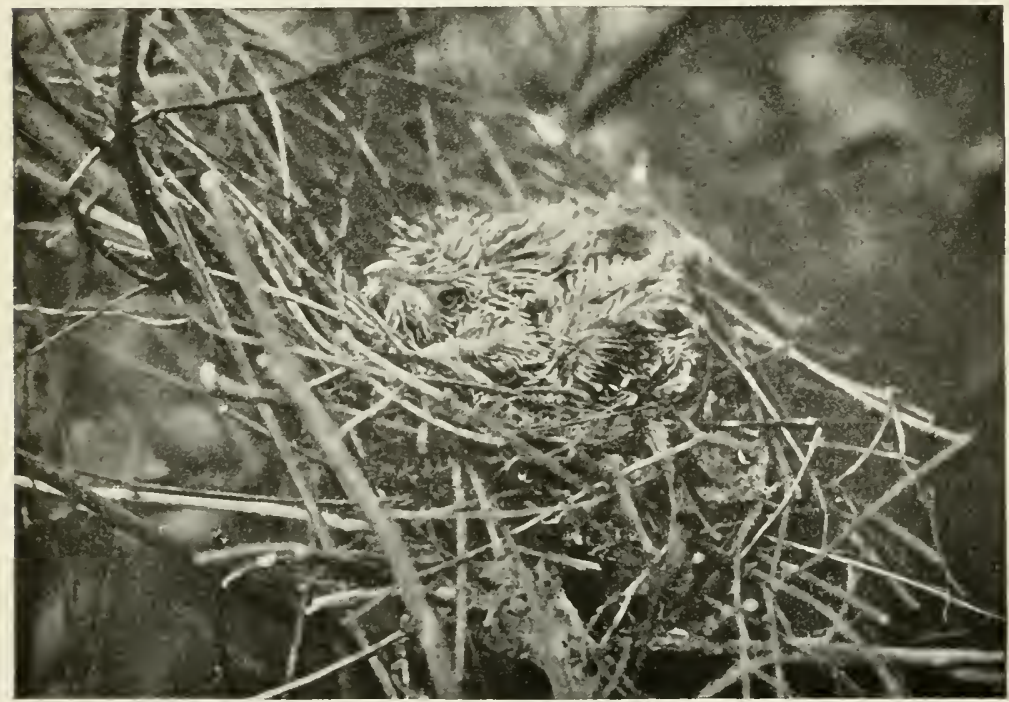

Young Black-billed Cuckoos in nest. "Bristling with pin-feathers" (p. 80). 


\section{STRANGE BED-FELLOWS}

there right before me I saw a flimsy nest of twigs and stems. On it sat a Black-billed Cuckoo, gazing at me in alarm with her large hazel eyes which were bordered by red eyelids. When Ned came up I made signs to him to keep very quiet, so he looked on while I set up the small, long-focus camera on the tripod, with the eighteen-inch lens. Fortunately there was a small opening through the bushes to the nest, with nothing much to obstruct the view, and, after taking one small picture of the bird from where I was, to make sure of something, I pushed the tripod and camera nearer and nearer. At each halt I made another exposure and secured a larger image of the bird on the plate. Of course I was very careful not to rustle the leaves or step on a dry twig or make any sudden motion. The bird actually let me photograph her within four feet before she slipped off the nest and disappeared in the shrubbery. No wonder she was tame, for it was just hatching time. There was one pipped egg in the nest, and one newly hatched young one. When it had crawled out of the shell, it had taken with it the rounded end, which it wore on its head as a close-fitting blue skull-cap, and it certainly looked very comical. While I was at work with the camera, Ned's sharp eyes spied out a Wood Thrush sitting on her nest in a low sapling just outside the brier thicket, not more than twelve feet from the cuckoo's nest.

A few days later we visited Mrs. Cuckoo again, and found her brooding. She was in a better position, with 


\section{STRANGE BED-FELLOWS}

the whole of her long tail showing, so I took some more pictures of her, as before. When she left, I photographed the two youngsters in their rude, hard cradle. Ugly brats they were at this stage, with great ungainly beaks, all out of proportion to their size, and bristling with pin feathers. The nest, as usual, was almost flat on top, and somewhat tilted over besides. It always seems a wonder if the young cuckoos succeed in hanging on to the nest. That they sometimes do not, I know for a fact, for soon afterward I found this nest deserted, and a few years before I had watched another nest of this species in the same locality, down by the pond in a bushy swamp.

This nest also had two small young, which, after a severe thunder shower and wind, disappeared. Their home was a most unusual one. It was in an ordinary situation, six or eight feet up a sapling. But near by in the swamp was a willow bush which was just getting past its flowering by the middle of May, when the cuckoos began to build. Instead of picking up sticks and making a platform so frail that one could see the eggs through it from below, these birds had constructed a big, soft, nest, very deep, though flat on top, almost entirely out of willow catkins and down. They deserved better fortune than to have their young blown out of such a palatial nursery-for a cuckoo!-and drowned. But this is the lot of many a young bird, even from the best of bird homes.

We have two kinds of cuckoos-Black-billed and 80 


\section{STRANGE BED-FELLOWS}

Yellow-billed, which are hard to tell apart, unless one gets very near them, which is not easy to do. They are shy, retiring birds, and keep mostly in the thick foliage. Bird students seldom have a better chance to examine a cuckoo in life and see how useful a tribe these birds are than did a certain company of young ladies. I was giving a bird lecture at Bradford Academy, Mass., and the next morning took an early bird walk with a party of the girls and a teacher. Beside the path was a wild cherry tree which was stripped bare of foliage and contained the nest of the despoilers, some sort of canker worm or caterpillar. Perched beside this was a Blackbilled Cuckoo, breakfasting. We were all within twenty feet of it, and watched it for some minutes eat worm after worm, which it took from the nest. If we could only raise cuckoos enough, we might conquer the gypsy moth, that most expensive pest.

Were it not for the loud, harsh "cow-cow" notes of the cuckoos, we certainly should think them much rarer than they are. But they are both all too scarce, and generally the Yellow-billed kind has seemed to me the rarer of the two. When I have hunted for their nests I usually have had no success. But now and then I have happened upon a nest of either kind when I was least expecting it. Though I have found more nests of the Yellow-billed in old, retired orchards, I have also found the Black-billed breeding in such places, and I am not sure that they differ materially in the sorts of places which they frequent. 


\section{STRANGE BED-FELLOIVS}

The very opposite in temperament is the Belted King. fisher, our only species of this interesting sub-order. No bird is more conspicuous than this most royal fisherman of all our small land birds, sounding its loud rattle as it flies over land or stream, or perching on some conspicuous stub by the shore from which it can watch for the small fish to rise to the surface. Suddenly it plunges headlong into the water with a loud splash, and, emerging, flies off with a triumphant announcement, like the hen, which tries to publish world-wide the glorious fact that she has laid an egg.

Sometimes, though rarely, the kingfishers are seen in the land of ice and snow during the winter, but at any rate they come back early, toward the end of March or in early April. Before long they get to work digging their nesting burrows in some gravel bank not far from water, though not necessarily right by the shore. Often they choose a cut in a road or railway, or a spot where a farmer has excavated for sand or gravel. They are great diggers and go in as much as six feet, with turns in the tunnel, too, to avoid rocks. At the end there is a wider chamber or pocket where six or seven good-sized white eggs are laid on the earth, surrounded by an ever-increasing pile of fish bones, the remains of the regular fish dinners.

In years past I had seen various kingfishers' holes, and had dug one out to examine the nest and young, but I had no photographs. So, when I realized that a certain chapter must be written and needed king- 


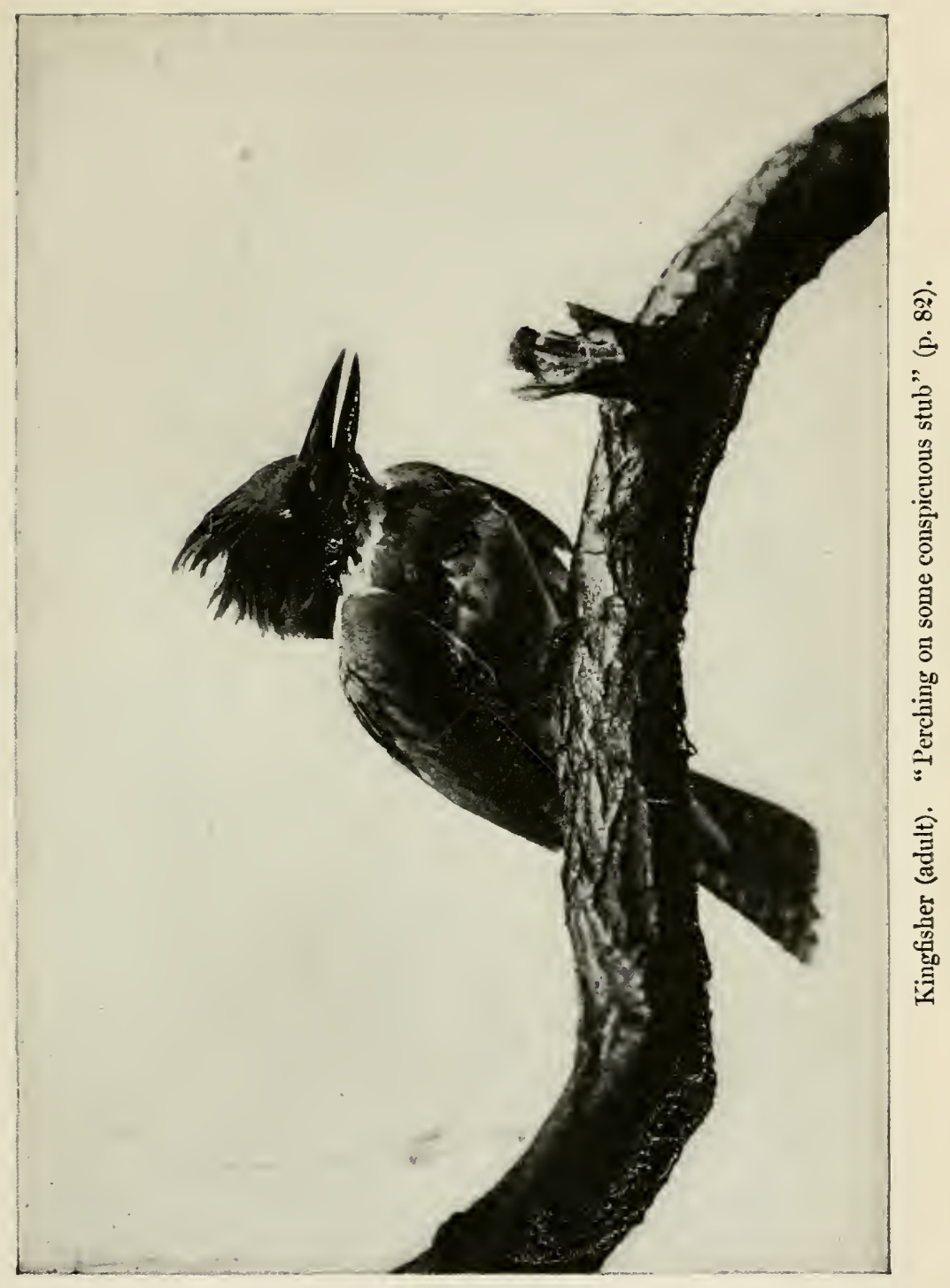




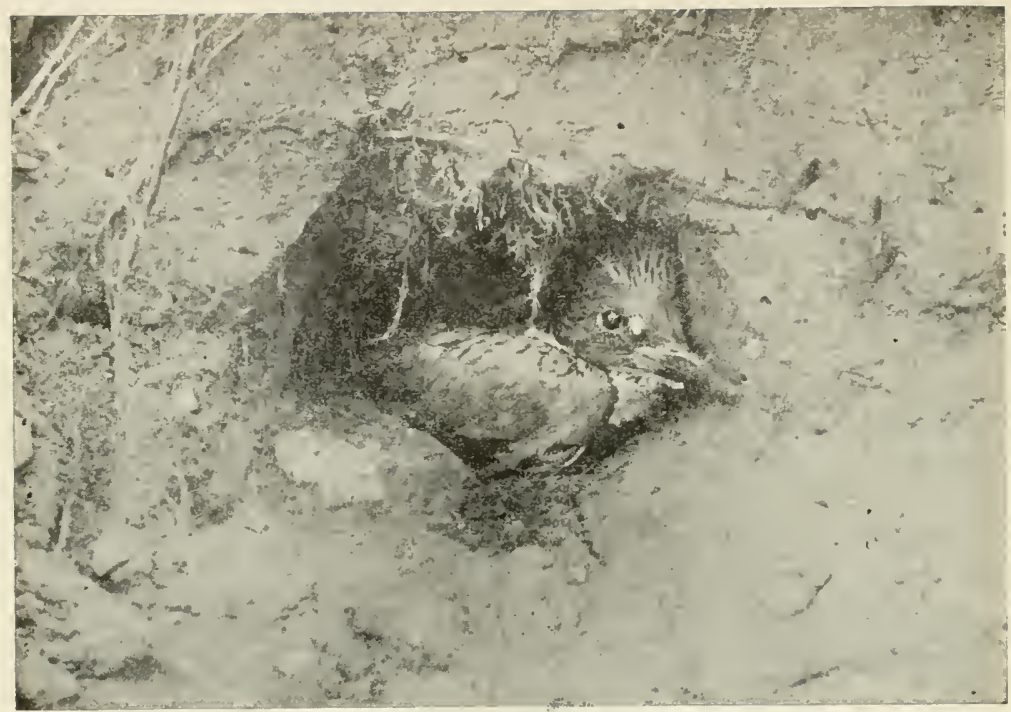

Young Kingfisher leaving nest-burrow. "Immediately it tried to get out" (p. 84).

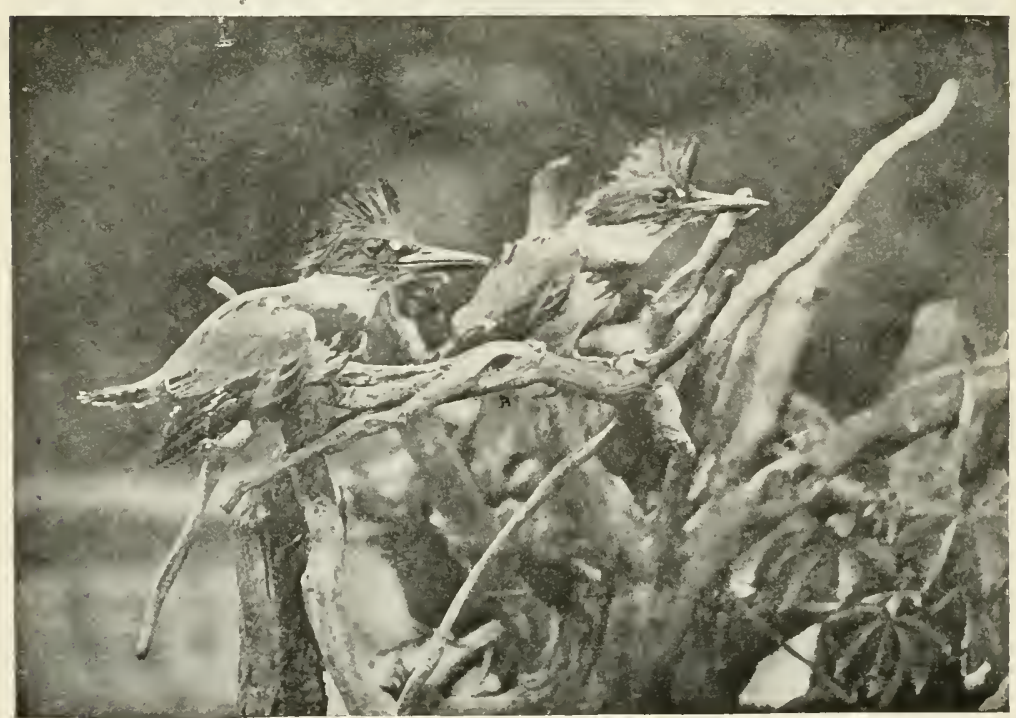

Young Kingfishers. "On an overturned tree-stump" (p. 85). 


\section{STRANGE BED-FELLOWS}

fisher adornments, I had to hustle to get some pictures, before it was too late in the season. Ned was a good fellow to consult on such important business, and he remembered two places where he had seen kingfisher burrows, so we rounded them up at once. The first was in a pasture, where road makers had dug out gravel, and left a steep bank. There was no burrow there this year, though later in the season I saw where the pair had nested, in a bank about half a mile further on, by the roadside. The other location was near the pond, where the railroad had been cut through. It did not take long to discover two round clear-cut holes of just the right size-kingfishers' work without a doubt. One did not go in very far, as the birds had struck rock. So they had tried again a few feet away, and this one was evidently complete, for it went in further than I could reach. No birds were in sight, yet I felt sure it was a new burrow.

It was so late in the season that I feared the young had already flown. So the next day, the twenty-sixth of June, as I was about to drive by this spot with my wife and baby girl, I took along a shovel, and hitched the horse by the roadside at the nearest point to the burrow, telling my wife-with some misgivings-that it would only take me a few minutes to dig in far enough to find out whether the nest was occupied, and if it was I would take the photographs later. I took the camera along, though, to photograph the site before I disfigured it. After taking the picture, I started 


\section{STRANGE BED-FELLOWS}

to dig, when suddenly a kingfisher popped out its head and was just preparing to fly away, when I grabbed it. "Aha!" thought I, "here is the mother bird, and I'll have her picture too!" Just then another bird came out of the burrow, almost like a cannon ball, and flew off before I could try to stop it. So the father bird was in there also? Then, to my astonishment out went another, and then another tried it, but this one I caught, putting both into my camera case. A regular eruption of kingfishers was in progress, a miniature Vesuvius in action. Really I cannot tell how many kingfishers came out; I lost count in the excitement; but I think it was eight, possibly only seven. Of course I knew now that this was the brood of young ones, fully grown and fledged, in beautiful plumage. I had caught four; the others flew over to the pond, all but one which alighted on the railroad track. Fearing that a train would come along and kill it, I tried to drive it off, but it kept flying along the rail and alighting on it, and I had to chase it a quarter of a mile before it flew off to one side.

Here was a pretty quandary. A heavy thunder shower was fast approaching, the wife and baby were there in the woods, but if I left the young kingfishers, it would probably be all up with my kingfisher photographs for this chapter. So I thought I would get a few, any way, and hurried to focus the camera on the entrance to the burrow, after which I put one of the young back into the hole. Immediately it tried to get 


\section{STRANGE BED-FELLOWS}

out again, but the lens caught it, and then my hand, this operation being repeated several times. Then I put two of the lively youngsters up on an overturned tree stump and roots, which the workmen had dug out when they straightened the railroad. Like most young birds, they acted in an exasperated manner, delaying me while the shower came nearer and nearer. I was determined, now, to get this picture at almost any cost, knowing that with a top buggy my family would not be quite drowned. Finally I made my last of several exposures just as the first of the big drops began to fall. Under the rubber cloth I packed away my camera. Then I put the young birds back into the burrow, waiting a moment to drive them back as they tried to come out. Then, gathering up my things, I raced for the buggy in the increasing downpour. The family were not there. In alarm at the approach of the tempest they had put for the next farmhouse, where I found them when the storm had nearly spent itself. They were none the worse for it, nor was I, though wet and plastered with mud. But I am glad that I did it, because I have the pictures to show for my pains.

This episode amused Ned very much. He wished he had been present to see it all, and I certainly had earnestly wished that he was there to help me manage those contrary young birds. I could have finished then before it rained. Sometimes, in photographing birds it is best to be alone, but again an assistant is an exceedingly great convenience. But Ned had his 


\section{STRANGE BED-FELLOWS}

innings before very long, and had the fun all to himself at that. He was fishing on the river bank, sitting among some nettles. A very small fish got hooked, and before taking it off he allowed it to stay in the water and watched it as it tried to get away. But other sharp eyes were watching, too. A kingfishex had been flying about, catching a fish now and then. It spied the fish that was hooked and became so interested that it forgot Ned. What should it do, before deciding to pounce on the fish, but alight on the fishpole which Ned was holding, out near the end. Ned was so surprised that he almost dropped the pole, but, recovering his presence of mind, hung on and enjoyed the strange proceeding. 'The bird looked big and felt very heavy, so much so that after about a minute, which seemed like quite a long time, Ned could not help dropping the pole a little, and the eager fisher, which was about to dive after the fish, became alarmed and flew away. I showed Ned a stuffed kingfisher, but he says that his kingfisher was larger and handsomer, better in every way. 


\section{CHAPTER VI}

KNIGHTS OF THE CHISEL

\section{(Woodpecliers)}

TED," said I one day, "I wish you'd keep your eyes open for a good woodpecker's hole situated so that I might be able to get some pictures of the old bird at the entrance. You know we've got pictures of some of them eating suet, but I haven't anything about their nesting, and we must have it for the book."

"What kind you want?" he asked, stopping for a moment his operations on his broken butterfly net.

"Why, an Arctic Three-toed, or a Pileated, would suit me tiptop," I rentured.

"Oh, you go chase yourself!" exclaimed the fancier of the "butterfly étude." (Ned was as fond of music as of birds and butterflies.) "Do you think I'm going to climb the North Pole to find those rare things? Give me something easier."

"All right," said I. "I'll relent and give you the commonest kind there is, the fellow so well known that he has any number of names-Flicker, Yellow-hammer, High-hole, or, if you want to be more swell, Goldenwinged Woodpecker. Do you think you could find one?" 


\section{KNIGHTS OF THE CHISEL}

"I'm sure I can find Flickers' nests," he responded, but maybe they'll all be up in rotten stubs a mile high. "But I'll see what I can do."

So we both were rivals as to who would do the best. I found the first, because I was out the most, while poor Ned was shut up in school studying Latin, which he doesn't enjoy overmuch, yet finds it useful in learning the scientific names of the birds. $\Upsilon$ tell him that if he doesn't get his Latin lessons those big long bird names will stick in his throat. It needs considerable vocal lubrication from classical study to call a Redheaded Woodpecker a Melanerpes erythrocephalus, but it can be done, for Ned has accomplished it. But we will let him escape from school this fourteenth of May and drive five miles to see a few hawks' nests-Broadwinged, Cooper's, and Red-tailed, all within less than a mile, and incidentally my Flicker's hole. The bird was still digging it out, and as we approached we could see some long thing sticking out and jerking up and down like a pump handle. It was the Flicker"s tail! She had chiseled into the chestnut stub with her powerful bill deep enough to hide all of her but her tail. And she was working hard, too, but she did not keep it up long enough to violate the rules of the labor union-"the I. O. K. C"-Ned and I call it, or the "Independent Order of the Knights of the Chisel." They do not allow even an eight-hour day on a house contract, but on the other liand compel a frightfully long service in chiseling for the festive grub. This 


\section{KNIGH'TS OF THE CHISEL}

bird was building only about ten feet up, at the edge of the Cooper's Hawk grove, and, though there was no other tree close by on which to rig the camera, I thought I could manage somehow to get a picture, if nothing better turned up.

But we discovered plenty more nests. One day I found as many as half a dozen in a tract of woods where the trees were dying from an excess of water. Unfortunately every one of them was high up. Another nest was in the midst of unusual life and activity, though in lonely woods well up the side of a hill. The Flickers had dug a hole twenty feet up a dead chestnut stub. Fifteen feet higher, at the top, a pair of flying squirrels had young in the Flicker's last year hole. At the base of the stub, under some rocks, were two entrances to an occupied fox burrow. Evidently the young foxes played there, for the ground was thoroughly trampled, and at one front door were turkey bones and feathers and some fresh green leaves. IVithin a few rods a pair of Oven-birds had a nest on the ground, surprisingly well concealed, for even the foxes had not found it. Besides this, a Red-eyed Vireo couple had built in the fork of a sapling, just out of Reynard's reach, and a somber-hued female Scarlet Tanager brooded higher up, out on the extended branch of an oak.

But after all Ned beat me, for he found the best nest of all, and handy to home at that. It was in an apple tree in an orchard, on the west side where it had some 


\section{KNIGHTS OF THE CHISEL;}

of the late afternoon sun, up in the spreading part of the tree, with branches in front of the hole where a camera could be remarkably well hidden. So, one bright afternoon, I made a visit there. Madam Flicker flew out, and I screwed up the small camera in the favorable spot, covering it with green branches, and then, having attached the thread, hid behind the next apple tree. In a short time I heard the Flicker's "yawp." She flew from a tree near by directly to the entrance of the hole, where she paused for an instant, giving me a good chance for the exposure, and then went in to her eggs without noticing the camera, or paying more than momentary heed to the click of the shutter.

I walked off for a few minutes to let her warm her eggs, and then, as I approached, a Flicker flew from the tree. I changed the plate and then waited and waited, but no bird came back. This was puzzling, for everything seemed to be right, and I was pretty well concealed. At last, just as I was about to go to see if anything was wrong, a Flicker stuck its head out of the nest hole, and then withdrew it, after I had pulled the thread and got a good picture. I went to the camera but no bird flew out. "Can it be," I thought, "that the bird was a full-fledged young one, for it is only the eighth of June?" However, I decided to make sure, so I put my hand and arm into the hole. I could feel a bird, but it did not peck or bite, so I drew it out by the bill, though it hung back some. It was the mother 

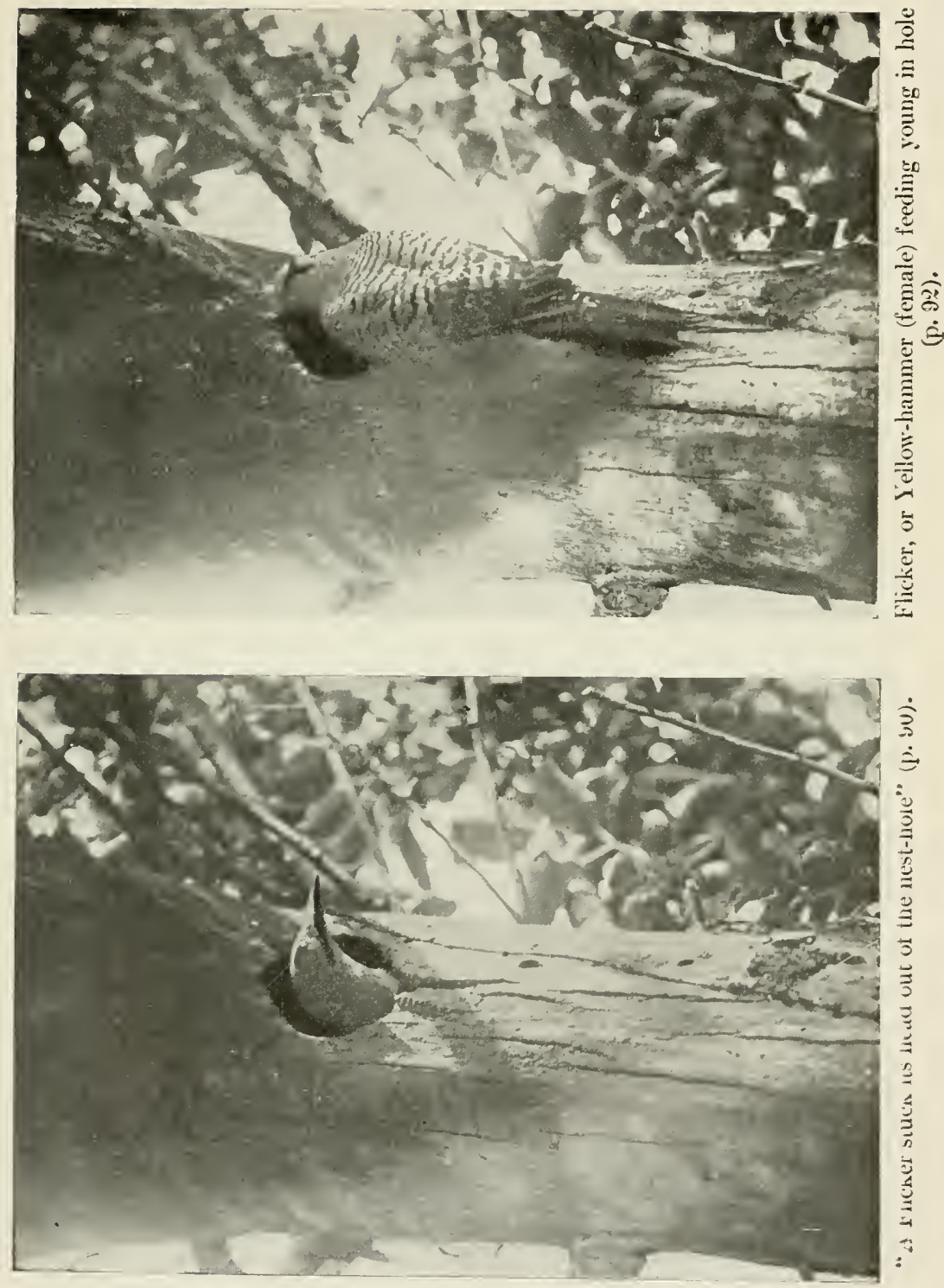


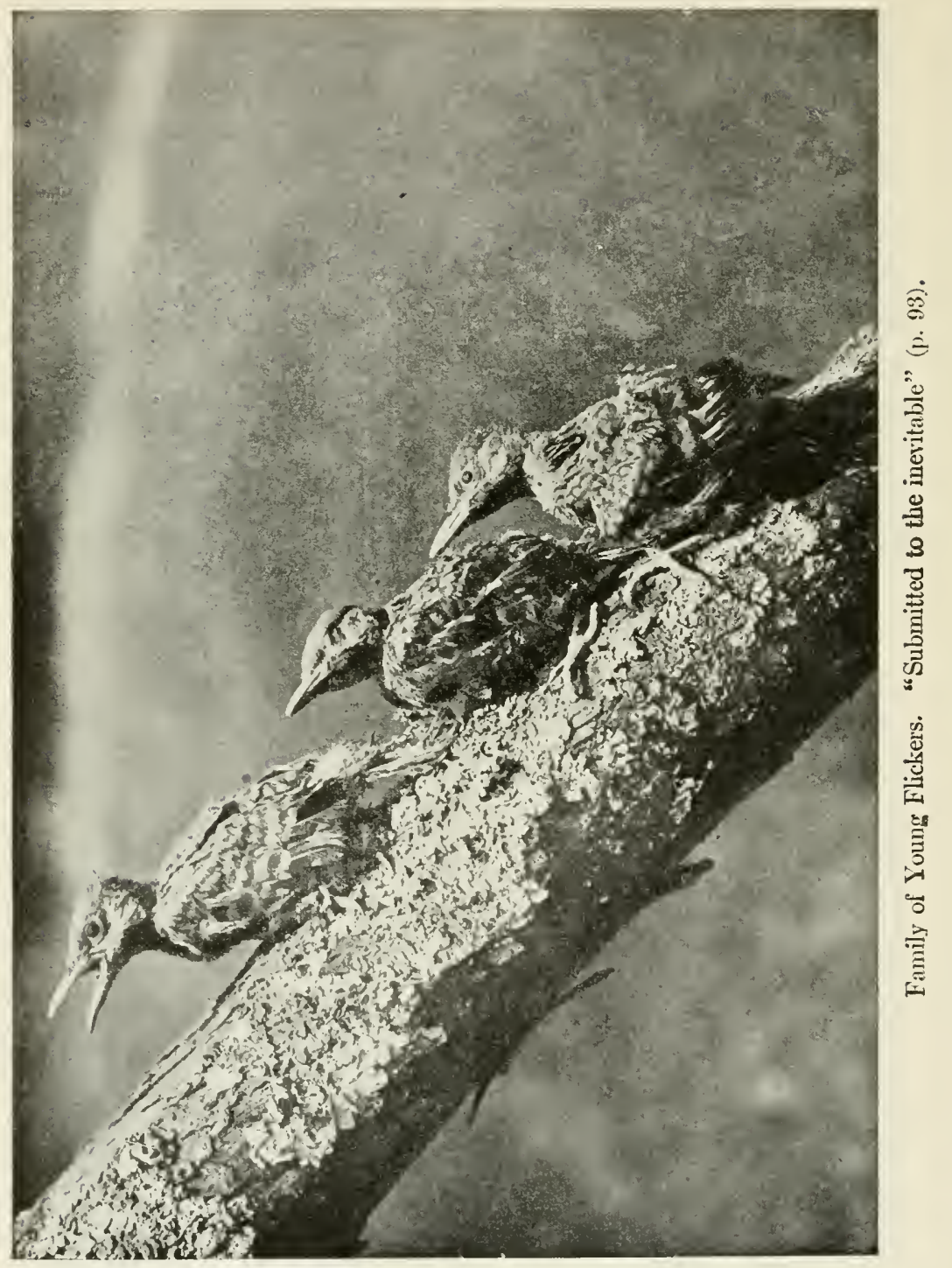




\section{KNIGHTS OF THE CHISEL}

bird. After stroking her I opened my hand and away she went. Now I could just touch eggs at the bottom, as deep down as I could reach.

The picture of the bird by the hole was not very good, as the side of her toward the camera was shaded, so I tried again, and set a mirror on the grass throwing a strong beam on the hole and below it. Now I was in for all sorts of trouble. The bird was afraid of the mirror and would not brave it for quite a while, though she did in time. Meanwhile the sun changed position and the reflection fell too low. When I went and altered it the bird saw me and stayed away longer. Then, as I waited I noticed that the light was cut off and returned in rather an erratic manner. I was down the slope of the hill and could not see the mirror, so crept up higher to investigate, and was surprised and amused to see a cow standing with her head lowered, gazing threateningly at the imaginary cow before her. I really think that in another moment she would have "tossed" her likeness had I not driven her off. Somehow she had managed to step over the thread without touching it, which was fortunate, as she might have wrecked the shutter before breaking the strong linen thread. She was bound, though, to come back and get satisfaction from the supposed bovine usurper, so I had to keep driving her back. The bird returned several times, though the light was never where I wanted it. I tried short timed exposures, but in each the bird proved to have moved, for the young, now 


\section{KNIGHTS OF THE CHISEL}

hatched, were clamoring for food, making that horrible buzzing noise which sounds like a nest of snakes. Naked and scrawny, they looked as hideous as they sounded. But I secured one instantaneous exposure on the bird in dull light, which, though very thin, printed quite well on contrasty developing paper, and was the best which I secured.

I waited a few days more till I thought the youngsters would have some feathers, and went to photograph them. No buzzing greeted me, and I was shocked. Putting my hand into the hole, I drew out the putrid body of one of the young, without feathers. Apparently the others, unable to endure this horrible condition, had climbed out before their full time, or else they had grown faster than I had supposed possible. But what should I do for photographs of young woodpeckers for my series:- It was now so late in the season that I feared that all young Flickers had left their nests. As soon as I could, I made the round of most of the nests I had previously seen. In every case I was too late. Then I heard of a nest on someone's front lawn, in a maple tree, where very recently the young were looking out and being fed by their parents. That very evening I drove to the place, and to my joy found that the young were there and in just the right condition to photograph.

The next morning, July fifth, I was early at work. The hole was twenty feet up the elm, an enlarged knot hole. The young drew back when I tried to get hold of them. The hole was too small for my hand, and 92 


\section{KNIGHTS OF THE CHISEL}

the wood too hard for my knife, so I borrowed a dull hatchet and finally, standing on the spikes of my climbing irons, with great difficulty managed to enlarge the entrance enough to reach in. There were three young, which I put in my creel, and a dead one full of maggots. What a horrible time young woodpeckers must have in these pestilential holes! I noticed, though, that they kept up from the bottom, and clung to the sides near the entrance, thus being able to stand it-in more senses than one.

At first when I tried to pose them before the camera -clinging to a tree trunk, on a post, or ranged along a branch-they were very unruly. But in time, like most young birds, they finally wearied of trying to escape and submitted to the inevitable. One was particularly lively and troublesome, doubtless the one which got the most food. The people of the house had been watching the feeding process, and had noticed that one youngster seemed to cling by the entrance for hours at a time and block the others, getting most of the feeding from the stupid or partial parents. Having photographed them, I put them back in the hole, after cleaning it out and partly filling it with grass. The old birds had been quite concerned and soon one of them came sliding down the trunk, making a rather pretty plaintive whining call which set the youngsters almost frantic, for they well knew what it meant. She was a little shy of the group watching her, but she soon went and fed the first one that stuck out his head. It 


\section{KNIGHTS OF THE CHISEL}

was the smallest of them which I had stationed at the entrance that he might get the start of his tyrannical stronger brother.

Ned was too deep in Fourth of July and its aftermath to come with me. He wanted to photograph them, though, so next day we made another visit, but the tender-hearted mistress of the place was so fearful that the old birds would get frightened off by too much photographing that we gave it up, and drove on to more exciting adventures, which shall later be described.

As our minds were on woodpeckers, it was but natural that we should talk about them. Ned asked me to tell him about some of the kinds which he had never seen alive, and I was willing enough, for it is always pleasant to share with others the enjoyment we have had with the birds. Besides the Flicker, the only others which were familiar to Ned were the Downy and Hairy Woodpeckers, both of which, especially the former, are common with us all the year around. Besides these he has seen the beautiful one with variegated plumage, the Yellow-bellied Sapsucker, which we have only as a spring and fall migrant and never seems very common, though they say that plenty of them nest in the forests of northern New England. This is the kind which bores so many small round holes in apple trees, sometimes for finding grubs, but also to drink the sap.

'Then there is the Red-headed Woodpecker, red, white and blue, a gaudy bird, with its flaming brilliant 
red head and neck. This spring about the middle of May, a pair of them put in their appearance at a farm some two miles from where I live. They seemed to like it and stayed about the row of fine old sugar maples and other shade trees along the street. Ned and I did hope that they would remain for the summer, but in a few days they grew restless and moved on. Years and years ago they used to be quite plenty in New England, but now they are rare and we must go further south and west to find them. When I was a boy, a flock of them came to the suburbs of Boston and stayed all the fall, and a few well into the winter. I could . almost always find them in a certain grove of nice large oaks, and I improved this only opportunity I ever had to know them till I extended my bird searchings to other sections.

There is another of this gentry of the chisel which has mostly disappeared from the midclle districts where it was once well known, the great black and white Pileated Woodpecker, which is as big as a crow. It is common yet in the north roods, and, curiously, in the extreme south. I have met it in Florida, and it seemed strange enough to see these great climbers, which seemed too large to be woodpeckers. They make a prodigious noise with their hammering, and tear off great strips of bark from decaying trees. They are only rarely seen in southern New England. I know two reliable people who have seen them in western Connecticut quite recently; one instance was of a 


\section{KNIGHTS OF THE CHISEL}

specimen in winter, and the other of a pair actually breeding.

There is always a bare possibility in winter of running across one of the rare northern woodpeckers characterized by having but three toes on each foot. Of these there are two kinds, the Arctic Three-toed and the American Three-toed Woodpeckers. Though I never have had the luck to meet one alive, I look carefully at every woodpecker I see in winter, hoping that it may prove to be one of these. A very few have been recorded south of the northern tier of States, and some fine day Ned or I may be among the fortunate discoverers.

We began this chapter witl a common woodpecker, so we will end it by telling of two familiar birds which are so much alike that many people see no difference between them-the Hairy and the Downy Woodpeckers. These are the black and white spotted ones, so often seen about our homes, especially in the winter, when hunger and cold drive them to us for succor. They are almost exactly alike in plumage, but the Hairy Woodpecker is much the larger, having about double the weight of the little Downy. But why this one should have been called "Hairy" instead of the other is too much of a sticker for me. Both kinds have hairy bristles protecting the base of the bill. The larger one may have been named first, and so the little fellow had to take any old name they could fix up. Surely it is no more downy in plumage than any other small bird. But this is just as reasonable as many other names-of 


\section{KNIGHTS OF THE CHISEL}

birds or of people. The male of each of these wears a distinguishing patch of red on the back of his head, while the females are plain black and white.

"Iairy" is the more northerly in range of the two, and its nest is not so often found as the Downy's. Both of them generally nest in the woods or swamps, but Downy often does so in an orchard or in shade trees near the house. The first nest of the Hairy which I ever found was in the woods near a Barred Owl's nest. I was making an afternoon call on Mrs. Owl, when I heard a woodpecker hammering away very steadily. Following the sound, I found a female Hairy Woodpecker excavating her hole about fifteen feet up in the trunk of a perfectly sound young oak. This bird is very hardy and is among the first of the birds to set up housekeeping in the spring, along with the Bluebird and Robin. This was the middle of April, and on the twenty-ninth I found her incubating four eggs in her completed mansion. The wood was as hard as flint, and it seems wonderful that any bird by "butting" its head against material that turns the edge of a knife blade should be able to dig out a burrow a foot and a half deep.

In the overflowed tract of woodland to which I have already alluded, where Flickers breed so abundantly, every year the Hairy and Downy are also to be foundif one is willing to put on long rubber boots and wade about among the slippery and slimy submerged branches tumbling now and then into a hole. Almost always I 


\section{KNIGHTS OF THE CHISEL}

get in orer my boot tops when I try it. My wife thinks it is an abominable place, but Ned and I call it one of the best in town, and that is saying a good deal. Both of these woodpeckers drill their holes in the dead stubs, pretty well up, especially Hairy, who has young well grown by the time Downy has eggs. Both kinds make a great fuss when we intrude upon their eggs, especially if they have young. Indeed, the Hairies are so inclined to borrow trouble that they begin to scold and chatter as soon as they see us coming, and give away the very secret which they are so anxious to conceal.

When the cold winds blow from the icy north and the ground is white with its winter carpet, everyone ought to feed the birds. It is delightful to see how general this custom has become. Hang up a piece of fat meat on a tree near your window, out of reach of cats and dogs, or even on the window sill, and you will be delighted to watch the bird visitors, with their animated ways and eagerly sparkling eyes. Among them will almost surely be our friend "Downy," and sometimes "Hairy," too. They are such nervous, restless, ceaselessly active little bodies, the very embodiment of perpetual motion-especially Hairy. Ies, I see that I can get along nicely by describing Downy, and adding that Hairy is even more so. Really it seems as though two Downies had been concentrated in making one Hairy. It is always especially Hairy! Hairy's nervous "specialty," though, makes him the shier of the two, as might be expected. 


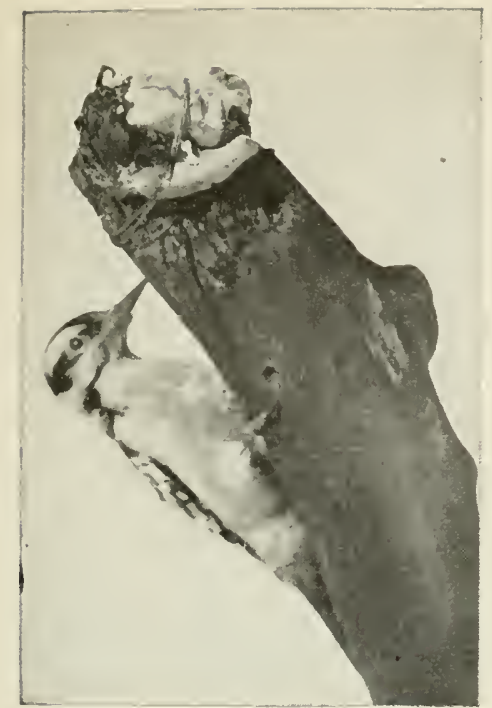

Ned got the Hairy Woodpecker (p. 100).

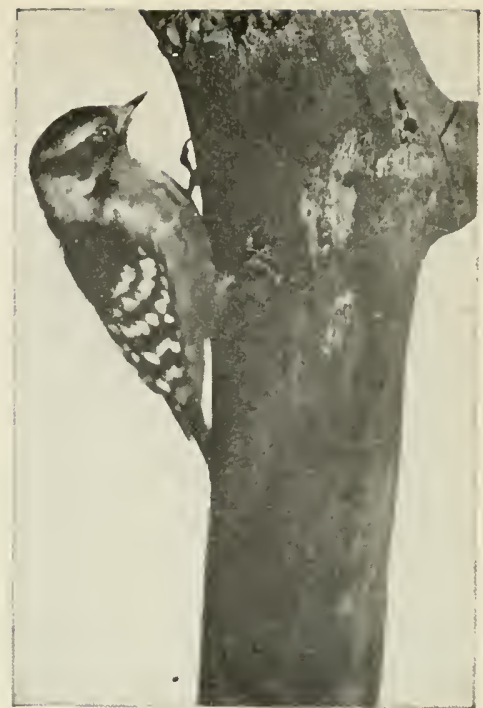

Downy Woodpecker attracted by suet. "Every one ought to feed the birds" (p. 98).

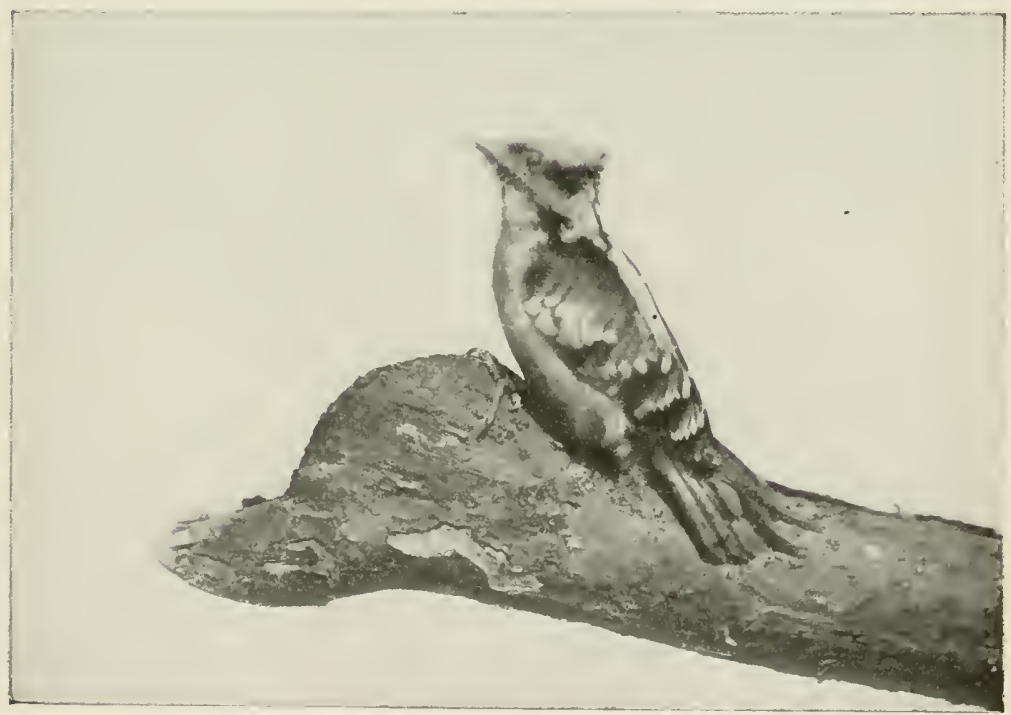

Downy Woodpecker. Angry at a cat, raising its crest (p. 99). 


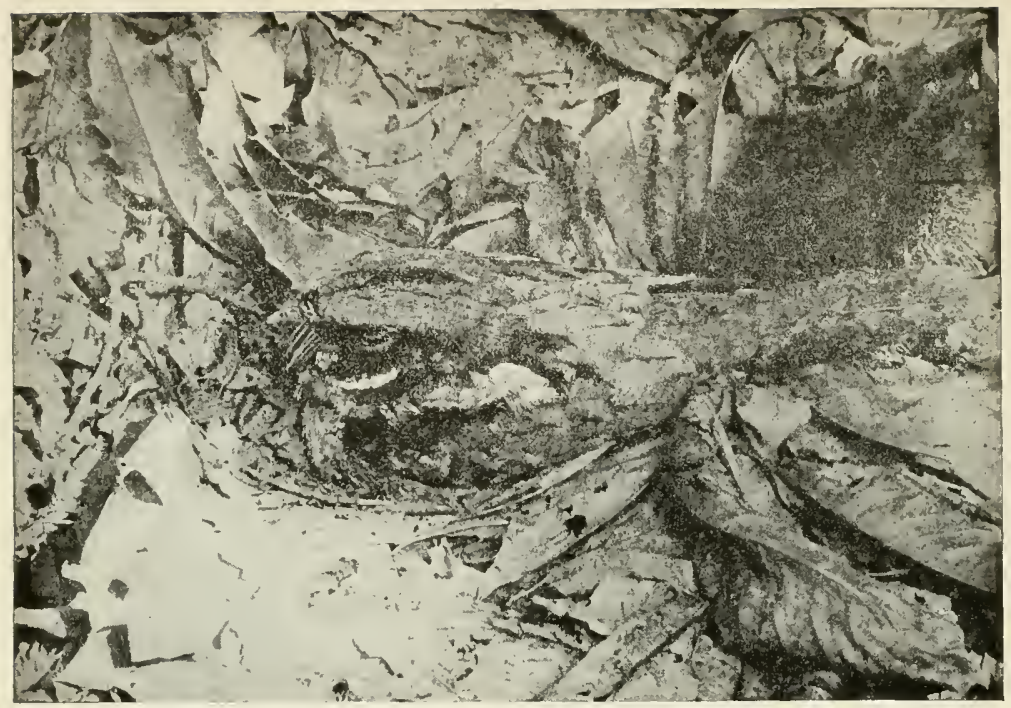

Whippoorwill on nest. "Within two or three feet" (p. 107).

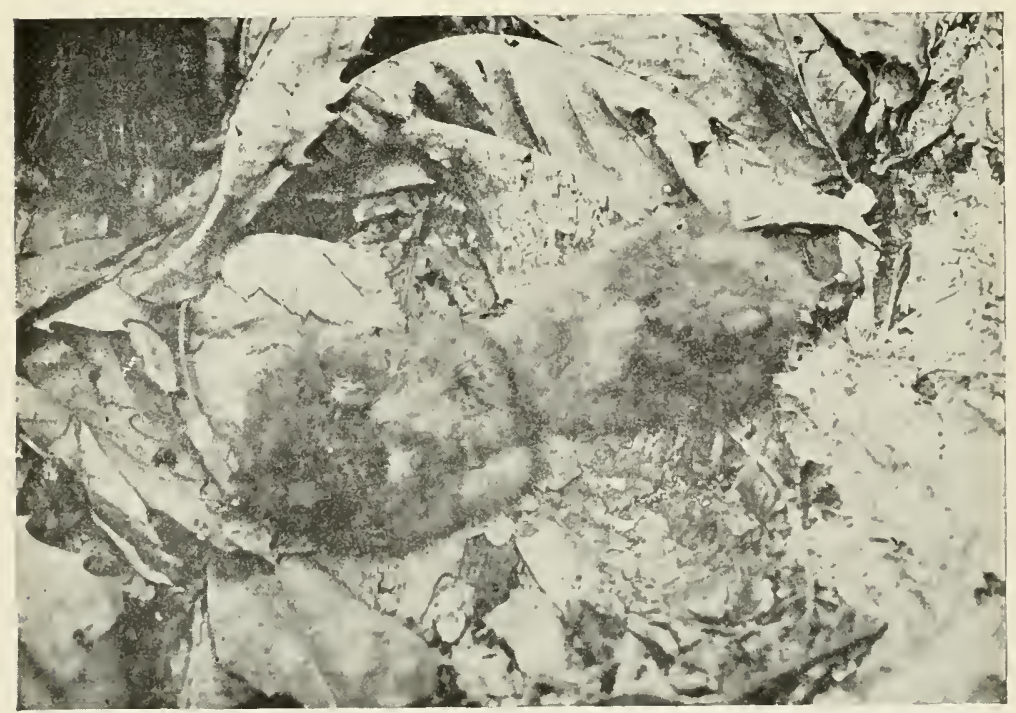

Young Whippoorwills in nest, heads apart. "Two queer little chicks" (p. 108). 


\section{INIGHTS OF THE CHISEL}

This lunch counter arrangement offers a fine chance to secure photographs of our visitors. The camera does not alarm them much, except Hairy!- so we may set it up on the tripod, focus on the food, and, with all in readiness for an instantaneous exposure, lay the line of thread in through the keyhole or under the window, and watch for a good shot. When the bird is just right, pull the thread. This seems easy, and yet it is surprising how many plates one will spoil. The bird is so seldom still that it is very apt indeed to move just as the shutter opens and give a blurred image. The only way is to keep trying, and some of the pictures will be good. Of course one should do this only on a bright day, and use the fastest kind of plate, with lens wide open and the quickest possible exposure.

One day I got a particularly interesting picture of a Downy Woodpecker. A female bird was feeding on some suet nailed under a stub. The camera was all ready, and I was about to pull the thread when I noticed a cat sneaking along the path, hoping to spring on the bird. No sooner did Downy espy the great enemy than she set up an excited and angry chirping, and at the same time erected the feathers on the back of her head and neck to a sharp pointed crest. I pulled, and had her in all her glory. Few people, probably, realize that Woodpeckers can become crested, even the kinds which, unlike the Pileated, have no topknot.

There was little trouble, comparatively, in photographing Downy, but Hairy was quite another proposi- 


\section{KNIGHTS OF THE CHISEL}

tion. A fine male of his persuasion was visiting me daily, but he was so shy and nervous. Before coming to eat he would jerk and dodge, back and forth, till it seemed that he would never come to eat after all. However, in time he would make up his mind, and dart down to the piazza to strike the suet telling knockout blows; with an excited chirp now and then, he would quickly chisel off all he wanted and dart away.

I wasted so much time trying to pull the thread on him and get even a single picture for this book, that Ned thought that he would try to beat me. So he propped up a stick out in the snow with a piece of suet on top, fccused the camera on it, and sat for hours at a window, reading and watching, ready to pull the thread. Now and then the bird appeared, but went off, afraid of the camera. At last, just for an instant, he alighted on the stick, under the meat, and Ned "got" him, as nice as you please. I fear that it will be a long time before Ned stops crowing about how he beat me photographing Hairy Woodpeckers. 


\section{CHAPTER VII}

\section{BIRDS WITH A HANDICAP}

\section{(Goatsucliers and Hummers)}

1

ED thinks he is going to stick me this morning. He wants to know why the order of birds which includes the goatsuckers, hummers and swifts is called "Macrochires," which the book says means long-handed, that is, long-winged, and the gulls are called "Longipennes," which means long-winged, too. I told him the last was derived from the Latin and the other from the Greek language. But this did not satisfy him. He thinks the gulls are well named, but not the others, because among the land birds the swallows are long-winged, too, and the birds of prey, and that "small-footed" would have been a better name, because all these species have small, weak legs and feet. The goatsuckers perch along a branch because their feet are too weak to clasp it easily, and the swifts can only cling, while the hummers, though they can perch, have frail enough little "hands." I had to admit that there was a good deal of reason in what he said and told him I hoped that some day, when he had become a great scientist, he would have some things changed. Meanwhile, now, since we are getting up a book of our 


\section{BIRDS WITH A HANDICAP}

own, we are going to call things whatever we like, so we shall speak of this order as the "handicapped" birds, because their weak hands seem so unfitted for the world's work. Were it not for their strong wings, the handicap would be too much for them.

For convenience sake only, I shall speak of the swifts in the chapter with the swallows, and go on now to these most singular of our birds, the Whippoorwill and the Nighthawk. The ancients called birds of this order "goatsuckers," from the absurd superstition that they sucked the milk from goats with their large mouths, as vampire bats have been said to do. Slander is hard to down, and the bad name has stuck to them ever since.

"Are the Whippoorwill and Nighthawk the same birds?" This is a question which people ask me orer and over again. Well, I should say not! They resemble each other in form and size, and are closely related species, belonging to the same family group, but their habits are very different. The difference is about like that betreen the Song and Chipping Sparrows, the Wood Thrush and the Veery among thrushes, or the Oren-bird and the Redstart among warblers. The Whippoorwill is probably partly to blame for this confusion, for it will seldom give people a good look at it, coming out of its retreat in the woods only after dusk. It looks like the Nighthawk in form, as it flies, so people imagine that the familiar "whip-poor-will" is the Nighthawk's evening song and use both names as for the same bird. 


\section{BIRDS WITH A HANDICAP}

Some of Ned's boy friends have tried very hard to "get" the Whippoorwill, that is, to get a good look at it. When it begins its song in the evening, they follow the sound and try to creep up close to the bird. But it is so dark that the sly rascal usually flits away some distance and begins again its tantalizing call. One boy had the good luck one night to trace the bird to a rock in an open field near the edge of the woods. It was moonlight, and he stole up near enough to see it very plainly. Ned once got a pretty good view of a Whippoorwill on the top of a rail fence, and another night he and I watched for quite a while as it perched lengthwise on the ridge pole of a low roof. What a racket it was making! The people in the house came out to see what was up.

But see now what great differences there are between the Whippoorwill and the Nighthawk. The Whippoorwill is brown, the Nighthawk gray, with a white bar on its wings. 'The Nighthawk is the long-winged bird seen flying about well up in the air in the daytime, especially during the afternoon, uttering a peculiar squeak, and then diving swiftly almost to the earth, making a loud booming sound as it suddenly checks its flight and saves itself from having its brains dashed out. The Whippoorwill, on the other hand, only flies about at dusk and after, not rising high up, but gliding from perch to perch in short sallies, and then, as it perches, it utters the well-known cry which is interpreted-“whip-poor-will, whip-poor-will." The Whip- 


\section{BIRDS WITH A HANDICAP}

poorwill stays during the day in the woods and lays two white eggs sparsely marked with faint lilac on the dead leaves on the ground among the woodland shades; the Nighthawk, when not fiying about, suns itself during the day upon a rock or dusty place out in a field or pasture, and lays its two darkly-marked eggs on or beside a low flat rock which just crops out from the ground in an open lot. In cities people sometimes find Nighthawks' eggs on the flat tar and gravel roofs of blocks of houses.

The entire food of both these birds consists of insects, and they are exceedingly useful. In the south the Nighthawk is popularly knomn as "Bull-bat," and is often called familiarly simply "Bat." It is most unfortunate that there, in some quarters, the custom has arisen of shooting Nightharks as game. They eat enormous quantities of mosquitoes, gnats and flies, also potato bugs, ants, and a variety of noxious insects, and the same is true of the Whippoorwill. Everything possible ought to be done to protect these birds. Possibly the name Nighthawk is responsible for the shooting of this species by ignorant persons who imagine that, as they are "hawks," they must kill chickens. But the poor bird is no hawk at all, rather more like a large swallow, and it is decidedly a day bird, so it badly needs a new name.

The most likely way of obtaining photographs of birds of this class is by first finding their nests. If we should happen upon them in their ordinary haunts 


\section{BIRDS WITH A HANDICAP}

while at rest in the hot part of the day, we might be allowed to steal up fairly near and be allowed time for a snapshot. But such good fortune is rare and at best we should not be able to approach very near. But when the nest is found, particularly when incubation is well under way, the sitting bird is often very tame and the careful worker can be reasonably sure of success.

To speak first of the IVhippoorwill, the eggs are usually laid, in northern or middle districts, about the last of May or the first week in June. The best place to look is in second growth woods, where there is a moderate amount of undergrowth, usually near an opening, and particularly where there is a pile of dry brush or a fallen tree. The bird makes no nest, but merely selects a spot on the dead leaves on the ground, in the shade, where her two handsome eggs are deposited. The way I find a nest is to notice in the evenings where Whippoorwills first begin to call in the woods, and then by day tramp back and forth, round and round, in that territory, beating the bushes with a stick. The brown mother sits very closely, and her colors and markings blend so wonderfully with the surroundings that there is not one chance in a thousand of seeing her thus. However, if we walk within a few feet of her she will fly up and away, and then the white eggs are conspicuous enough.

A few years ago there was a patch of woods and shrubbery, a sort of island surrounded by open fields, in which a pair of Whippoorwills nested each season. 105 


\section{BIRDS WITH A HANDICAP}

I first discovered the nest by accident. TValking through the woods I passed near a pile of brush, when up flew a long-winged brown bird from a shaded spot beside a clump of small saplings and flitted off with silent flight like a bat. There were her two eggs-on the seventh of June-the first Whippoorwill's eggs I had ever found. I secured a fine picture of her by placing the camera close to the nest, covered with leaves, and then, with a thread attached, withdrawing for an hour to let the bird come back, when I pulled the thread for an exposure of one second. The male bird, I found, was accustomed to roost lengthwise along the trunk of a fallen sapling, where I could almost always find him in daytime, but he would not let me come very near. Each year after that, at about the same time, I would visit these woods and flush the female from her eggs, not in the same spot, but within a hundred yards of it. The male always found his old log again, until one day I failed to start him, and scattered brown feathers showed that some hawk or prowling "varmint" had probably made a meal of him. Next winter the grove was cut off and no more Whippoorwills came there.

In the cold, backward spring of $190 \%$, on the twentysixth of June, I was walking with a friend in a grove near his home, when I heard a Scarlet Tanager chirping excitedly, and also a Vireo. We altered our course and went to see what was the matter. The disturber proved to be a marauding jay skulking in the foliage, and the 


\section{BIRDS WITH A HANDICAP}

smaller birds were trying to drive it off. As we stood in a little open place in the woods, it chanced that I was within three feet of a Whippoorwill on its nest. I should never in the world have seen it even then, had not the bird become uneasy over our talking and flushed. There were the two eggs, unusually elongated and very beautifully inarked, evidently freshly laid.

A heavy rain storm was just beginning, so I had to postpone my photographing, and was not able to return till the next week. The bird was on the nest, but so still and inconspicuous that for the life of me I could not see where she was, until in my blundering I started her off. As on the previous occasion, I set the camera on a pile of dead leaves, on a very short tripod. It was a couple of hours beiore she was back on the nest, and then I pulled the thread, first to open the shutter, and ten seconds later to close it. I could see that she remained motionless. Then I crept up silently on hands and knees to change the plate behind the camera, thinking that possibly she might not start. She was now tamer than I had dared to hope. Not only did she let me change the plate and take her again, but she allowed me to move the camera nearer, within two or three feet, and take long-timed exposures for fine detail, with the lens stopped down to a very small opening. The resulting pictures were all that I could possibly desire. I visited her again from time to time with Ned. He took some fine pictures all by himself, as good as mine, and I got a few more. Now we could walk 


\section{BIRDS WITH A HANDICAP}

right up boldly and plant the camera within two feet of her without alarming her. Once I was there after sundown. Having taken a picture in the soft light, I thought I would see if she would let me touch her, but she gave a little hop and flutter and perched upon a fallen branch close by the nest. There she sat motionless, not along the limb, as ordinarily, but almost, if not quite, directly across it. Carefully I turned the camera toward her, after hurriedly screwing on my lens of longest focus, and moving the tripod slowly a little nearer. It was so dark that I could hardly see to focus, and it required quite a long exposure. I made two, the longest and best-as it proved-taking two whole minutes, yet the bird never winked or moved, giving me a fine picture of an unusual sort.

In the morning of the thirteenth of July, seventeen days after I first found the nest, my friend saw a Whippoorwill's eggshell lying in the road, two gunshots from the nest, so he surmised that the eggs I was watching had just hatched. 'Two days later I found the mother brooding two queer little chicks covered with yellowish down, right in the holiow where the eggs had been. She was reluctant to leave them, and when she did they scurried away a foot or two, and squatted in the leaves. I photographed them at once, for I knew that they were liable any day to scramble off, as one spot to them is as good as another. It was well that I did so, for when I came again, the next week, they had disappeared. Sometimes, it is said, the mother removes 108 


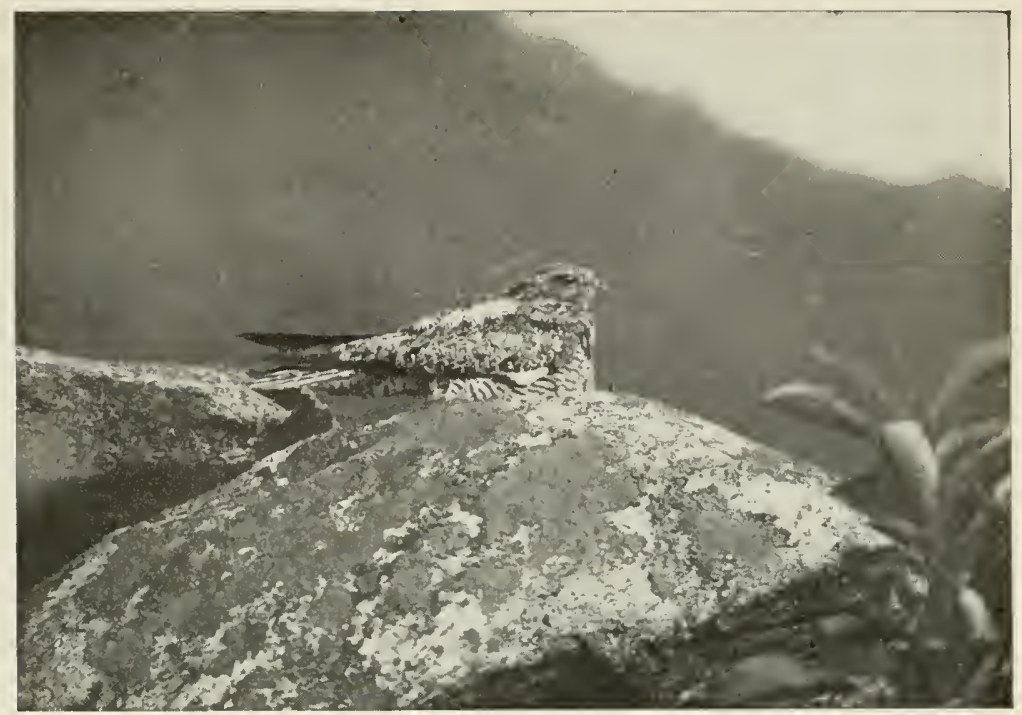

Nighthawk. "Blends with the gray of the - . rock" (p. 109).

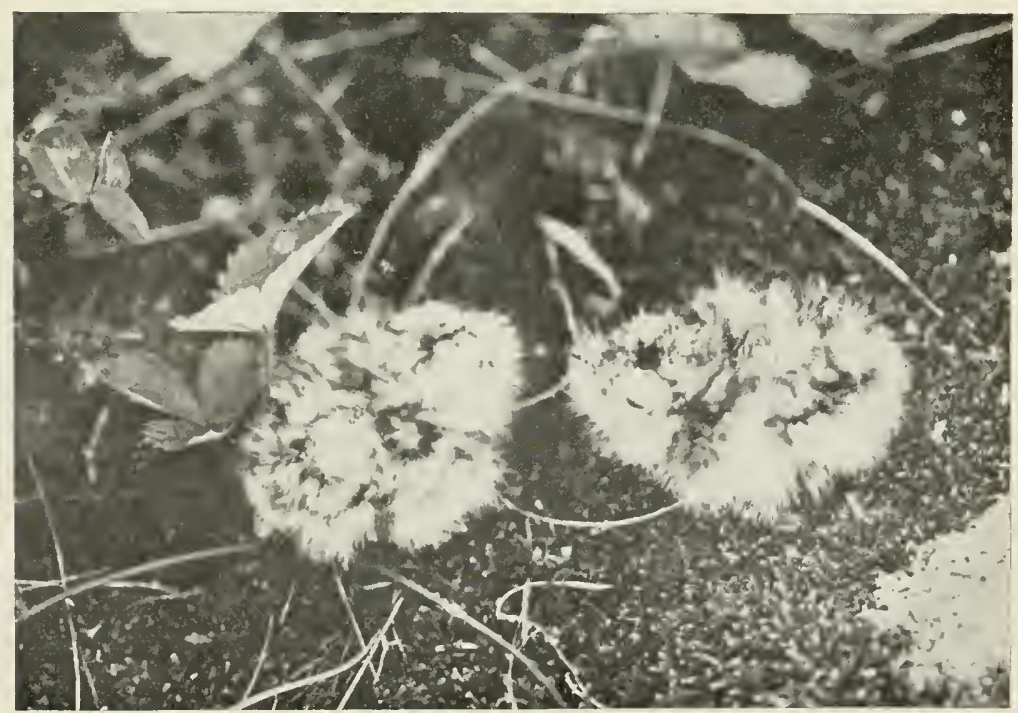

Young Nighthawks. "Singular little striped fellows" (p. 110). 


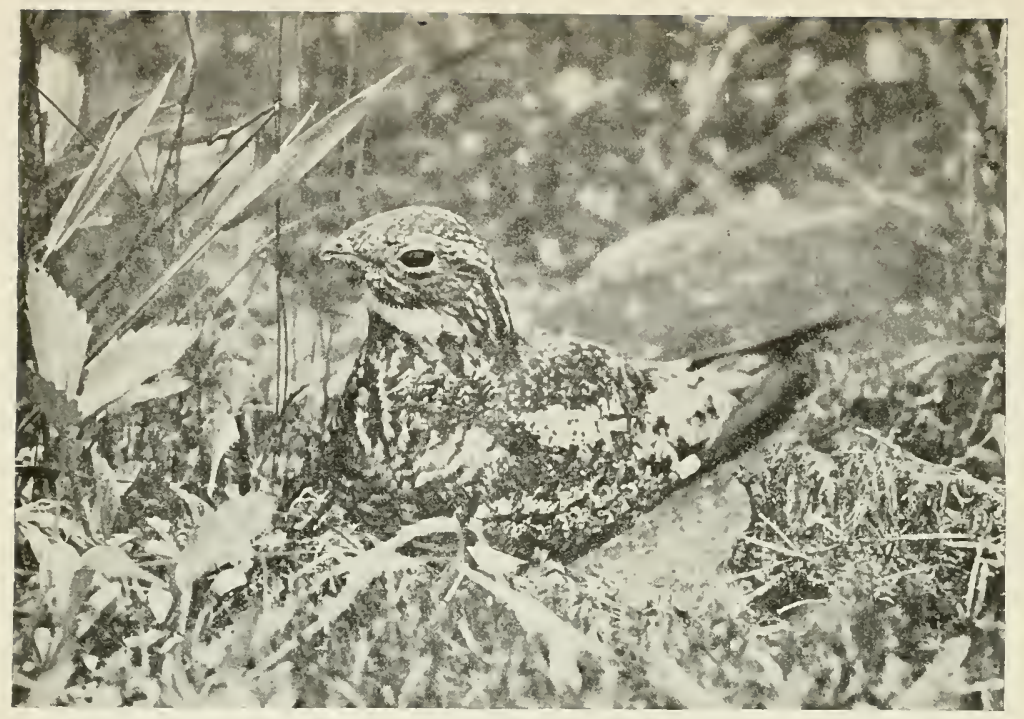

Nighthawk on egrgs, alarmed. "My preferred stalking-horse for photographs" (p. 110).

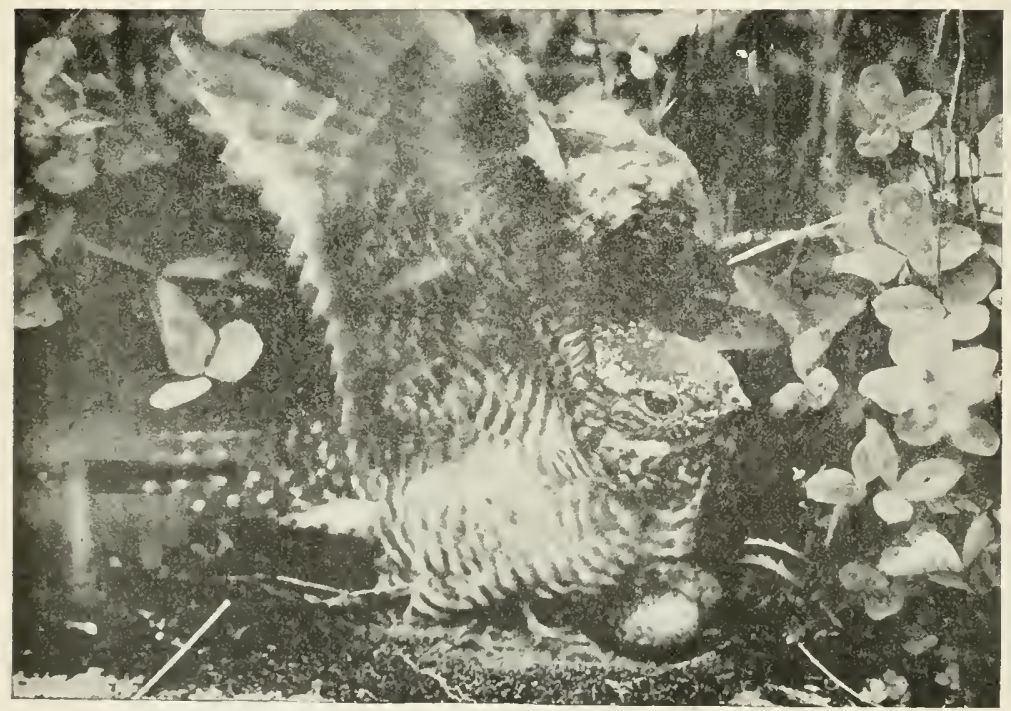

Nighthawk by her eggs. "Made her raise her wings" (p. 110). 


\section{BIRDS WITH A HANDICAP}

the young, or even the eggs, in her mouth to a place of safety when they have been intruded upon.

The Nighthawk, like the Whippoorwill, is very tenacious of its nesting location. Year after year the pair will resort to the same identical low flat rock in the old pasture or hay field, or to another close by. The eggs are laid at about the same time as the IVhippoorwills'. It is often fearfully hot on the unshielded rock, out in the glare of the summer sun, but the bird sticks bravely to her task and seems to know no such thing as sunstroke.

Just as the Whippoorwil! blends with the brown of the dead leaves, so does the Nighthawk with the gray of the weather-beaten rock. Not long ago I conducted a party of ladies, members of a bird club, to inspect a Nighthawk on her nest. There were ten of them, and in extended line we approached the spot, a low flat rock just projecting from the ground, in a hay field. When we were perhaps twenty feet away, we stopped, and I pointed to the motionless bird. Ten pairs of field glasses were leveled at the poor, modest creature. This aggregation must have looked about as formidable to her as a company of soldiers aiming their rifles would have done to us. She was relying, though, on her protective coloration, and, indeed, not one of the enthusiasts was able at first to make her out. At last, one by one, each with a squeal of delight, made the great discovery. They fairly stared her out of countenance, for, as we drew a little nearer, she fluttered off, dragging her wings 


\section{BIRDS WITH A HANDICAP}

over the grass as though badly wounded, to tempt us to follow her.

Though I knew of various Nighthawk locations, and found their eggs from year to year, this bird was especially tame, and was my preferred stalking-horse for photographs. I first snapped her in 1900, using a thread, from a distance. Every season she set up business at the old stand, and in 1907 I found her-late, like the Whippoorwill-on the first day of July with two fresh eggs. By creeping up very carefully and making every movement slowly, I was able to place the camera, on the tripod, within less than a yard of her, and took as many pictures as I needed, without having to retire and wait. Ned tried to "get" her that day with the camera, but he was in too much of a hurry and scared her off; but later he snapped her with the "Reflex," as she sat on a rock.

On July sixteenth the eggs were evidently about to hatch, and the Nighthawk was tamer than I had ever known one to become. Not only could I photograph her, but I poked her with a short stick and made her stand up and raise her wings beside the eggs without flying. On the nineteenth I found the young hatched, the eggshells still lying near by on the rock. It was well that I photographed the singular little striped fellows when I did, for next day the field was morved. The men put the little birds on a higher rock so that they might not be injured, but a few days later, when I came, they had disappeared. Either the old birds moved 110 


\section{BIRDS WITH A HANDICAP}

them, or else some prowling varmint got them, which last we trust did not occur.

It seemed but a few days till the last of August, when the Nighthawks began to appear in straggling flocks, flying southward in a leisurely manner, catching insects as they went. On the eighth of September the sky for hours was dotted with them in every direction. It was reassuring to any bird lover to see so many, proving that there must yet be some places where they are abundant. But there came with it also a minor cadence, a thought as of sere and yellow autumn. "Ned," I said to him, "those migrants are telling us that we shall photograph no more nesting Nighthawks this year."

Though the art museums of Europe may have some treasures of which America cannot boast, our continent has the distinction of a monopoly of the world's supply of Hummingbirds, the gems of all the feathered creation. Of these there are said to be some four hundred species-the four hundred we may call them!-nearly all of which are peculiar to the tropical regions. Only eighteen cross the borders of the United States from Mexico, and appear only in our southwestern States, except one, our familiar little "Ruby-throat," which is found throughout the United States and up as far north as Labrador. Nothing in bird life is comparable with these wonderful tiny creatures. They are literally gems, in that their feathers flash brilliant, wonderful hues which vary as in the kaleidoscope at every angle of 


\section{BIRDS WITH A HANDICAP}

vision. Their motions are too rapid for the eye clearly to follow. Though they have no song, and emit only an insect-like chirp or squeak, the hummer, as a writer has prettily said, "needs none. Its beauty gives it distinction, and its wings make music."

Nearly everyone knows the little hummer-the Ruby-throated Hummingbird, the books call it-which darts about in the garden from flower to flower. Its tiny wings move so rapidly that they appear only as a blur, and produce the humming sound from which the bird takes its name. Almost fearless of man, it hovers by the blossom close beside us, like some large insect. Though it measures a trifle over three inches long, there are insects which can easily be mistaken for it. A certain large moth has often deceived me for the moment; but the fact that it comes in the dusk, when the little hummer has gone to bed, may guard one against being deceived.

The popular idea is that the hummer lives only on honey gathered from flowers. This is a mistake. The bird does secure some honey, but its food consists mainly of the small insects which frequent the flowers. Some of these insects are injurious to the blossom and the tiny bird fulfills a useful function in destroying them. That the hummer is insectivorous is also shown by its habit of catching tiny insects on the wing, which is occasionally observed.

So familiar are Hummingbirds toward man that they will readily enter open windows of houses if they see 


\section{BIRDS WITH A HANDICAP}

flowers within. I have even read of their visiting the artificial flowers on a lady's hat when she was walking out, and other writers speak of their taking sugar from between a person's lips. In a room they become confused, and, being so frail, are apt to injure themselves by striking against objects. More than once $I$ or members of my family have caught the frightened little waifs for their good, and released them in the open air. It is of no use to try to keep them in captivity, unless, possibly, it were in a greenhouse where there were plenty of flowers, for no artificial food has ever been found which will nourish them. Yet even there they would probably kill themselves by flying against the glass.

We may expect the little hummer in the Middle States or New England early in May each year. They seem to come paired and resort each time to the familiar hunting grounds. At least we are apt to see Hummingbirds in the same places year after year. By early June each pair has its dainty nest and two tiny white eggs hardly larger than peas. A favorite site for the nest is an old lichen-grown apple tree in an orchard, generally not high up. But often they will choose some shade tree, like a maple, in the garden or along the street. Sometimes it is on a tree in a swamp or in deep woods.

It was in the latter situation that I found my first occupied nest of the hummer, though, when a small boy, I remember discovering the home of a pair that frequented our garden, saddled to the lower limb of a 


\section{BIRDS WITH A HANUICAP}

larch tree close by the house, but only after the birds had left it. It was one Memorial Day, and with a friend I was looking for birds in some tall white pine woods. My attention was attracted by a Veery, or Wilson's Thrush, which flew up from the ground into a pine. Just as it alighted it was attacked in the most violent manner by a tiny bird, which was so quick in its motions that I could hardly tell what was going on. The thrush, though a far larger bird, unable to rival such velocity and deftness of attack, was driven off in a hurry. Naturally we assumed that there was a nest near, and sure enough, there it was, about two-thirds way out on one of the lower branches of the pine, some fifteen feet up, not in a crotch, but built on to the branch itself, as though it were a knot or excrescence of the same. While we examined it the female buzzed and darted about our heads like an angry bee. As for the male, he did not put in his appearance, and I have reason to fear that he is a shirk. Since then I have found various nests, but I do not in any case recall seeing the male about when his wife was in distress over the intrusion. Some writers state that he leaves to her all the care of eggs and young. Formerly he was very ardent in his protestations of affection and devotion, but now, as the flowers expand in greater profusion, he finds them more interesting than the prosaic duties of home.

This home, howbeit, is one of the most remarkable and artistic creations of all bird architecture. It is a 


\section{BIRDS WITH A IIANDICAP}

tiny, delicate cup, made of the softest plant down, saddled upon some rather slender branch, so deftly that it seems a part thereof. Delicate cobweb threads are used to compact and secure the material, and likewise to coat the exterior with the gray-green lichens so generally found upon trees. This makes it so assimilate with the surroundings that it is a very difficult object to discover. And thereby hangs a tale. A gentleman had told me that, if I would call upon him, he would show me an occupied nest of a Hummingbird in his orchard. When I came he was out of town, but I thought I would see if I could not find the nest myself. So I made inspection from tree to tree, and presently the female hummer began to fly about me anxiously. We played a game of hot and cold until it became evident that the nest must be in a certain low apple tree which had many dead, lichen-covered branches. Some of these came down nearly to the ground, and for quite a while I stood by the tree, running my eyes along each branch in order, trying to make out the nest, while the female kept darting frantically at my head. It must have been nearly a quarter of an hour before I discovered that I was standing almost touching the nest with my hands, having been looking right over it all the time. It contained two fresh eggs, this being in the early part of June. The branch upon which it was built was completely overgrown with lichens, and the nest, covered with them too, was wonderfully disguised, though there were no leaves to hide it. 


\section{BIRDS WITH A HANDICAP}

Another nest I found in a similar fashion, but much more easily. I was in a patch of swampy thicket of low trees and bushes adjoining a meadow. A hummer began to dart about, so I looked for the nest and almost at once saw it, well out on a low branch of a maple. There were no lichens on this green branch, though they had been plastered on the nest, as usual, so that it was more conspicuous than in the other case. This nest also had two eggs.

These hatch in less than two weeks, probably ten to twelve days, and in two weeks more the young have grown up and gone. There is easily time, then, for a second brood to mature before the nights grow cool, and the hummers often take advantage of this fact. One day in July a little girl came running in to tell us that she had found a hummer's nest in the orchard back of our home. It was placed on a low branch, about breast high from the ground, and contained but one egg. The little mother darted about, alighting here and there on slender twigs as I examined the nest. When I withdrew a few yards she would quickly return to her duty. It was a beautiful sight to see her enter the nest. She did not perch upon the edge, but hovered over it, and, with wings speeding like the wheel of a dynamo, would then drop right into her little cup just as a piece of thistle-down might have settled upon it, lightly and airily, making one of the prettiest bird sights that I have ever seen.

Evidently it was a fine chance to photograph, not 116 


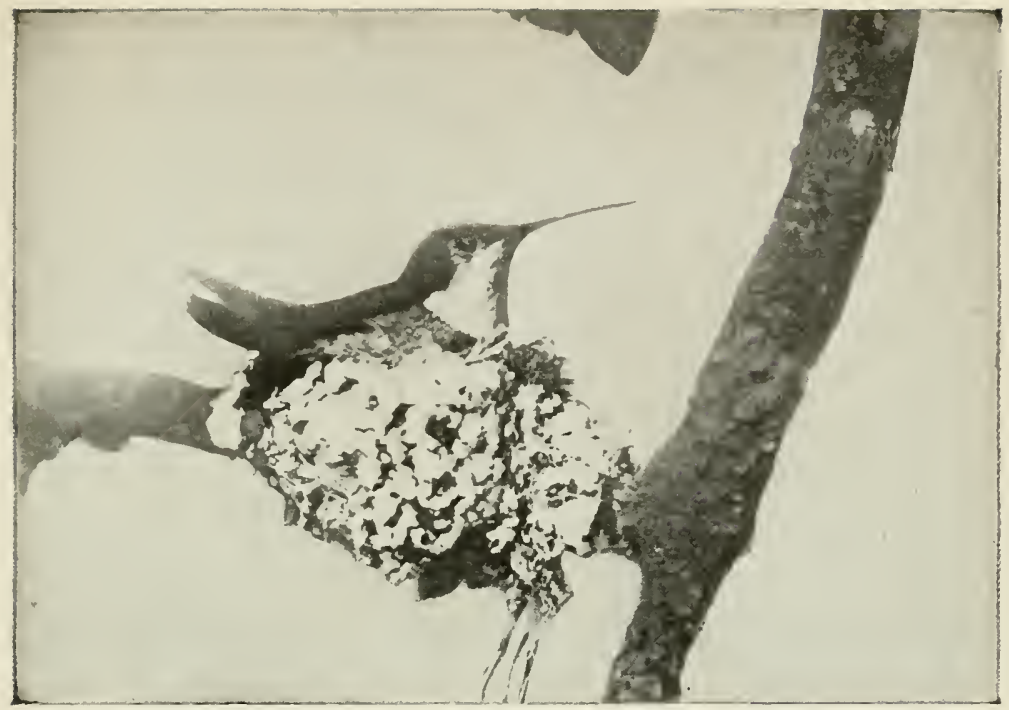

Humming Bird incubating. "Would quickly return to her duty" (p. 116).

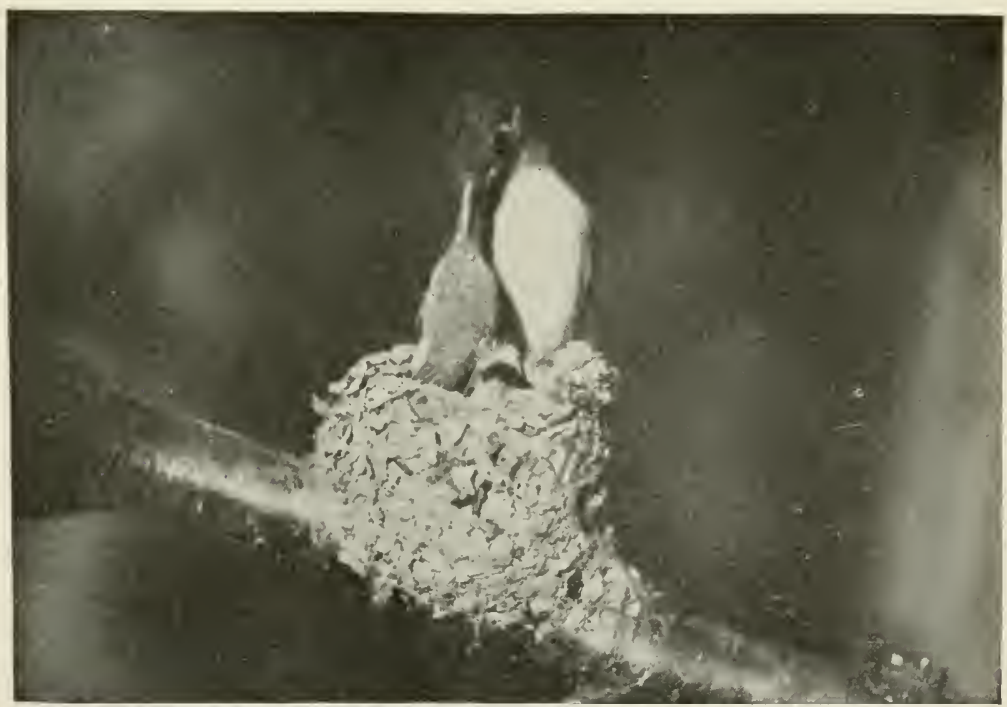

Hummer "in the mids; of the feeding comedy" (p. 120). 


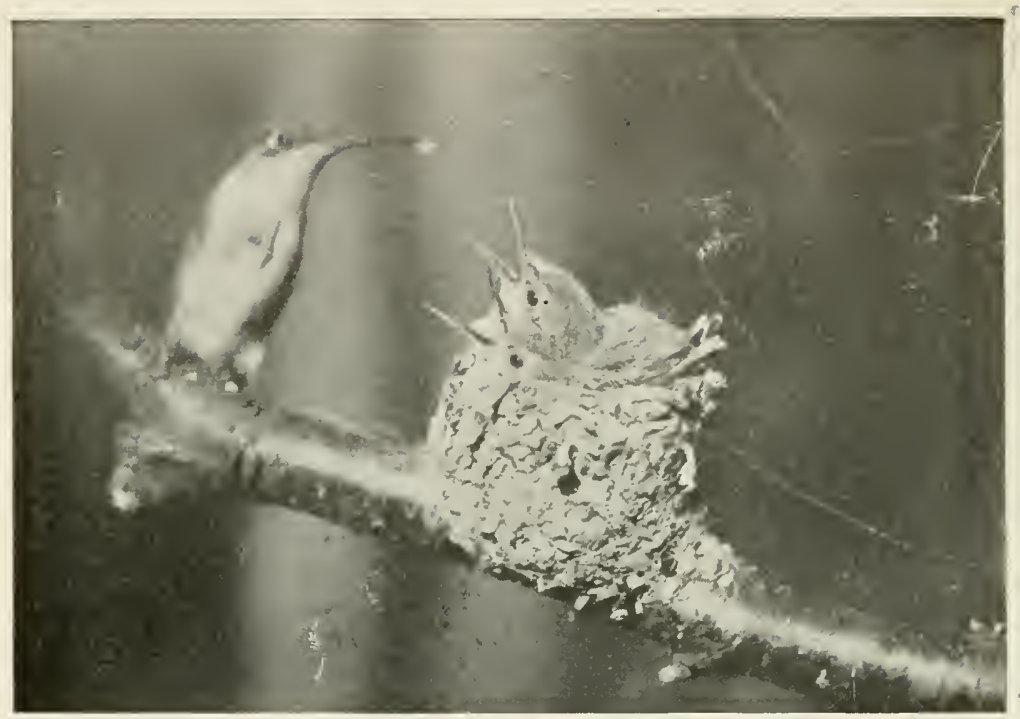

Hummer and young. " Sometimes she would bring a small whitish insect" (p. 120)

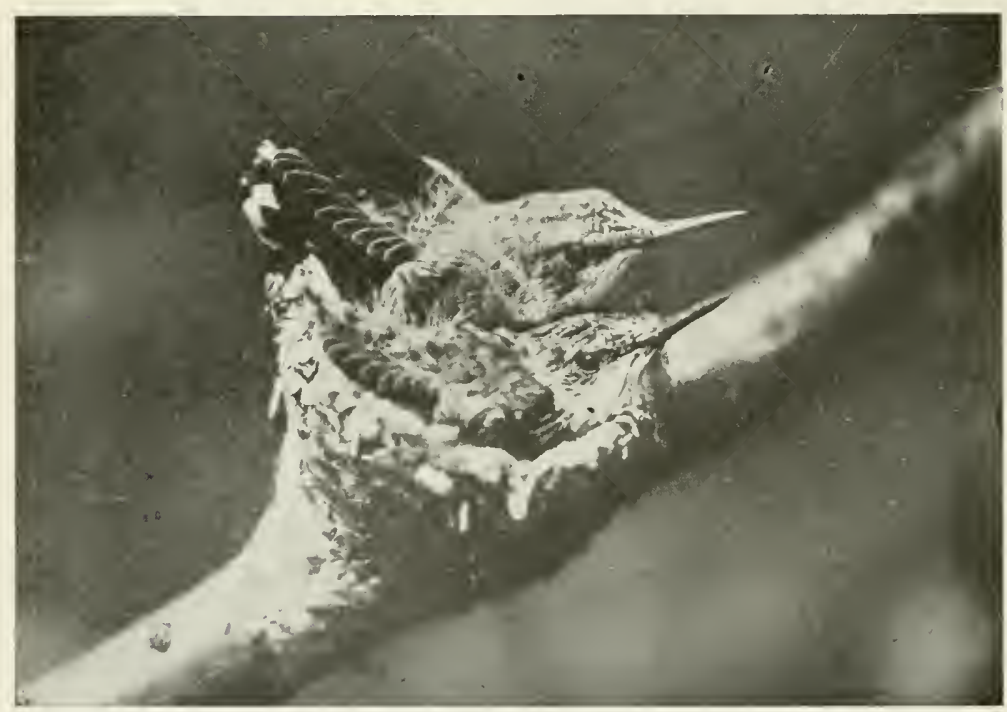

Young Hummers in nest. "A pretty confiding air about the little beauties" (p. 119). 


\section{BIRDS IVITU A HANDICAP}

only the nest, but the bird upon it as well. This was a decade ago, when I was just beginning to photograph wild birds, and I did not utilize the opportunity as fully as I should have done later. However, I set up the camera upon the tripod, very close to the nest, and, attaching the thread to the shutter, sat down under the next tree to await my opportunity. The hummer returned to the nest at once, paying no heed to the instrument. Unfortunately the foliage obscured the light, and at that time I was under the false impression that a slow plate would give the best results, with most detail, in this sort of work. This necessitated a timed exposure, and the bird was almost sure to turn her head when the shutter opened. Thus I accumulated a series of pictures of a double-headed hummer, a species which is not recognized by scientists. One negative, from a snapshot, was sharp but very faint. Yet there is hope even thus of a valuable exposure, if only there be detail, however weak. The best thing to do is to print or enlarge on the most contrasty grade of glossy lamplight paper, which will give a strong, plucky print. If it is too black, reduce it to the proper degree with red prussiate of potassium reducer, as one would a plate, giving local reduction where it is needed. Then photograph the print in a way not to show the grain of the paper, and the resulting negative, as compared with the original, will prove a surprise and a delight. A rare and valuable picture is well worth this trouble, and I have saved many undertimed snapshots in this way. 


\section{BIRDS WITH A HANDICAP}

In this case there was no opportunity for camera studies of the young hummer, for the egg never hatched. The faithful mother brooded it week after week till she lost heart and quit. Then I took possession and b!ew the egg, finding in it nothing but water.

The time came, at length, when I was to have every facility for this study and when, with wider experience, I could take full advantage of it. It came at a season when I had no idea of any more pictures of bird nesting, unless of the ever tardy Goldfinch-in mid-August. A road was being cut through a tract of woods, just back from the shore of a small lake. One afternoon they cut down a black birch tree, and the next morning, when one of the men was cutting it up, he heard a continued chirping, and, upon making investigation, found the nest of a Hummingbird out on a slender branch of the fallen tree, about twenty-five fect up from the base. It was tipped over to one side, yet in it was a young hummer, clinging to the soft lining, and on the ground beneath it was another. They were nearly fledged and just about able to fly. Taking pity on the poor little things, the man cut off the limb with the nest, fixed it firmly between two trees about five feet from the ground, and placed the little hummers upon it. At first they fluttered out, and, indeed, they seemed so much too large for the tiny cup that it appeared almost impossible for them both to fit in. But what man could not do the birds did themselves, when they got good and ready. The men on the estate were much 118 


\section{BIRDS WITH A HANDICAP}

interested in the tiny creatures, and, fearing that they were abandoned to starve, sent to me to learn how to feed them. Fortunately, however, there was no need for clumsy human effort, which would have been unavailing. The mother bird soon found them, as she may have done already, and was busy feeding them long before I arrived, which was not until the next day.

It was a sight which well repaid me for the drive up the steep mountain road. The nest itself was beautiful, but even more so were the tiny mites of bird life which occupied it. The old saying that there is always room for one more may be true in human affairs, but it certainly would not apply to this hummer's nest. Both birds were side by side, facing the same way, tails and bills projecting over the rim of the nest. The green and gray of their plumage harmonized beautifully with the greenish lichens which adorned the nest. There was a pretty, confiding air about the little beauties. They did not seem afraid and I could approach them as closely as I wished without alarming them.

As it was already mid-afternoon, I set about photographing them at once. Presently, as I was arranging the camera, I heard a buzzing sound, and the young began to chirp and struggle excitedly. The mother had come to feed them, but she went off when she sarv me. As soon as I had photographed the young in the nest, I tied a thread to the shutter and sat down a few rods away; hoping for a shot the next time that the mother 


\section{BIRDS WITH A HANDICAP}

came with food. After some little waiting, I again heard the buzzing sound. It was the old bird; yet she did not come directly to the nest, but alighted well up in a tree near by. Then she perched on a twig near the nest, where she stood quivering her wings. The young were greatly excited; they chirped with all their might. quivering with eagerness, and opened their outstretched bills, begging for food. Then the mother hovered close over them, but darted away, not liking the camera. After doing this a few times, she alighted on the branch close to the nest, and I sprung the shutter. Its snap frightened her away, and I changed the plate. She soon returned, and this time I waited till she was in the midst of the feeding comedy before I pulled.

This is a most remarkable performance. The parent alights on the edge of the nest and stands quietly for a moment, while the young are begging with all the eloquence and earnestness which would betoken a matter of life and death-as it certainly is to them, poor little things! Perhaps she is deciding which youngster to favor and making inward preparation for what naturalists call the act of regurgitation. Selecting the fortunate hopeful, she inserts her bill into the widelyopened mouth and forces it deep down into the anatomy of the youngster. Then she rams it violently up and down, and with each jerk ejects from her crop the luscious nectar, a mixture of partly digested insects and honey. Sometimes she would bring a small whitish insect held at the tip of her bill, but when she fed this 


\section{BIRDS WITH A HANDICAP}

to the chick, she also continued the meal with other food from the store below. Meanwhile the other little fellow would appear terribly disappointed. Then the shutter would click and she would dart away, but we may believe that the next time she knew enough to feed the other chick.

I had only one more shot that afternoon, and then the sun sank behind the tops of the forest. In the little clearing the light only served from eleven to four oclock, and the next day I gave this space of time to the work. At first I moved the nest lower down and secured even better pictures of the young than I had done the day before. Just as I had made the last exposure which I desired, the old bird began to buzz around. One of the young became very uneasy. It stirred about in the nest and began to whir its wings. At first this had no effect, but presently the wings took hold upon the air, and the little one floated upward as slowly and gently as a feather and reached a branch a dozen feet from the ground. I tried to catch it and put it back, but only made it fly up higher into the forest, and I saw it no more, though at times I could hear its little insect-like chirp.

The nest was now in shadow, so I moved it a few yards out into open sunlight and set the camera. Presently the mother bird returned, but did not see the nest and went off. Time draggeed by and she did not return. Alarmed and remorseful I put the nest back close to its former location. The sun's rays came to it, 


\section{BIRDS WITH A HANDICAP}

but not the mother. Meanwhile, the poor chick chirped hungrily and made my heart ache for it. Finally, well along in the afternoon, I heard the familiar buzz, and when the mother came and fed the chick gratitude and delight welled up in my soul. The old hummer now returned at frequent intervals and I secured four more pictures.

On this trip I had the pleasure of the genial and lively society of Ned. He was greatly interested in the various sights and proceedings and assisted me in a number of ways. But the long wait for the return of the mother bird proved too slow for his sanguine temperament. The lake shimmered enticingly through the woodland foliage, and there were fish in it too! I saw that Ned was casting wistful glances in that direction and then toward the nest and the expected hummer. He wanted to see the feeding process, but he did want to "go fishin',"-like any other boy. Ned was certainly a remarkably good ornithologist for his years, but we would not give the impression that he was any little old man, or a "dry-as-dust." That was not the case, for he is a real live American boy and reads a publication of that name. I knew just how he felt and told him to go ahead and get a mess for supper. That was the last I saw of him for quite a while. Toward the end of the afternoon he came back with a string of twenty-five and he was in time to see the mother hummer give her youngster some supper.

The following afternoon I drove my wife up to see 122 


\section{BIRDS WITH A HANDICAP}

the wonder, if, indeed, it were not too late. To our joy the tiny bird was still in the nest and its mother was so attentive that within an hour I had seven more pictures to the good. Pictures of the little dear perching on a twig, ready for his exit into the great wide world, crowned the successful labors. Next day the workmen found only the empty nest which had served well its purpose of giving to the world two more art treasures of bird life. 


\section{CHAPTER VIII}

\section{PROFESSIONAL FLY-CATCHING}

\section{(The Flycatchers)}

NE day I had a fine reward for giving a little girl a ride in my buggy. She was trudging to her home over a mile away, so, as I overtook her, I stopped and let her get in. "Have you seen the bird's nest on top of the post?" was about the first thing she said. "No, where is it?" I inquired. "Just on beyond here," she replied, "I'll show you when we come to it." "There she is on the nest!" presently exclaimed the child. Sure enough, there sat a bird flat on top of one of the posts of the wire fence which separated the highway from the railway track. As we came nearer I saw it was a Kingbird. I slowed the horse down to a walk, and watched to see how near the bird would let us come. The country road was very narrow, and when we were opposite the devoted little mother she was just about within arm's reach, yet there she sat. I stopped the horse, and then she flew up on the telegraph wires overhead, where she expressed noisily her disapproval of my loitering on her premises. She did not mind, the little girl said, if people went along past and attended to 


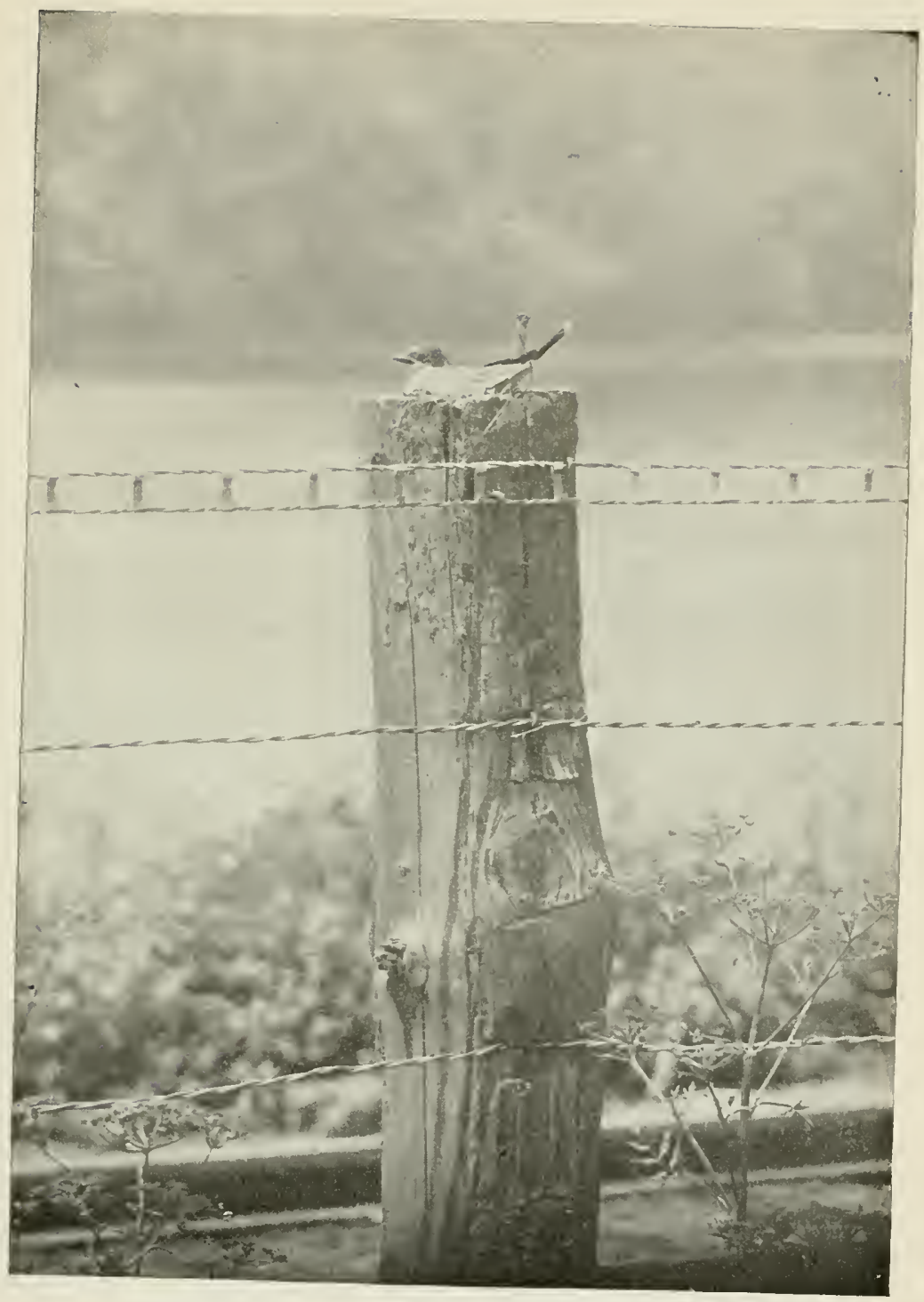

Kingbird on nest. "A most remarkable situation" (p. 125). 


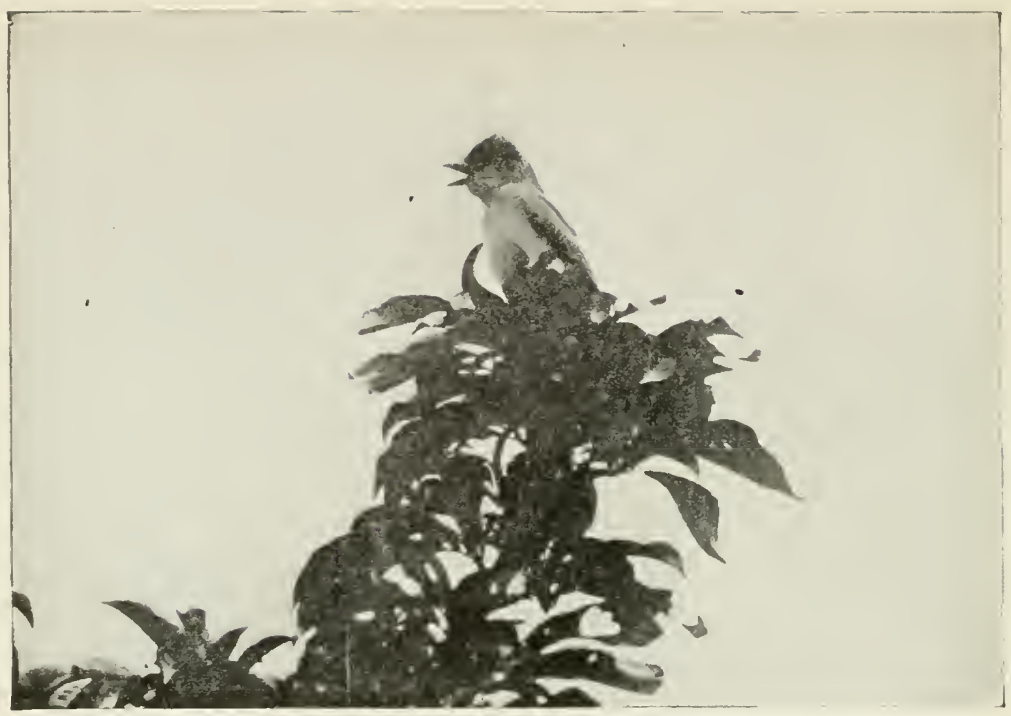

Kingbird scolding. "Indignant when any one comes near the nest" (p. 197).

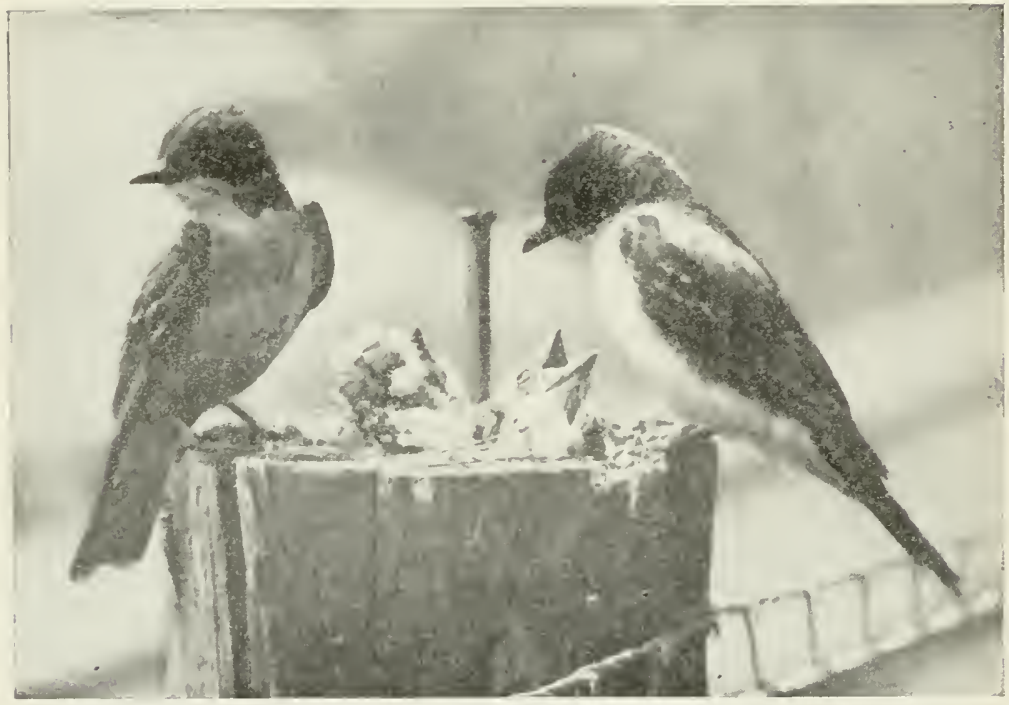

The entire Kingbird family. "The young begged hard for food" (p. 196). 


\section{PROFESSIONAL FLY-CATCHING}

their own business, but she had no use for inquisitive persons.

The top of the post, I found, had become rotted out in the center, forming a nice little cup. In this the birds had built a very frail nest, nothing like the bulky one they usually make, and the female had laid the three usual handsomely blotched eggs. Besides being so close to vehicles passing on the road, on the other side the railway trains whizzed by within a yard of her, and altogether it was a most remarkable situation for birds which usually prefer an orchard. Right across the road was an apple orchard, just the place for them, one would think, but the queer selection they made was no one's affair but their own, and I am glad they made the choice they did.

I was afraid that, in such a public place some miscreant would break up the nest before I could get photographs. Bright and early the next morning, the first day of July, I drove down there, and was delighted to find everything all right. 'The mother was incubating, but she would not let me walk up to her with the camera. So I set it up on the tripod reasonably near the nest, and went off a little way with the thread. After some hesitating and flying angrily at the camera, the bird decided that it would not hurt her, and settled down upon her egrgs. Of course I "got" her, and after" this she would come back almost at once, and I soon had as many pictures of her as I wished, in all sorts of positions. While I was working, an express train 


\section{PROFESSIONAL FLY-CATCHING}

went thundering by. The concussion of the air almost blew her off the nest, but she hung on and sat as firmly as a cowboy in his saddle. It was usually the same story, though once she left when a blundering freight was half way by.

The best fun came when the young were out and about half grown. The mother, I think it was, usually stood beside them, sometimes shielding them from the sun, for there was no shade whatever. There was a pond close by, and the father spent most of his time watching the dragon flies darting about over the water, now and then giving chase to one. They were nearly a match for him in flight. Sometimes he would fail and go back to his perch, but often enough he captured his prey. As he approached home with his prize, he always chattered a sort of triumphal march to announce his coming. If his mate was not on the nest, she hurried to it, both arriving at about the same time. The young begged hard for food and their father would begin to feed them. But mother yearned to assist, so she would often lay hold of the dragon fly and pull away till she had torn off a piece, which she would then feed to the young. Meanwhile the camera was in place and all ready, so at the favorable instant at clifferent stages of the process I pulled the thread and thus secured a fine series of pictures.

Of course Ned had to come in for his share of the fun. One day I sat down in the shade and watched him while he took my camera, set it up by the nest, 


\section{PROFESSIONAL FLY-CATCHING}

focused, put in the plate, removed the slide, attached the thread, set the shutter, and made the exposure when the birds were feeding. One that he got was especially fine, showing very plainly the dragon fly with its long gauzy wings held by the bill of the male, and "getting" the whole family at one shot.

To my great satisfaction no one molested the Kingbirds, though everyone in the neighborhood knew of the curiosity. I saw them the afternoon before they left the nest for good. The little fellows looked very pretty with their snow-white little shirts, standing up on the post with their mother beside them, and I got a snapshot of them thus with my reflecting camera as I walked along the road past them. With some difficulty I obtained another picture as the father fed them, but the old birds were shier of the camera now, and the young were not fed so often. I praised the boys for not disturbing the nice family and promised each of them a picture.

Nearly everyone knows how boldly the Kingbirds defend their nests and has seen them chase the thieving crows, flying at them from above and pecking them sorely as they try vainly to escape. They even keep off hawks from the farmer's premises and destroy such a multitude of insects that it is a fine thing to have a pair of them located in the orchard. So indignant are they when anyone comes near the nest that I have taken advantage of this to snap them with my reflecting camera. I use a single "22-inch" lens of my eleven- 


\section{PROFESSIONAL FLY-CATCHING}

inch-focus doublet, and an aperture of the curtain of about an inch and a half, with a moderate speed. Taking the bird perched upon a branch, one can thus get a good large image with plenty of detail in bright sunlight.

The Kingbird gets its name from its pugnacious ways when it must stand for its rights. It does not, however, bully other birds without good reason; vet, when it decides to assert itself, it is usually able to enforce its simple requirement that the undesirable intruder shall "get out." It has fighting blood in its veins, for all the other species of this distinct and interesting order of flycatchers are good fighters. Their main business is to catch flying insects, and they all have their art down to a fine point. Their method is different from that of the swallows, for instead of keeping long a-wing, as the latter, the true "flycatcher" stations itself on some perch which commands a view, like a hawk, dashes to catch the unwary insect, and returns at once to its observatory. Various other birds dart after flying insects, but have other means of livelihood, while the "flycatcher" confines itself largely to this one way.

We have another "Tyrant Flycatcher," which probably is equally tyrannical with the bird that bears the royal name-the Crested Flycatcher. Few people know it, for it is rather scarce and very shy. Though it generally chooses orchards for residence, it prefers those that are abandoned or off from houses, at the edge of the woods. Even there it is rather hard to see the 


\section{PROFESSIONAL FLY-CA'TCHING}

bird, which is about as large as the Kingbird, for it gets out of the way when it notes our approach; but its presence may be known by the single loud ringing whistle which is different from any other bird note I know. They nest in a hollow limb, and it is notorious that in building they almost always use cast-off snake skins. The eggs are very handsomely and heavily marked with lines and scrawls.

There are two common flycatchers which are liable to be confused, the Phœbe and the Wood Pewee. Both are small gray birds with whitish and partly dusky breasts. The Phobe is our familiar home bird which builds its nest of moss and mud under some sheltered part of our buildings, even over our very door, or under the piazza. The Wood Pewee may also be seen about the premises, but it keeps to the tall shade trees, where it builds a frail lichen-covered nest flat on some branch or fork. It is a good deal like the architecture of a hummingbird and is just about as hard to discover. The note of the Wood Pewee is that clear plaintive whistle- "pee-wee-ee"-and we surely know the short, throaty note "phe-be" of our Phœebe. Another way of distinguishing the Wood Pewee is that it is rather more slender than Phobe, generally with a darker breast, and it seldom jerks its tail, which last it is Phøebe's constant delight to do.

The Phœebe is a hardy bird and comes back for the summer at a very unsummerlike time, the last week of March, setting one to wondering how it finds flying 


\section{PROFESSIONAL FLY-CATCHING}

insects in such cold weather. Yet notice on the sunny side of the building, when the sun shines brightly, how many flies are buzzing about, which proves that there are flies, if one only knows where to look for them, and surely our professional fly-catcher knows that much. But if anyone claims to have heard a Phoebe back in mid-winter, do not believe it, for the Chickadee makes a "pewee" note, and many are the people who are fooled and publish their mistake in the local paper. IVe are safe to assume that, no flies, no Phœbes.

The hardy bird has its nest built some time in the latter half of April, according to the sort of season that prevails, and lays five white eggs, sometimes sparsely spotted. Before the country was settled, the usual nesting place was under an overhanging rock, and even now some of them keep up the old custom. I have discovered a number of such, and Ned found one close by where I was photographing the nest of another bird, a little way below the foot of a beautiful waterfall.

For the past three years a pair of Phœbes have nested in my barn, and reared two broods of young each season-six broods in all, laying five eggs the first time, and four the second, and usually hatching and rearing them all, or all but one. The nest was on the projecting end of a board nailed across two ceiling beams, just over where I drove in with the horse and buggy. Each year the Phøebe found the old nest all right, so she used it five times in succession, but this last time she built another nest at the other end of the 130 


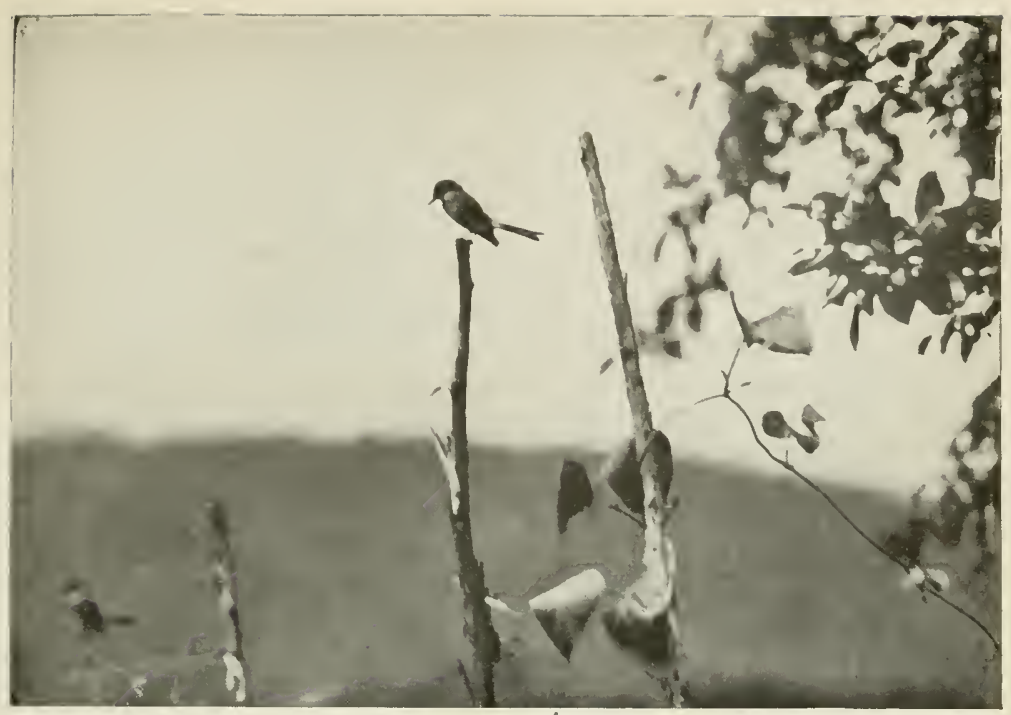

Phœbe and her new husband in the garden (Pp. 131-2).

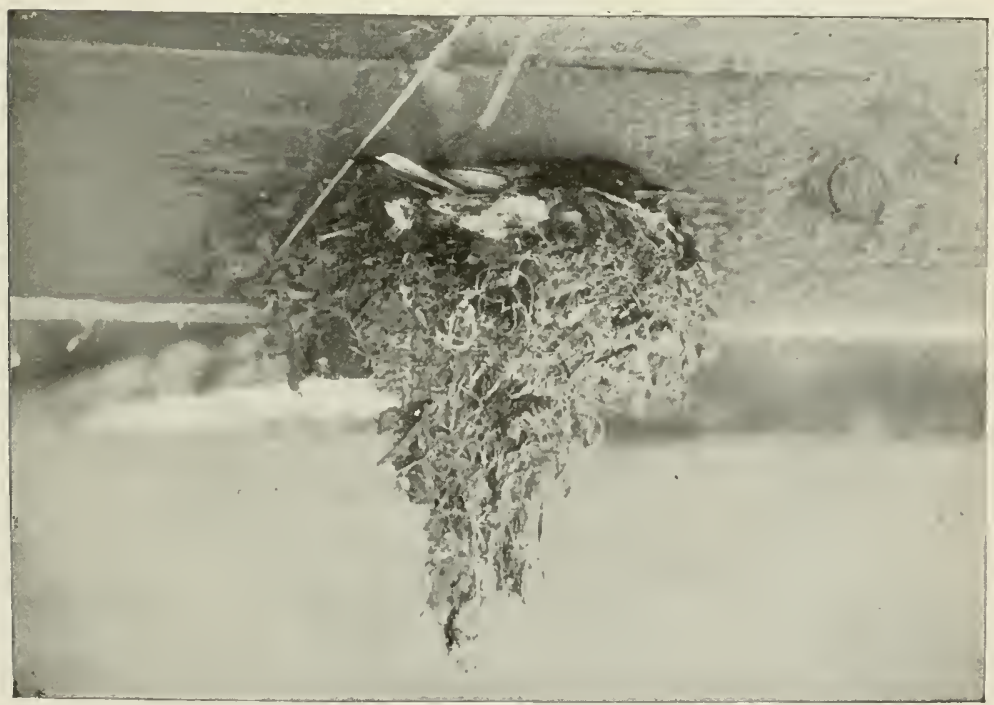

Phœbe on nest. "Nested in my barn" (p. 130). 


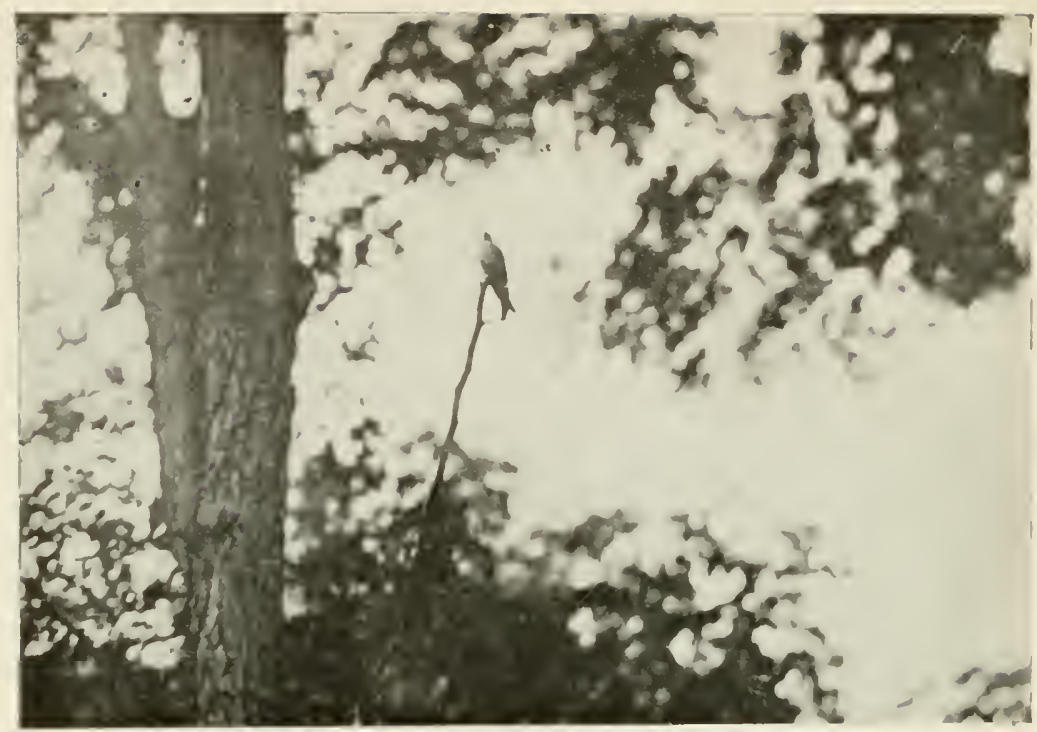

Snaprlut of ITood Pewee. "Is she perched on dead stubs" (p. 133).

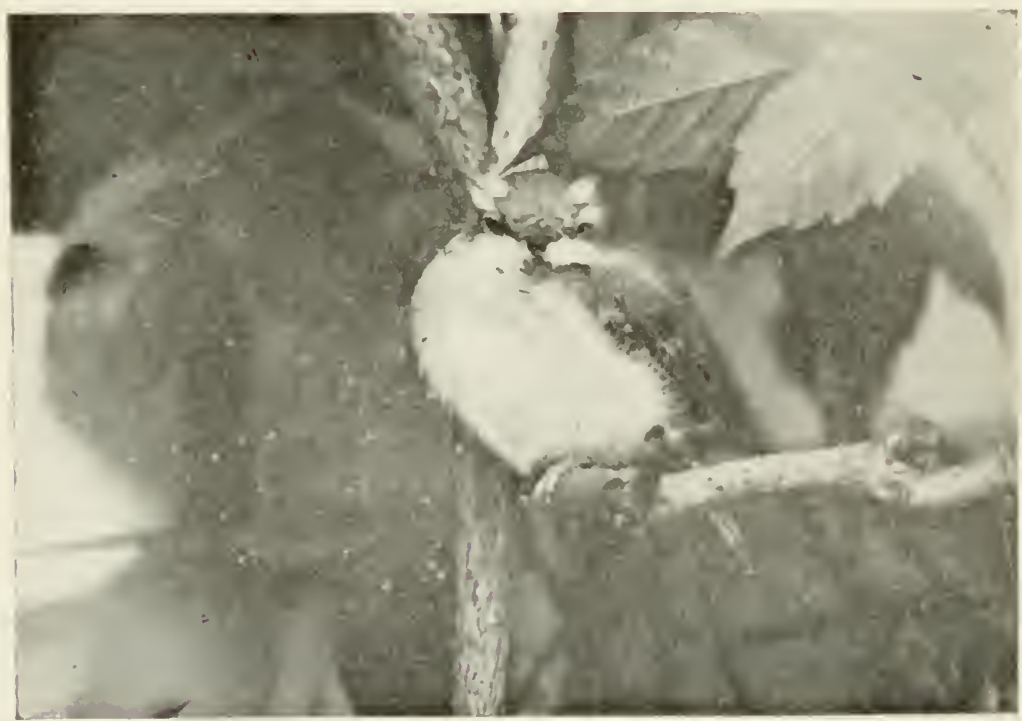

Soung Least Flycatcher. "They call it "Chebec"" (p. 13t). 


\section{PROFESSIONAL FLY-CATCHING}

barn in a similar situation. At first I wondered why she deserted such a nice nest, but I found out. One day I put my hand into the new nest to see how many young there were, and presently I began to scratch my head. Oh, how I did itch all that night! My suspicions were aroused, so I touched the young again, and looked at my hand. A whole army of lice were hurrying to run up my sleeve and I fled to the water faucet and put a stop to the migration. Ned does not see how the young can stand it, and neither do I.

We both photographed the Phobe bird on the nest. The way I did it was to bring three barrels nearly under the nest and set up the tripod with full extension, so that the camera was away up to the ceiling. Standing on a step ladder, I could focus on the sitting bird, but the light was so dim that I had to set up a large mirror outdoors and throw a sumbeam on the nest. Then I could make short exposures on her, or remore the mirror and make the exposure last two minutes. The dear little bird sat perfectly still, and I liad the best results the latter way; the picture was not so harsh.

In the early spring, this last season, soon after the Phœbes arrived, a sad accident occurred. It was a windy day and I saw the barn door slam violently. I was minded to go and prop it, but kept on and did not. Later in the afternoon a member of my family brought in the dead body of the male Phœbe, still warm, with his neck broken. The little fellow had alighted on the door, and it caught him as it slammed. 


\section{PROFESSIONAL FLY-CATCHING}

I felt very sorry, for I thought that now there would be no Phobes in the barn. But in a few days I saw the female on the old nest, preparing to lay, and her mate perched on the apple tree by the door. Husbands were evidently plenty and cheap, especially for a rich widow with such fine property. The new bridegroom looked exactly like the former one, and our mourning was turned into gladness.

That same season another tragedy occurred in the family of a pair of IVood Pewees. These birds are not so hardy or so early in nesting as the Phœebes, and it was not till the middle of June that I noticed, in driving frequently through a grove of locust trees, that a pair of Wood Pewees were always there in the same spot. "I declare, Ned," I exclaimed, as we drove past again and saw a Wood Pewee in the accustomed place, "there must be a nest right here, and I'm going to stop and look." So I got out of the buggy and immediately saw the shallow nest built over a crotch of an extended branch over the road above my head, about twenty feet above the ground. It contained two young.

We could not stop then, but a few days later we returred, hoping to photograph the nest and get snapshots of the old birds, which were not shy. First I got out the reflecting camera, and had Ned climb the tree, hoping that the female would come at him and let me snap her with my twenty-two-inch lens. But she was a meek little body and merely wailed her "pee-ee-ee" from the surrounding trees. I had to chase her around 132 


\section{PROFESSIONAL FLY-CA'TCHING}

for half an hour, but got some quite good snapshots, as she perched on dead stubs where the sunlight happened to strike on her through the leaves.

Then we turned our attention to the nest and Ned's sharp eyes were the first to discover that the whole botton had fallen out and one of the young had tumbled through, had become entangled, and dangled dead from the bottom of the nest. Nothing was left of it but the rim and the other youngster was perched upon that. I failed to get any satisfactory photograph, as the only possible location for the camera was too far away to show so small an object, and the brittle locust limb would not bear one's weight. The next time I went by, the dead young one had disappeared. The other stayed on the rim of the nest or the branch for some days. Then came a terrific wind and thunder storm, and the next day, when I passed, the youngster was gone, probably blown off and drowned, poor thing!

There is another flycatcher closely related to the Wood Pewee, the Olive-sided Flycatcher, which we may look for only in the migrations as it usually goes further north to breed. It looks much like the Wood Pewee, but is larger, nearly the size of the Crested Flycatcher. It is rather rare and I have only met with it a few times, generally seeing it chasing ties from some perch in a high tree on the edge of woods or along a shaded, retired road.

Except for the Kingbird and Crested Flycatcher, all our flycatchers are dull-colored gray and white birds, 


\section{PROFESSIONAL FLY-CATCHING}

A-id some of them are hard to tell apart. Those already spoken of can be distinguished by differences in size or build, but there are several little fellows which are so much alike that it takes a sharp eye and careful study of the Handbook, to identify them. Those which may cause confusion are the Alder, Acadian, and Least Flycatchers. The Yellow-bellied Flycatcher may be recognized by what its name implies. The Acadian Flycatcher, a greenish-hued little bird, is seldom seen north of the Middle States.

Of small species the Least Flycatcher is by far the best known. It is the familiar little fellow that nests in orchards and shade trees, and it is constantly repeating its sharp, scolding note, from which they call it "Chebec." One year, in June, I was about to start on a trip up north into the Province of Quebec, and every morning one of these little birds, perched just outside my open bedroom windows, would begin at the first early ray of dawn and wake me up by calling out "Quebec, Quebec." We had a lot of fun over it, because members of my family said the bird was very anxious to get me off to Quebec so that I should not be annoying it with my camera-fiend tricks.

The nest is apt to be out on a slender branch and is not easy to photograph. But I took pictures of one with a brood of young about ready to leave by standing on a ladder, against which I leaned the camera on the tripod and managed to keep it still enough. Another time there was a nest out on the end of a branch of a 


\section{PROFESSIONAL FLY-CATCIING}

pear tree, about a dozen feet up. I secured the picture of the mother bird incubating by standing on a stepladder with my reflecting camera and the big lens, having a young lady throw light upon the subject, not by means of her discourse or countenance, but by a mirror which reflected a sumbeam upon the shaded nest.

All my life until the past June I had never been able to find the nest of the Alder Flycatcher-which is a recent name for the eastern form of the species long known as Traill's Flycatcher. A friend of mine in a town not far from where I live, at a higher elevation, finding this interesting little bird quite common there, invited me to visit him and see the rare flycatcher and its nesting. They are late breeders, seldom laying before the middle of June, and I did not go till the twenty-seventh.

The bird is known to be one of the most timid and secretive of the smaller species and to frequent alder swamps. I had always supposed that the place to look for it was in dense alder thickets, so I was quite surprised when my friend conducted me into a moist pasture where there were only scattered branches of low alder bushes, most of them not over a yard high. In one of these he had located a nest some days before, in process of building. Here it was now, only a foot from the ground, with one pretty, pinkish egg with reddish spots around the larger end-a neat nest, not unlike that of the Chestnut-sided Warbler. The owner did not appear. 


\section{PROFESSIONAL FLY-CATCHING}

We spent the rest of that day with other birds and the next morning went to another nest site, in a pasture through which flows a large meadow brook. There were scattered clumps of alders, some of them of good height, but plenty of small ones, too. This nest, however, was not in an alder, though close to some, but in some other sort of bush, two feet from the ground. It contained four eggs, slightly incubated. They were warm, but the shy bird had slipped away. Setting the camera, well concealed, in the next bush, for a short timed exposure, with thread attached, we went off for over an hour to give the bird a chance to return. The Alder Flycatcher is so very shy that I had my doubts as to whether she would ever return to the nest with a camera near it.

When we returned, I crept up within twenty yards of the nest to where I had left the spool and pulled the thread. The eggs were warm, so the bird was doubtless on when the shutter opened. Yes, and to my horror it was still open and the plate spoiled! Taking apart the shutter, I found that some of the delicate mechanism had collapsed and that photography was all up for the present. Luckily the jeweler in town was able to repair it, and early the next morning, my last day there, I was at the nest. It was cloudy so I had to allow for a half-second exposure.

After setting the camera I made a slight opening in the bushes so that I was able to watch the nest with my strong Zeiss glass trom quite a distance. To my de- 


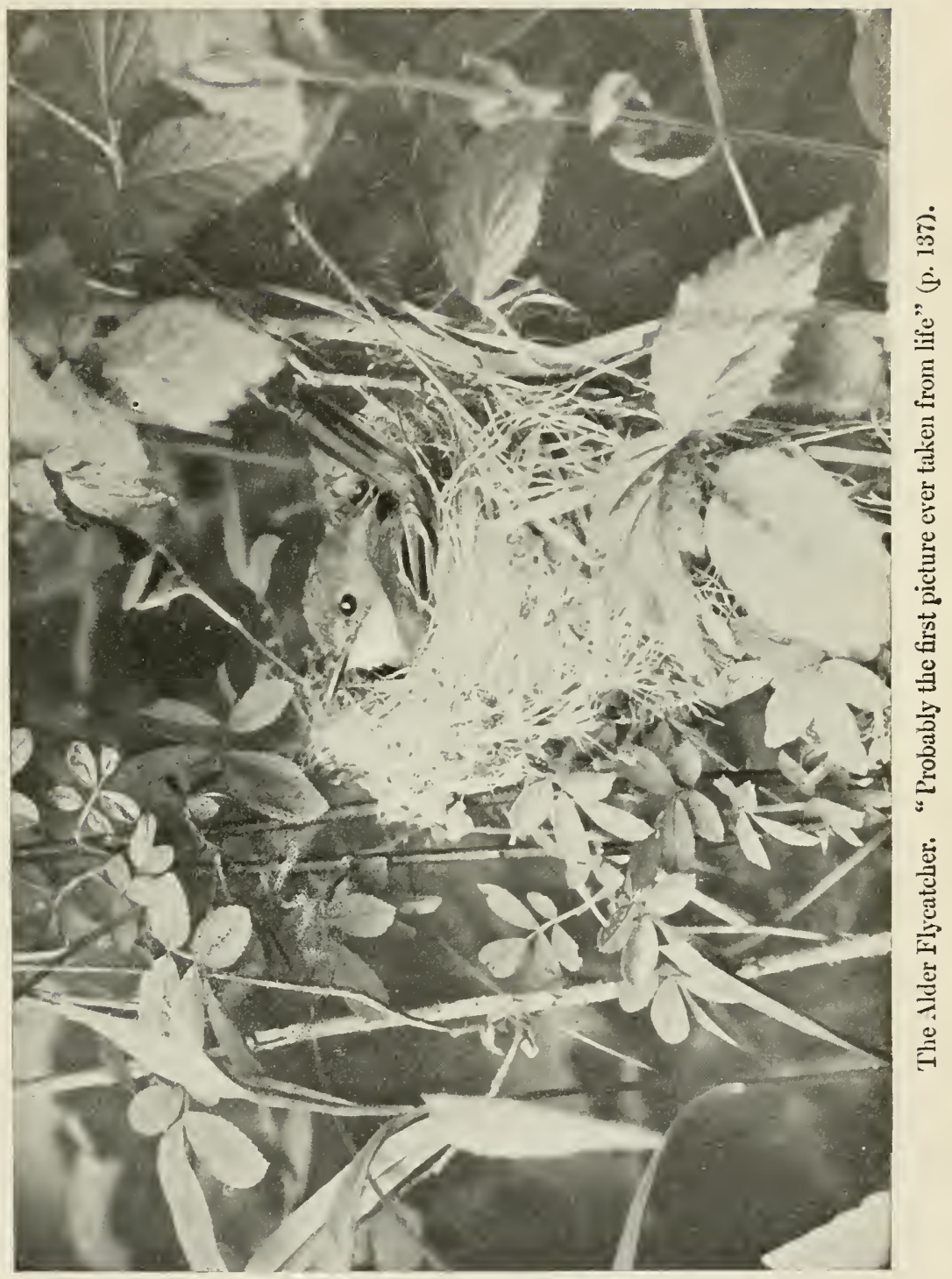




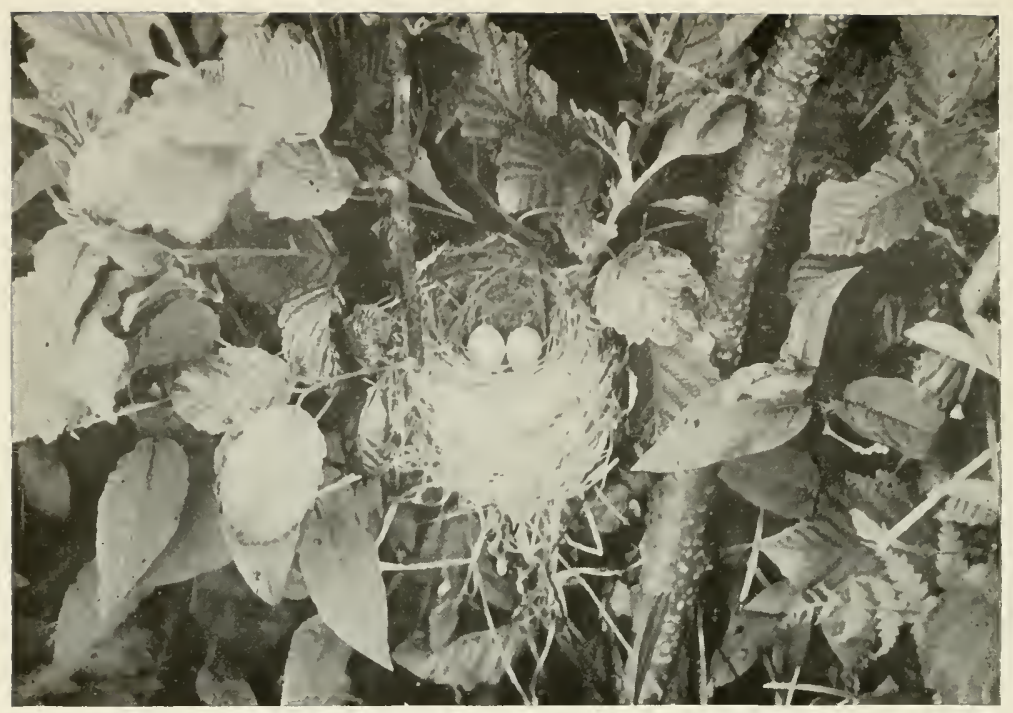

Typical nest of Alder Flycatcher (p. 138).

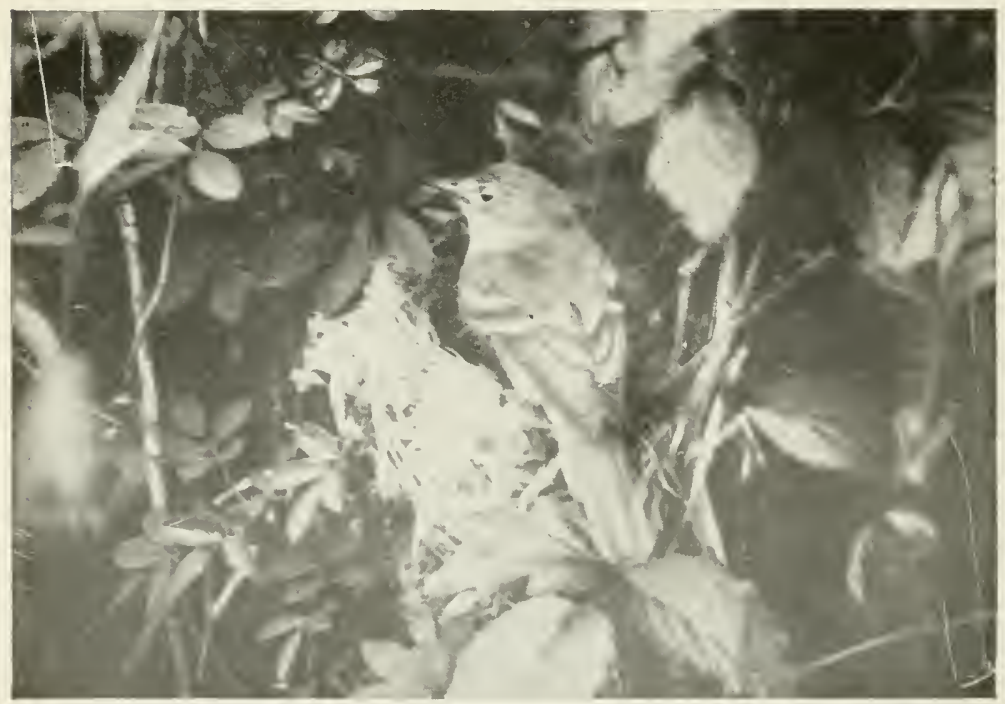

Alder Flycatcher. "As she stood erect on the rim of her nest" (p. 13ㅍ). 


\section{PROFESSIONAL FLY-CATCHING}

light, within five minutes the bird hopped back on to the nest and did not move at the click of the shutter.

To make this story short, I repeated this operation a dozen times, securing a fine array of pictures, probably the first ever taken of the Alder Flycatcher from life. The camera was within a yard of the nest and I used the single twelve-inch lens. The bird became so accustomed to my presence that she would return to her task sometimes the moment I withdrew. I could walk up within a few feet of her as she sat on the nest, and once she let me change the plate and photograph her by hand without leaving. The last few times I pulled the thread as she stood erect on the rim of the nest preparatory to descending into it.

Evidently the shyness of the Alder Flycatcher is not unconquerable and is due rather to a natural timidity than to dislike for our sort of people. But shy the bird certainly is. Except for this one drawn to the nest by maternal instinct, it was hard to get even a glimpse of them. They are very silent, too. The only sounds I heard from those intruded upon was a very soft, low "pweet." In the distance the song of the male was hardly audible, if, indeed, it deserves to be called a song, only two syllables like "pe-weet."

Leaving this spot, perfectly delighted at my success, I drove to the other nest to see if the eggrs were laid and how that bird would act. Other birds that I met delayed me, and, missing the exact clump of alders, as there was not time for a careful search I was about 


\section{PROFESSIONAL FLY-CATCHING}

to give up, when I put my hand into the very last likely clump of small alders in the open, at the edge of a high alder thicket. I almost touched a bird, which darted off in a great fright. Actually it was another Aldel Flycatcher's nest, with two eggs, within only a few yards of the one I had missed, situated much as was that one-so much so that I would not have believed it the same, only it was on the opposite side of the clump. Just then it began to rain, but I managed to take two photographs of it, and, by driving fast, barely caught my train to return home. 


\section{CHAPTER IX}

\section{CROW RELATIVES}

(Crows, Jays, Blackbirds, Orioles, Larks)

OTARTING off bright and early that elegant $\$$ morning, the fifteenth of May, Ned and I drove twenty miles over the roughest sort of roads through a wild hill country and explored many a fine timber tract. It was just the day for active exercise, bright, but with a cool easterly breeze. Hosts of interesting bird migrants were streaming through on their way north and kept us busy identifying them. We found five occupied hawks' nests with eggs, and it was a great day for crows' nests, too.

In the second piece of woods which we tackled, we were searching for a hawks' nest, which we found a little later, when I discovered a large platform of new sticks about thirty-five feet up a hemlock tree, with a bird's tail sticking out over the edge. At first we both thought it was the hawk, but the glass showed the plumage to be "black as a crow," and crow it was. It was no come-down either, for I especially wanted a really good photograph of a nest with a brood of young crows. The old bird was sitting like a rock and 


\section{CROW RELATIVES}

would not leave till I rapped the tree. Then I went upstairs to the nursery, after strapping on the climbers, and found three ugly, nearly naked young. They were too small to work upon successfully, so I left them to grow larger.

After this we drove up a long hill through the woods. The timber was mostly small, but we came to some that was of good size, where we hitched the horse and took a scramble up the steep hillside. In a few moments I saw a large nest high up in a large chestnut tree. A crow was brooding on this one, too, and she was as loath to depart as the other bird. The nest was so inaccessible for photographing that we did not climb, but drove on a number of miles further, devouring an ample lunch, as we proceeded, with keen appetites.

The next tract which we decided to explore was a grove of moderate-sized oak timber which proved to be smaller than I had thought, and I was at first sorry that we had bothered with it. There were several squirrels' nests, and presently I saw a nest that looked promising. It was only about twenty feet up a slender young oak, and there was a bird on it, a crow, I saw, as I came nearer. Beside her, at the edge of the nest, I could see some bright red objects which puzzled me until I made out that they were the widely opened mouths of young crows which were poking out their heads from under the brooding mother and begging for food.

The old bird left when I came very near and I saw 140 


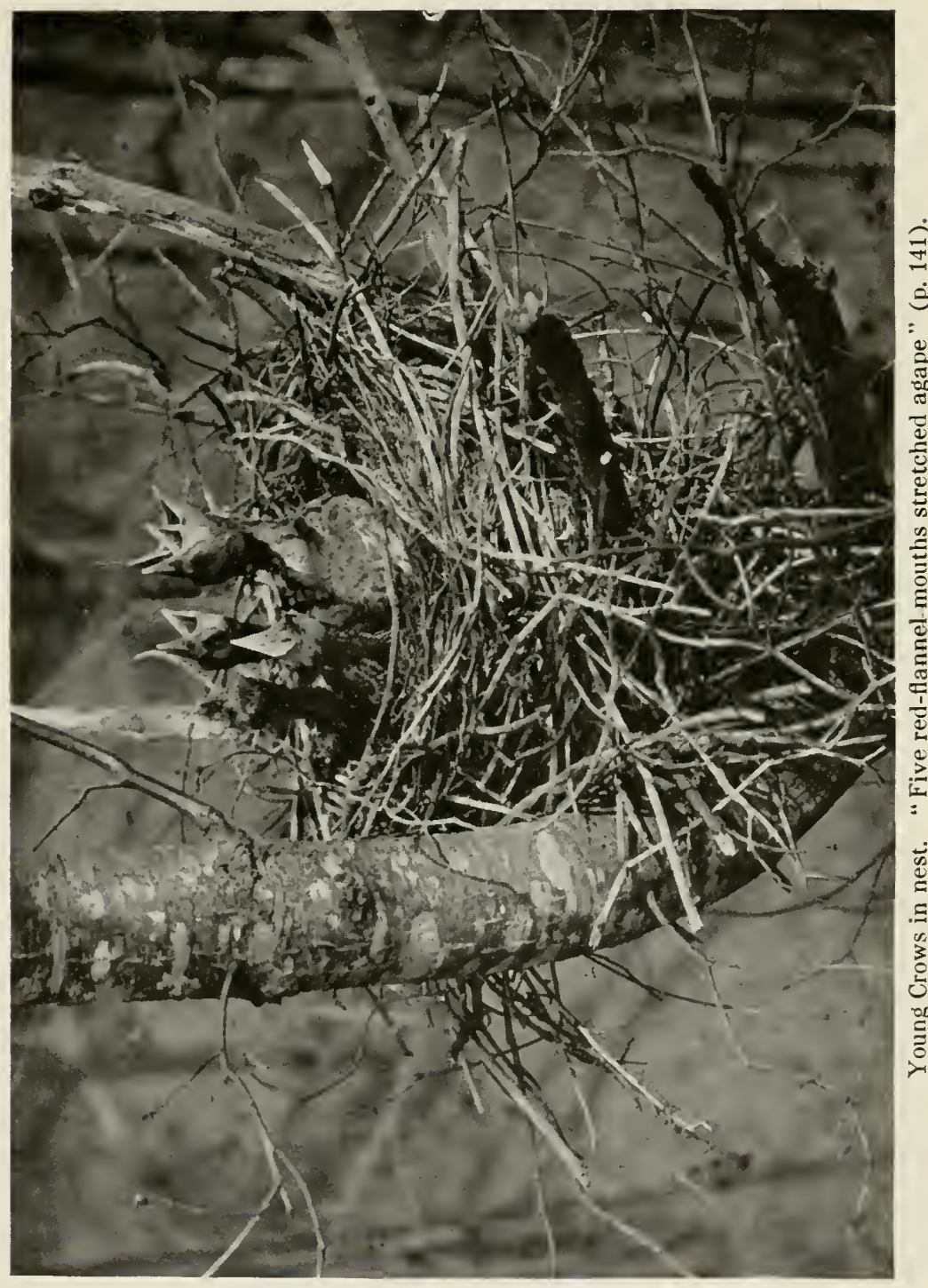




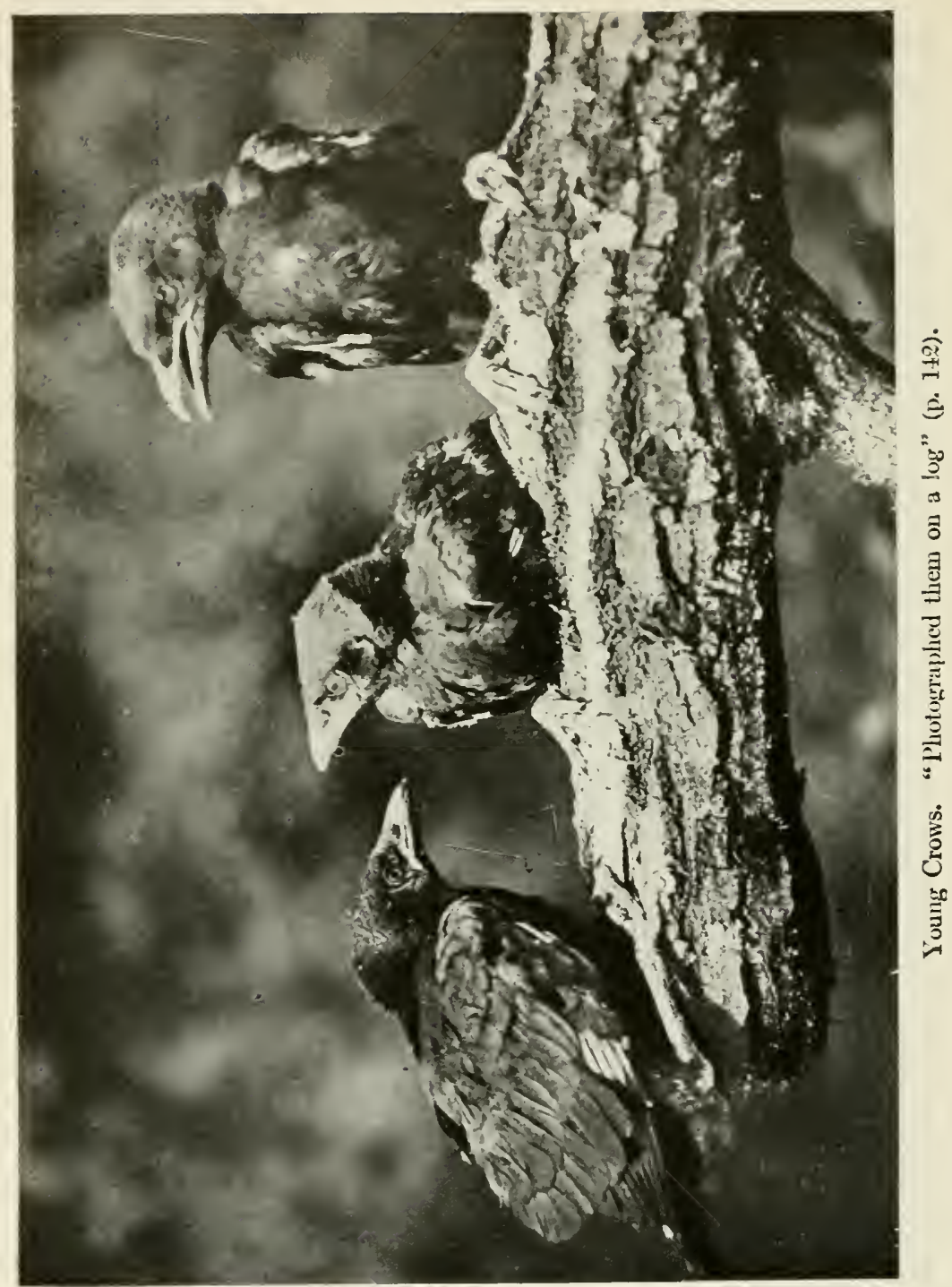




\section{CROW RELATIVES}

that here was a splendid chance for just the picture I wanted. Another small oak grew close alongside the one with the nest, at just the right distance and in the right direction, on the sunny side of the nest. Ned ran to get the small camera and the tree apparatus, while I climbed the tree next to the nest and looked in. Five hungry little crows, nearly fledged, raised their heads and opened their mouths as wide as they knew how, beseeching me to appease their gnawing appetites. Pretty soon Ned came back with the camera, and, after going down to get it and climbing back, I went to work to serew it up. It took certainly a quarter of an hour to make everything ready. By this time the youngsters had settled sleepily down into the nest and would not rouse up to beg for food, till I bethought myself to cut a switch and stir them up. No sooner done than, presto, up popped five black heads, with five red-flannel mouths stretched agape, from which were issuing excited caws, because they thought that mother had arrived. Instantly I squeezed the bulb and had them just as I wanted them. I barely had time to finish the work when it clouded over darkly, so we drove off.

I planned to photograph these youngsters again when they were about to leave the nests, so I drove back there alone some days afterward. But I had waited just too long. My subjects were there, but they had left the nest and could fly from tree to tree, so that it would have required the help of a gun to capture 


\section{CROW RELATIVES}

them. On the way home I visited the other two nests, but the young had left the one in the tall chestnut, and in the hemlock nest all that was left was about half of one of the young ones. My friend the hawk had been finding the gentle art of eating crow not as disagreeable as some suppose. This was proper enough, in all justice, to avenge the pillaging of many a small bird's nest by the black rascals.

The only way that I knew of at this late day to get young crows to photograph, was to hustle and find some. Truly I worked hard, but I had no success till I came across a friend who recently, while resting in some woods, had seen a crow fly to a nest in a low fork of a big chestnut tree. One may be sure I lost no time in having him show me the nest, the only delay being to examine the nest of an Ovenbird which fluttered from her eggs almost at my feet. All was silent at the crow's nest, but I took the camera with me up a sapling which grew beside the other tree, and saw three young crows almost fully fledged squatting low in the nest. They were too old to beg for food, having learned to fear, so I photographed them as they were, in the nest; then I climbed to the nest, took them down in a creel, photographed them on a log, and restored them to their home, though my friend was for wringing their necks. After I was gone I suspect that they went the way of all the world!

Although the crow is usually a shy bird, it is perfectly possible to photograph it at the nest, provided that one 


\section{CROW RELATIVES}

find a nest favorably situated. I have not attempted it owing to pressure of other work, but once I placed a dummy camera close to a nest with young, and the old birds soon learned to ignore it and fed their offspring. In the West the crows are much tamer than here in the East. Out in North Dakota, I have been able to walk within a few steps of crows incubating in low trees, and it probably would not have been very hard to photograph them, had I been able to take the time.

Everyone knows how tame they become in severe winter weather when the snow is deep. Chilled and emaciated, they come close to houses and barns seeking food. Some years ago one came to a city street so exhausted that it could not fly, and I rescued it from a gang of cruel boys who were kicking it to death. I saw the remains of one on the snow in the woods, which a fox had eaten, as was shown by the many tracks, and they sometimes fall victims to hawks and owls. Near a certain hawk's nest recently, one lay dead on the ground, with the flesh of its breast torn out. Next day nothing was there but a few feathers.

They breed quite early and it is time to find their eggs during the last half of April. In regions where there are pines they build in these, and high up, where the nests are generally hard to see from the ground. In such country as that where I now live, pines are scarce, and Ned and I hunt for crows' nests in deciduous trees or hemlocks. 


\section{CROW RELATIVES}

Most people do not realize that the Blue Jay is a member of the Crow family. But it is, and has all the mischievous, destructive, thieving instincts of the crow, and with a lot of audacity, or "cheek," thrown in for good measure. It robs the nests of other birds and is very unpopular with them. The appearance of a jay about their homes is the signal for the breaking forth of a general clamor, till the rascal, seeing that it is found out, beats a retreat. Hardy, like the crow, it is found throughout the year. Ordinarily it is rather shy abou' making friends with man, but it often shrewdly senses when it is wanted and comes to him for food in cold weather. A friend of mine puts peanuts in the shell out on his piazza roof, and early in the morning I have watched the jays come and eat down the peanuts whole, shucks and all.

The Blue Jays' nest is a rather neat structure of twigs and rootlets and is built in some low tree in woods, swamp or pasture, and generally by early May contains four or five dark spotted eggs. Now and then a jay, especially when the young are hatched, is very bold in the defense of its home. There are many cases where the bird has braved the intruder and even allowed itself to be handled. But I have not yet had the good fortune myself to meet with such an individual. The nearest I came to it was with one which I found incubating on the first day of May in a low crotch of a small tree at the edge of the woods, about as high up as my head. This jay allowed me to step up on a stump 


\section{CROIV RELATIVES}

six or eight feet from her, but only because I moved very slowly. At that time I had a camera with only a small lens and short bellows, and the best I could get was a small picture, as she would not return while the camera was set up near the nest.

Various friends of mine have beaten me on Blue Jay pictures, but some day I hope to get even with them. I tried to do this last spring and had most exasperating luck, though I made an encouraging start, finding three nests the first day I looked. Early in May I was going to a hawks' nest and passed some pasture cedars, bordering the woods, when I saw a jay go skulking from them. There was a nest near by, just ready for eggs. This set me to searching the cedars-always a favorite resort for jays-and further along I came upon a jay sitting on four eģ̧s, and further still another on five. The birds were all shy, and, strange to say, a few days later, every nest was deserted or robbed. This only made me the more determined, and, one after another, I found six more nests, nine occupied nests in all, besides several other new ones that had been recently abandoned. But to be brief-not one of these pairs raised its family. Only three of them hatched, and in these cases the young disappeared before they grew a feather. I had not disturbed them in any way, save one pair at whose nest I set a dummy camera awhile, and I charged the mischief upon crows or other jays, though I have no means of definitely knowing. All I could do in line of pictures was to 


\section{CROW RELATIVES}

get a few snapshots with the reflecting camera of the jays that had young, as they scolded from the foliage above me. I shall keep on looking, though, and some fine day, I expect I shall find a bold pair of jays after my own heart. If Ned should succeed first, though, I know I should never hear the last of it.

There is a group, or Family, of birds which comes next after the Corvidæ, or Crows, called Icteridæ, which means oriole-like birds. It includes the various blackbirds, so that it is easy to think of them along with the crow. One of its members is the Meadowlark, which is really not a lark at all. The Family of true Larks comes in the classification just before the Crows, and, as we have just one species, we may as well mention it here with the Meadowlark. It is the Horned Lark, or Shore Lark. During the winter months they come down to us from the cold North, especially along the seacoast, on beaches or sand dunes. How I have enjoyed midwinter seashore strolls, and this pretty lark, with its salmon tints, black half-moon on the breast and curious little feathery "horns." They go in scattered flocks, often with the handsome white Snowflake, or Snow Bunting. We trace them by their mellow chirpings and find them here and there among the beach grass, picking up the seeds. Like enough we alarm them and away goes the flock all at once. For a while they circle about in the air, and finally return, perhaps, to nearly the same place. Inland they are not so common, yet we are 146 


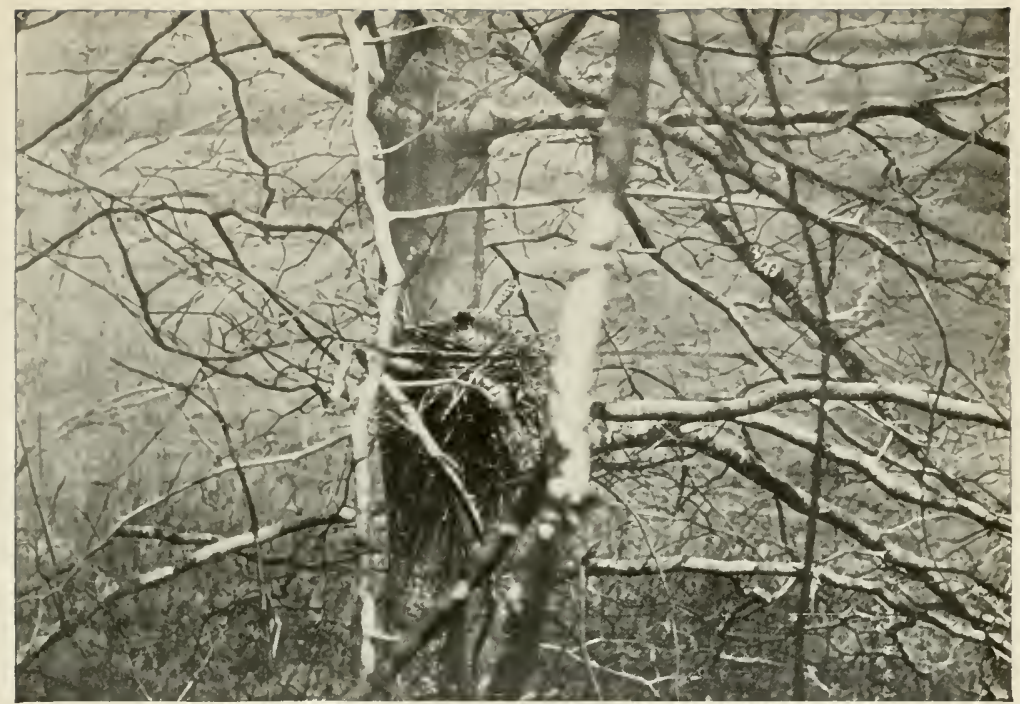

Blue Jay. "Incubating on the first day of May" (p. 14t).

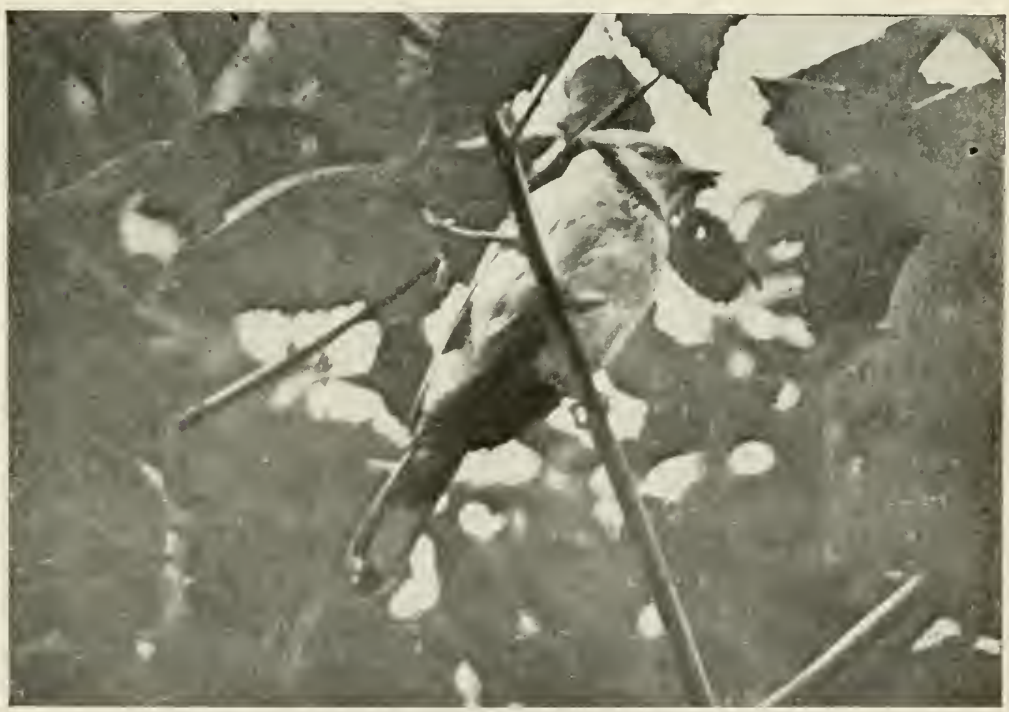

Blue Jay. "Scolded from the foliage above me" (p. 146). 


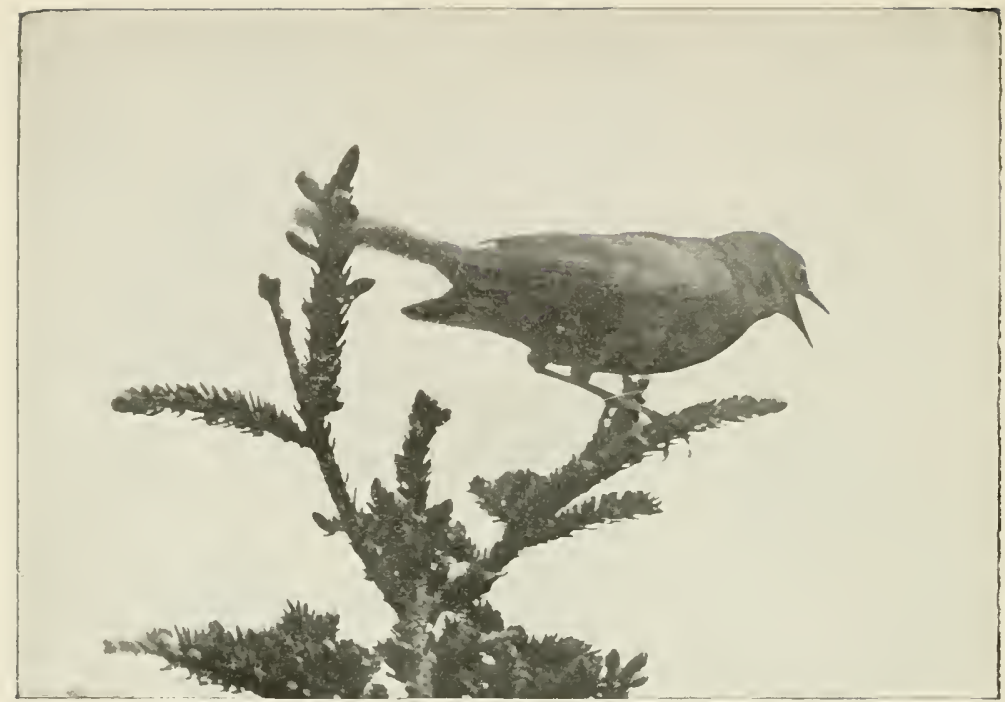

Rusty Grackle. "Emitting a flood of saucy expletives" (1. 15j).

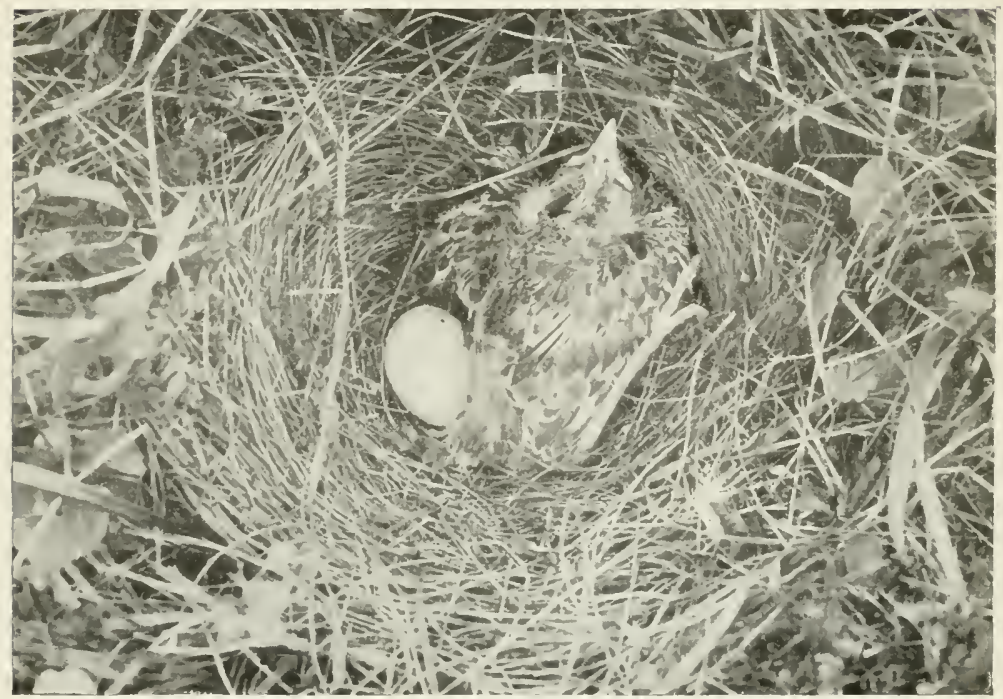

Nest of Meadowlark. "Mhotographed what was left" (p. 148). 


\section{CROW RELATIVES}

liable to run across them now and then in winter, in open fields, especially with flocks of Snow Buntings. There is also a pale Western form of this species called the Prairie Horned Lark. This occasionally breeds with us anywhere in the East, frequenting dry fields and barren pastures or hillsides. If one see a pale, bleached-looking lark, look out, for it is something worth while! A pair stopped one spring late in April about two miles from where I live. Ned kept track of them for me and often heard their sweet warbled songs. We surely thought they were intending to breed and spend the summer, but in two weeks they disappeared.

In these same fields the Meadowlark is found, fairly commonly, but not as much so as it used to be. Formerly it was hunted as game, but now it is protected as one of our most valuable destroyers of grubs and insects that damage the grass land. About the middle of May they have eggs in a well-concealed nest in a bunch of dry grass, arched over on top. The male is very watchful and gives his sitting wife the alarm when he sees anyone coming, and at once she sneaks off without flying directly from the nest. Consequently the nest is very hard to find. But now and then I have taken the sentinel off his guard, especially in the evening, and by mere chance flushed the female from her eggs when I had almost irodden upon her. The farmer in mowing his fields is the most apt of anyone to find this hid treasure, for the bird often rears two broods, the last even as late as July or August. One 


\section{CROW RELATIVES}

farmer showed me a nest late in August which a day or two before I saw it had contained two unsound eggs and two young birds nearly grown. When I came, one of these had traveled off in the grass on hir stout long legs, and somehow an egg had disappeared, but I photographed what was left, glad enough of the chance.

The Western form of this species, called the Western Meadowlark, is a beautiful singer and is perhaps the most beloved of birds to the settler upon the vast prairie. And I, too, on my expeditions, have enjoyed them and their fine music.

Next come our Orioles, and not everyone knows that we have two kinds. The brilliant Baltimore Oriole that builds its remarkable hanging nest from the tips of the elm boughs along our shaded town or village streets is the one that is so widely known. Very promptly each spring on the fourth to sixth of May, Ned and I hear its clear notes again, after its long trip to South or Central America and back since we last saw it. As with many birds, the males arrive some time before the females. But before long they are all here and mated, and then begins the making of their very remarkable suspended pouch nests. Everyone knows of the wonderful skill with which they weave into these structures all sorts of material in ways that would defy our ingenuity. When I was a boy my mother hung out some nice lace work from the window of our home, in the suburbs of Boston, to bleach and 


\section{CROW RELATIVES}

dry. A pair of orioles were building a nest in the elm close by and they appropriated the lace. We never knew what had become of it till in the autumn a great gale blew down the branch on which hung the orioles' nest, and there was the lace woven into it so skillfully that it took a long time to get it out, somewhat the worse for wear. But we like to hang out less expensive material, strings and yarn, and see the orioles tug at it and carry it off to their nests. A little girl up in our section of the country had a fine scheme. She prepared warp and woof for the orioles' use, and to each piece tied a label with her name and the date. The orioles made good use of it and were willing to give her their free advertising, for a number of fluttering tags hung from the nest announcing that the firm of "Helen Pease" had supplied building material.

The other species is the Orchard Oriole, a somewhat smaller bird, less brilliantly colored, and much rarer than the Baltimore. It is seldom seen further north than the latitude of southern New England. As its name implies, it is partial to orchards. There, in a pear or apple tree, often close to houses, it builds its nest, which is not so deep or elaborate as the Baltimore's, nor so pensile, and is made of dry grass.

On a certain farm one or two pairs of both kinds of orioles were accustomed to build. Both of them liked the pear trees for a nesting site, but the brilliant bird also used the elms and the other the apple trees. It is a hard matter, usually, to photograph any orioles' 


\section{CROW RELATIVES}

nest in situ. Many a nest hanging tantalizingly before me I have been unable to reach. But one year, on this farm, a pair of Orchard Orioles built their nest in the middle of a large apple tree, though among the topmost twigs, and it seemed as though here must be a chance for a picture, if ever I was to have one. After discussing the situation with Ned, we borrowed a tall ladder and set it up against the tree. Then I went up with camera and tripod to the top of the ladder and climbed into the slender boughs above. The only accessible side of the nest was shaded, so a short-timed exposure on the tripod was necessary. I managed to stick the spike of each tripod-leg into a slender branch or crotch, and, by keeping very still at the critical moments, fairly holding my breath, secured some good pictures. There were three well-grown young in the nest, and one picture shows an open bill projecting out, begging for food. After succeeding there, I placed two of the young on a branch in a more favorable position, and Ned and I both added pictures of young Orchard Orioles to our series.

All our other species which are classed in this group of birds have some claim to be called Blackbirds. Even the prattling Bobolink often gets the name of "Skunk Blackbird" because the male is black and white. This interesting bird is a regular "Jekyll and Hyde" in leading a double life. As Bobolinks they arrive in early May and settle down in the meadows and clover fields for about ten weeks of love, song and 


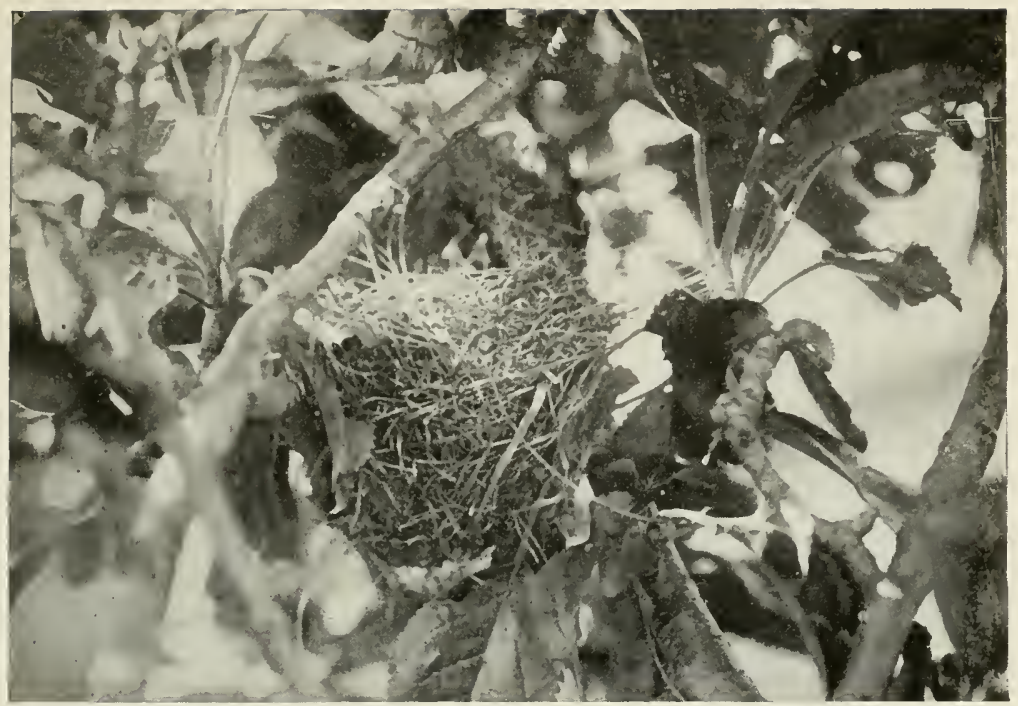

Nest of Orchard Oriole, with bill of young projecting (p. 150).

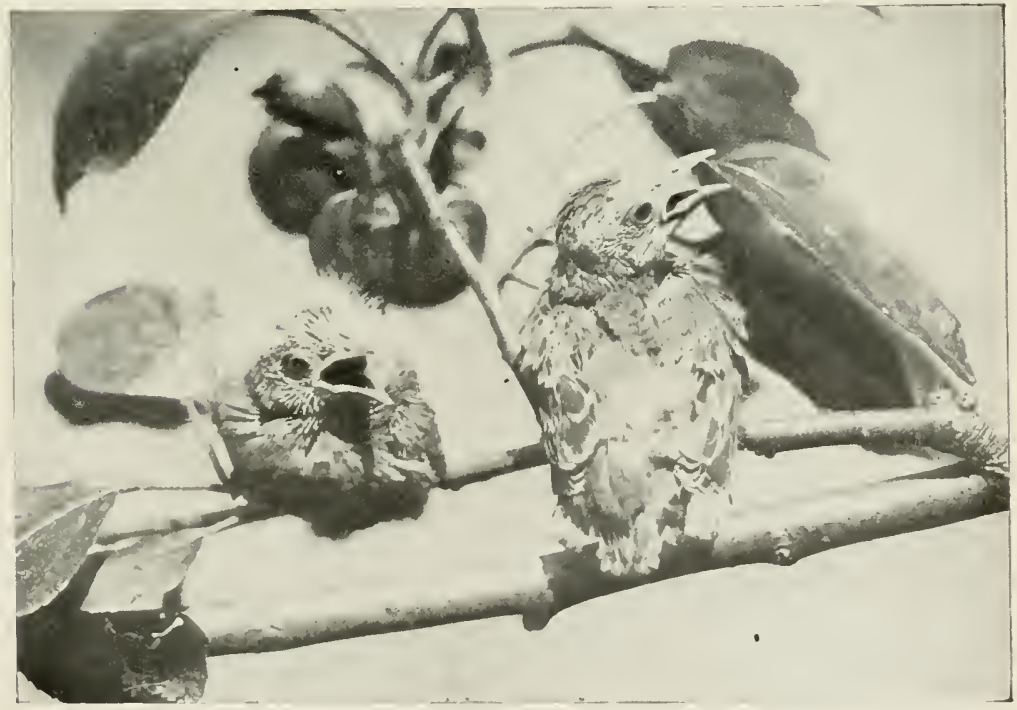

Young Orchard Orioles. "I'laced two . . . on a branch" (p. 150). 


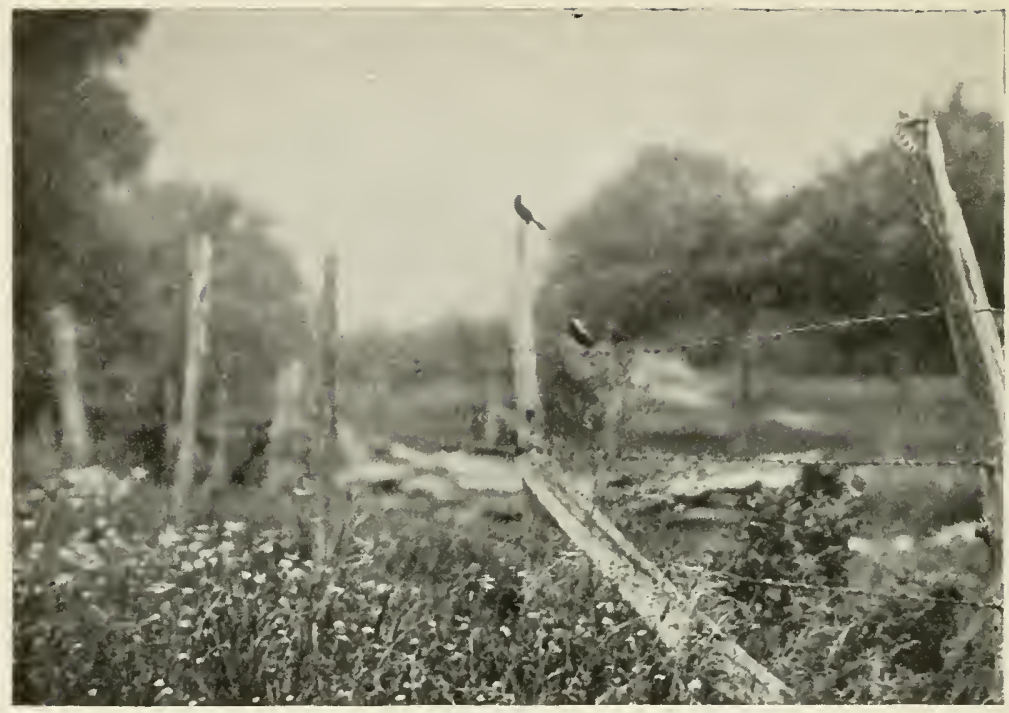

Male Bobolinks. "Settle down in the meadows" (p. 150).

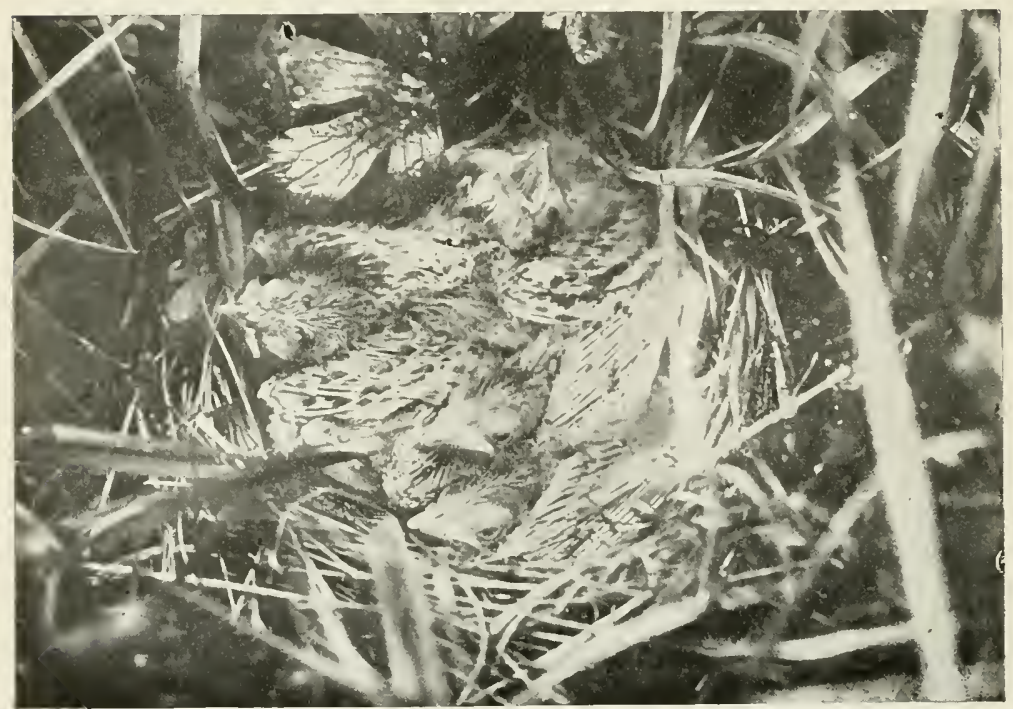

Five young Bobolinks in nest. "Found by dragging a rope" (p. 151). 


\section{CROW RELATIVES}

familiarity with men. But before July is out, presto, they are "Reedbirds," plain in dress, shy roamers in flocks, which levy toll upon the growing grain.

It is no easy task to find the Bobolinks' nest, hidden away snugly in the long grass. The garrulous male gives warning of our approach and the female sneaks from the nest, so that in vain do we try to flush her. But Ned and I have learned a trick or two. We get a rope a hundred feet or more in length, and in the evening or on a rainy day, having secured permission of the owner of the land, course systematically over the fields the distance of the length of the rope apart, dragging it between us and watching its progress. Suddenly up goes a brown bird, perhaps midway along the rope where it has just swished over the grass. Keeping our eyes on the spot where it started, we drop the rope and hurry there, and, on hands and knees, presently find the frail nest of dry grass with its five or six handsomely marked eggs, or an equal number of thriving young for which the meadow has produced abundance of insect or other foods.

Another of these quasi-blackbirds is that parasite, the enemy of the small birds, generally known as Cowbird, but it is also called Cow Bunting, or even Cow Blackbird. The latter name it deserves well enough, for the male is shiny black, all but its brown head and neck. The "cow" part of its various names it has earned by its fondness for the company of cattle. I have seen them on the backs of the cattle like big flies 


\section{CROW RELATIVES}

- especially out West where there are plenty of both cattle and Cowbirds. They are good friends to the cattle because they pull out grubs or maggots from the animals' hides or sores, and thus perform a useful service. We can only wish that they were as helpful to their nearer relatives among the birds. But the existence of every Cowbird proclaims the death of a brood of useful destroyers of insects or weed-seeds, which have perished because of the strong and greedy parasite. The female Cowbird lays one egg or more in the nests of these other birds, and in the struggle for existence the young Cowbird always wins. In other chapters where figure the victimized species, I shall show how the parasite works and fares.

The Red-winged or Swamp Blackbird is a familiar and abundant bird over most of the United States. Few fresh water marshes there are where we may not hear the "conk-a-ree" song or the harsh alarm note of this conspicuous bird. But common as it is, we must go where it lives in order to see it. A lady of my acquaintance thought that the Red-wings had decreased sadly in her vicinity; she had not seen one all that season. But that very day in walking to her home I had seen dozens of them in the meadows along the road.

They begin nesting by the middle of May, and the nests are easy enough to find if one cares to don the long rubber boots and go wading. The Red-wings, both the black male with his flashy scarlet epaulettes and his somber-hued streaky wife, will be hovering 


\section{CROW RELATIVES}

excitedly overhead or scolding from perches near by. There are so many pairs to the average boggy swamp that it is no hard matter to find nests, either built in the grass on top of tussocks, or suspended among reeds or rushes. It is said to be hard to photograph the female on the nest, but if one have a reflecting camera and wade near their homes, he is reasonably sure of good camera shooting, taking the birds both in flight and after they alight. They are a hardy species and now and then appear even in midwinter as far north as southern New England.

The Crow Blackbird is another common and widely known blackbird, though scientists have surrounded our old friend with some mystery by carving him up into Bronzed and Purple Grackle. If the specimen has the purple color of the neck and head extend down into the bronze color of the back, it is a Purple Grackle, but if the bronze is without purplish streaks, it is the Bronzed Grackle. One cannot, however, tell these races apart without shooting the birds, and for all but technical purpose the plain Crow Blackbird is good enough for most of us. With us it generally nests in gardens in towns, especially in evergreen trees, such as the Norway spruce. By the middle of May they have built their nests, which are much like those of the Robin, being lined with mud. There is quite a colony on the street where I live and every year the handsome birds are seen on our trees and lawns. Unfortunately they sometimes pull up sprouting corn, and this season 


\section{CROW RELATIVES}

in June some farmer whom they had annoyed put out poisoned grain in his field. The next day there were heaps of dead grackles under the trees where they nested and the young all starved. Not a single one was henceforth to be seen in the locality. It was a mean thing to do, for not only did it kill blackbirds, but probably various other more useful birds.

Out in the wilder parts of the country I have found the grackles nesting in hollow trees. In one instance, near my home, I found a nest in a swamp. I was hiding to photograph a Green Heron on its nest, and watched a male grackle spread his wings and tail and "squeak" his love song in a tree above me. Presently I noticed the female low down sneak along through the alder bushes and go on to a nest in the low fork of a very small one which grew out of water. This nest was built only about a foot above the surface-a most unusual location. Yet the grackles resort all the time to this swamp to feed, and I was not surprised that one pair were sensible enough to break away from old fogy custom and locate by their base of supplies.

The flocking of the grackles in August and early autumn is interesting. As I sit on my piazza I hear a rushing sound as of an approaching tempest, and with a chorus of harsh grating notes, a compact body of the black fellows almost darken the sky as they whirl past just over the treetops. Sometimes they alight and then our ears are regaled with a symphony as from a lot of unoiled axles of wheelbarrows. 


\section{CROW RELATIVES}

Our remaining species is the Rusty Blackbird. This is a little smaller than the last, about the size of the Redwings. The male is all black, which makes his white eyes conspicuous, while his mate is much less showy, of a dull rusty grayish brown. They are with us in April, on their way north, and then again rather late in the fall. None are known to nest further south than northern New England, but I have been at the Magdalen Islands in June when the young were just leaving their nests in the spruce swamps. These looked like Robins' nests and were built on the lower branches of the spruces. What a fuss the old birds made over my presence, not to lionize, but to berate! I took my revenge by setting up my camera near a small spruce and focussed on the top where the female Rusty was inclined to alight. The next time she did it I pulled the thread and caught her in the act, her open mouth emitting a flood of saucy expletives. 'This I shall use against her in court if the occasion ever requires it. 


\section{CHAPTER $\mathrm{X}$}

\section{A PUZZLE IN BIRDS}

(Finches, Sparrows, etc.)

MIIS family of bird species, called by naturalists Fringillidæ, or finch-like birds, comes the nearest to "flooring" Ned of anything in bird study. Not only is it the largest group among our North American birds, including about one-seventh of all our species, but many of these species look so much alike, especially as one usually sees them afield -skulking in grass or thick foliage, and shy in the bargain-that it is a very difficult matter to identify them. Try it, for instance, in the autumn, along the country road, where swarms of little brownish birds are constantly flitting on ahead of you and diving out of sight into the grass or bushes. They are sparrows, you say. Yes, but what kind? I can think of at least a dozen species which may be represented in that one flock. After studying them more or less all my life, I have to confess that very, very many times I am unable to identify these restless, nervous, timid, nondescript, elusive little rascals in the fleeting glimpse at them which they allow. I tell Ned not to get discouraged, 


\section{A PUZZLE IN BIRDS}

but just to do the best he can, and he will surely know a good deal about them, as, indeed, he already does. Not only are there sparrows, but grosbeaks, finches, buntings and various others. They are the great seed-eating group of birds, with strong cone-shaped bills, just adapted to splitting or crushing many kinds of seeds, or extracting them from various sorts of protecting covers. I was trying to think out some easy way to help Ned memorize and classify this difficult family, and I finally hit upon one which makes it very clear to him. Taking the species in the order in which they are ranked in the Handbooks, we may think of them in three groups. The main group is in the middle, the sparrows, or sparrow-like finchesbrownish-streaked birds, which mainly stay on or near the ground. Before these are put the hardy finches other than sparrows, which are found with us in winter, many of them coming from the far north-such as the Pine Grosbeak, Crossbills, Redpolls, Pine Siskin, Goldfinch, Snow Bunting, Purple Finch. After the sparrow group we find given the more southerly finches-the Chewink, Rose-breasted Grosbeak, Cardinal, Indigo-bird and several distinctly Southern species. This certainly simplifies the general plan and also helps one to remember the species, each of which it is then "up to" the bird student to learn. In telling of them in this chapter we will follow that order.

About twice in every decade, I should think, there 157 


\section{A PUZZLE IN BIRDS}

comes a winter when various birds from the far North visit us in good numbers, and notably the species in this first group of the finch family. Deep snow which covers up the tops of the weeds with their load of seeds, the failure of the spruces and other evergreens to bear cones, or both these events in conjunction, drive them south to us. When I was a boy, the winter of 1882-3 first introduced me to these Northern visitors. I was out after them at every possible opportunity and what an exciting time I did have!

As early as October the Pine Siskins arrived. They are closely related to the Goldfinch, but are easy to tell from them because they are streaked all over. I was out hunting partridge and woodcock, when, in an opening in the woods, I saw a very large flock of these birds, then new to me, alight on an isolated tree, fairly covering the branches. Trembling with excitement, I fired into the midst of them and am ashamed to tell now the number I killed. I have never seen so many together since, but have met them at various times, usually along roadsides, or in woods where there were birches or hemlocks. They seemed to be very fond of the birch buds. Years later, in northern Nova Scotia, I found them in June on their nesting grounds. In the shade trees along the streets of Pictou, I saw them and heard them singing prettily-Northern Canary Birds, one might call them, for they and the Goldfinch are closely related to the Canary.

In November the beautiful little Redpolls put in 158 


\section{A PUZZLE IN BIRDS}

their appearance and in flocks were wandering around the stubble fields, feeding on the seeds of the various weeds. At a distance they look much like the Pine Siskin, or even the Go!dfinch in winter plumage. But, a closer view shows a pretty crimson patch on top of the head, and now and then there is one, an adult male, with a crimson wash over the breast. I remember that I took a very great fancy to them and all that winter I loved to watch the Redpolls. They are hardy birds, breeding in Greenland and the lands nearest the North Pole.

But I was equally fond of the grosbeaks and crossbills. The occasion when I first saw these species stands out in my memory among the great events of my life. I was walking home one afternoon that same bird-eventful winter, in December, along a street in Jamaica Plain, a suburb of Boston, when I saw a flock of a dozen birds, the size of Robins, eating the buds of a maple tree in a garden, just over the sidewalk. Hurrying on toward them, I saw that they were dark gray in color, with yellow on the heads and backs, except two, which were of a beautiful rosy hue. They were Pine Grosbeaks, the rosy ones being adult males. Though it seems that, on the whole, I never enjoyed life more than I do now, at the same time I realize that familiarity has probably made me incapable of ever experiencing again the intense, overpowering excitement and delight which I experienced in that first sight of the Pine Grosbeak, hardy denizen of the North, 


\section{A PUZZLE IN BIRDS}

whose very presence pictured before my inflamed imag. ination the boreal solitudes in their silent, icy grandeur, as did just once the rare Evening Grosbeak.

And the crossbills! I was out sleigh riding in Brookline and was driving on a road that led through a wooded estate, when I noticed a group of birds on a limb of a pine tree which extended out low over the road. I stopped the horse almost under the strange birds. Some were dull red or pink, some greenish, and a few of each sort had white bars on their wings. They were a mixed flock of White-winged and Red Crossbills, birds the points of whose upper and lower mandibles of the bill cross one another. It would appear, with this seemingly awkward arrangement, as though they could not eat; yet here they were skillfully extracting the seeds from the pine cones, their favorite diet. For five minutes or so I fairly devoured those rare birds with my eager eyes.

The rest of that winter I revelled in the Northern birds, but it was not till several years afterward that I saw any more, so irregular are their occurrences. However, they did reach us occasionally, and some years I held tryst with the crossbills and siskins in summer up in their Northern homes in the Maritime Provinces of Canada. One season they stayed with us very late. Pine Siskins visited the larch trees in my garden in May, and on the seventh of May I was amazed, while looking for birds in a pine grove, to have a flock of White-winged Crossbills fly up from the ground and 160 


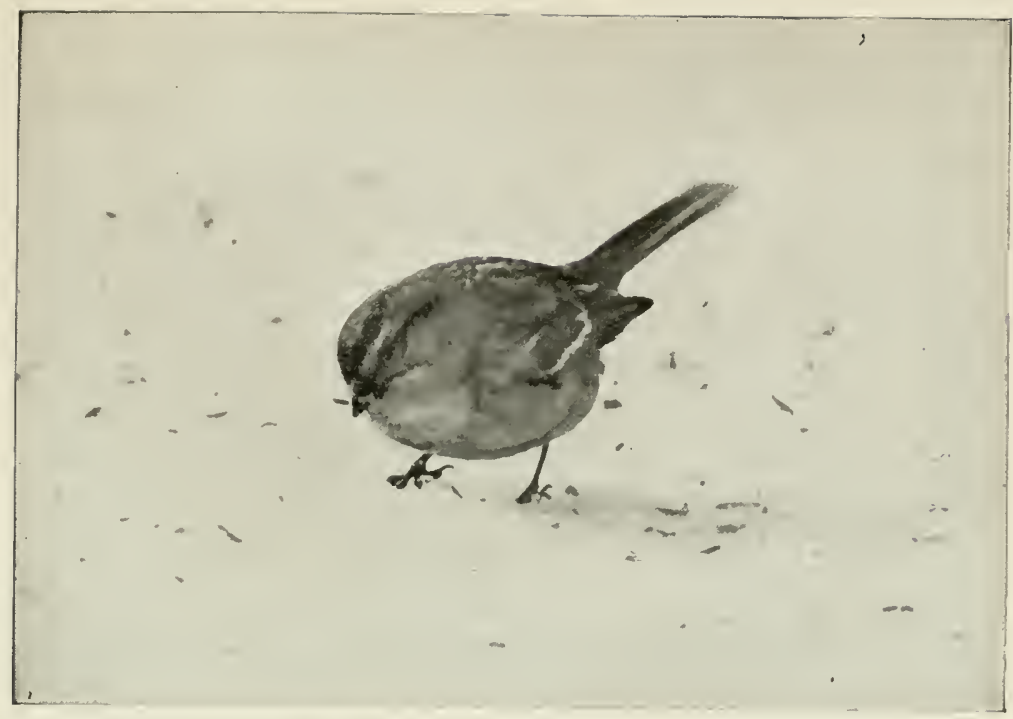

Tree Sparrow eating hay seed thrown on the snow. "The happy little fellow" (p. 165).

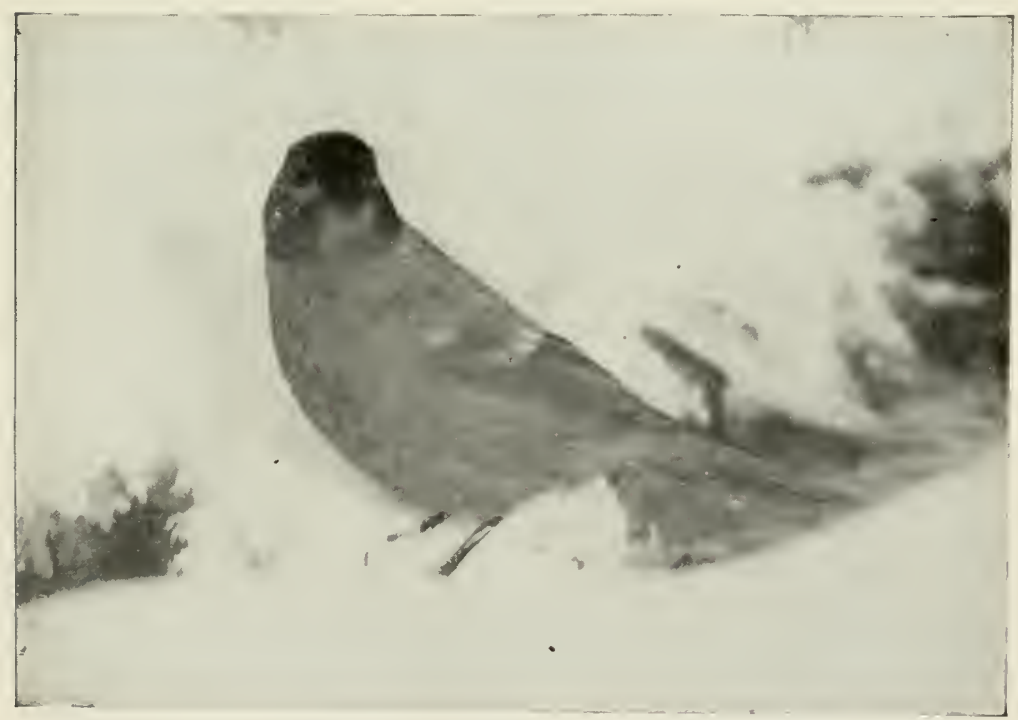

Pine Grosbeak about to drink. "Our . . constant visitors" (p. 161). 


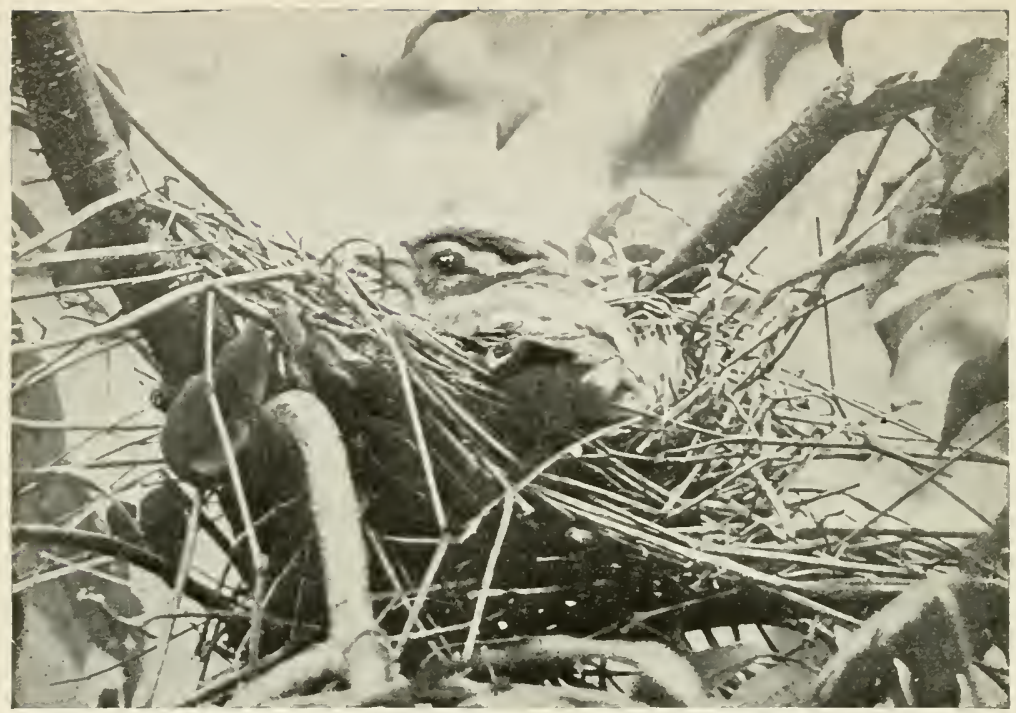

Female liose-breasted Grosbeak incubating. "Let me work on her within a yard" (p. 174).

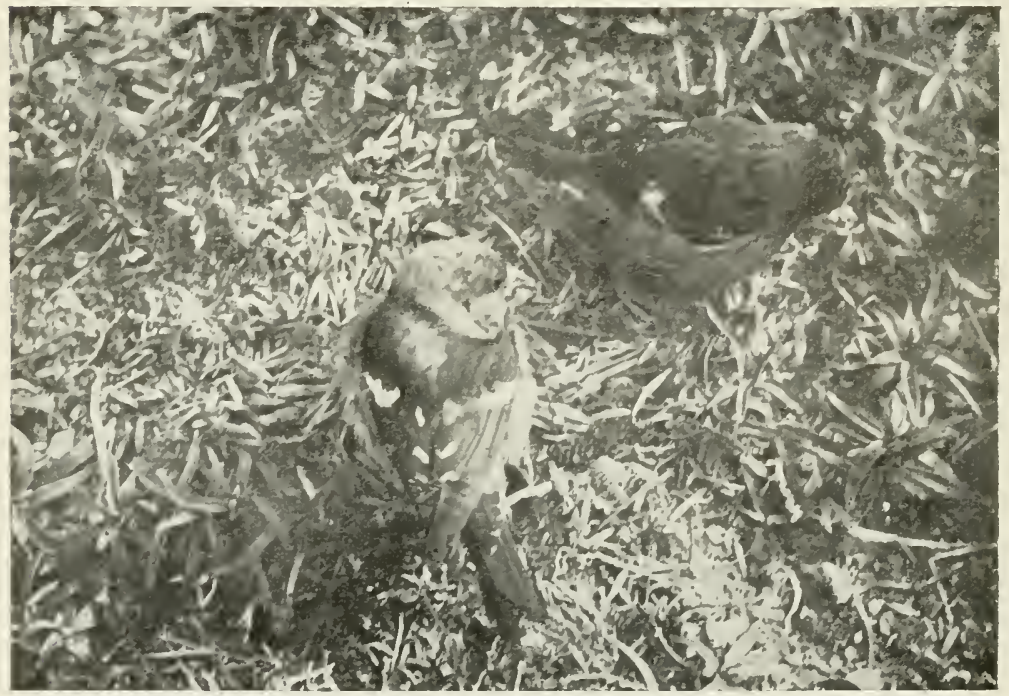

I'air of White-winged Crossbills. "Eating oats like little horses" (p. 161). 


\section{A PUZZLE IN BIRDS}

then stand and look at me from the lowest branches of the pines. Usually all these Northern birds have disappeared by the last of March or first of April.

In the winter of 1899-1900 both the crossbills were abundant, especially the usually rarer White-winged bird. It was a beautiful sight to see a flock of them almost daily on my lawn, picking up maple seed or other food. They were fairly tame, yet never so much so as a pair of White-wings that I found on the top of Bird Rock, far out at sea, in the Gulf of St. Lawrence. These were so tame that I actually caught them as they fed on some oats which I put out on the grass for them. They were very much emaciated, so I put them in a cage to have a good meal, but there they acted so frightened that we let them go and they returned at once to the oats. While they munched away at a pile of these, like little horses, I set up a camera on the tripod within two feet of them and photographed them without alarming them in the least.

Early one morning in January, 1907, Ned came rushing in to inform me that a flock of Pine Grosbeaks were right by the doorstep. Sure enough, there were half a dozen of them, feeding in the path where the heavy snowfall had been shovelled off. They seemed to be picking up little sticks and biting off the ends, but I soon found that these were the winged seeds of our ash and maple trees, from which they were extracting: the kernels. From that time on till the middle of March, they were our almost constant visitors. They 


\section{A PUZZLE IN BIRDS}

were so tame that it was quite easy to photograph them with the reflecting camera. I met one little boy in town carrying around a paper bag of salt, trying to catch grosbeaks by putting salt on their tails, which he had been told was the proper method! Yet for all their familiarity they were timid in a way, for at any sudden noise, as of a wagon or a train, the flock would unitedly spring up with a twitter and a whir of wings and dart off, not to return for an hour or two. Sometimes there would be three dozen grosbeaks on our lawn at the same time, mostly gray birds, though once I saw seven rosy males.

When they finally disappeared it really seemed lonely without their intimate companionship, but kind Nature provided a most appropriate substitute in an equally large flock of Purple Finches, which stayed with us from late March pretty well through April. The carmine-hued males were, in this case, about equal in number to the somber females. After a time the flocks, which I often met in the woods as well as gardens, broke up into pairs, and presently they were nesting in scattered cedars or other evergreens in pastures or gardens. They are quite hardy birds and are sometimes found as far north as New England in the dead of winter, though they are not as northerly as the species we have been describing.

With them we may well associate the beautiful Goldfinch, sometimes, but improperly, called the Wild Canary. They are interesting birds, original in their 162 


\section{A PUZZLE IN BIRDS}

ways and no slaves to fashion. The male in summer, with his resplendent yellow and black plunage, is gay cnough, yet he lays all this grandeur aside for the winter and goes garbed like his plainer wife. Hardy birds, they often flock about us through our coldest winters, and well might they be, we should think, among our earliest breeders. Yet they spend the spring and summer in play and at the last possible moment, as though it was a stupid task from which they shrank, they finally set to work to build nests and rear babies. The eggs are usually laid in a soft, dainty nest on a bush or sapling in a swamp or by the roadside in late July or early August. The young are not awing till well along in August and it is often pitiful, when September frosts come, to find the callow fledglings in the garden, barely able to flutter from their nest, chilled and piping plaintively. Ned called my attention to some in this predicament on a very cold day, the fifteenth of September. That same year I photographed a brood of them in a willow thicket beside the railroad track about the twentieth of August, and I tried hard to snap the parents feeding them, but when the camera was near the nest they would not approach, no matter how long I waited.

It would be a great omission not to speak of the Snow Bunting, that hardy boreal bird which has well earned also the name Snowflake, from the whiteness of its plumage. I have seen them by hundreds on the wintry seacoast, on beach, marsh or sand dunes. I wish 


\section{A PUZZLE IN BIRDS}

they were as common inland where I now live, yet they are there no strangers to Ned and me, whirring over the snow and the projecting stubble in open places. One very wintry day they afforded us a beautiful spectacle. We were out sleigh riding, on a road which followed the open summit of quite a high hill. A snow squall came up, driving fiercely in our faces. Presently we saw what at first I thought was a cloud of the light, newly fallen snow stirred up by a squall of wind, blowing toward us across a weedy field. Instead it proved to be a large flock of Snow Buntings. Their advance guard were alighting to eat the seeds of the weeds, while those in the rear were continually flying over those ahead of them and themselves becoming leaders. Thus the flock rolled over and over as it were, like a great white wheel, ever advancing.

Associating with the Snow Bunting we are liable occasionally to meet the Lapland Longspur, a bird of about the same size, but darker colored, the males black on the breast and throat. They are much rarer than the other, enough so to make it a red-letter day when one is identified. How delighted I was when I saw my first Lapland Longspur! I was driving in a sleigh in February, along a country road, when I saw three birds ahead of me feeding in the road. Two were clearly Snow Buntings, as their white wings showed. The other was unfamiliar. I drove up within a few feet of them and stopped. The stranger had buffy cheeks and some black on the breast. It was 164 


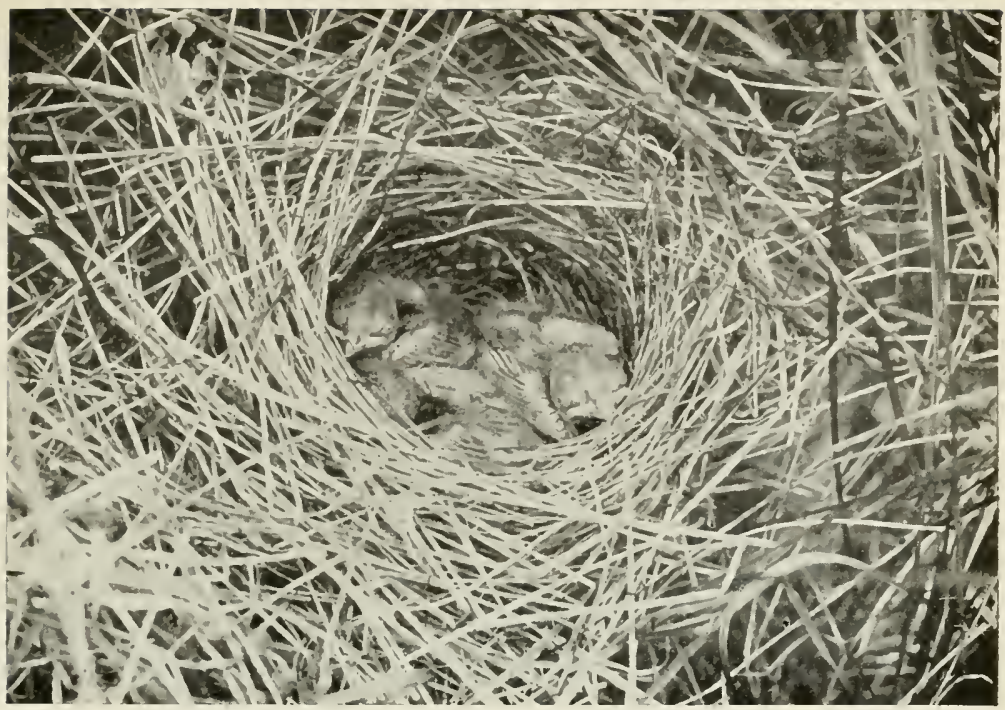

Young Field Sparrows in nest. "On the ground" (p. 169).

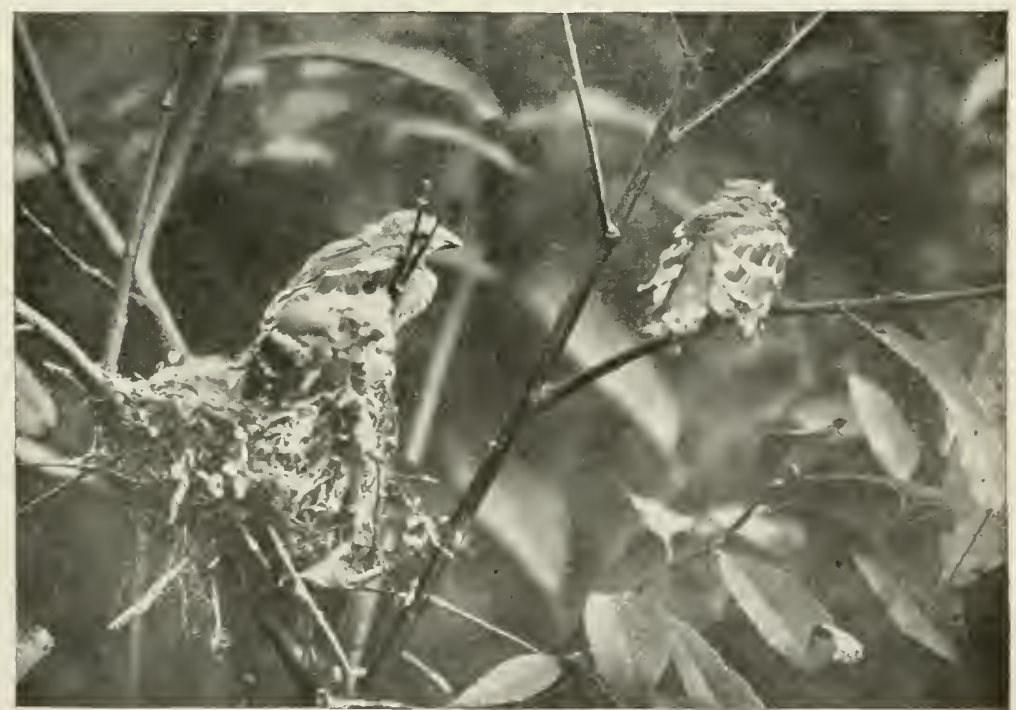

loung Goldfinches, ready to leave nest. "In a willow thicket" (p. 163). 

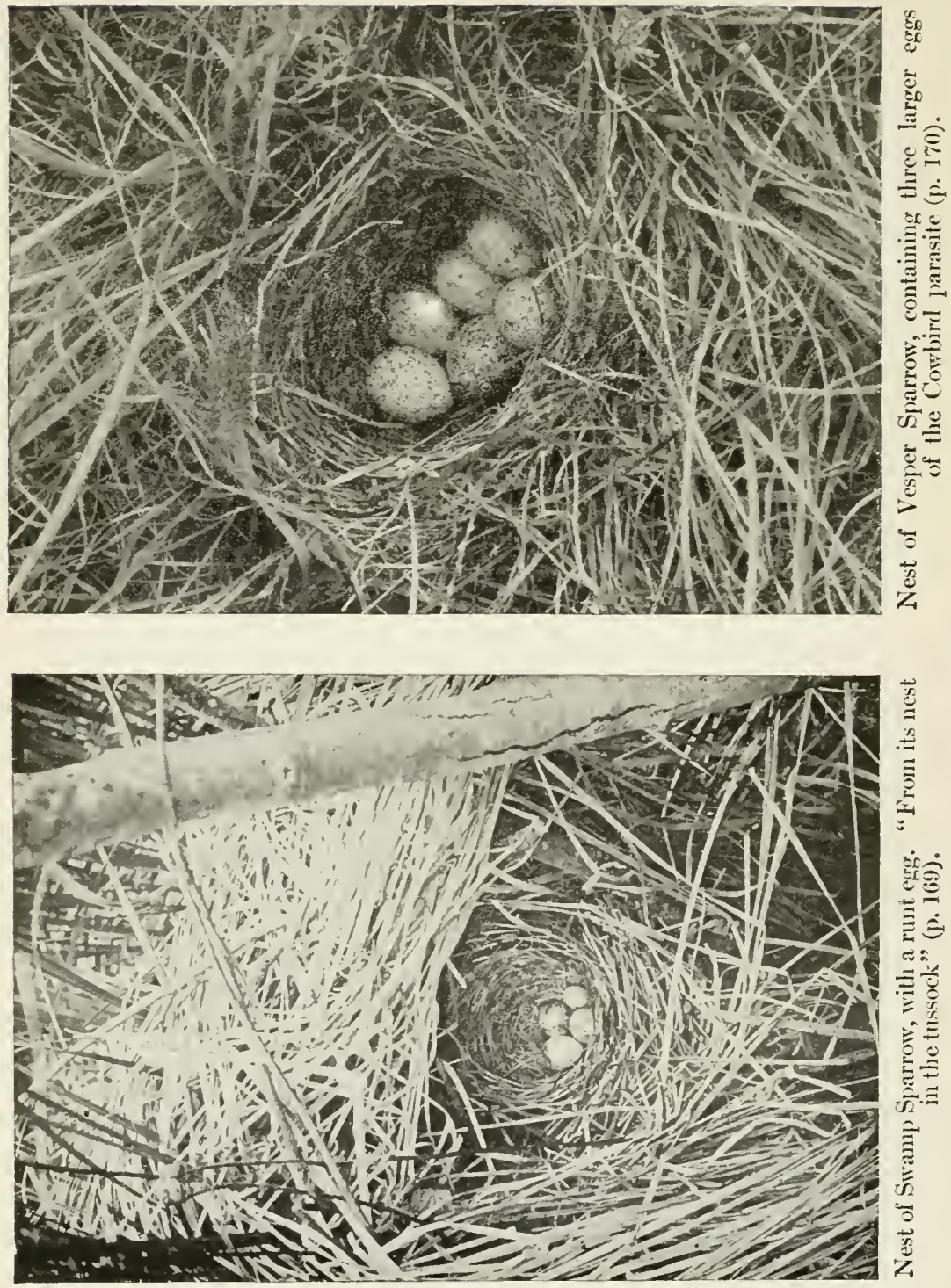


\section{A PUZZLE IN BIRDS}

not a Horned Lark and I instantly recognized the Lapland Longspur, for which I had so long looked in vain.

And now for the Sparrows. The Tree Sparrow, or Arctic Chippy and the slate-colored Junco, or Snowbird, are the only native sparrows which are common in winter. We do not count that foreign pest, the English Sparrow, which does not deserve to be considered as a bird, but rather as a feathered rat, a pestiferous mongoose to destroy bird life and drive out our beloved native birds. The pretty little warbled song which comes from the weedy patch or the line of shrubs or stubble along the fence on a bitter cold February morning is the good cheer of the happy little fellow from the far north, the Tree Sparrow, and it is almost the only real song that we are likely to hear at this season, though the Chickadee has some pleasant notes, and the Junco will begin in March to practice its simple trill. The Tree Sparrows are a bit timid, but I have had them come up on the window-sill to be fed and photographed. Ordinarily, though, they will not venture quite so much, but we can scatter hayseed or small grain on the frozen snow in the garden and they will greatly appreciate it. Associated with them we shall often see the Junco, which is even shier.

A few of that commonest of our sparrows, the Song Sparrow, linger in sheltered places through the long cold winter, and the whole tribe of them are back in March. Early in the month we first hear their familiar and beautiful song ringing out from the shrubbery 


\section{A PUZZLE IN BIRDS}

along the roadsides, or in the garden. One can distinguish them by their heavily marked breast with a conspicuous brown spot in the middle.

Soon after the middle of March we are likely to notice on the edge of the woods, or along retired wooded roads, a bird of deep rich brown color. It is the Fox Sparrow, the largest and handsomest of the sparrows. It is fond of scratching among the dead leaves, and is a great musician, though, unfortunately, it seldom sings until it approaches its Northern breeding grounds, for it never remains with us. I have twice found its large, well-built nest on the Magdalen Islands and have heard there many a time its wonderful song.

Probably the next to arrive will be the Swamp Sparrow, late in March. It frequents bushy swamps or meadows interspersed with brush, and, though it resembles the Song Sparrow, can be readily distinguished from it by its reddish head and unmarked ashy breast. The song is a loud, simple trill, not unlike that of the Junco. 'The rare Lincoln's Sparrow, related closely to this and the Song Sparrow, is also possible reward for careful scrutiny.

Late in March or early in April comes the Field Sparrow, and about the middle of April the nearly related Chipping Sparrow. These and the Tree Sparrow are a good deal alike-slender, long-tailed littls fellows, with brownish-red crowns. The best way to distinguish them is that the Tree Sparrow has a conspicuous dark spot on the middle of the breast, the 


\section{A PUZZLE IN BIRDS}

Field Sparrow a plain breast and reddish bill, the Chippy a distinct white stripe over each eye and a gray rump, with the whitest breast of them all.

About the same time as the Field Sparrow, or soon after it, comes the Vesper Sparrow, or Grass Finch, with its simple but pretty song. This is the species with the bay-colored patch on the bend of the wing and the white outer tail feathers. This last is especially characteristic of the Junco, but one cannot confuse that slate-colored bird with the brownish Vesper, and at any rate the former disappears on its northward migration soon after the other begins to arrive.

Somewhat similar in haunts and habits is the Savanna Sparrow, which also arrives in early April. They are found in dry open fields, but also in meadows or salt marshes. They have streaked breasts, like the Song Sparrow, but are smaller birds. In most inland localities they are not common, but in many seacoast regions, and notably along the Northern coast, any sparrow which one may see is more than likely to be a Savanna. They haunt the grassy wind-swept headlands or even the sand dunes.

On the coast we also may meet the Sharp-tailed and Seaside Sparrows on the salt marshes, skulking in the long grass, and in late fall and winter the rather rare Ipswich Sparrow. I have found a number of the latter in dry open places not far back from the sea, or on islands.

But we have not yet exhausted the possibilities of the 167 


\section{A PUZZLE IN BIRDS}

migration inland. There is a very queer little fellow called the Grasshopper Sparrow, so named because its funny weak little song sounds more like this insect's attempt than a bird's. It is a small bird, dull-colored, with plain ashy-colored under-parts and is very secretive, one of the hardest of birds to locate and observe. It frequents dry fields, but might be common all about one without its presence being detected, unless one noticed the faint, locust-like song. A somewhat similar bird, but rarer, is the Henslow's Sparrow, which, however, prefers moist grass land, notably springy hillsides where the bush known as shrubby cinquefoil abounds.

Last of all, in May, come those beautiful sparrow migrants, the White-throated and White-crowned Sparrows, both of which nest well to the north. The latter is rather rare, more's the pity, for it is a very striking bird, with its conspicuously white crown-patch. It is only once in a great while that I am able to see one. The White-throat is much better known. The male has a pronounced white bar on each side of the head, and sometimes may be mistaken for the other. But when one really meets the White-crown, he will know it. "Pee, pee, peabody, peabody," sings the Whitethroat in long-drawn, high-pitched piping, and thus gains the name of Peabody-bird. The male sings his peabody song vociferously in Maine and Canada, but I have heard it all too scldom further south.

There, now, we have gone through with every one of our numerous Sparrows which we are at all likely to 168 


\section{A PUZZLE IN BIRDS}

meet. Do you suppose now you can go out and identify them? Remember there are the confusing plumages of the young, which help to make the muddle all the worse. No, you must study hard on them, be patient, and get to know them one at a time. With a little intelligent care, and referring to the descriptive books, you will be surprised how quickly the common birds can be tolerably well learned. So there is no need of being discouraged. If we could learn everything easily at once, there would be far less fun in studying birds. We need some difficulties to arouse the spirit of true sport.

When it comes nesting time the nests of most of the sparrows are to be sought and found on the ground, and usually in grass. The Chippy, however, builds in a tree or bush near the house, though once I found its nest on the ground in an orchard. The Song Sparrow sometimes gets lofty ideas and builds in a bush even as high as one's head, but the vast majority of nests are on the ground in grass or beside a bush. This is the nest with four or five darkly blotched eggs which one so often finds in the pasture or by the roadside by almost stepping on it and having the sitting bird pop off at one's very feet.

In wading the meadow, I expect to start the Swamp Sparrow from its nest in the tussock. The Field Sparrow likes the clump of weeds in pasture or orchard for the temporary home, and it will be either on the ground or within a foot of it among the stems of the weeds or 


\section{A PUZZLE IN BIRDS}

in a tiny sprout. The eggs are smaller and more finely marked than those of the Song Sparrow, and thus can be distinguished.

It is not so easy to find the Vesper Sparrow's nest, though it is built usually where the grass is scant, for the bird sees an intruder and usually flies off before he comes dangerously near.

The Savanna Sparrow, though it often builds in similar situations, is more tame and less shrewd, and I have found their nests by dozens through flushing them, in regions where they are common, as on open headlands by the sea. But the Grasshopper Sparrow - how it can hide its treasures! I have found but one of their nests and it was on this wise. I was crossing a dry, sandy field, with very sparse grass, when out fluttered a small sparrow right from my very feet. Of course I knew there was a nest, though none was in sight. Down I dropped on hands and knees, laying my handkerchief on the grass about where the bird was first seen. I felt like a fool when, after a quarter of an hour spent in examining every inch of ground, I could not for the life of me find the nest. The only thing to do was to withdraw, mark the spot and try again. So in half an hour I came back and this time I saw exactly where the bird flushed. But even then it was a couple of minutes before I detected the tiny tunnel, overhung by dry grass which led in under a small tussock. There, clear out of sight, was the simple nest of grass with its five white, sparsely marked, 


\section{A PUZZLE IN BIRDS}

handsome eggs, very different from those of our other sparrows.

Sparrow's eggrs are usually so much alike that in most cases it is necessary to identify them by clearly seeing their owners, and often this is a very difficult task. I have spent hours waiting or searching about, trying to make the secretive, skulking bird show herself. Even if the pesky thing does come out for an instant, it is more than likely that it will be gone again before the glass can be brought to bear.

Almost everyone who lives in the country has the pleasure of seeing the familiar Chippy nest on the premises, in perfect confidence of good treatment. Chippy nests in my orchard, on any bush or low tree in the garden, or even on my piazza porch in the woodbine. There I took her picture while she gazed at me beseechingly, hoping that I had not now become her foe. 'This last spring a pair built their nest on the trellis right at the entrance of our front door, but there was so much passing that the little bird became frightened and the eggs were not laid there.

Chippy is a good subject to photograph in the act of feeding her young. Some sparrows are too shy and nervous to brave the camera, but she will do it. A pair had a nest in our mulberry tree, and on the day that the four little fellows left the nest I caught two of them and made them sit on a stick in front of the camera which was all ready for business. At first mother Chippy was a little afraid, but she soon plucked 


\section{A PUZZLE IN BIRDS}

up courage and at frequent intervals came with an insect and fed the little fellows in turn. In a short time I had a dozen as good feeding pictures as I could want.

Leaving the Sparrows, now, to be studied afield, I must tell a little about that other group of birds in this finch family which we referred to at the beginning of the chapter as the more southerly fellows which are large of beak. 'The next one after the sparrows, as numbered in the American Ornithologists' Union Check List, is the handsome and common bird variously known as Towhee or Chewink, and I have also heard it called Swamp Robin. This is the black and white fellow, with brown markings, who plays hide and seek with us in the bushy pasture, the scrub land, or along the roadside. He is bound to see who you are, but does not intend that you shall see him very much, though he calls out a pert inquiring "tow-hee," or "chewink," as he seems to different observers to say. But when he thinks there is no one around to bother him, he stands up proudly on the top of a bare tree that towers above the thicke' of scrub and sings a happy and more pretentious song. The nest is hidden away in a brush heap or under a small buch and about the only way I know of finding it is to flush from it the brownish female, who will soon return with her blackgowned husband and set up a great outcry. Once I was shown a nest out in the open in the hollow of a grassy bank in a pasture. The female was in charge 172 


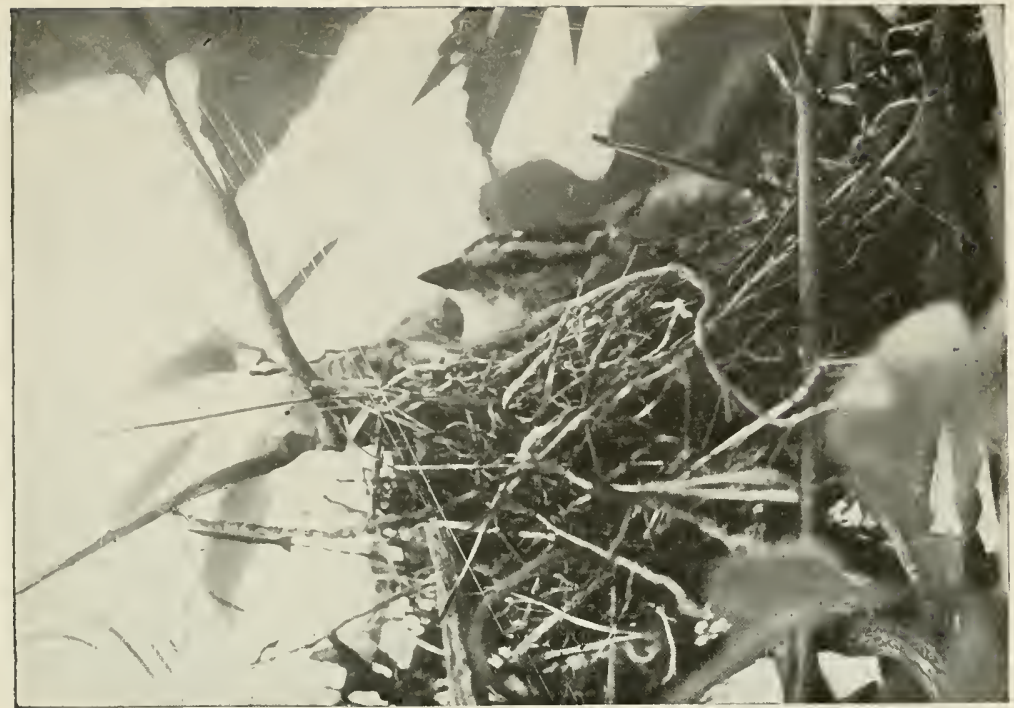

Nest of Chippy. "On my porch in the woodbine" (p. 171).

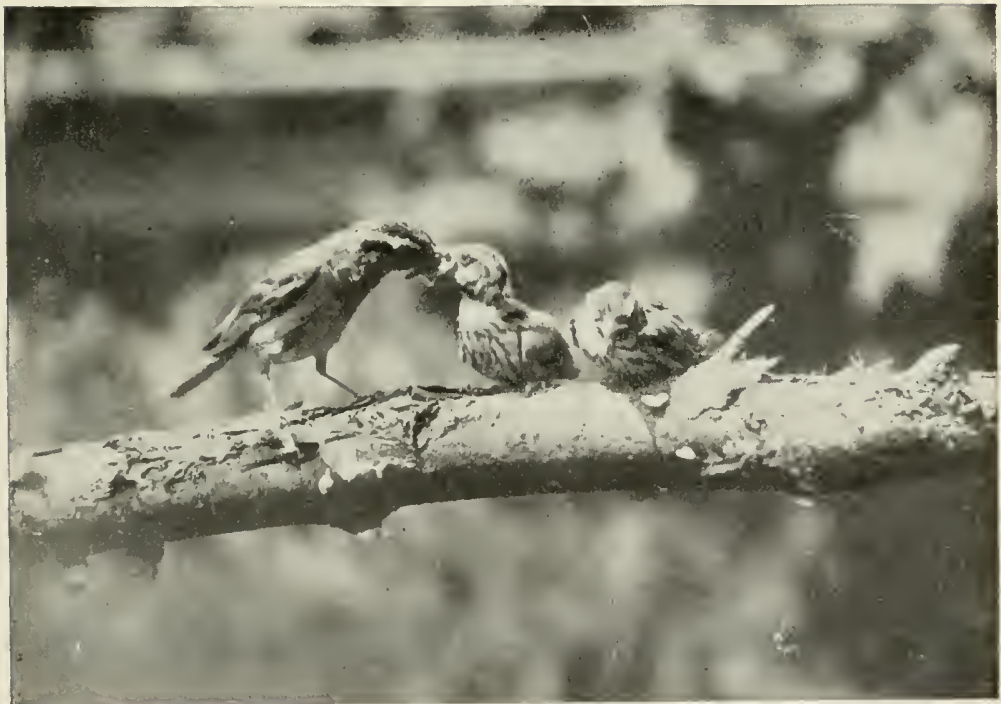

Chipping Sparrows. "Yed the little fellows in turn" (p. 172). 


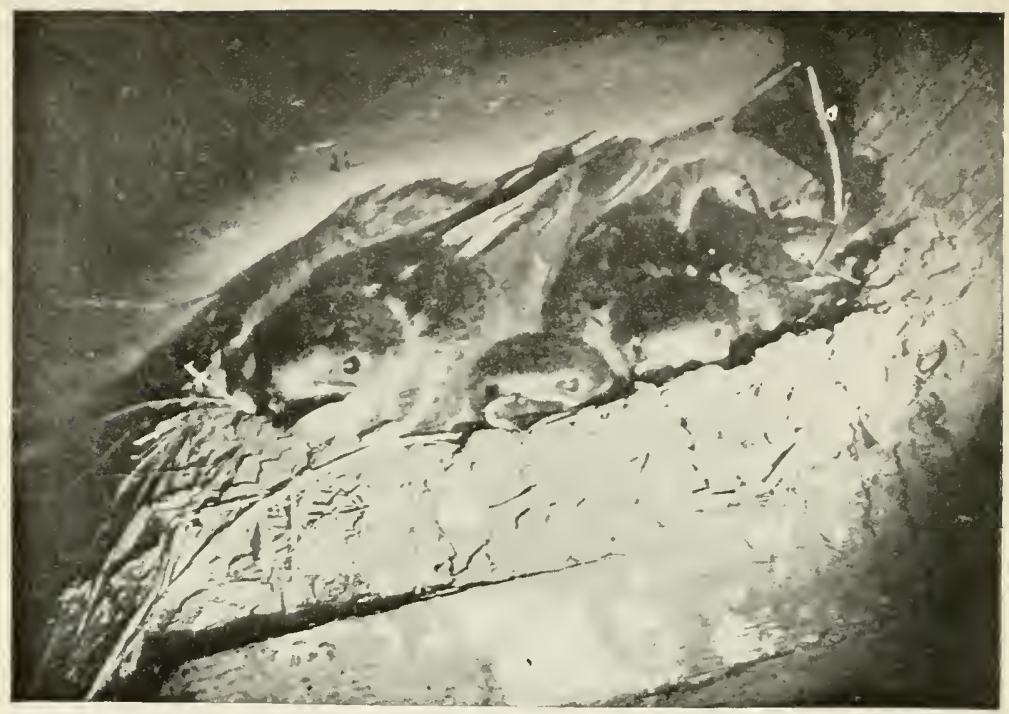

Young Barn Swallows. "Threw light down into the nest" (p. 180).

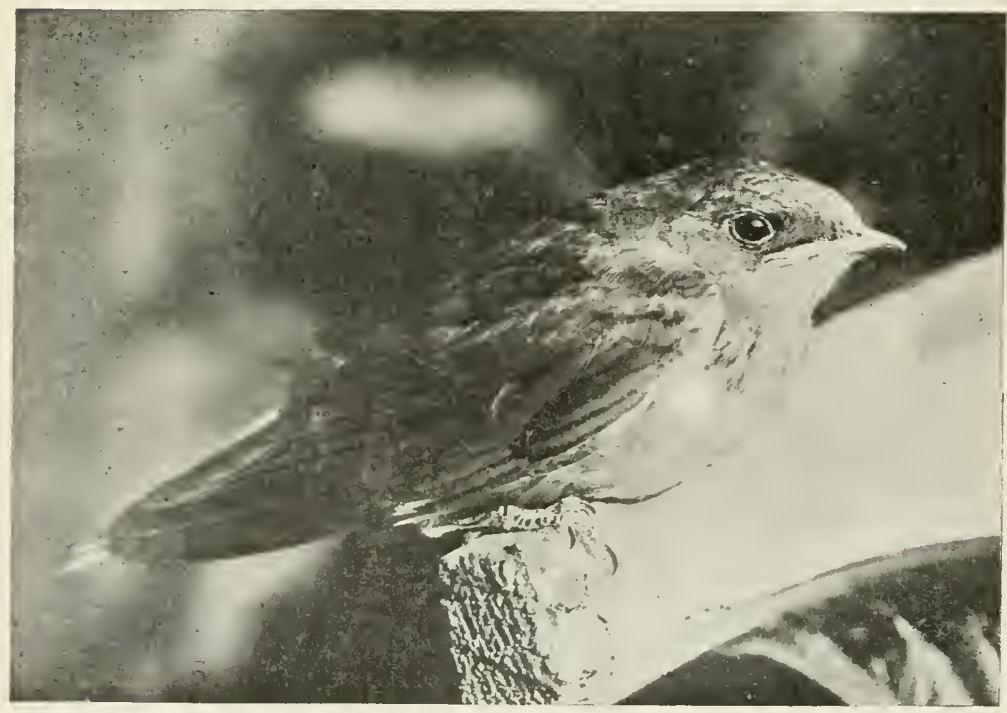

Young Barn Swallow. "Brought down a young Swallow" (p. 180). 


\section{A PUZZLE IN BIRDS}

of the five pretty eggs and allowed me to come quite near, but she crouched down so deep into the hollow that a picture showed nothing but her bill.

Then there is the Rose-breasted Grosbeak. The male is a beautiful black and white bird with a rosecolored spot on his breast and under each wing, and is a sweet singer, with clear, liquid notes. But the female is a plain brownish little lady, looking like an enlarged sparrow. They are moderately common in many localities, and it would be well if they were more so, for they have a habit which will commend them to all who know of it. If they are seen in the garden, do not assume that they are working mischief; though sometimes they eat buds, they are mostly insectivorous and are among the few birds that will eat potato bugs. I have known them to go day after day to the potato patch to feed upon these vermin as long as they lasted. I tell Ned that they are more useful in that line than he, for he is not fond of "picking potato bugs," though his mother tells that when he was a baby she found him one day munching a horrid black squash bug. But in time he proved not to be insectivorous after all!

This grosbeak builds a frail nest of small sticks and rootlets in a low tree or bush in a swamp or thicket, usually from five to ten feet from the ground. Both birds incubate and they are not very shy, only the nest is rather hard, usually, to get at to photograph, unless one raise the camera on stilts and focus, say, from a step-ladder. In one case a nest was out on a horizontal 


\section{A PUZZLE IN BIRDS}

bough and $I$ bent it down and tied it so that the nest was on a level with my camera on the fully extended tripod. When I came, sometimes the male was on, but more often the female. He would not let me walk up with the camera, but she allowed me to do so and even to work on her within a yard, if I moved slowly and kept very quiet.

Still another interesting and striking species is the Indigo-bird, or Indigo Bunting. It is a small species, of sparrow size, the male of which is of a rich dark blue color all over, very gaudy and conspicuous. One would not suppose that the dull brownish female could be any near relative of his. They are fond of bushy pastures and the neat nest is suspended in a thicket or brier patch. One that I found was beautifully lined with black horse-hair. Another was discovered through the anxiety of the male that I should not find it. I was passing through some scrub and brier thicket one hot day in June, looking for nests to photograph. Suddenly this male Indigo-bird appeared on a poplar tree near by and began to advise me in his language that the best thing I could do was to get right straight out. Instead of doing this, I began to look about all the more sharply and soon I found his nest, nearly completed, close to where I had just passed. Later it held three bluish-white eggs. I photographed them, but could not catch either of the birds with the lens, though I hid the camera quite well in a clump of bushes near by, covering it with foliage. 


\section{A PUZZLE IN BIRDS}

In the Middle States, up as far as New York City, we may see the brilliantly colored male Cardinal Grosbeak and his more somber-clad mate. Their beautiful songs are a delight about the garden, and their nest may be found in the adjoining shrubbery. The further south we go the more plenty they become. During my trips to the South I have greatly enjoyed the Cardinal.

Besides the Cardinal, there are other distinctly Southern species in this family of which it is beyond my present purpose to write. But instead, seeing that I mentioned above the American Ornithologists' Union, and also the difficulty of studying such birds as this finch family, I want to advise every one of my birdloving readers to become an associate member of this organization, if he or she has not already done so. Though it is the greatest ornithological society of America, and includes in its membership the leading scientists, it is intended just as much for beginners in bird study, to increase and cultivate the friendly interest in birds which has now become so widespread. Its "Associate" class of members numbers many hundreds, all over the United States and Canada, including boys and girls, and ladies as well as men. My young friend Ned is an enthusiastic "Associate," and it helps him very much. Through it he knows many other birdlovers. Its large quarterly magazine, The Auk, the leading bird publication in America, which everyone belonging to it receives, is very instructive and enables 


\section{A PUZZLE IN BIRDS}

him to keep up with whatever is being done by other students. Now and then he goes to its "Annual Congress," which is a most delightful social occasion. There he gets acquainted with many other young ornithologists, and also with the great scientists, who are glad to see all who are beginning to take interest in birds, no matter how little they know about the subject at present. It costs three dollars a year as membership fee, which includes subscription for The $.4 u k$, and I hope that many young bird lovers, or others, after reading this will write to the Treasurer of the A. O. U., Dr. Jonathan Dwight, 134 West 71 st Street, New York City. He will send you any desired information. The more membership fees the Union has, the better magazine they can publish, with more illustrations, and the more they can do for bird study and bird protection.

If you could only have a talk with Ned, I am sure he would soon persuade you to join and make you feel that because you love birds you are just exactly the kind of a person that they want on the roll of membership.

Both he and I want also to say a good word for the Audubon Society, whose special work is to interest in birds those who have not thought much about them, to train the growing generation of children and youth to love and befriend the birds, and to secure money, laws and public sentiment for their protection. In each State there is a local Audubon Society, all of which 


\section{A PUZZLE IN BIRDS}

are incorporated as "The National Association of Audubon Societies." For a few cents annually anyone can be a nember, and for a dollar a year more have that delightful little illustrated magazine, BirdLore, the organ of the Association, which every beginner in bird study ought to have and all bird lovers as well. To secure further funds for the educational and humanitarian crusade, for enforcement of protective laws, for guarding breeding-colonies of birds and the like, there are various degrees of honorary membership, attainable through certain money payments. Inquiries addressed to the headquarters of the Association, the office of its President, Mr. Wiiliam Dutcher, 141 Broadway, New York City, will secure all information needed. Those who take delight in our wild birds and are interested in their protection will both get and give a great deal by being associated in these organized ways with other bird lovers, and "the sport of bird study" will thus be found far more fascinating than by "going it alone." 


\section{CHAPTER II}

OUR PRICELESS SWALLOWS AND SWIFTS

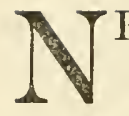

ED came into my study one summer day, when l was trying to write a bird article, just as I made a slap at a tormenting housefly and almost upset my inkstand. "Your intention was good," he remarked, "but you aren't as graceful as the swallows yet in your fly-killing. But how did so many flies get in here?" "Oh, someone left the screen door open," I replied; "that is one reason, and, since you have mentioned swallows, you remind me of another, and that is that we haven't swallows enough to catch all these flies. If they were as common as they used to be, I don't think there would be so many flies to bother us." "Did they use to be very plenty?" inquired Ned. "Yes," I said, "according to all accounts the familiar kinds were quite abundant up to about twenty years ago, when the hateful English Sparrow drove them away by fighting them or taking their nests. I remember well when I was small what lots of swallows there were around Boston, where I lived, far more than there are now. Of course I don't mean to say that there weren't any flies then, but there was a big colony of Barn and Eave Swallows on our next door neighbor's barn, and 


\section{OUR PRICELESS SWALLOWS}

with such a swarm catching flies all day about our place you couldn't make me believe that there were not less flies than there would have been without them."

"Don't they catch other insects beside flies?" asked Ned, becoming evidently interested. "Yes," I told him, "they are great on mosquitoes and about every sort of small flying insect. The Government ornithologists of the Biological Survey say that in the South swallows feed upon the dreaded boll weevil, and they are getting up a crusade to try to protect the swallows and introduce them to regions from which they have been driven out. One good method is to kill off the English Sparrows around their colonies, and also to put up suitable boxes for the kinds that use them. Of course boys ought not to disturb them, and the owners of barns where they build should welcome them, even though they make some dirt to clean up. They are well worth any trouble they may cause."

After this little talk about swallows, Ned helped me drive out the flies so that there would be none of them on my bird article, and I went to work again in peace. Besides helping me in this swallow-like occupation of chasing flies, Ned promised to go with me that afternoon and help me photograph a nice Barn Swallows' nest with four nearly fledged young, which were now about to leave.

It was a pretty hard proposition, Ned thought, when he saw the nest, on the projecting end of a timber inside a barn, away up under the roof where it was quite dark 


\section{OUR PRICELESS SWALLOWS}

and almost inaccessible. However, I thought there was a way. We got a long ladder, and I climbed up on a beam which went rather near the nest. I pulled the ladder up after me and placed it across two beams. Then Ned handed me up some boards and I made a little platiorm on the ladder to stand the camera and tripod upon. The camera set up on the tripod could now stand close to the nest, but it was too dark even to focus. Howerer, I was ready for that difficulty. I had brought a good-sized mirror, and now I asked Ned to stand just outside the barn door in the strong sunlight and throw up the reflected light upon the nest. It was easy now to focus. Then I held up a smaller mirror which I carried in my pocket and had Ned throw the light on my mirror, and I in turn threw it down into the nest upon the backs of the young birds, and thus I made some successful quite short exposures. Then I brought down a young swallow, posed and photographed it outdoors, put it back into the nest, and the work was done, and well done-thanks to my valuable assistant.

Probably the Barn Swallow is the best known of the six species found in our Northern and Eastern districts -the bird with the forked tail, reddish breast and shiny blue-black upper parts. They build nests of mud and straw on beams inside barns and sheds. The settlement of North America by the white man has changed the habits of many of the birds, notably the swallows, and among them this particular kind. Its 


\section{OUR PRICELESS SWALLOWS}

original preference was for rocky caves as a nesting site. Just once in my life have I found a nest thus situated. It was in a cave on lonely Seal Island, which lies twenty miles off the rugged coast of Maine, in Penobscot Bay.

Our Barn Swallow is such a happy, friendly bird that nearly everyone who knows it lores and admires it. We enjoy its merry twitterings as it darts about the barn, and are pleased at the grace with which this greyhound of the air doubles and turns. When we go out for a drive, it is a pretty sight to see them circle about us, catching the insects which our advance starts from the grass or weeds along the country roadside.

Perhaps next in familiarity comes the Eave or Cliff Swallow. This is the other kind which frequents the barns. I; builds bottle-shaped nests of mud pellets up under the eaves, which are often clustered thickly together and partly built.one upon the side of the other. In the primitive days these colonies of nests were built on cliffs, and in some parts of the IVest they are built there even yet. So the bird is the genuine Cliff Swallow out there, and the Eave Swallow with us. Originally there were no Cliff Swallows where there were no cliffs, but with the country's settlement they spread nearly everywhere, and the dates are on record when they first appeared in various localities. This bird looks quite different from the Barn Swallow, and can be told by its nearly square tail, the pale reddish patch at the base of the bill and on the upper rump, and the light under-parts. 


\section{OUR PRICELESS SWALLOWS}

I have photographed the nests by putting up a ladder under the eaves, driving my screw bolt into the side of the barn, screwing the small camera to it and making long-timed exposures, since the nests are in t'ie shade. To get the adult birds from life, I await quietly beneath the nests on some low barn, with my reflecting camera in hand, and snap the birds as they fly to their nests. When the young are just beginning to fly they are quite tame and one can often walk up close to them with the camera.

The nests of many swallows get very lousy, like the Phobes', and it was owing to this that I once had a rather severe punishment for meddling with the Eave Swallows when I was a boy. I wanted some swallows' eggs, and, after climbing up to some nests by means of a ladder, was trying to get my fingers into the narrow entrance of one of them, when down came the nest and smashed all over my bare head. In a moment I was swarming with bird lice from head to foot-and what a time I did have! It was days before I got rid of them all, and I was sore in every member from their bites and my scratching. Fortunately it was vacation time, and I was able to keep aloof from most of mankind.

Then there is the Tree Swallow, the kind with the pure white breast and glossy steel-blue back. How they used to swarm on the marshes and on the telegraph wires, when I was a boy, in August when they were getting ready to migrate! But now their numbers seem pitifully small in comparison. Originally they nested 


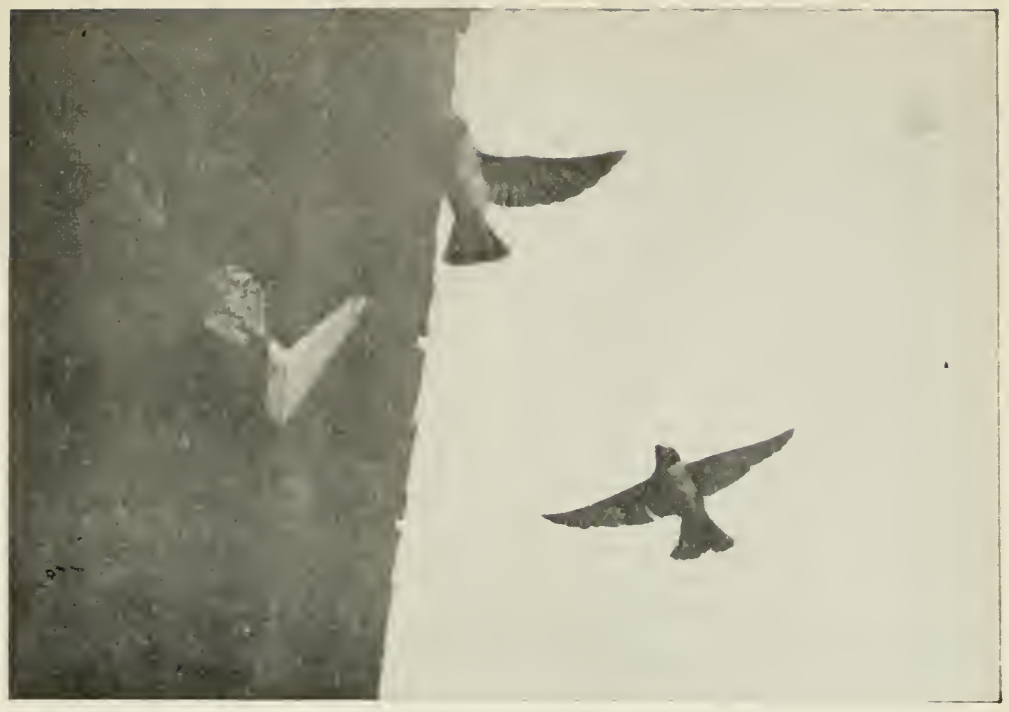

Eave Swallows. "Snap the birds as they fly to their nests" (p. 182).

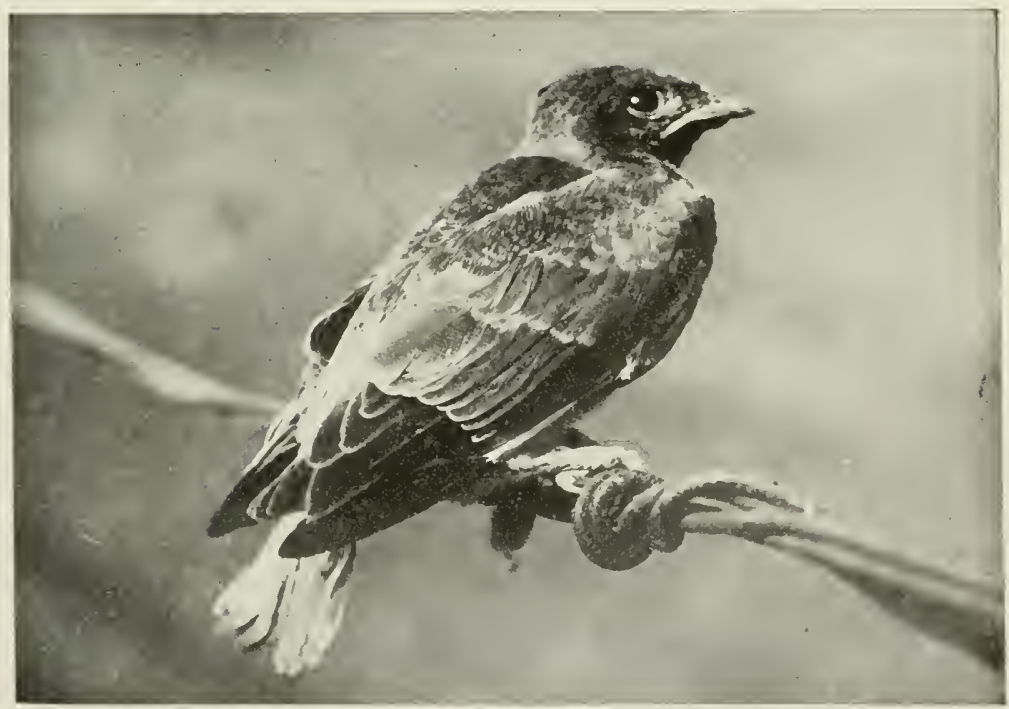

Fledgling Eave Swallow. "Just learning to fly" (p. 18:). 


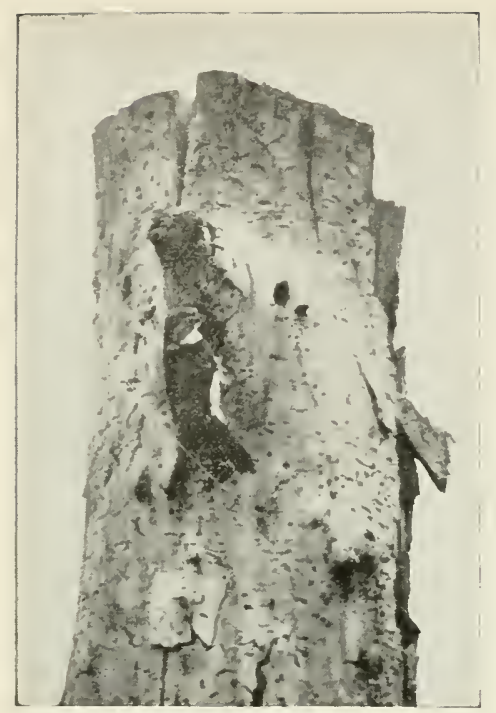

Tree Swallow (male) at nest.

"Alighted at the entrance with a fly" (p. 181).

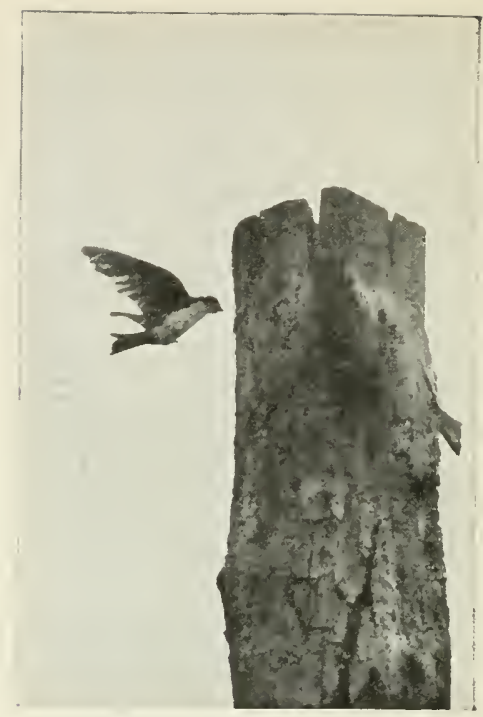

Tree Swallow. "Snapped him as he approached the stuls" (p. 18t).

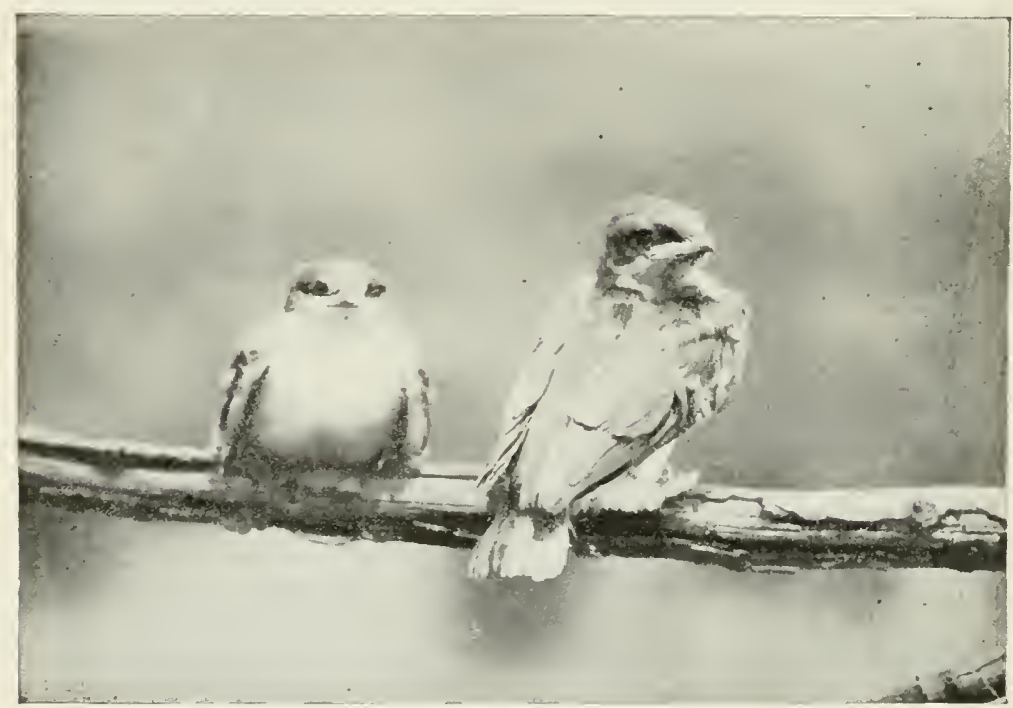

Young Tree Swallows. "About ready to leave" (p. 184). 


\section{OUR PRICELESS SWALLOWS}

in cavities of trees. Then, in well settled localities, they changed to the bird boxes which kindly disposed people put up for them. But the English Sparrow came and drove them out, and now they have gone back to the hollow trees again.

Out in North Dakota, I have seen pairs of them flying in and out of hollows in low trees along the shores of rivers and lakes, and I was wishing that I had taken the time to photograph them. So it was pleasant to me to find a colony of them near my home nesting in stubs in the overflowed woodland where I have told of the woodpeckers nesting so abundantly. Some of the stubs which they had chosen stood out in pretty deep water and the holes were rather high up. I was standing on the "corduroy" roadway across the swamp and wondering how in the world I was going to work it to get some pictures, when I saw a Tree Swallow fly into a hole near the top of a low stub only about five feet from the water, the stub being only a yard out from the road. I waited two weeks or more till the young were hatched, and then with my reflecting camera and a lot of plate holders, I paid a visit to the nest. The male bird sat on a low branch of another stub, quite near the nest hole, and let me walk quietly up and snap him. He flitted to another stub and I got some more pictures of him. Meanwhile the female flew to the nest with a fly, so I sat down on the edge of the roadway partly behind a bush, with the camera on my knees, aimed at the nest. For a few minutes the birds flew 


\section{OUR PRICELESS SWALLOWS}

about twittering, excited by my presence. But I sat still, and presently the male ventured. I snapped him as he approached the stub, and he flew back without entering. But in a moment he alighted at the entrance with a fly, and, not heeding the sound of the shutter, entered, fed the young, and emerged carrying a sac of excrement. By this time I had changed the plate and caught him as he left. Then the female came, and they were constantly going and coming, giving me all the snapshots I wanted. Later, when the five young were about ready to leave, I took out two of them and posed them, and then put them carefully back into the hole.

One day I came out from the woods on the adjoining hill, hundreds of feet above this morass, overlooking the whole tract. It was a lovely panorama of high rolling hills, with two lakes nestling in the valley, and, aided by my strong field glass, I actually could see the old woodpecker hole in the swallow stub, and see the swallows enter and leave the cavity as they fed their young.

Still another familiar species is the Bank Swallow, the smali brownish fellow that digs out burrows in gravel banks near ponds or streams. They are quite common, and a number of banks or cuts in my neighborhood each boast of a little colony of a dozen or more pairs. The birds arrive toward the end of April, and presently go to work digging their burrows, and then make trips to poultry yards to pick up feathers with 


\section{OUR PRICELESS SWALLOWS}

which to make soft lining for the nests, that the very fragile pure-white eggs which are to be deposited may not be broken.

One day I visited a colony situated in a gravel cut, just off a main road. The burrows were not deep, and from one of them I took out a parent bird which was incubating, having previously set up my camera focused on a hole, and, placing it at the entrance, secured a snapshot before it escaped. Meanwhile I had allowed the horse to graze by the roadside unhitched, watched over by Ned. Just ahead there was a rise of ground and a turn in the road. I had not thought about the possibility of an automobile coming along, but, as luck would have it, one came just then, going at very moderate speed. Before I could get back the horse broke away from Ned, shied into the fence, and then dashed off with the shafts, leaving the rest of the vehicle hung up. The animal only ran to the next farmyard, where it stopped and was caught. The driver of the machine was a gentleman. He stopped, proffered assistance, gave his number, and so on. Though I was out a buggy, I did not sue him, as he had been so polite, and I was at fault for leaving the horse as I did. But the country roads are very narrow, and these engines put residents and visitors in the country in jeopardy of their lives. It is not only illmannered, but lawless and criminal for anyone to invade country roads with an automobile and not drive with the utmost care, stop when he is asked by the 


\section{OUR PRICELESS SWALLOWS}

driver of a horse, and in every way be considerate, in view of the peril to life and limb which he is creating. Machines are impracticable in the country for at least half the year, and people living there are compelled to keep horses. Were all autoists gentlemen like this one just mentioned, people in the country would not be put to as much inconvenience and danger as at present they suffer, many, especially women and children, being afraid to drive or ride out, and thus are compelled to stay at home.

There is another swallow, similar in appearance and habits to the Bank Swallow, which is not so well known -the Rough-winged Swallow. They are not often seen north of the Middle States and are common only in the West. At a distance they are distinguishable from the Bank Swallow mainly by being a little larger and having uniformly dark under-parts. Frequently they nest on the timbers under bridges, or in crevices of abutments, although they also nest like the Bank Swallow. Even Audubon did not distinguish them from Bank Swallows until he happened to shoot some specimens. So it will be well to watch for them among the supposed Bank Swallows, and some day we may add this rather rare bird to our list.

Some people call the Tree Swallow the Martin, but the genuine Martin is the Purple Martin, a larger species, the male of which is entirely of a dark glossy steel-blue color, the female duller, and paler below. They are beautiful and useful birds, but unfortunately 


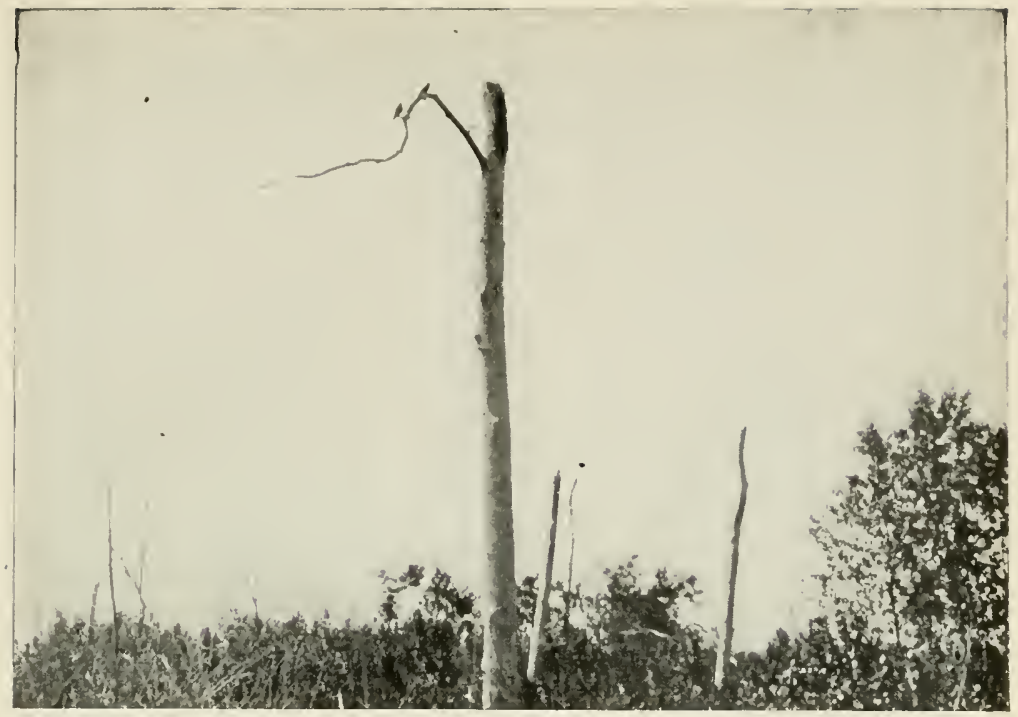

Purple Martins near their nest in hole of stub. "Took a picture of a pair" (p. 187).

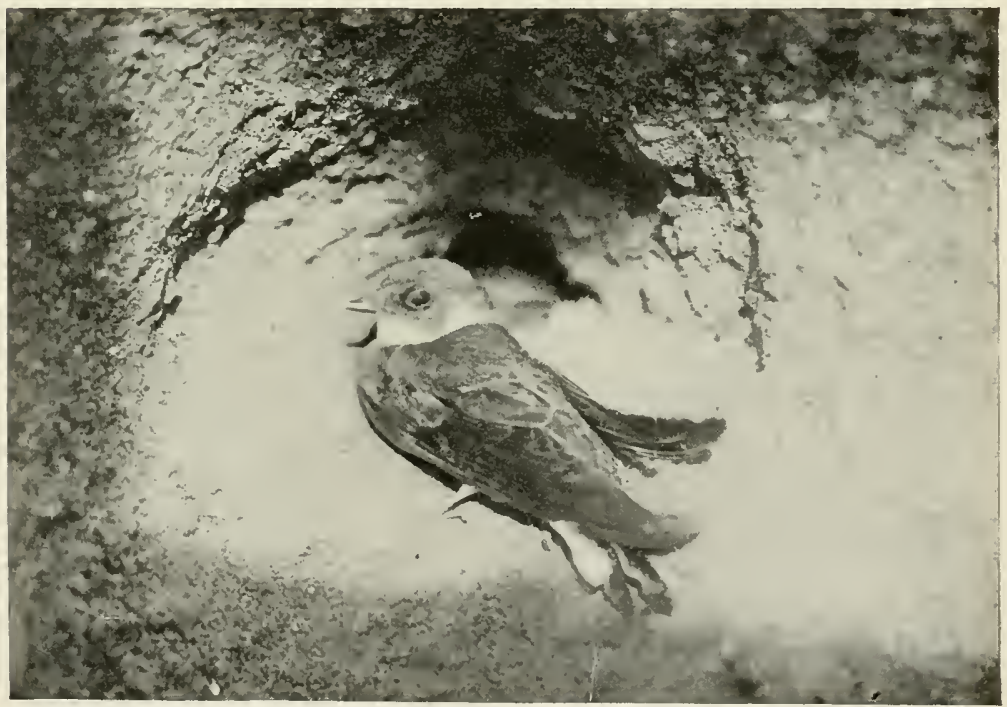

Bank Swallow at nest-hole in gravel bank. "Secured a snapshot" (p. 185). 


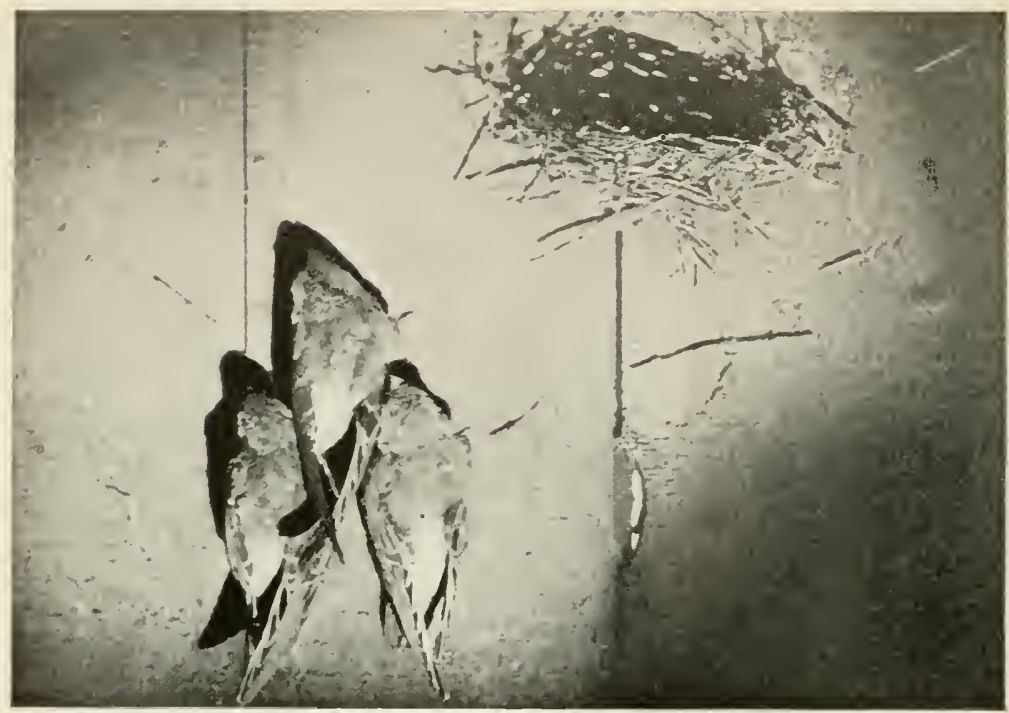

Young Chimney Swifts by their nest. "Clinging . . . like so many bats" (p. 189).

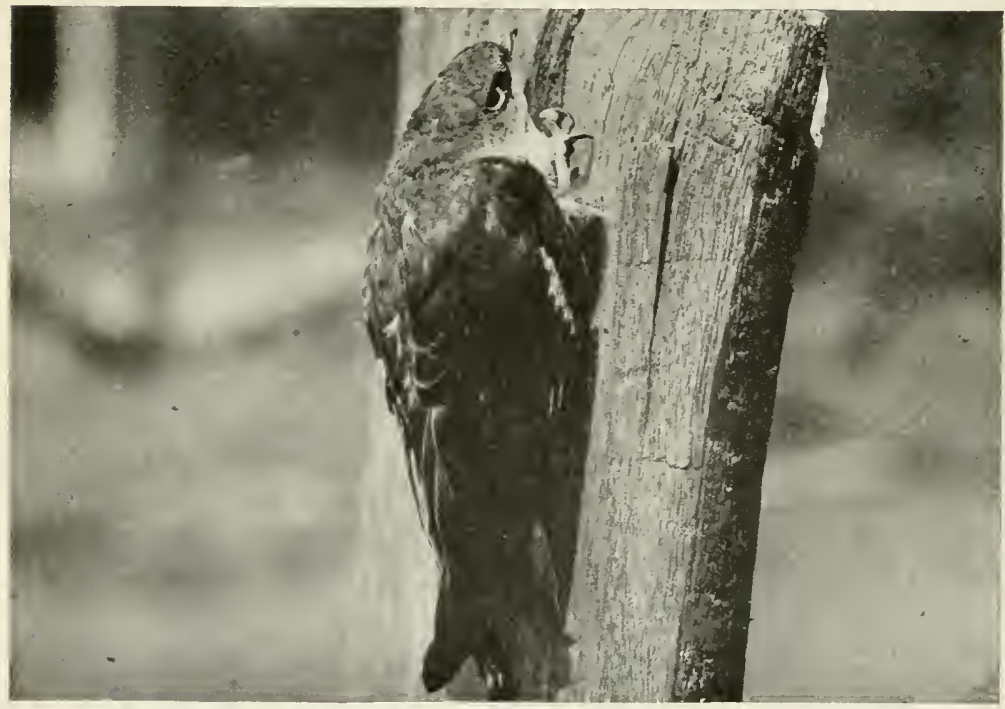

Young Chimney Swift. "How they cling and brace themselves" (p. 189). 


\section{OUR PRICELESS SWALLOWS}

are very tender, and late cold storms, combined with the attacks of the English Sparrow, have almost exterminated them in the New England States. In populated regions at present they generally breed in bird-boxes which people are glad to prepare for them. Sometimes, after prolonged cold rain storms in June, whole colonies of Martins, old and young alike, have been found dead in their nesting boxes. I never see them now except as migrants. Their original manner of nesting was in hollow trees, like the Tree Swallow. Out in the Turtle Mountains of North Dakota I once found them breeding quite plentifully in the poplar timber, and took a picture of a pair of them as they alighted on the branch of a stub near their nest cavity, an old woodpecker hole.

We have just one more bird to tell of in this chapter, the one that people persist in calling the Chimney Swallow. In general appearance and habits it is swallow-like, but in structure it is quite different, and belongs to the family called Swifts. So let us get used to calling it by its right name, Chimney Swift, and be accurate.

Its feet are so weak and cramped that it does not perch, but clings to a perpendicular surface, such as the inside of a chimney or a hollow tree, propping itself from behind with its peculiar tail, each feather of which ends in a sharp spine or spike. But in flight it is master of the situation, and well deserves its university degree of Swift. Almost ceaselessly, oftentimes by night as 


\section{OUR PRICELESS SWALLOWS}

well as day, it is awing, tireless in pursuit of fying insects. It has been estimated that each swift flies a thousand miles every day, yet it never seems to weary.

Under primitive conditions, before the settlement of the country, the swift resorted to hollow trees for rest, shelter and nesting. But now it seldom occupies any other retreat than a chimney. In the autumn, when flocking preparatory for its migration south, I have seen assemblages of them at dusk drop into some selected chimney in a steady stream, until thousands must have been clinging to every arailable inch of brick inside.

They return to us about the last of April, but are late in nestirig, for ordinarily the eggs are not laid till July. During June they may be scen darting over the clead tops of trees, hardly pausing an instant in their flight as they grasp and wrench off a twig. Having secured one, the bird takes it down the chimney and sticks it to the brick wall with gummy saliva, which she ejects. This is continued till the curious basketlike structure has been completed, and then four or five elongated pure white eggs are laid. Many accidents occur. Rains wash down the nest, or the young fall down into the fireplace or pipe below, where they are likely to be left to starve. The brood of swifts make considerable racket, and the descent of the old birds into the chimney causes a rumbling sound lilie distant thunder. They drop a good deal of dirt, too, down the chimney. But they amply pay for their 


\section{OUR PRICELESS STIALOWS}

misdemeanors in the multitude of flies and mosquitoes which they destroy,

It is a hard matter to photograph a nest, owing to the narrowness of the chimneys. But I was fortunate in happening upon a very peculiar nesting site. A pair of swifts chose to build in a barn. Up near the top of the hayloft, near an open window, for the past three years they have stuck their curious nest to the plain board wall inside. The first year they raised but one youngster and the next season four. The third season they built the nest, but for some reason did not lay the eggs there.

I photographed this nest in the same way that I photographed the young Barn Swallows, with the help of Ned, the ladder and the mirrors. The second year I paid my visit when the young had just crawled from the nest and were clinging to the boards near it like so many bats. One flew off, but I photographed the other three, and then put one back in the nest and took a picture of it there. After that I carried one outdoors in the light and took some pictures showing in detail how they cling and brace themselves with the tail.

A pair of them build every year in one of my chimneys, and this year, for some reason, the eggs did not hatch. Ned wanted to get them as curiosities, so he made a small scoop net at the end of his butterfly net pole and succeeded in landing the nest and two out of four of the eggs.

A well-known naturalist once told me that it seemed 189 


\section{OUR PRICELESS SWALLOWS}

to him that the swift in flight used its wings alternately. It would be an interesting bit of sport and scientific research combined to secure a series of flight pictures of the swift and try to find this out. I have thought that sometimes I would squat on the ridge pole by some favorably located chimney to which swifts resorted and see if I could get some pictures. Who else will try it? 


\section{CHAPTER XII}

FOUR NEIGHBORS DIVERSE

\section{(Tanagers, Waxwings, Shrilies, Vireos)}

TED came in one day in May, when the migration was at its height, and reported that he had seen a flock of male Scarlet Tanagers, six of them together, along a roadside, and asked if it was not a rare thing to find so many at once. I told him that it was rather unusual, but that I had occasionally seen such an occurrence at this time of year. They winter in Central and South America, and the males start first for the North, as is the case with many other birds, trusting to the females to come along later and help in setting up housekeeping. To see so many of these black and scarlet birds at once would make one think that they were more abundant than they are. But most people think it quite an event when they see even one. Though they are not rare, they are retiring birds and keep mostly to the woods, so the average person hardly ever sees them.

I went on to tell Ned that, if we lived in tropical America, the brilliant tanagers would not seem so remarkable to us, for there they have great numbers 


\section{FOUR NEIGHBORS DIVERSE}

of them. Indeed there are so many kinds that instead of telling about tanagers, waxwings, shrikes and vireos all in one chapter to even things up, as we are doing now, we might have to make a whole book about the tanagers alone, for, actually, there are said to be three hundred and fifty species of tanager in Central and South America, a good many more kinds of birds than we are telling about in this whole book. Of all these tanagers, only five reach the southern border of the United States, and only one, the Scarlet Tanager, is found, except as a straggler, in our northeastern districts.

The four bird families named in the heading of this chapter follow each other in this order in the classification, except that we have taken out the swallows to treat by themselves-yet it is curious and remarkable how diverse these neighbors are. Not only are they entirely distinct in form, habits and coloration, but, taken as families, there are other interesting points of difference. For instance, the tanagers, as we have said, are a tremendously large group and are confined to the Western Hemisphere: but of the waxwings, which are American also, there are only two known species that certainly belong to this group. The shrikes, on the other hand, belong largely to the Eastern Hemisphere, for out of two hundred kinds America can boast of but two. The vireos are peculiarly American, and there are fifty species, but of these we only see six in northern and eastern North America. 


\section{FOUR NEIGHBORS DIVERSE}

The female Scarlet Tanager is not a scarlet tanager at all, but a dull greenish-olive one, and very few people would suspect her relationship to her brilliant husband. Indeed, she generally comes into publicity, if at all, as it were in his reflected light. First we see the male, about the most conspicuous object in the woodland landscape, and then, looking about very sharply for his companion, we finally make out her demure and inconspicuous form among the foliage. It is well that she is not as conspicuous as her husband, for every marauder would discover the nest, and presently there might be no more Scarlet Tanagers.

The nest is generally built in the woods out toward the end of some horizontal branch, often in an oak, and as high as twenty feet from the ground. But I have also found them in saplings no higher than one's head, in pastures close to the edge of the woods, in wild apple trees or abandoned orchards grown to scrub. In one spot of this latter sort I recently found three old nests, in early June, and saw the pair of tanagers loitering about, but could not trace them to their new home.

There is another decadent orchard spot near my home, on a hillside, by the edge of woods, all grown up to briers and scrub. The season before the one just mentioned, on the twenty-fifth of May, I noted a new but uncompleted nest on an extending branch of an apple tree. No bird was about, and I was uncertain to what species it belonged-either. Rose-breasted 193 


\section{FOUR NEIGHBORS DIVERSE}

Grosbeak or Purple Finch I thought it would prove to be. On June first the nest held four eggs, which looked like tanagers', but there was no bird in sight. Next time, however, the female tanager was on the nest. It was not favorably situated to photograph, but I thought I would pose the young later, when they were of the right age. But young land birds grow surprisingly fast and I must have waited just a little too long, for in a Wood Thrush's nest near by, in which the eggs were laid at about the same time, the young were ready to leave, and the tanagers' nest was empty. But I photographed a nest with eggs on a sapling in the roods and so have at least that much to show. Once I came near getting a good snapshot picture of a male on a wire fence with my reflecting camera. I crept up quite near, but the bird started to fly just as I snapped, so the picture was not very good.

Of the tro species of waxwings, the Bohemian Waxwing is a very rare winter visitor from the far North, and I have never seen it alive. The other, the Cedarbird, is a common and familiar bird, much admired for its soft brown plumage, its wary crest, the yellowbordered tail, and the little red "sealing wax" feather tips that some of them have on their wings. Most of the year they go in compact flocks, making a lisping note as they fly, and alighting close together on the trees. These flocks sometimes appear in the winter, and one of my earliest recollections about birds is that one bitter cold day in February a large flock of these 


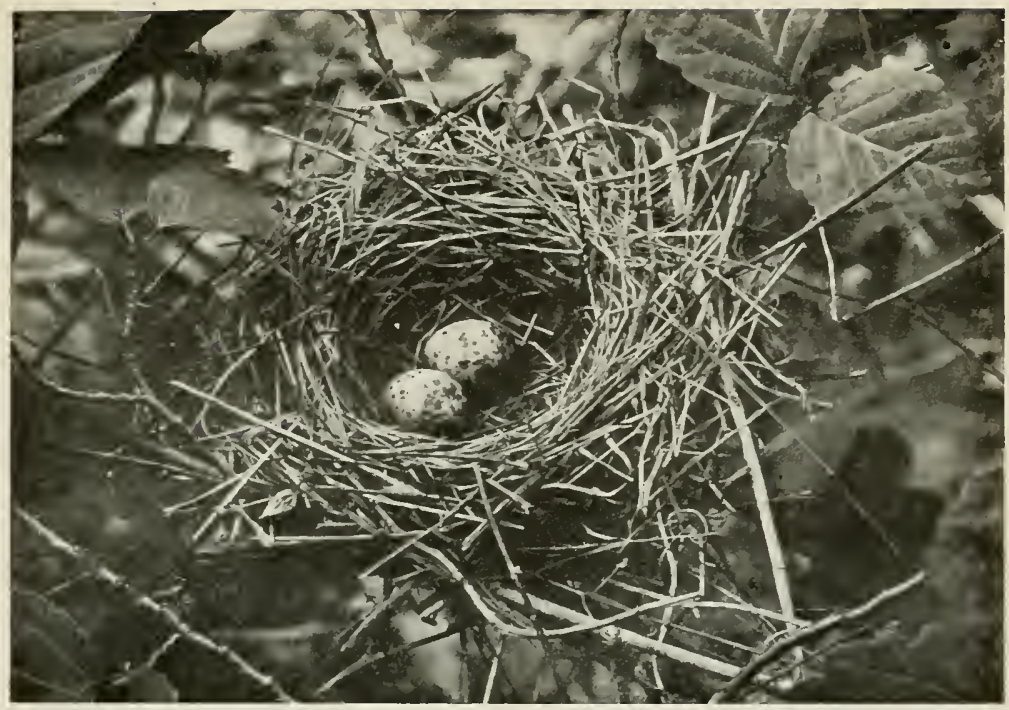

Nest of Scarlet Tanager. "On a sapling in the woods" (p. 194).

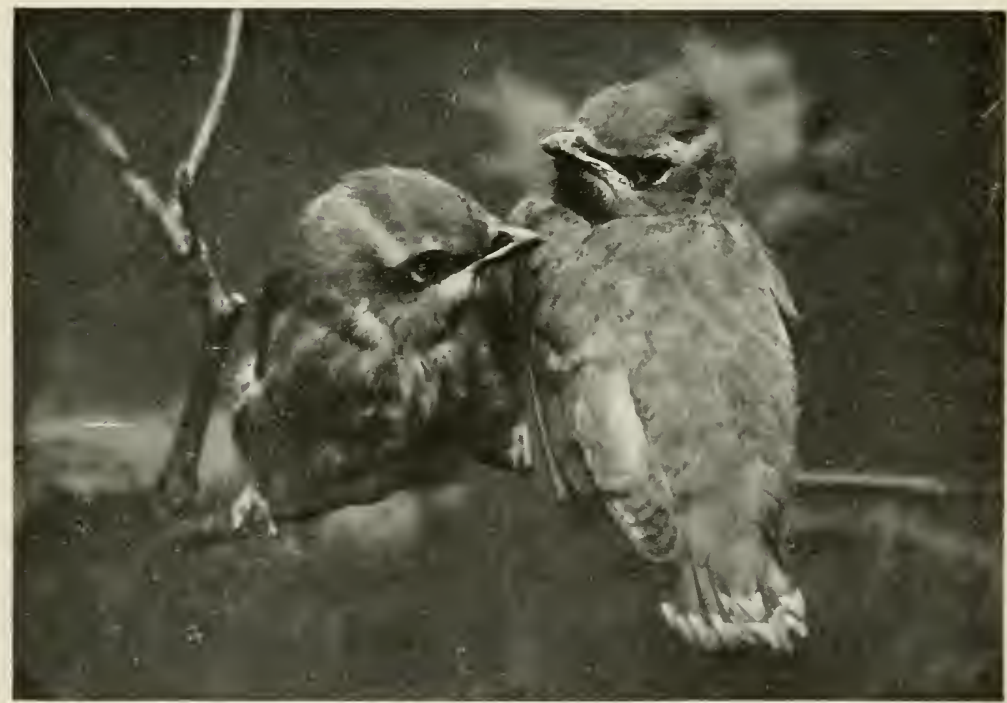

Young Cedar Waxwings. "Assumed pretty positions" (p. 196). 

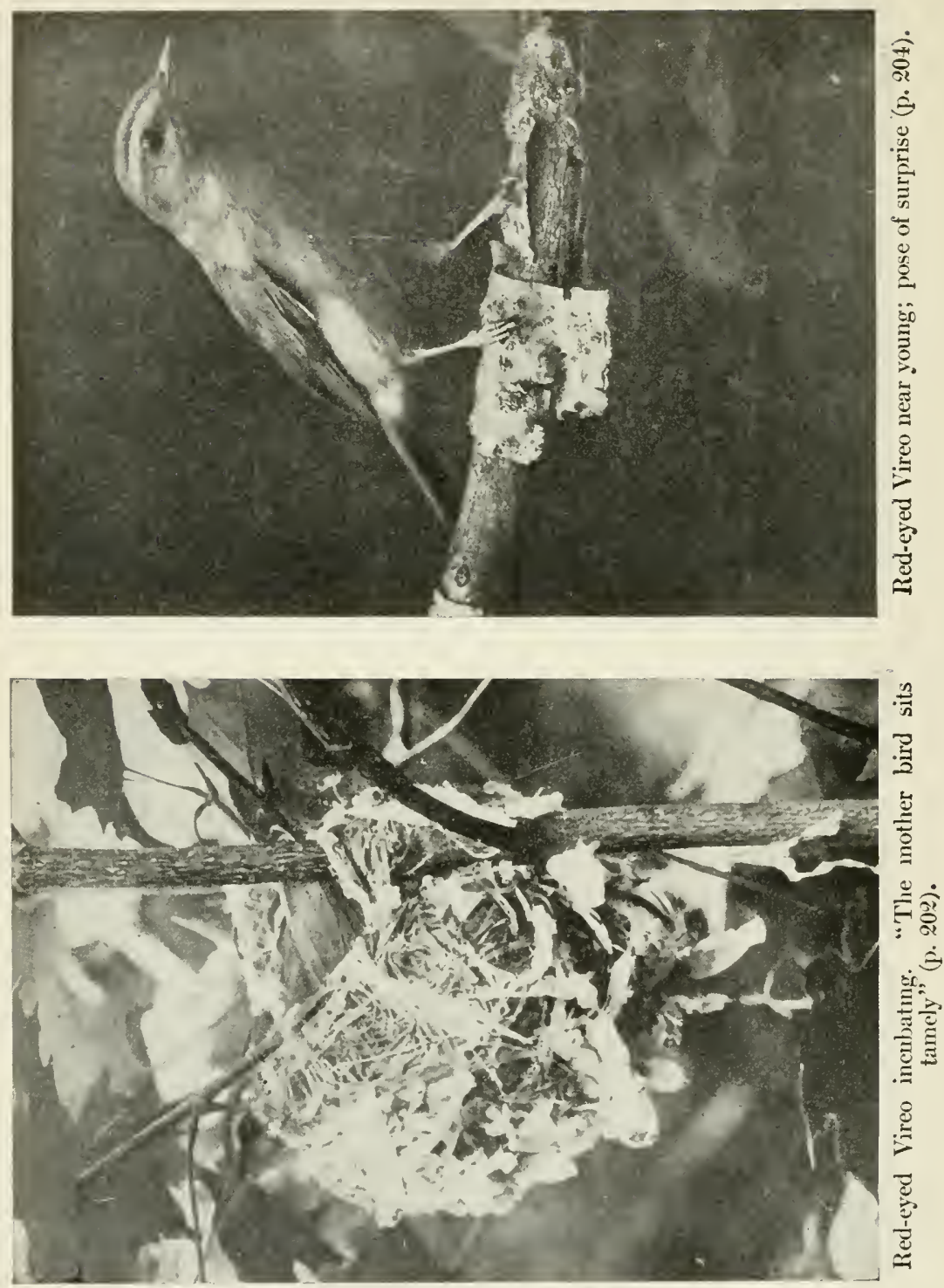


\section{FOUR NEIGHBORS DIVERSE}

birds was flying about our garden, and we picked up one dead, which we had mounted. How I did admire it!-much, I suppose as my baby girl feels, who pats the stuffed birds in my study every day, saying, "Chicky, chicky."

In early spring, usually by March, one begins to see more and more flocks. These large companies break up soon into smaller ones. But after all the other birds have paired and are nesting, still we see flocks of Cedar-birds and Goldfinches, our two greatest delinquents. The Cedar-bird is the first of these two to yield to the inevitable, and by late June or early July we begin to miss them. But if we use our eyes a little we can find a nest here and a nest there, preferably in an orchard tree, but also in shade trees in gardens or along village streets. The pretty mother sits quietly on her compact nest of straws and rootlets, incubating her four or five spotted eggs, which can be distinguished at once from those of any other kind. If we disturb her we shall hear the lisping notes which were familiar in the spring. One day in midsummer a boy came to ask me what sort of a bird it was that had a nest in an apple tree by his home and kept saying, "Listen to me, listen to me." I told him that I never heard a bird say that, so I went with him to see, and found that it was a Cedar-bird.

They sometimes nest in my apple trees, and I find nests elsewhere readily enough, but most of them are out on slender branches or in deep shade, giving little 


\section{FOUR NEIGHBORS DIVERSE}

chance for photography. However, as though to reward my forbearance in not cutting down a nest to pose in unnatural surroundings, I had an unusual chance to photograph a pair of Cedar-birds from life. In a neighbor's yard, a nest blew down in a thunderstorm, and all but two of the young were drowned or otherwise disappeared. A kind lady rescued the neglected orphans and fed them till they were fully grown and feathered. When I saw them they were at liberty in the garden, and were so tame that almost at once they would fly upon my head or shoulder and beg for food. They were very fond of raspberries, and every few minutes they would clamor to be fed-in their lisping dialect and by beseeching gestures. Handling them did not alarm them in the least, so I focused the camera on a small bush, and fed the little fellows on the desired branch, when they assumed all sorts of pretty positions as I snapped them. After a few days they wandered off, and one afternoon a lady who stepped out on the sidewalk in front of her house was amazed to have a Cedar-bird suddenly alight on her head and then hop to her shoulder, where she could see that it was begging for food. She fed it, and the other one appeared, and they stayed about her horne all day. It is not good, though, for birds to be too confiding, for a cat caught one of them, and it is more than likely that the other perished before long in some such way.

Very different in temperament from the gentle wax196 


\section{FOUR NEIGIIBORS DIVERSE}

wing is the carnivorous shrike. Of the two species, the bold Northern Shrike, or Butcher-bird, is the one with which I am the more familiar. We only have it in winter, from November to about early April. Most often it appears to our view as a solitary, gray-colored bird, nearly as large as a Robin, perched up on the topmost twig of some isolated tree, in a field or by the roadside. While we watch, it may suddenly dive down into the bushes or grass below, perhaps returning to its perch without result, or it may be with a mouse or a poor Tree Sparrow or Junco, grasped by the neck by the strong, toothed beak. If hungry, it will proceed to devour the victim like a little hawk. But at times it seems to kill merely from habit, and will impale its slaughtered victim on a thorn in the thicket, or suspend it in a crotch, and leave it. It is doubtful if this is done to provide for the future. Surely, in cold winter weather, when the meat would freeze solid, the shrike could hardly be supposed to eat it. Sometimes, when one of these birds of murderous taste locates in a town and practices its talents on English Sparrows, we come to feel friendly toward it.

I remember how surprised I was the first time I heard the Butcher-bird sing. It was in March, and on the topmost twig of a small elm on the edge of a field stood a bird which at once I called a shrike. As I drew near I was greatly surprised to hear it warbling away very prettily. At that time I had not read that butchering and musicianship could unite in an indi- 


\section{FOUR NEIGHBORS DIVERSE}

vidual. I should about as soon have expected a hawk to rival the pet Canary. However, I saw that it was a Butcher-bird without doubt, so that day I added to my little stock of bird-lore.

The Butcher-bird nests far to the north, but the other species, the Loggerhead Shrike, is more southerly, and is quite widespread, though rare in the northeastern States. I have found its nest in Florida and seen it a few times as far west as North Dakota. In habits it is a good deal like the Butcher-bird, though more of the sort of singer that one would expect a butcher to be. I have noticed that it seems to like pretty well to perch on telegraph wires.

Somewhat resembling the shrikes in structure, having in common with them the strong, notched bill, the vireos are yet a very different group of birds. They are birds of the foliage, clad in dull green and olive garb which renders them inconspicuous, great destroyers of insects, and of considerable ability in song. They all build neat cup-shaped nests which they hang in a slender fork, usually near the end of a bough. Of the six species that visit us, the first to come in spring, toward the latter part of April, is the Blue-headed or Solitary Vireo. These spccies are all pretty much of a size and quite similar in plumage, and we must look carefully to distinguish them. This one is particularly distinct with the bold white ring around the eyes, bluish-gray crown and sides of head, and short, stubby bill. It is a northerly species, but it 


\section{FOUR NEIGHBORS DIVERSE}

sometimes nests as far south as southern New England and in the Alleghany Mountains.

I have been fortunate enough to find one nest. As I was passing along the edge of a pine grove one June seventeenth, I noticed a vireo's nest in the fork of an extended branch of a sapling, not quite as high as my head. The owner, a Solitary Vireo, was at home, and was surprisingly tame. Though I stood close to her, she did not move, and it was only when I almost put my hand on her that she hopped off and began to scold very angrily. There were four small young in the nest. Unfortunately this was before the days of bird photography, in my boyhood, when the portrait photographer fixed one's head in a vise and made one sit rigid for a fearfully long time. I am certain that the vireo would not have submitted to that.

Last summer I came pretty near finding another nest of this bird. A friend and I had been exploring a typical Northern sphagnum swamp, around which grew a tract of black spruce, making ideal conditions for tempting Northern birds to linger south of their usual range. It was getting toward evening, and we were just coming out of the woods when we heard a vireo singing away with all its might from a pine tree near by. "That song doesn't sound to me just like the common Red-eye," said my friend. "It certainly does sound a little peculiar," I replied, "let's look it up." The pine was a large one, and for a quarter of an hour we vainly craned our necks, while the bird sang on. Finally my 


\section{FOUR NEIGHBORS DIVERSE}

friend threw a stone at random and almost hit the singer, which darted out over my head and went down into the swamp. Presently it began again to sing and we followed it up. For some time it kept itself concealed in the top of another tall pine, but at last it flew down low and gave us a fine view. It was a Blueheaded Vireo. This was in late June and of course the nest was somewhere near by. We made a long, careful search for it, but at last had to give it up and return for supper. It proved impossible for me to visit the spot again.

Another species that is easy to distinguish is the Yellow-throated Vireo. Its bright-yellow throat reveals its identity in a moment. Though found in woodland, it is quite partial to the shaded street or garden, where it finds delight and food in the tall shade trees, from which it sings away blithely all the day. One of my earliest recollections is of a beautiful nest of this species in our garden in Boston, ornamented with many bits of white paper and cotton and lined with beautiful soft plant down. More latterly a pair built at the extremity of a slender limb of an ash tree quite near a window of my present home.

The Warbling Vireo is another species which frequents the tall shade trees of town or village, or even city. It is a plainly-garbed little bird, perhaps the most demure of all the vireos, greenish above and yellowish white below, without distinct markings. The nest is nearly always inaccessible, and were it not 


\section{FOUR NEIGHBORS DIVERSE}

for its voluble singing, it would seem much scarcer than it really is. There is another vireo which is quite like it, a rare migrant, the Philadelphia Vireo, which may be distinguished by uniform pale greenish-yellow color of its entire under-parts.

The remaining other two kinds are named after the color of their eyes, or iris-White-eyed and Red-eyed Vireo. 'The former has a ring of yellowish feathers around the eyes, and is a bird of the swampy thicket, a hard bird to study, as its haunts are so impenetrable. However, I have managed to find its nest, suspended in a low bush in the dense tangle of a swamp, though were it not for the fact that the little fellow is such a capital singer and minic, the most accomplished vocally of all our vireos, even the bird lover might not suspect its presence. Even as it is, with all its fine singing, few people know of its existence.

If there is any vireo at all well-known, it is the Redeyed Vireo, or "Preacher-bird," as some have called it, readily distinguishable by white stripe over the eye. It is one of our most abundant woodland birds, and is also often found in shade trees or orchards. No bird's nest is more often found in the woods than the Redeye's. One winter day, while taking a walk in the woods with Ned and another boy, I noticed a number of these nests on the bare branches. "Boys," said I, "stop a moment and tell me how many vireos' nests you can discover right from where you stand." The boys began to peer about, and after some little time 


\section{FOUR NEIGHBORS DIVERSE}

they made out to find the six which I had already noted. In late spring and pretty much throughout the summer it seems as though one could hardly go anywhere into woodland without hearing the simple monotonous carol of the Red-eye "preacher." If no one listens to his discourse, it makes no difference, for his "preaching" is only intended for home consumption, the expression to his mate of his affection and of their mutual happiness.

The nest is generally in the fork of a sapling, low down, often within four fect of the ground. The mother bird sits tamely upon her three or four white, sparsely-dotted eggs. I have found it easy to stand the camera near by and photograph her, though she snuggles down so deeply into the cup that little of her can be seen save her head and the top of her back.

Of all the many Red-eyes' nests which I have seen, none have proved as interesting as one which I found this last June. I was just coming out of the woods back from the shore of a pond, when one of these vireos, flying into the shrubbery, suddenly encountered me face to face. At once it began to scold, and I saw the nest on a low sprout, just to one side. It was newly finished and contained only one egg, not the vireo's, but of the Cowbird parasite. To help the vireo, I removed it, thinking that now the birds might raise their brood in peace. I kept the nest in mind, and, wishing to photograph young vireos, I returned to it twenty-three days later, at the time when the brood ought to be nearly fledged. As I peered into the nest 


\section{FOUR NEIGHBORS DIVERSE}

I saw that there were young, but imagine my surprise when these young proved to be, not vireos, but two lusty young Cowbirds, about ready to fly. There is no way of knowing whether one Cowbird had laid three times in this nest, or whether it was the work of three different Cowbirds. No doubt these youngsters had thrown out or trampled to death the whole brood of young vireos. I had a good mind to wring their necks, but the foster mother came and acted so distressed, that I decided she had had trouble enough.

But anyhow I was going to photograph the young rascals. It was dark there in the woods, so I carried them some rods out into an open clearing, where I posed them on a branch and used up my last few plates. By this time the old vireo had found us and scolded plaintively from a branch close by. Then it began to dawn upon me that I had been rash in using up my plates so soon. I withdrew a few yards, leaving the camera where it was, close to the young. Within a minute the vireo flew down and gave one of her adopted children a worm, utterly ignoring the camera. I do not know when I ever felt more utterly disgusted at myself for having made such a blunder. Oh, if I only had a few plates! My reflecting camera was in the buggy half a mile away and the sun nearly setting! Putting the young Cowbirds in the carrying case, to keep them from fluttering away in my absence, I ran as fast as I could, got the other camera and plates, and rushed back again. I put the youngsters on the 203 


\section{FOUR NEIGHBORS DIVERSE}

branch and sat down near by with the big camera, ready for business. The vireo, to my delight, went right to feeding the clamorous Cowbirds and I scored half-adozen shots before the western hill cut off the yellow sunshine. I put the youngsters back in the nest, hoping against hope that they would not be gone on the morrow, for I knew that these pictures already taken must be under-exposed, as they proved to be.

All in a flutter of excitement, the next morning, I peered through the foliage as I nearea the nest. "Oh, joy, they are there!' I exclaimed. I thought surely I was all right now, but my troubles were to begin. I posed the young, but they were determined not to stay on the branch, and I had to replace them again and again-scores of times. Besides this, the mother did not show up. After waiting over an hour, I feared all sorts of things, as she had not appeared at the nest while I was removing the young. Finally, just as I was thinking of returning them to the nest, I heard the old bird, and presently she came and gave one a worm. But now it had clouded up darkly and threatened rain, being too dark to photograph. I sat there another hour or more and watched her tuck grubs, flies, raspberries and the like into the hungry mouths. There was the camera staring helplessly at all those splendid poses two or three feet away, and I fairly gnashing my teeth, my proverbial patience almost a complete wreck.

But at length the clouds began to break. The sun peered out, and I scored a shot as a big red raspberry 204 


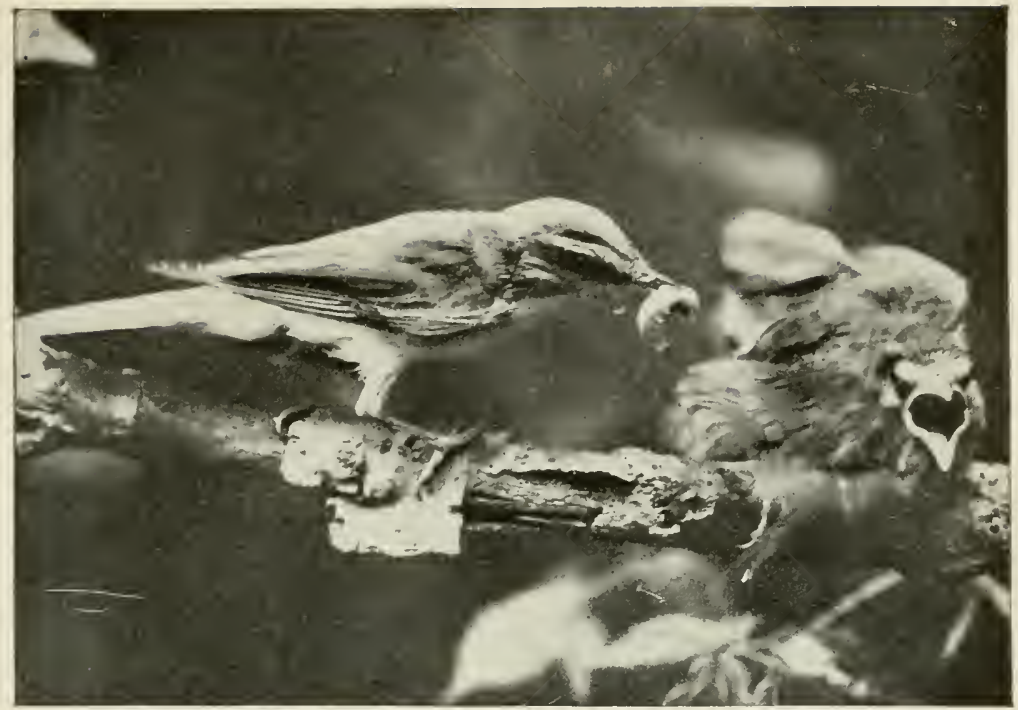

Red-eyed Vireo feeding young Cowbird. "Save one a worm" (p. 904).

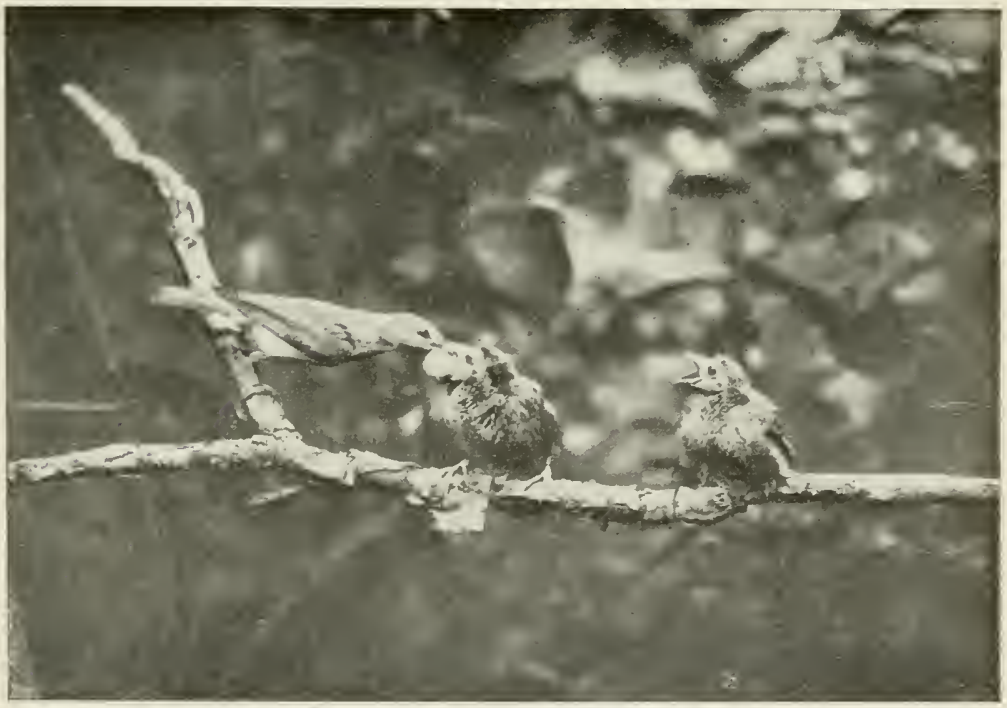

Red-eyed Vireo feeding Combirds. "A big red raspberry . . . shored into . mouth" (PI, 20t-5). 


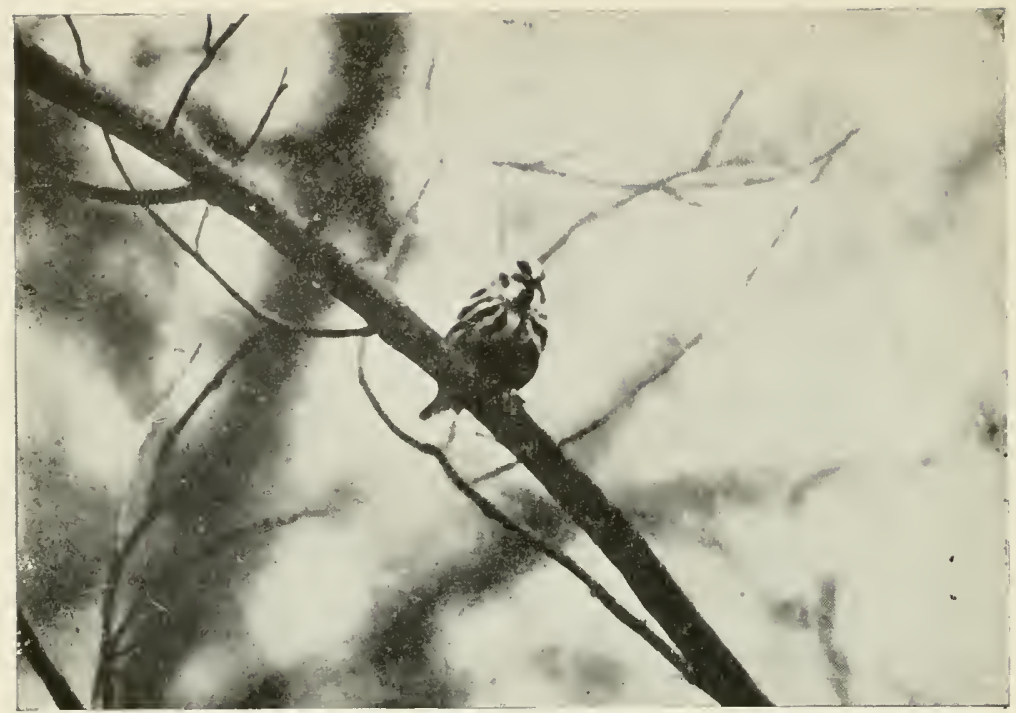

Black and White Creeping Warbler. "Just had time to snap him" (p. \$08).

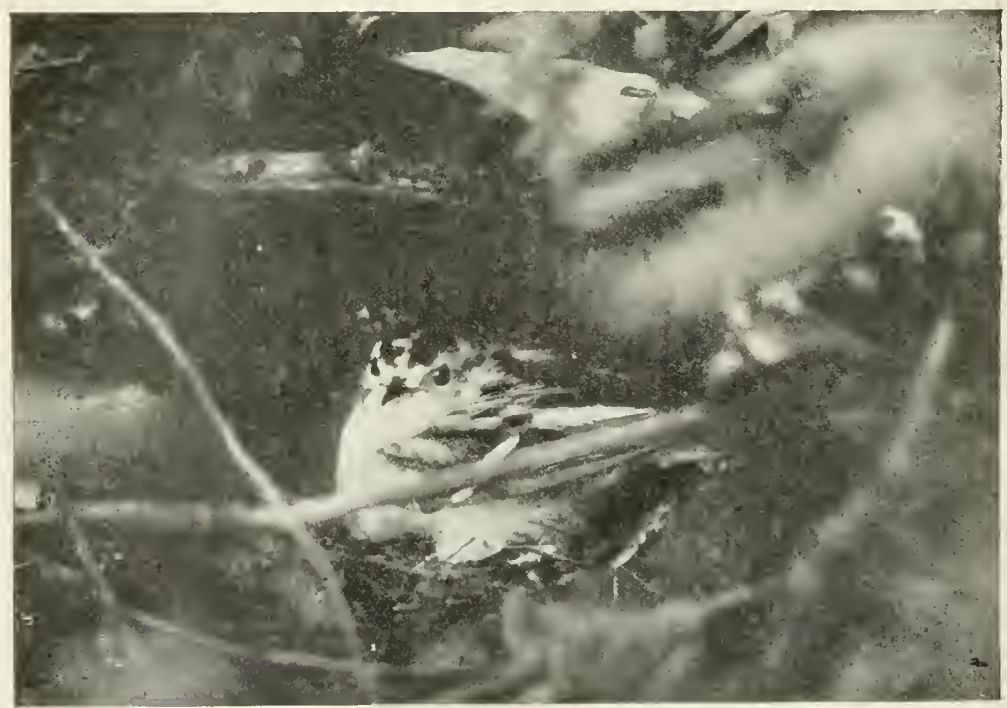

Black and White Creeping Warbler on nest. "By throwing rays of light upon her" (p. 227). 


\section{FOUR NEIGHBORS DIVERSE}

was being shoved into a widely opened mouth. Presently another gleam, just in time to catch on the plate the offer of a great fat worm. For about an hour there were intervals of sunshine, during which feeding was in active operation, and shooting, too! I fired away with that camera till it was, metaphorically, red-hot and when the dark leaden pall shut in again over the sky before the shower broke, I went away rejoicing, leaving the devoted and deluded virco still cramming the insatiable maws of those murderers of her own offspring. 


\section{CHAP'TER XIII}

FEA THERED GE IS

\section{(The Warblers)}

MALKING about a day in June being "rare" always makes me feel like standing up for May. Really I should like to know whether any day in June can surpass a real "warbler day" in Maywhen the fruit trees are white and pink with their canopies of blossoms, when the tints of the young foliage are so exquisite, when the air is soft but not hot, and when trees and shrubbery in woods, swamp, garden, orchard and village streets are fairly alive with variegated warblers, flashing about in their greens, blues, reds and yellows. Yesterday we noticed none, but to-day, this thirteenth of May-lucliy day it is indeed-we can hardly look at an apple tree without having our eyes arrested by movements which are not those of blossoms swayed by the wind. As though the wedding garb of this bridal tree were not rich enough to express the springtime joy, she must be further decked with feathered gems, the crowning jewelry of Nature. It is indeed a joy to live and move and have one's being at such a time-outdoors, of course, for it 206 


\section{FEATHERED GEMS}

were a sin to stay under a roof and behind glass on one of these rare May warbler days.

No sooner had I set foot even upon the piazza than my eye caught the flash as of rubies, and there, in the larch tree on the front lawn were a little company of half a dozen Bay-breasts, the first I had seen in several years. In the clump of honeysuckle bushes was a flashy Magnolia Warbler busily looking for his breakfast. From the Norway spruces bordering the street I heard a snatch of unfamiliar song, and there was the first and only Cape May Warbler I had ever met, a beautiful adult male, whose distinguishing mark was the tan-I almost said sun-burn-of his cheeks. The shade trees rang with the joyous notes of the Redstart, that flame of a bird-and for that matter with a perfect babel of other bird-notes and songs, of Robins, Orioles, Vireos, Purple Finches, Grosbeaks, Wrens, Grackles, and others. The orchard was a place of delight. Parula Warblers, with their bright hues of blue and yellows were fluttering before the blossoms; Myrtle Varblers were making sallies for flies from the bower of petals; Black-throated Greens, more leisurely in motions, were droning out their soporific little ditty. To make more brilliant the occasion, the common but conspicuous Yellow Warbler had loaned us his charms, as had also the spectacular and rarer Blackburnian.

It was fortunate for Ned that he did not have to attend school that day, so we started off to see how many kinds of warblers we could note for the day's 207 


\section{FEATHERED GEMS}

list. Most of the morning we spent in the woods well up the slope of a range of hills on the west side of the river. Warblers of one sort or another were within sight or hearing all the time. Of course the Ovenbirds were calling for "teacher" as volubly as usual. The familiar Black and White Creeper was perambulating the tree trunks and larger branches, singing his simple little trill. One of them stopped for a moment on a branch close beside us to see what we were up to, and I just had time to snap him with my "Reflex" before he started off on his travels. Blackburnians and Bay-breasts were unusually common. In one spot several of both of these were searching for food, in some low undergrowth. I sat down upon a rock near by, keeping perfectly quiet, and presently the pretty little things were close around me, occasionally even within arm's reach, and I secured some snapshots of both species, though the May sun was rather fickle, dodging in and out behind the broken cloud masses that had begun to rise. There was considerable mountain laurel undergrowth, and the male Black-throated Blues were there in full song, and thus conspicuous, whereas it took careful searching to find their silent and somber-hued little brides, some of whom were already, doubtless, choosing nesting-sites, for they build rather early and are common here with us. Redstarts, Myrtles, and Black-throated Greens were also numerous in the woods.

Coming down and out, we ate our lunch upon the 208 


\section{FEATHERED GEMS}

beautiful river bank, and then followed the "river road," with its variety of over-arching trees and fringe of swampy thickets. It is usually a fine place for birds, and to-day it fairly outdid itself. We had gone but a little way when there was a flash of yellow in the roadside thicket and here was the Canadian Warbler, with the necklace of black beady spots hung across his yellow breast, the brilliancy of which was enhanced by the more somber grayish back. This one was but the first of many, for we kept meeting them every few minutes. And now came an even yellower, though smaller, apparition, a Wilson's Warbler, or Wilson's Black-cap, skipping blithely about in a clump of bushes, quaint in his shiny black little feather cap. In the thickets along the river bank were any number of Northern Yellowthroats, and their "witchery-witchery" songs stood out above the general chorus. In the same haunts we spied out an occasional Water "Thrush," or Wagtail, near relative of the Oven-bird, but darker of back and even more heavily streaked on the breast. They were walking sedately through the débris of the swamp, teetering their bodies from time to time. Of course the familiar Chestnut-sided Warblers, they that disport the brown side-stripes, were abundant all along the road, as were Redstarts, Parulas, Yellow Warblers, Black-throated Greens and Myrtles. Up from the road, in a patch of chestnut scrub part way up the hillside, we heard the versatile Yellow-breasted Chat pouring forth his medley, and presently saw him 


\section{FEATHERED GEMS}

perched on a sun-bathed limb, warbling away. Further along, a mountain brook, which flowed through a dark, rocky hemlock-shaded ravine, crossed the road, and here, by the little bridge, we saw a Louisiana Water Thrush, distinguishable from the other species by the throat being pure white, instead of streaked. It is a bird of very similar habit, though southern New England is about its northern breeding-range, whereas the other goes further north. Out more in the open, in a willow, I detected the rather inconspicuous Nashville Warbler, a tiny fellow who has some reddish hairor feathers-on the top of his head.

This made twenty kinds of warblers seen in one day, and we thought we had done pretty well. I wanted to follow up this fine flight on the morrow and perhaps find some more of the varieties. In good season, therefore, I was out and at it, but, strange to say, I could find but very few warblers, save the resident kinds. The host, having fed bountifully that nice day, under the impulse of that strange, restless longing for the spruce and balsam forests of the North, had started on during the night, and by this time were very many miles away. But it was a good season for warblers, and before it closed we both had seen more kinds than we had ever met before in a season, including some which, like the Cape May, were entire strangers. What a delight it is, after one has studied birds for decades ano' thinks he has met about every species around home which he is likely ever to meet, and that he knows them 210 


\section{FEATHERED GEMS}

all, suddenly to encounter one which he has never in his life seen alive.

Such an event occurred this same season one day toward erening. It was about twenty minutes before supper time. I had already been afield that day, and my first impulse was to play on the piano. But something moved me to stroll out back of the village street and look for bird-migrants. On the edge of a cemetery is a narrow strip of woodland bordering a meadow, growing on a rather steep bank. Hardly had I looked over the edge when I saw a warbler in some low shrubbery, half way down the slope. Just as I raised my field-glass it flew, but in that instant I thought I saw bold stripes on the head. Instantly Audubon's picture of the Worm-eating Warbler flashed into my mind. I am fortunate enough to own a set of Audubon and it was probably that which started me out as a child with a passion for birds. Though confident that I had just seen my first "Worm-eater," I must have a better view to be sure. So I followed after it along the strip of trees and shrubbery, hoping that I might start it again. About a hundred yards further on a bird flew from the ground which I thought was the one. It kept flitting on and on, after brief stops among the patches of fern, until I was about in despair of getting a good look at it. Finally it seemed to stay in one spot and I stole up with caution. Peering through the bushes, I was thrilled and delighted to see it sitting motionless on a log, within a very few feet of me, an undoubted Worm- 


\section{FEATHERED GEMS}

eating Warbler, with the bold stripes on its head. With my powerful glasses I could see it as well as though it were in my hands. There it sat for fully five minutes, perhaps about ready for bed. Then I startled it and it darted off. As I returned home I also saw its mate. I hoped they would breed there, as it was an ideal situation for them, but I never could find them afterward. This was the very last of May.

Another rarity to me that I had met a few days before was a male Golden-winged Warbler, splendid with his conspicuous yellow wing-bars, feeding in an apple tree near my home. Still another was a Tennessee Warbler which I encountercd during a furious cold rainstorm in a pasture. The poor little fellow flew out from where he had been sheltering himself under a rock. He was bedraggled and shivering, but he flitted to an apple tree and set to work hunting for supper among the blossoms. In the same pasture I saw a Canadian Warbler so benumbed that it could hardly fly, and I almost caught it. Other birds were about in the same condition, so I was thankful that immediately after this the weather cleared. The storm had been on for three days, and such bad weather in the migration or breeding period is very destructive of bird life.

There are a few of the warblers which we are liable to meet which I have not mentioned. Such is the Yellow Palm Warbler, a common and early species, quite flycatcher-like in habits, which comes to us about mid-April. On the warbler day described above we 


\section{FEATHERED GEMS}

did not see any, and probably they had mostly migrated beyond us. The last of all the tribe to appear is the Black-poll Warbler. It looks a little like the Black and White Warbler, but is different enough, and has none of the "creeper" habits, kecping in the foliage pretty well up and droning out a lisping little ditty. We usually have it lingering till the last of May or the first of June, and in the tardy season of 1907 it remained at least till June 12th. Both the Mourning and Connecticut Warblers are rare; they are found, like their nearest "Swamp-WVarbler" relatives-as certain scientists have classed them-mostly on or near the ground, and they are easily confused, as both are much alike, with dark ashy throat-patch. A careful reading of the descriptions in the Manuals is advisable to fix in mind their points of difference. Then there is the Pine Varbler, the bird with dull, plain yellow breast which runs creeper-like over the trunks and branches of pines, especially the yellow or pitch pine, in regions of poor and sandy soil. With it we may think of the Prairie Varbler, which is likewise locally distributed, in scrubby and bushy tracts, an inconspicuous little fellow, and, in my experience, rather hard to find, unless one is in a region that they have chosen as a center of abundance. Even less conspicuous is the Blue-winged Warbler, which somewhat resembles the Yellow Warbler, but has grayish or ashy wings. It is fond of the edge of woods, and usually is far from common. Where I live they are more apt to be seen in August, after the breeding 213 


\section{FEATHERED GEMIS}

season. The Hooded and Kentucky Warblers are rather common in parts of the Middle States, and there are several rare or accidental species which one might possibly meet, such as the Prothonotary, Brewster's (probably a hybrid), Cærulean and Yellow-throated Warblers.

This makes about thirty-five species of this remarkable family which we may meet in the Eastern and Middle States. About twice that number are known to occur in the entire United States, and there are some thirty more tropical species, making about one hundred known species of Wood Warblers, a group which is peculiar to the Western Hemisphere. Thus the group is second with us in number of species to the puzzling finch family, and it has almost as many puzzles for the beginner in bird-study. The task is easiest in spring, when all of them are in their bright and distinctive nuptial dress. But by autumn they have become more or less dull-colored and nondescript, especially the young, some of which latter can hardly be identified without shooting-such as young Black-polls and young Bay-breasts.

Most of the warbler's are slender, active little birds, living mostly in dry or swampy woodland, where from the foliage they glean their living of insects, grubs and larvæ. They cannot endure much cold, so most of them migrate in autumn to the tropics. A few kinds winter in our Southern States, but only one, the Myrtle Warbler, recognizable by its yellow rump-patch, ever 214 


\section{FEATHERED GEMS}

stays to brave the snow and cold of our Northern winters. They are mostly among the last of our migrants to return to us in spring, May being the great flight time, though we begin to have a few in April, such as the Myrtle, Yellow Palm, Pine, and Black-throated Green.

One nice thing in studying warblers is that in migration they come to our very doors, fairly forcing themselves upon our attention. At such times, careless of their accustomed haunts, they pour, as it were, across the country like a tidal wave. Wherever there is a tree with young leaves or blossoms, we are liable to find warblers at such times, even on city streets. They pour into city parks, and such a place as Central Park, New York City, is one of the very best warbler grounds, for they are fairly congested in such green spots amid weary miles of pavement, which are, for them, truly oases in the desert. So everyone who will may study the beautiful warblers right at home, and, with opera glass to see them and text-book to identify them, learn and enjoy much.

A disadvantage and disappointment, to the contrary, is that the abundance of the migration, as we see it, varies very much from year to year. Some years, as we have been showing, warblers are everywhere. But then again we shall hardly find them at all. In these years, for some reason, the losts either take another route in their travels or else pass over us at night, and we look in vain for their welcome presence on the 


\section{FEATHERED GENS}

blossom-laden fruit trees. Investigations to learn the reason for this are on foot, but as yet it is largely a mystery.

The autumnal migration is by no means a repetition of the delightful experiences of the spring. Silently and almost stealthily the warblers slip past us and are gone ere we realize that they have been with us at all, unless we look carefully for them. No longer do their exuberant spirits reveal themselves in snatches of characteristic song. The pretty nuptial garb is exchanged for the traveler's costume, as though they were expecting to rough it on the long journey amid increasing cold. Nor do they come so much at this season into the gardens and orchards, but keep more to woods and thickets. They are shier, too, and in every way harder to identify. Yet we love them for what they were, and what they will be next spring again. Small bands of them begin to appear in August, and during September the bulk of them pass. By early October most of them have gone.

We should expect from the name "warbler" that these birds were great singers, whereas they are not. Each species in spring has some characteristic, short, simple phrase, or phrases, of song, more or less varied, consisting of several rather weak notes, seldom as many as a dozen. Some of these songs resemble those of other species, while others are quite distinctive. But it is possible for any person of quick ear who will earefully observe these songs to become able to recognize 


\section{FEATHERED GENS}

the warblers by their notes. This is a great advantage in field work, and, for that matter, to know all birdnotes as far as possible. It will save one a great deal of needless searching and instantly call one's attention to the presence of rare species which otherwise would probably be overlooked.

To a great many people there is a special fascination connected with the nesting of the warblers, just as there is in finding the various species on their spring migration. Their little houses are so dainty, and ordinarily so well concealed and hard to find, that the discovery of a warbler's nest is a distinctly interesting and enlivening event. Most of them nest well to the north. Only about seven kinds breed at all commonly in most Middle-Eastern districts-namely, the Yellow, Chestnut-sided and Black-throated Green Warblers, Ovenbird, the Northern Yellow-throat, Redstart, and Black and White Creeper or Warbler. A few more breed sparingly or locally-such as the Chat, Kentucky, Hooded, Blue-winged Yellow and Worm-eating Warblers, especially in the Middle States; and casually there or in the latitude of southern New England the Nashville, Golden-winged, Parula, Black-tlroated Blue, Pine and Canadian Warblers and the Louisiana Water Thrush. Out of about sixteen kinds which at all normally breed in the regions where I have livedMassachusetts and northern Connecticut-I have found the nests of twelve. The number grows very slowly, and only by persistent and assiduous searching. But 217 


\section{FEATHERED GEIIS}

it is one of the beauties of this delightful "Sport of Bird Study" that the unexpected is always liable to happen.

It was thus unexpectedly that I happened upon my only nest of the Nashville Warbler. Ned and I were going up into some woods where a pair each of Broadwinged and Cooper's Hawks nested, on the fifteenth of May. We were following an old cart-road bordering a field and the woods on a side-hill. On the side toward the field was a low grassy bank, about three feet high. Just as I passed close to a certain spot, out darted a small warbler from the grass of the bank, within arm's reach of me, and fluttered over the road, quivering its wings. Now, when a warbler quivers its wings one may be very sure that there are either nest or young near by, so I was on the alert. The bird then flew up into a low tree and began a scolding "chip, chip." After identifying it positively as a Nashville, we went eagerly to work to look for the nest. But, though we examined carefully every inch of the ground, there was absolutely no sign of it, except a little hollow amid some dry grass. I told Ned that I believed the bird had just scratched it out preparatory to beginning to build and that we would look again later.

On the 29th of May we were there once more. No bird flew out and no nest could we discover. Just as I was wondering if we could not have mistaken the spot, Ned's sharp eyes detected a little opening in the dry grass, and in underneath was a dainty little cup of moss lined with grass, and five tiny white eggs with 218 


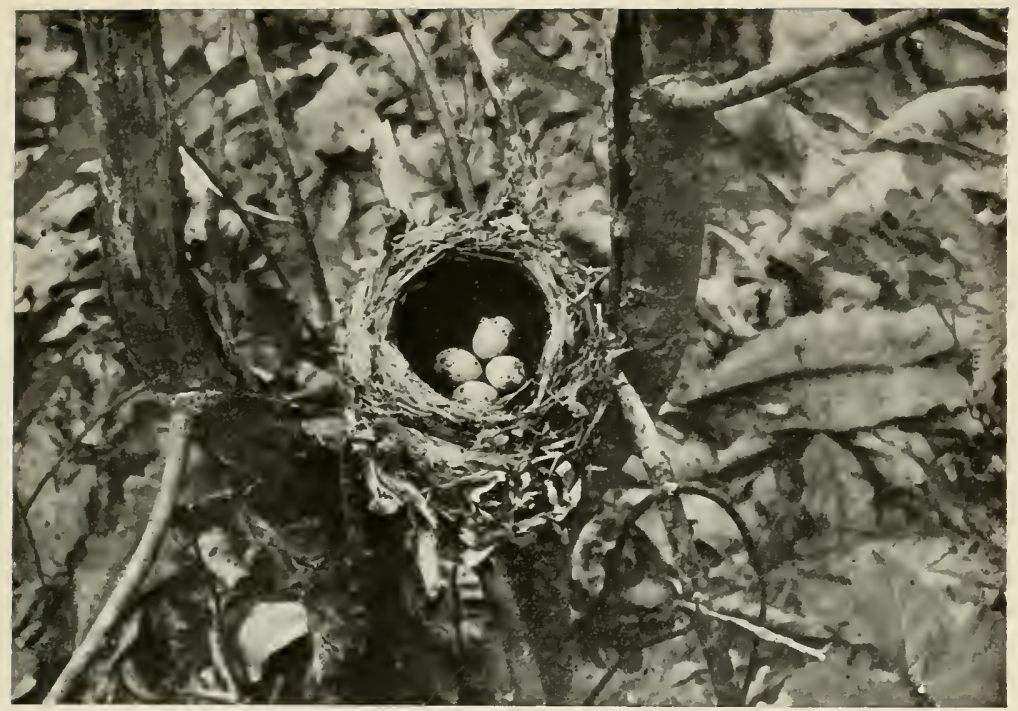

Nest of Black-throated Blue Warbler. "A neat, compactly woven little cup" (p. 219).

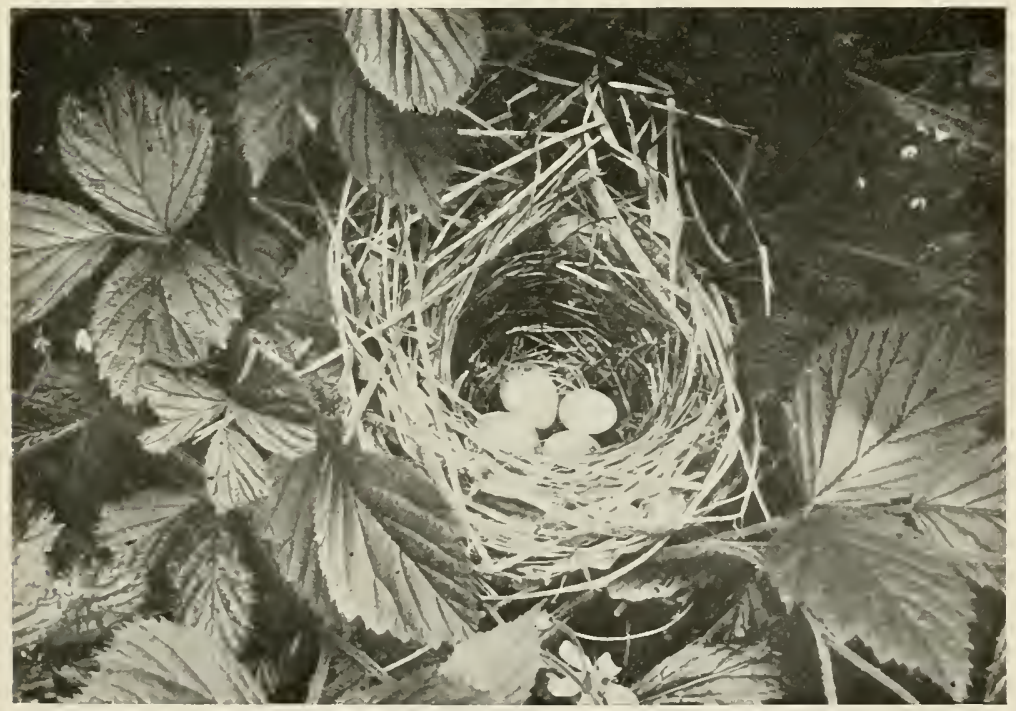

Nest of Y'tlow-breasted Chat, with one runt egg. "Amid the densest tangle of briars" ( $\rho .222)$. 


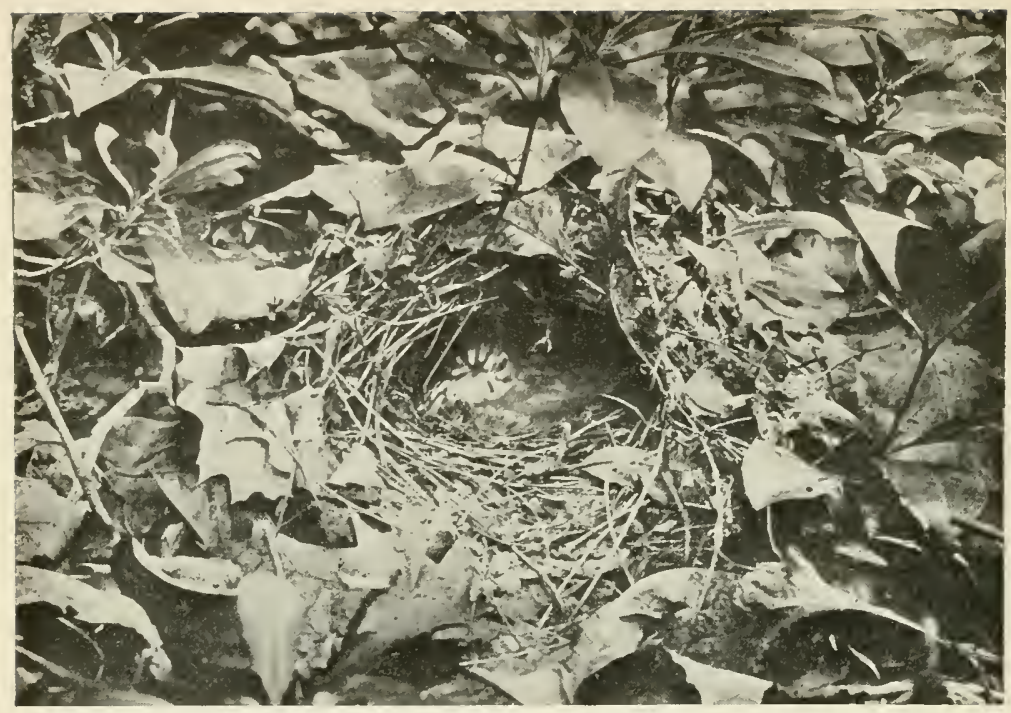

Oven-lird on nest. "Amid the low mountain laurel" (p. ogs).

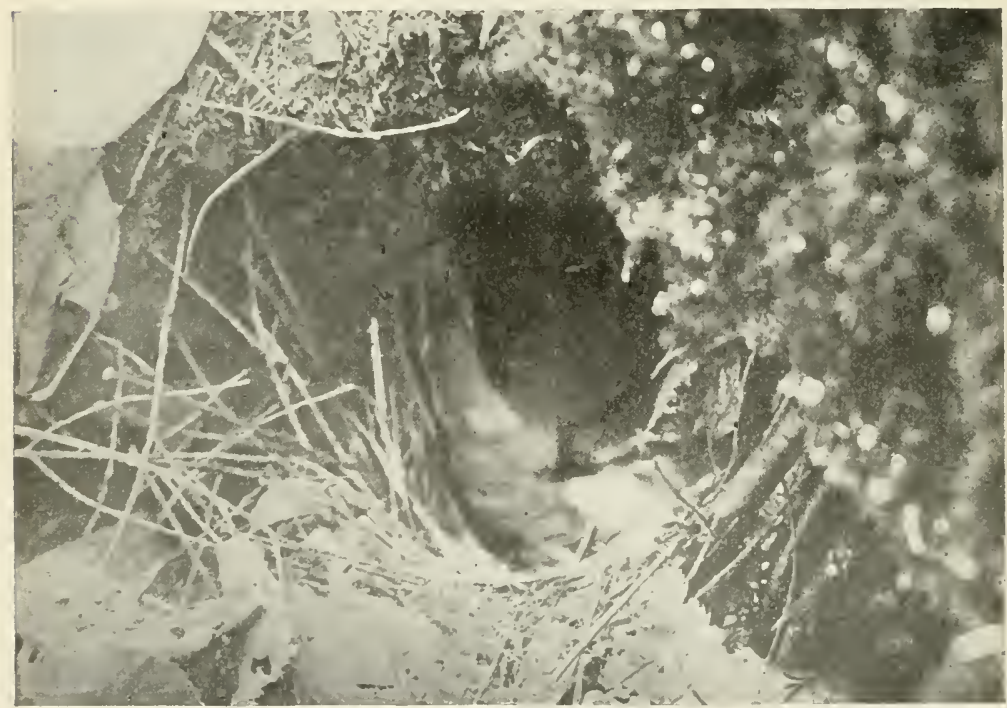

Louisiana Water 'Thrush on nest. "I'he bird stole back to the nest" (p. 욕). 


\section{FEATHERED GEMS}

reddish spots. They were cold, so I thought the bird would lay another egg, for some warblers occasionally lay six. However, I took a photograph of the nest and eggs and came back several days later, in a downpour of rain-a genuine lover of birds doesn't mind such a trifling inconvenience, if one is dressed for it. There the same five eggs were, cold and wet. I took them and the nest home and found that incubation had proceeded three or four days before the mother disappeared. I suspected the Cooper's Hawks of the murder of the female, so Ned and I went and robbed them of their eggs that there might not be four more of them there to eat warblers. It was fortunate that I identified the Nashville the first time, or I should never have known to what bird the nest belonged and the experience would have been without scientific value.

Another good warbler find I shall have to lay to the credit of my wife. Ned and I conducted a party, consisting of a bird-club of ladies, up a steep road back into the hill country where the Black-throated Blue Warblers nested quite abundantly in the woods where there was an undergrowth of mountain laurel. As two of the ladies were following an old wood road, up flitted a little olive-colored bird from close beside them, and my wife discovered the nest in the fork of a low sassafras sprout, about a foot from the ground. It was a neat, compactly woven little cup and contained four eggs. They called to me and I examined the nest and then hid, to try to see the owner. Presently she began to 


\section{FEATHERED GEMS}

hop about chirping, and I saw at once that she was of the above species from the rather conspicuous white wingbar, which is very characteristic. The male with his dark blue back and black throat is a very distinguished citizen, with a lovely little song, but his little wife is very plain indeed. This was the tenth of June, and the eggs were nearly ready to hatch.

Another season, on the twelfth of June, after climbing to examine the young "robbers of the falls," mentioned in the third chapter, Ned and I sat on the rocks below the great fall, eating our lunch. Presently I noticed a female Louisiana Water Thrush pattering about among and over the rocks, teetering as usual. At first I did not pay much attention to her, but after she had gone off and returned several times, it began to dawn upon me that we might be near her nest and that she was anxious. So we withdrew, hid behind a bowlder and watched. After climbing about for perhaps five minutes longer, the bird flew up into a recess of the steep side of the ravine, just behind where we had been eating, and disappeared. Waiting to make sure that she had settled down, we stole up cautiously, and out she popped from a hole in the mossy declivity, close beside us. There was the nest with five white, finely speckled eggs, built into the recess in the green moss and dry leaves which had lodged there. Some of these latter stuck up and partly concealed the entrance, which was five feet up from the bottom of the ravine. The owner was now running about near by, chirping excitedly. 220 


\section{FEATHERED GEMS}

After photographing the nest with the camera on the tripod, I thought I would try for a picture of the old bird on the nest. It was rather a hard problem to hide the camera properly. The only way scemed to be to tie it on the projecting rock on the side of the gully, a little above and in front of the nest. At first there seemed to be no place to stand to focus, but Ned generously offered to let me stand on his head with one foot, having the other over a rock, grasping a sapling with one hand while I adjusted the camera with the other. It was hard work and took quite a while, but at last the camera was rigged, connected by a thread, and covered with dead leaves. From over the brook we watched, till, in a quarter of an hour, the bird stole back to the nest, when I went around and pulled the thread for timed exposure, once to open the shutter, and in ten seconds to close it. In this way I exposed four plates successively, securing one picture only, as in the other cases the shutter did not work properly, closing too quickly to get an image there in the deep shadow. When we came again later to photograph the young, we were sorry to find all but one thrown out of the nest, with wounds on their bodies, and the other wounded so badly that it soon died-crows or jays this time, I suspect.

In the tall dark hemlocks around the falls, the Blackthroated Green Warblers are abundant, as they are in nearly every grove of evergreens. One can hardly listen a minute without hearing their dreamy little song 20: 


\section{FEATHERED GEMS}

which well fits in with the murmuring voices of the grove. I do not doubt but that I have walked under literally thousands of their nests, yet I never have found but one, and that was built in a pine grove near a Sharp-shinned Hawks' nest, and was deserted before the eggs were laid, the warblers, probably, being killed by the hawks. The nests are built out on the branches, usually high up, where they cannot be seen from the ground, and hence they are very hard to find, among so many thick trees. Speaking of the destruction of these various birds or their nests, according to my experience a considerable portion of the birds fail to rear their young owing to predatory vermin or cold storms. Indeed, it seems almost remarkable that any of the birds survive the many dangers to which they are exposed, and the very least we can do, in order that they may not be exterminated, is not to injure or needlessly disturb them ourselves, and, better still, to do all that we can for their protection.

Another warbler that conceals its nest in a different way is the Chat. It builds a rather bulky structure amid the densest tangle of briers, entirely hidden from sight. It was only by struggling through acres and miles of brambles, with plenty of scratches and rents in clothing, that I have found nests of this retiring bird. To hear it sing, imitating other birds and pouring forth the loud, striking medley that it does, one would expect to find it of a bold, audacious disposition, whereas it is just the opposite. So shy is it that I have 


\section{FEATHERED GEMS}

never been able to surprise or photograph one on the nest.

A very singular structure is that of the Parula Warbler. All the nests that I have found or known were built in the pendent streamers of the gray usnea moss which hangs in beards from trees. In the northern States this moss is not plentiful, and where it does occur the Parula is quite apt to colonize. I have found such colonies of a few pairs, or a dozen, in some mossgrown swamp, especially in larch or spruce trees. In one place there was an old apple orchard with trees all overgrown with streamers of this moss, and those streamers held a number of sets of eggs. The warbler does not appear to build a nest, but rather to scrape out a hollow in a swaying beard of moss and lay the eggs in this hanging basket.

I must now tell of the nesting of our common summer resident warblers, those whose nests we are most liable to come across. The one whose nest is most often found is the familiar Yellow Warbler, the kind which is practically all yellow, and which is emphatically not a wild Canary, though many people call it so. It builds a rather bulky, soft nest of plant down and fibers on a bush in a swamp, especially, in my experience, a willow bush, or near the end of a low branch of some small maple or bushy clump in the garden. A friend of mine showed me the nest of a pair in a lilac bush, right under his bedroom window. A wet bushy pasture is also a good place to search, and in such an 223 


\section{FEATHERED GEMS}

one I recently found two nests with young. I set up my camera by one, which was built only four feet from the ground, and, after decking the instrument and tripod with bushes and lying in wait a few rods off with a thread, I was able to make exposures when one or other of the parents came with food for the nestlings. One of these pictures shows the male tucking a fly into a widely opened mouth.

Another bush-nester is the familiar and interesting Chestnut-sided Warbler. This one prefers dry scrub land, brier patches, and the like. The nest is less ornate than that of the Yellow Warbler and is placed habitually lower down, seldom more than waist high, whereas the other often builds above one's head. I usually find the nest by plunging through the bushes, thrashing about at random with a switch. If I happen to pass near, the little bird flies out and there is the nest concealed from above in the foliage. Chestnut-side is a tame, confiding little fellow, an easy bird to photograph. I have set up the camera close to a nest, concealing it by drawing bushes around it and trimming it with leaves and boughs. After no more than reasonable hesitation, the pretty warbler hopped back into the nest, and, after standing there a moment to take in the situation, settled down to incubate. Then I pulled the thread and "got" my unhurt quarry. It would fly off, and when it returned I took it before it settled down. After a few such incidents, it would pay no further attention to the click of the shutter, and would 224 


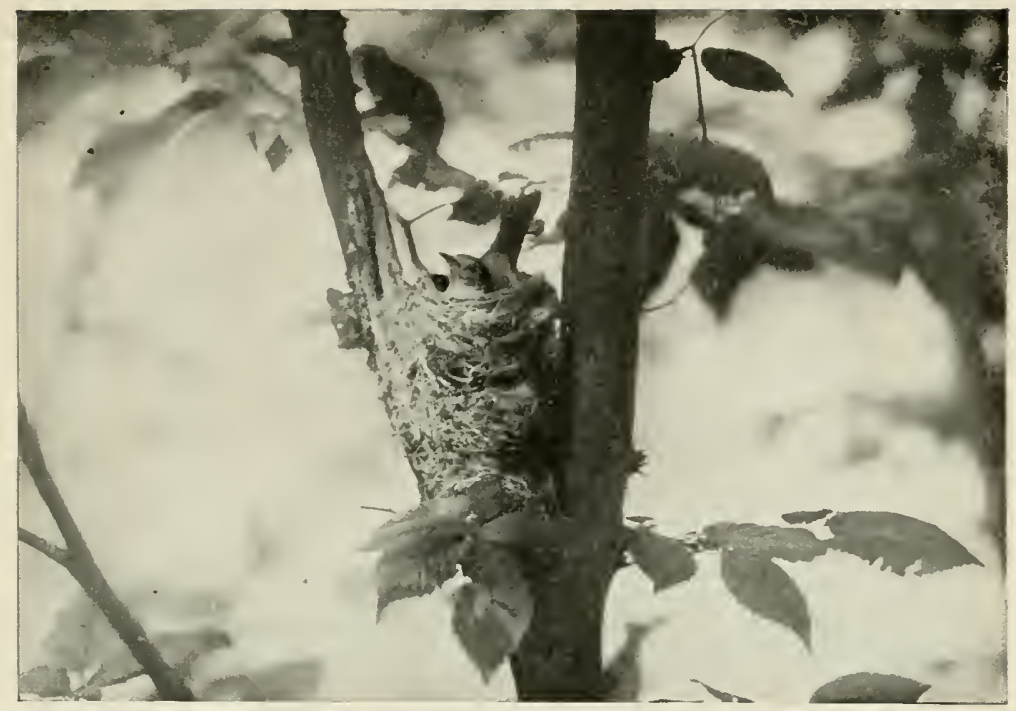

Redstart on nest. "Their home is pretty and trim" (p. 995).

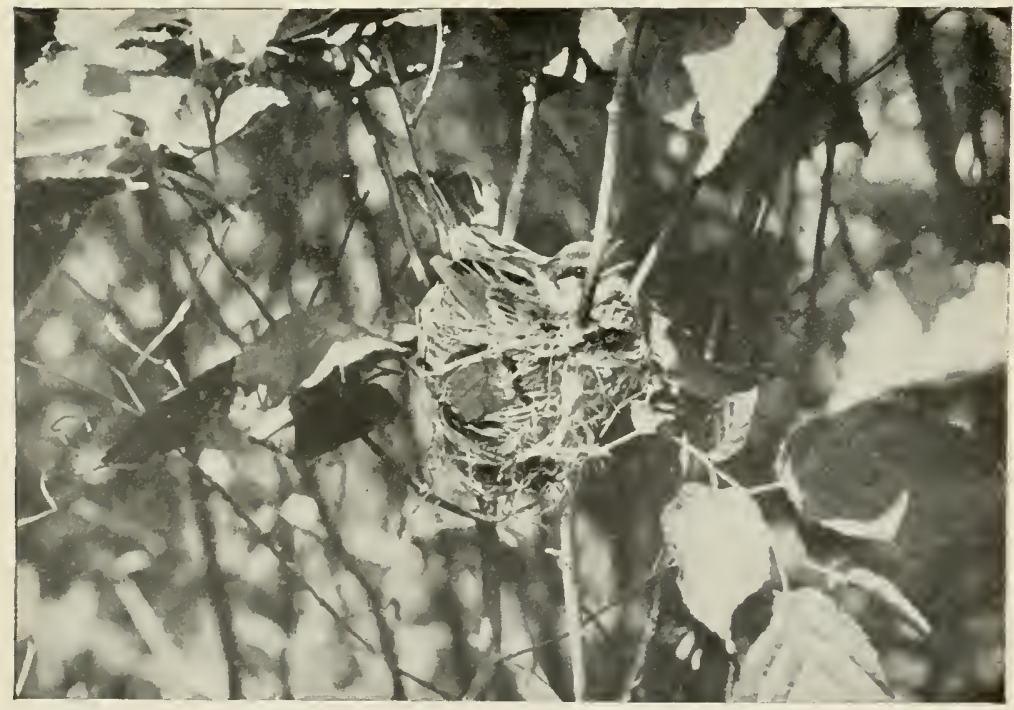

Chestnut-sided Warbler on nest. "A tame, confiding little fellow" (p. 294). 


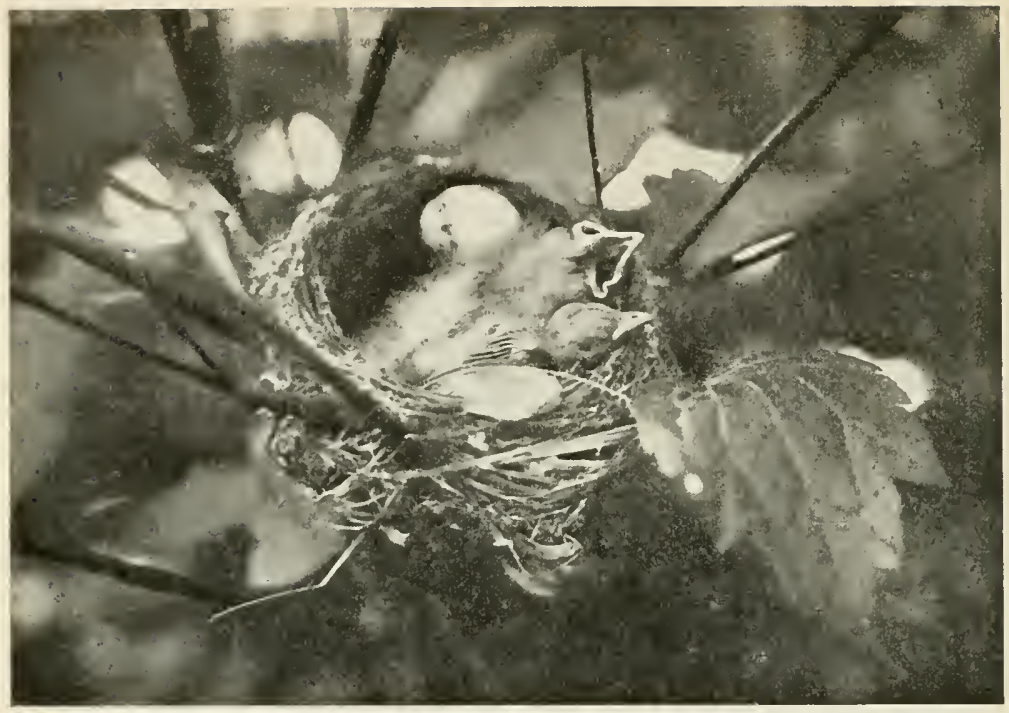

Nest of Chestuut-sided Warbler, illustrating how the young foster Cowbird destroys the brood. Nest now contains a Cowbird, a young Warbler and an egg (p. 295)

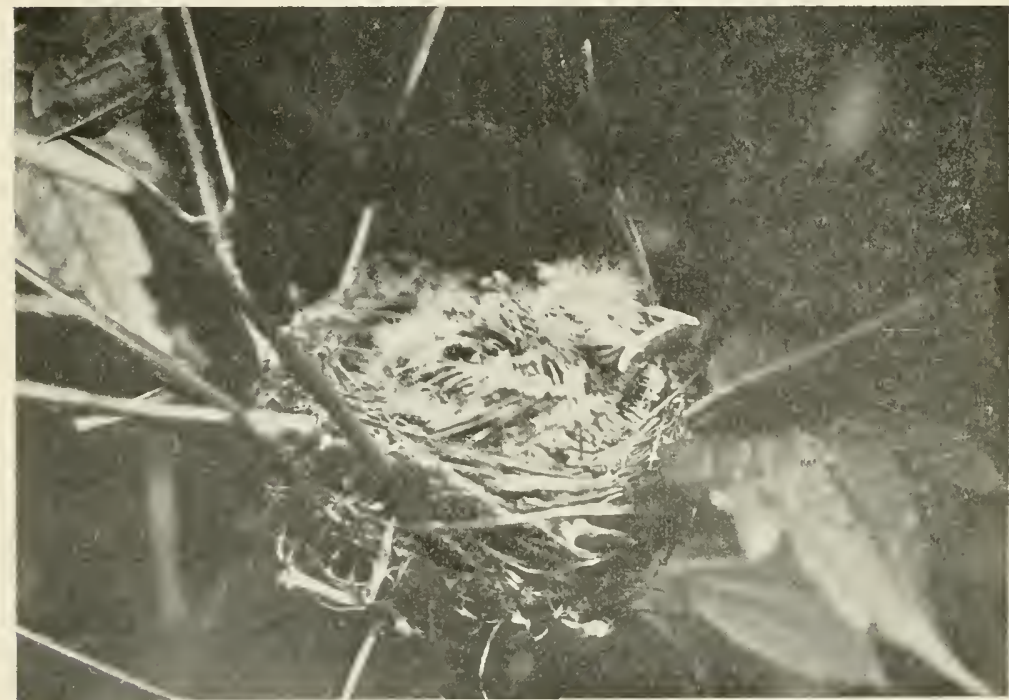

The condition of the Chestnut-sided Warbler's nest two days later. 'The young Cowbird has ejected the young Warbler, and fills the nest (p. 995). 


\section{FEATHERED GEMS}

even let me photograph it by hand and change plates without stirring.

One day, as I was driving, a boy stopped me and showed me a nest in a strip of hazel bushes by the roadside of a pair of Chestnut-sided Warblers. It contained the odd combination of a rotten egg, a young warbler and a larger young Cowbird. After some trouble I photographed the uneasy things, and, having thrown out the egg in the hope of making enough room for the ill-matched pair, returned two days later to see how affairs progressed. It was the old story. The parasite had thrown out the rightful offspring, which had disappeared, leaving the fat, ugly intruder filling the nest and clamoring for all the food that both the deluded warblers could bring. Probably this is what happens in nearly every case in which the Cowbird's egg, laid in the nest of another and smaller species, hatches.

The Redstart is surely one of the most charming of our birds. Its song is simple, but how incessantly it sings, fairly bubbling over with the joy of life-this flame of a brilliant male, whose little flame of a wife burns yellow instead of red, and who can make some music as well as he. Their home is as pretty and trim in its way as are they. It is very firmly woven into and around the fork of a sapling or of some up-sloping limb, usually from five to twenty feet from the ground, so firmly as to seem a part of the tree, and often coming through the winter storms perfectly intact, though made of rather soft material. While it is not always 


\section{FEATHERED GEMS}

hidden by foliage, it is usually quite hard to discover, so well does it harmonize with its surroundings. There was a spot in a grove where a pair of Redstarts were in evidence all the time, and I was sure there must be a nest close by. One evening I watched the female hopping uneasily about, and I peered and peeped, scanning every limb, without result. 'The next morning I went to the same spot, and the very first thing I spied her sitting on her nest five feet up a sapling in a crotch, within a few feet of where she had been the night before. I set up the camera near the nest, and she went right on again with hardly any hesitation. The shade was dense, so I got a mirror, threw light on her and the nest, and by the thread made a number of exposures, both as she sat on her four eggs and as she was coming to them.

Very hard to find are the nests of the ground-building Warblers. Indeed if it were not for flushing them by chance from their nests, the quest would be almost hopeless. The Black and White Warbler is one of these. Withal that it is so common in the woods, its nest is very hard to discover, and I have only found it twice, with eggs and with young. In the former case I flushed the female by the base of a tree in swampy woods. In the other, one June 14th, Ned and I heard the female chirping in some dry hemlock woods. We hid to watch, and presently saw her run down a trunk and disappear in the dry leaves. After a few minutes we stole up and surprised her on the nest. She went 226 


\section{FEATHERED GEMS}

out almost from under my feet, trembling her wings, as she ran stumbling over the ground. The nest was a frail affair, built partly under some dead leaves, and in it were five tiny, naked young. I withdrew for awhile, and, on returning, saw her on the nest. Proceeding to set up the camera on the shortened tripod, by working very slowly I was able to bring the lens within about three feet and focus on the little mother. It was quite dark under the hemlocks, but fortunately I carried a small pocket mirror for such purpose, and by throwing rays of light upon her was able to secure some good pictures, as she kept very still. To reward her I withdrew without flushing her from her babies.

The Oven-bird, which is so abundant in the woods, builds its nest on the ground under dead leaves which are arched over it so as to make the entrance in the side, as in an old-fashioned oven-whence the bird's name. I have been especially fortunate in stumbling across these nests, I suppose because I liave been a good deal in the woods and kept industriously in motion. One day I found two nests by flushing the birds when I had almost stepped on them. It was mid June and the eggs looked fresh. This species, and most of the warblers in this latitude, have eggs, ordinarily, by the first of June, or the last week in May, but in 1907 most of them delayed till toward the middle of June, which is very unusual. As it was toward evening and I had a long drive home, I came again, a week later. One of the nests had been robbed by some 


\section{FEATHERED GEMS}

varmint, but the other housekeeper was at home and allowed me to photograph her there, amid the low mountain laurel, as nice as you please. She left the nest when I moved the camera very near, but came back in a few minutes and then let me work and change plates without using the thread, except the first time.

The other ground-builder is the Northern Yellowthroat. It prefers a bushy swamp, with bunches of grass, in one of which latter the nest is usually placed. Not only by flushing the bird, but also by looking in tussocks when the bird began to scold, I have spied the nest. It also builds on the ground among thickets or in weeds, and on top of a skunk cabbage in a swamp it often finds a desirable location for its tenement. Such a home I once found with five eggs, and returned to it when the young were just ready to fly. Only two of them were alive, for the nest had partly tipped over and the other three had fallen out and starved or chilled within a foot of home, the parents not having had intelligence enough to help them back, feed or brood them, which they surely could have done. Just as I reached the nest the sky had become overcast. The two remaining young were determined to escape, but I tied them on a log, and, with the camera set close to them, the male came again and again and fed them. It was simply maddening that the sun would not shine out for even one instant. I secured portraits of the young by timed exposures, but the few feeding pictures that I attempted had hardly a trace of an image on the 228 


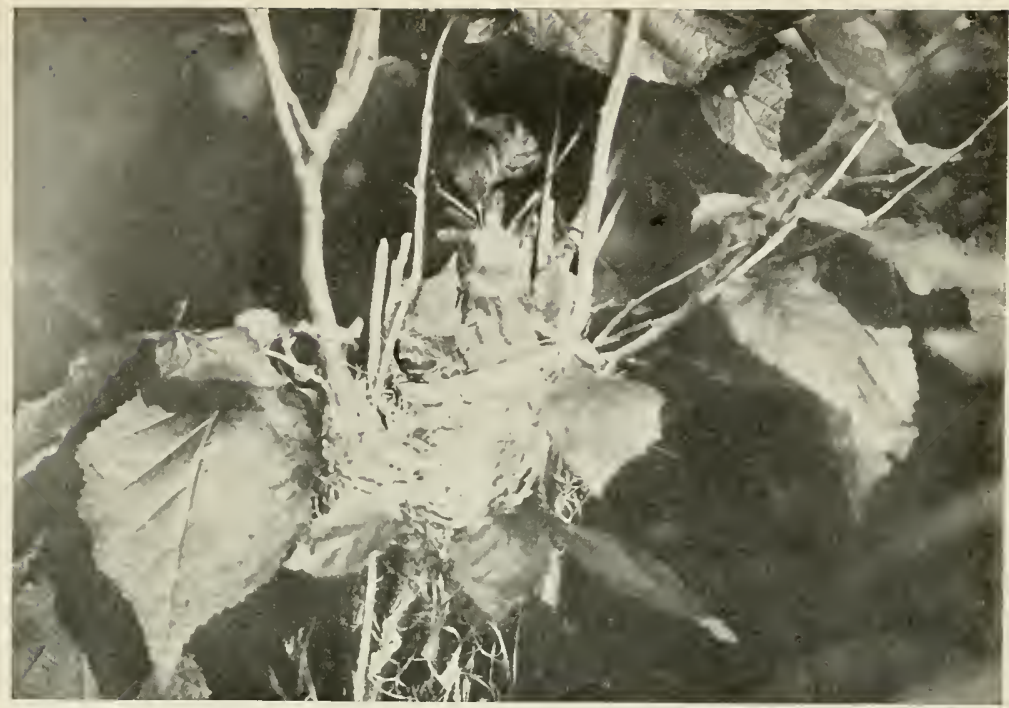

Yellow Warbler feeding young in nest. "The male tucking a fly into a widely. opened mouth" (p. 924).

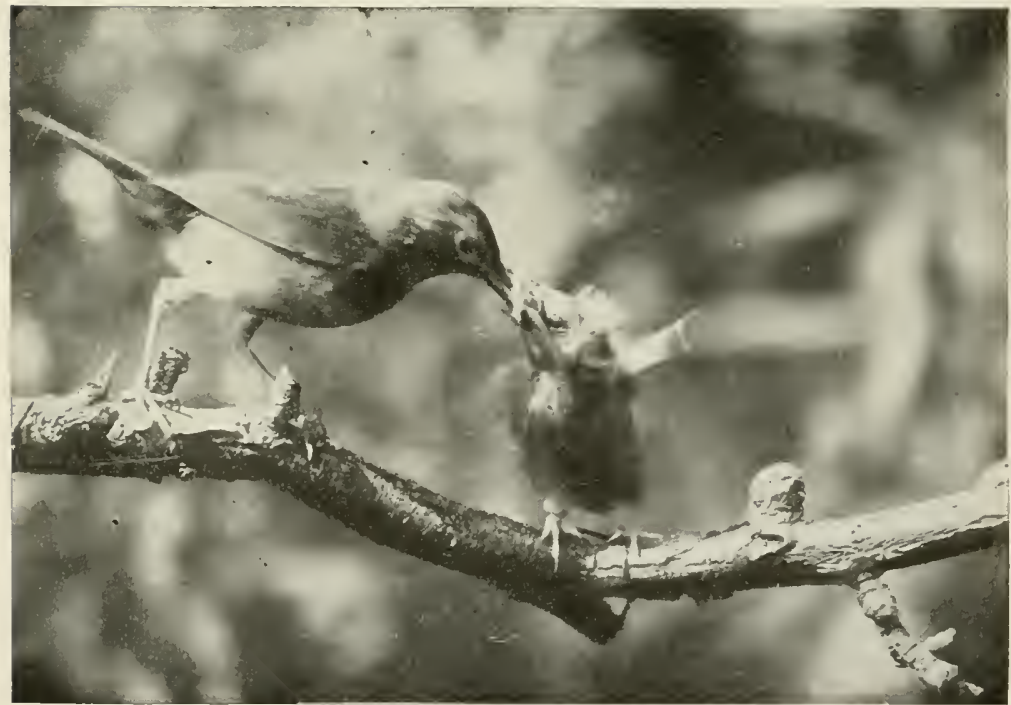

Northern Yellow-throat. "Depositing the tidbit" (p. 929). 


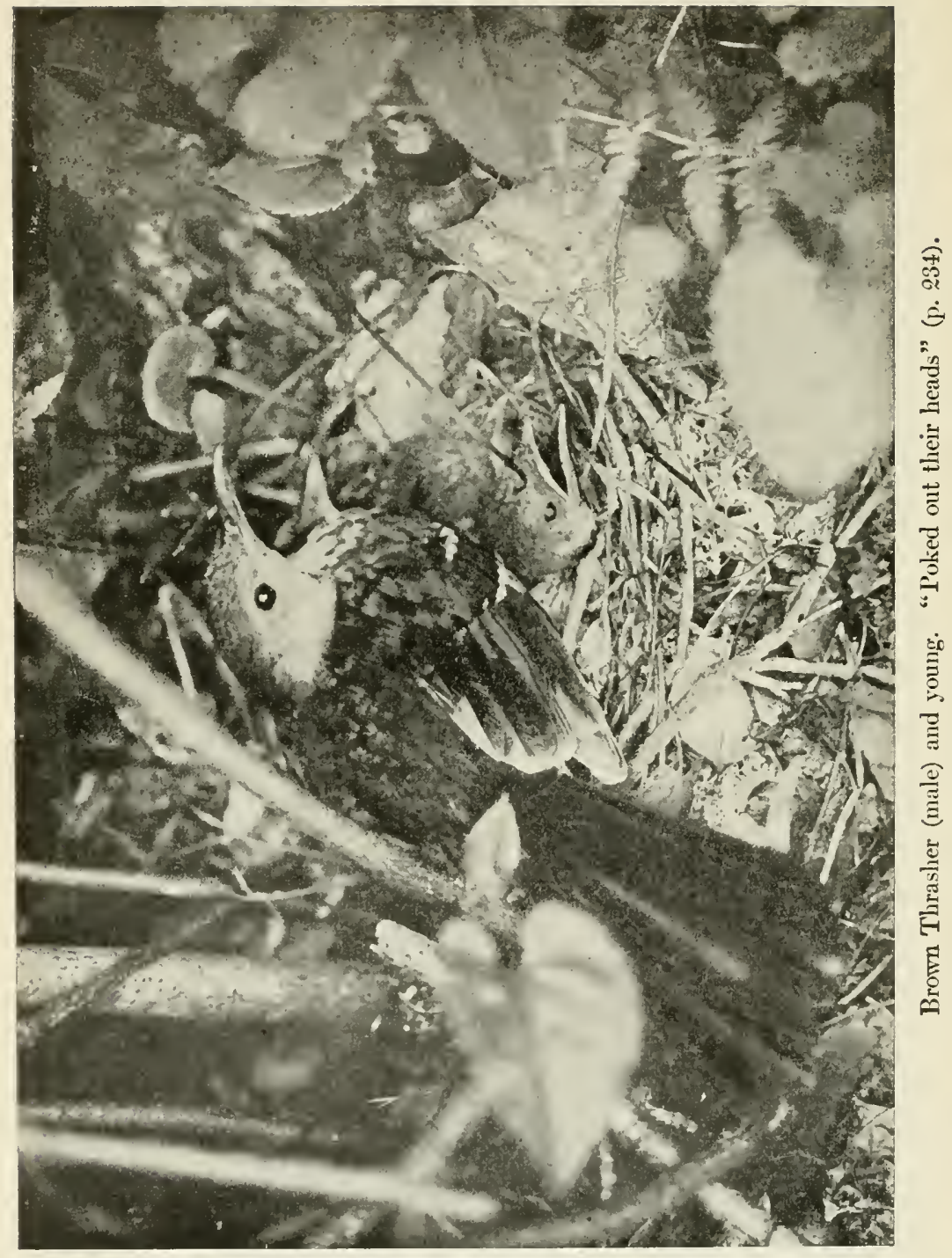




\section{FEATHERED GEMS}

plates. Next day the sun was bright, but I could not find the young, though they were near, as the anxiety of the parents proclaimed.

A year later, on the edge of a thicket by a brook flowing through a field, a pair of these birds scolded at me, appearing now and then with a worm for the young. I hid and watched and made up my mind that there were young out in the grass. After a search I found one, a fledgling, and then I knew what to do. Making a perch, I set him on it before the camera, and retired with the end of my spool of thread into the bushes out of sight. The male would not venture in this case, but the female did, and in the course of two hours she gave me sixteen pictures of herself lugging some fat worm or depositing the tidbit in the open mouth of the little bird. In another case I snapped her-though only with head and shoulder on the plate-as she was trying to ram down the youngster's throat a big harvest-fly that was altogether too large for a fit. It stuck fast, and the old bird had to come back and ram and shove before the luscious mouthful was forced down. It was the best series of feeding pictures I had ever secured and I drove home delighted with the day's work.

The American Pipit, or Titlark, is closely related to the warblers. These birds appear in flocks as rather early spring and late fall migrants, frequenting open pastures or barren ground, where they walk about jerking their tails. 


\section{CHAPTER XIV}

\section{THRUSII COUSINS}

(Thrashers, Wrens, Titmice, Kinglets, Thrushes, Etc.)

UCH a bird as the Brown Thrasher is often popularly thought of as a kind of thrush, but, though this is not strictly correct, it has so much in common with the thrushes that we can quite naturally talk of the group to which it belongs, and those between it and the thrushes in the classification, along with the true thrushes.

Our thrasher, together with the familiar Catbird and the various wrens, are classed in a family called Troglodytida, or wren-like birds. This scientific name literally means "cave-dwellers," suggesting that they are all birds of a sort of under-world, fond of seeking out holes and crevices and impenetrable tangles, sly and artful dodgers. Though willing enough to show themselves upon occasion, they seldom get very far from the possible place of refuge, into which they ean dive upon the slightest alarm. Wherever a bird of their size can penetrate, they can do likewise with their enchantments, or even go it one better.

Most people know-or at any rate ought to knowthe Brown Thrasher, the rather large bird with rich reddish-brown back and a long tail, which is so fond 230 


\section{THRUSH COUSINS}

of dusting itself in the road and which one sees flitting into the thickets. It returns from the South about the last of April, and when it mounts up on a roadside bush or sapling and pours out a flood of song, it is supposed by farmers, according to the old adage, to be calling out, "Plant corn, plant corn." The thrasher probably is no farmer, but it arrives and begins to sing at about the usual corn-planting season. It is really a remarkable songster, one of the most gifted of our feathered musicians. Toward the end of May the nest with its four or five eggs finely dotted all over with brown may be found by the sharp-eyed and persistent searcher in a thicket, either on the ground, or, more generally, several feet up in the bushes.

I used to wonder why the bird was called a thrasher. But after I had actually received a real thrashing from a pair of them, I thought I had some light upon the subject. Ordinarily they are quite timid and retiring, and, though I had heard of cases where they were very bold in defending their nests, in all my experiences I had found them as timid as most song birds. But on the afternoon of June 18, 1906, toward sundown, I was driving homeward along a country road, on one side of which was a farmhouse, on the other a bushy pasture. Here I saw a Brown Thrasher fly across the road just ahead of me, carrying in its bill a large worm. It flew down into the pasture and alighted upon the top of a dead sprout which projected from a thick clump of bushes. After pausing for a moment to look around 


\section{THRUSH COUSINS}

in order to be sure that the coast was clear, down it went into the midst of the thicket.

It was evident that there was a nest somewhere near that spot, so I hitched the horse, took my $4 \times 5$ camera and tripod, and went to investigate. First of all I made a careful inspection of the thicket into which the thrasher had gone, but could see no sign of a nest. Puzzled, I looked it through again, but with the same result. Just as I was going off, to look further away, I heard a series of sharp hissing sounds, which increased in vehemence as I followed up this clue. Even then it was some moments before I discovered the author, not a snake, but the Brown Thrasher, sitting close on a nest which was built into a cavity of the ground under the bushes. There the bird remained, though I was but a step away, looking up into my face and continuing to hiss, braving me and daring me to touch it.

Of course I withdrew a little and made ready the camera on the tripod. But the presentation of that blunderbuss was too much for the thrasher's nerves. It ran off into the bushes where it was joined by its mate, and both of them set up a great outcry. I could now see them both at times and discovered that the brighter colored one, the male, was the one which had been on the nest. No wonder they were angry and anxious, for they had five young ones, ragged and uncouth in appearance, but lusty and promising, of quite good size.

Opening up the bushes temporarily to let in a little 232 


\section{THRUSH COUSINS}

light upon this interesting subject, I set the camera upon the shortened tripod, decked it with foliage, attached a thread, set the shutter for one second exposure, and retired for awhile. The birds soon stopped scolding, so I sneaked up and discovered that the male thrasher was upon the nest. So I pulled the thread, and was glad to see that the bird sat still. He then allowed me to creep up behind the camera, change plates, and make exposures by hand, using a longfocus, eighteen inch single lens. But when I tried to push the camera nearer he beat a retreat. It was now getting too dark for further work that day, so I put back the bushes in order and went home.

Owing to trips away and rainy weather, it was not till four days later, June 22d, that I was able to resume the work, this time with a reflecting camera. Again the male was on duty. He slipped off as before, and again I opened the bushes, and, very innocently, put out my hand to the nest to remove an obstructing leaf. I was so surprised and startled that I almost fell over backward when instantly the male thrasher dashed from the shrubbery behind the nest and struck the offending hand a stinging blow. Quickly he withdrew again and took his station behind the nest with his five big offspring, waiting to see what I would do. As I was not looking for a fight, but for the pictures, I stepped back a bit and squatted, quietly waiting for the brave defender to make the next move. Though it was mid-afternoon, the June sun was quite warm, and 


\section{THRUSH COUSINS}

in a very short time the young, though now too old to be injured thus, became a bit restless. The devoted father noticed this, and came at once to their relief. Running out from his shelter, he took his stand over them, spreading out wings and tail so as to perfectly shield them from the sun. How fine and noble a bird he looked as he bravely did his duty, with an air both fearless and at the same time resigned to whaterer fate might befall him. The female was back in the thicket exhorting him, I took it, to be brare. But, despite this intrusion for the sake of my studies, I came as a friend, and would not, nor did not, hurt them.

With the reflecting camera I then advanced, and, presenting the instrument as near to him as I pleased, snapped and snapped again. Then I wanted a different pose of the brave bird, so I extended my foot toward him. Quick as a flash he pounced at my leg, struck it a quick, angry blow, and hastened back to the young, this time sitting on the nest as though incubating. After getting his picture in this position, I decoyed him off several times again. After each attack he would either return to the nest directly, or go off into the thicket a few moments before coming back home to assume some new and striking pose. One such was when he stood over the young and some of them poked out their heads to see for themselves what was going on. Sometimes, when I made only a slight feint, he would run part way to meet me and stand out in the open in a defiant attitude, while I snapped him. 


\section{THRUSH COUSINS}

During the course of this fracas the young had one by one crawled just outside the nest into the shade close by, all but one, which was more puny than the rest and could not get out of the rather deep cup. It was fortunate for me that this one stayed, for the noble parent was as ready to incur danger for one as for all. His fine example at length seemed to inspire his rather faint-hearted mate, for she began to grow more threatening and even ran out in front of the nest, where I secured just one snapshot of her standing on a low rock.

Having now used up quite a number of plates and secured pictures of about every possible position, I thought I would see what they would do if I actually handled the young. So I started to lay hold of the chick in the nest. But no sooner had I touched it than like a whirlwind, with shrieks of rage and despair, both thrashers precipitated themselves upon me. Seizing my fingers with their claws, they hung on, scratching like vixens, nipping my hand here and there with their sharp bills and beating it furiously with their wings. Then they darted off into the thicket, and again and again I tried to touch the young one, with the same result. The whole thing so touched and interested me that I felt no injury from their attack, but when I bethought myself to look at my hand I saw that it was dotted with little drops of blood, where they had scratched or bitten through the skin. Then I wrapped a handkerchief around the injured member and let them try to tear that for a change. If $\mathrm{I}$ stood up and 


\section{THRUSH COUSINS}

put my foot near the nest they attacked that, clinging to my pant leg and mauling that to the utmost of their ability.

My only lack was of an assistant to photograph the birds in the act of attacking me. It was too late, though to secure one that afternoon. The next day I would have brought Ned, but the rain poured down unceasingly, and by the day following the thrashing thrashers and their offspring had retired safely from the field of the hard fought battle and the glorious victory. No doubt they believe that they worsted and routed a man, and henceforth and forever thrasher art, folk-song and literature will, of course, prate of arms and of the man who on that memorable day backward reeled from the stubborn birds and a barren field. And, as for the man in the case, he no longer doubts the thrasher prowess, and enjoys recounting the sensations of the thrashing administered by these professional thrashers.

The melodious thrasher likes the dry thicket and patches of bushy scrub, whereas his vocal rival and near relative, the Catbird, prefers the swampy thickets, or those bordering upon wet ground. Though called Catbird from its ordinary scolding, mewing note, the bird is a really magnificent singer, with an amazingly extensive repertoire. After watching it on some perch and hearing it warble away and imitate various birds, if we invade its chosen thicket a striking change occurs as it turns from singing to scolding, about as radical as though at a concert the prima donna should suddenly 


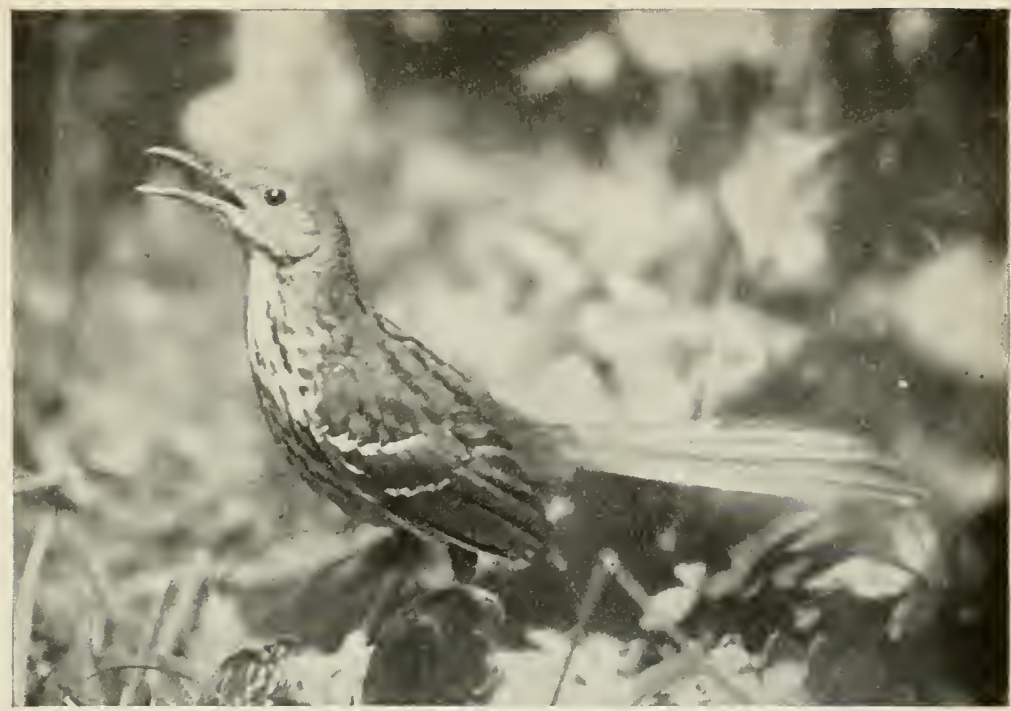

Brown Thrasher (female). "Ran out in front of the nest" (p. 235).

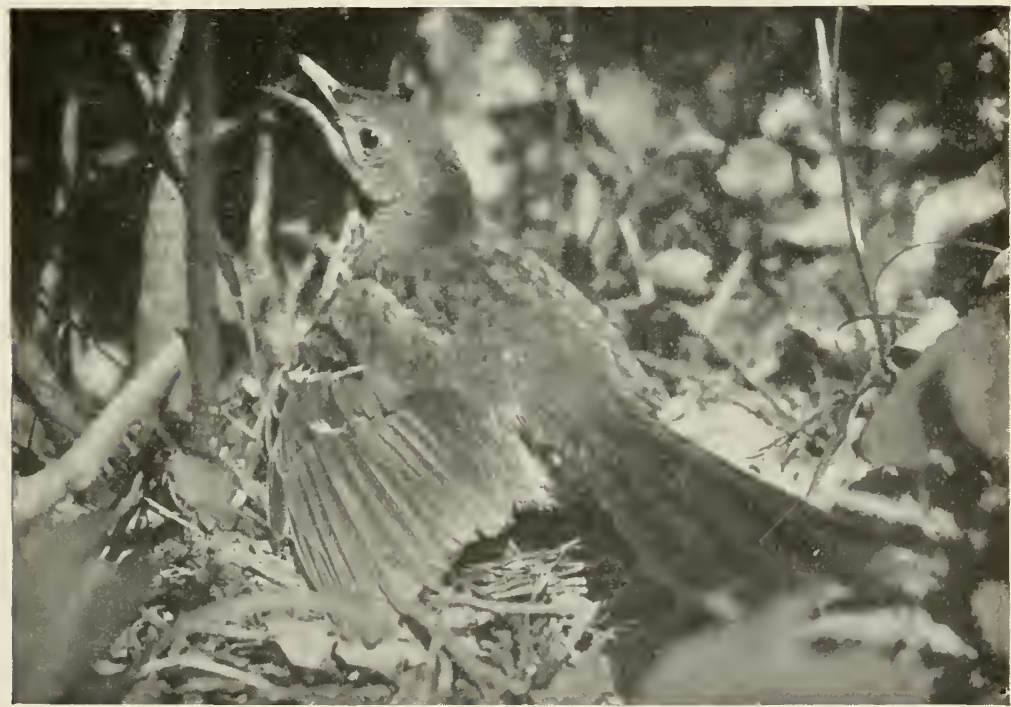

Male Brown Thrasher, shielding young in nest. "Perfectly shield them from the sun" (p. 234). 


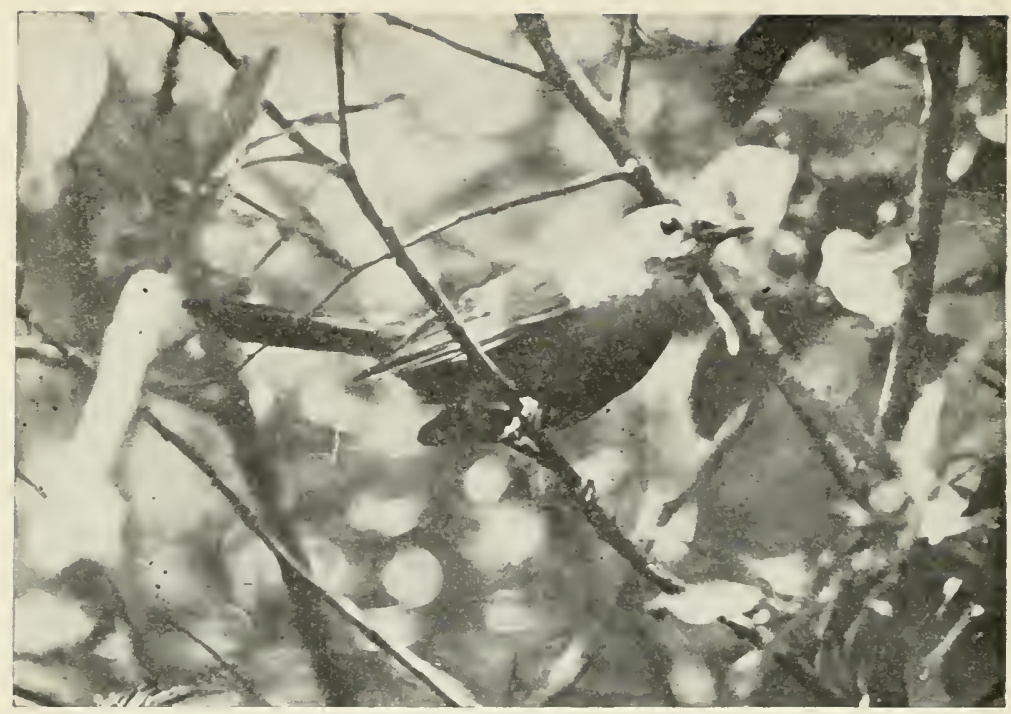

Catbird in shrubbery. "When the bird comes out for a moment" (p. 237).

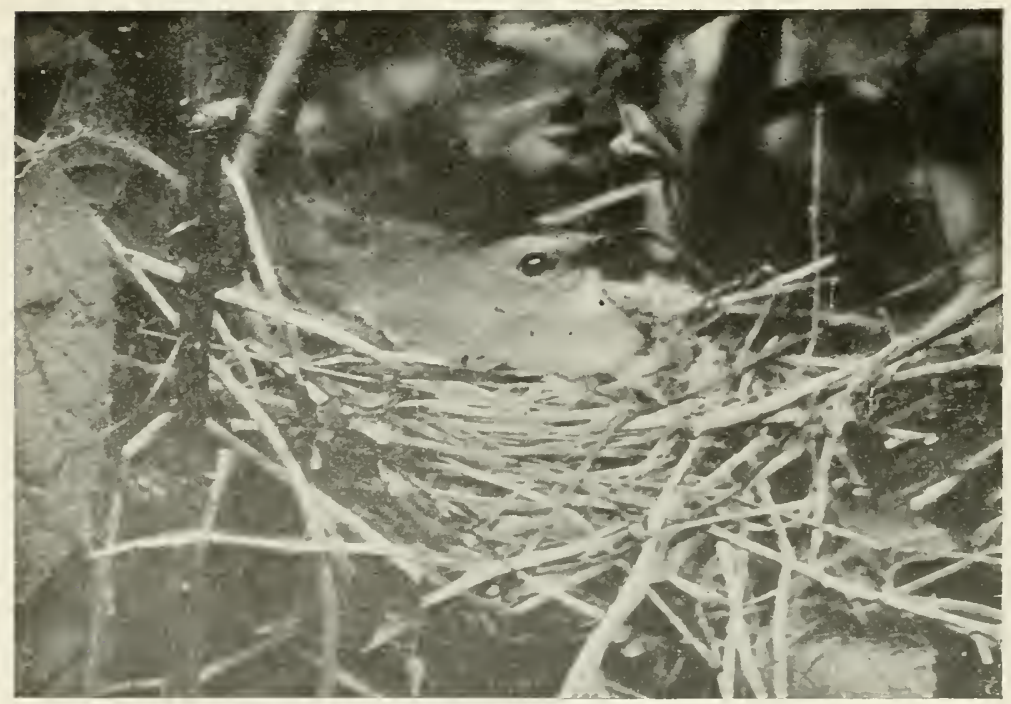

Catbird on nest. Had caught the sly fox (1. 937). 


\section{THRUSH COUSINS}

begin to swear. However we are not surprised, for we know the Catbird to be a great scold.

One will find the rather bulky nests of this bird almost everywhere in the thickets. Some are old and abandoned; the new ones, from the last of May and on, will contain four or five very dark blue eggs, and later young. When one comes near the bird flies off, and then begins to mew and scold at a great rate, yet I never heard of one turning "thrasher." For all that, though, the average Catbird is bolder then than the average Brown Thrasher. At such times I have been able to "snapshoot" them with the reflecting camera, watching the opportunity when the bird comes out for a moment upon some open branch where the sunlight strikes it. If we pose the camera near the nest, our formerly bold friend becomes very suspicious and it is no easy matter to get a photograph. At one time when I tried it, I could not for the life of me see the old bird on the nest when I crept up. The eggs were warm, and I knew she had sneaked off when she heard me coming, so I laid the thread away out into the pasture and pulled it from afar, after waiting a good long time to give her the chance to return. Twice I tried it, and in both cases, when I developed the negative, I saw that I had caught the sly fox.

The Mockingbird, celebrated for its song, belongs to the same order as Catbird and Thrasher. Though it is doubtless the best singer among them, these others are not so very far behind. It is a good deal like the 


\section{THRUSH COUSINS}

Catbird in appearance and in some of its traits. I have watched and heard it a good deal in the South, but it also comes up sparingly into the Middle States, and I have met it as far north as Boston.

And now for the most wren-like of all the Troglodytidce, for there is notling so like wrens as the wrens themselves. They all look a good deal alike, little brown fellows, artful dodgers indeed, that run into about every imaginable crevice or cranny, hunting out insects and their eggs or larvæ, surely a useful tribe. Best known of them all, and most beloved, is the House Wren. How glad we are in May to hear again the merry, bubbling song in the garden and around the house, and in due time to see the little people hunting for a building-site. Almost any sort of a hole will do, in a building, in a tree, a bird-box, an old tin can, or any crevice. As soon as they have chosen the place, they go right to work to fill it up with twigs, in the midst of which they make a soft nest of grass and feathers and the like.

Some of the sites which they select are perfectly ridiculous. I have known them to build in the pocket of a coat hung up in a shed, and in a hat or pot laid on a shelf. The funniest and most audacious thing I ever saw a bird do I am almost afraid to tell, lest I should injure my reputation for truthfulness. But, having a reliable witness, I will venture to tell it. I was off on an expedition in the West witl Dr. L. B. Bishop, of New Haven, Conn., a well-known ornithol238 


\section{THRUSH COUSINS}

ogist. In a grove by our camp he was engaged each day for about a week in skinning birds. The guide had provided him with an old upholstered chair, the lining of which hung down beneath. While the learned doctor sat doing up bird specimens in scientific form, a House Wren (of the race called Bewick's), fearless of being itself consecrated to science, actually went to work building its nest in the lining of the chair while the doctor was sitting on it, finished the structure, and before we moved camp had laid a part of her litter of eggs.

These wrens seem especially fond of an old tin can with a small hole in one end, put up for their benefit, and I have known them to set to work building within half an hour of the time the can was nailed up. Ned nailed one to an apple tree, about five feet up the trunk, and the wrens took possession and raised a brood. Every few minutes during the day they would feed the six hungry young, which gave a fine opportunity for photographs. I stood the camera boldly up on the tripod near the nest, without any attempt to conceal it, and sat a little way off holding the thread ready to pull, throwing light upon the can with a mirror. When the parent was entering or leaving I would pull the string and get a picture. After their young had gone, the pair wanted to raise a second brood, in July, and began looking around for a new site, as the old nest swarmed with bird lice. Ned nailed up another can under the eaves of a low shed, and at once the wrens went to work building in it. There they raised 


\section{THRUSH COUSINS}

the other brood, which soon became as lousy as the first had been.

If you see a wren in midwinter hopping about a brush pile or a stone wall, do not imagine it to be the familiar House Wren. It is the kind known as the Winter Wren, distinguishable from the other by having upper parts of a brighter, reddish brown. It breeds mostly well to the north, in the dark spruce forests, but Ned and I met two pairs of them in early July in a wild, mountainous part of Connecticut, whither we had gone to explore for Northern birds. How wonderfully these males did sing, a tinkling, bell-like warble, that lasted each time I should think as much as fifteen seconds, one of the longest bird songs I have heard. The larger Carolina Wren is also a famous singer. It rarely reaches New England, but appears in the Middle States, and more abundantly as we proceed southward.

We have two more wrens, very different in their habits from either of the above-the Long-billed Marsh Wren and the Short-billed Marsh Wren. These also are artful dodgers, but they do their hiding and climbing amid the reeds or grass of the marsh or meadow. Though neither of them are as gifted singers as the others, they have pleasing little ditties which add to the attractiveness of their wet surroundings. The Longbilled kind is generally much the more common and conspicuous of the two. One sees them hopping about among the reeds or rushes, tails sticking straight up in 240 


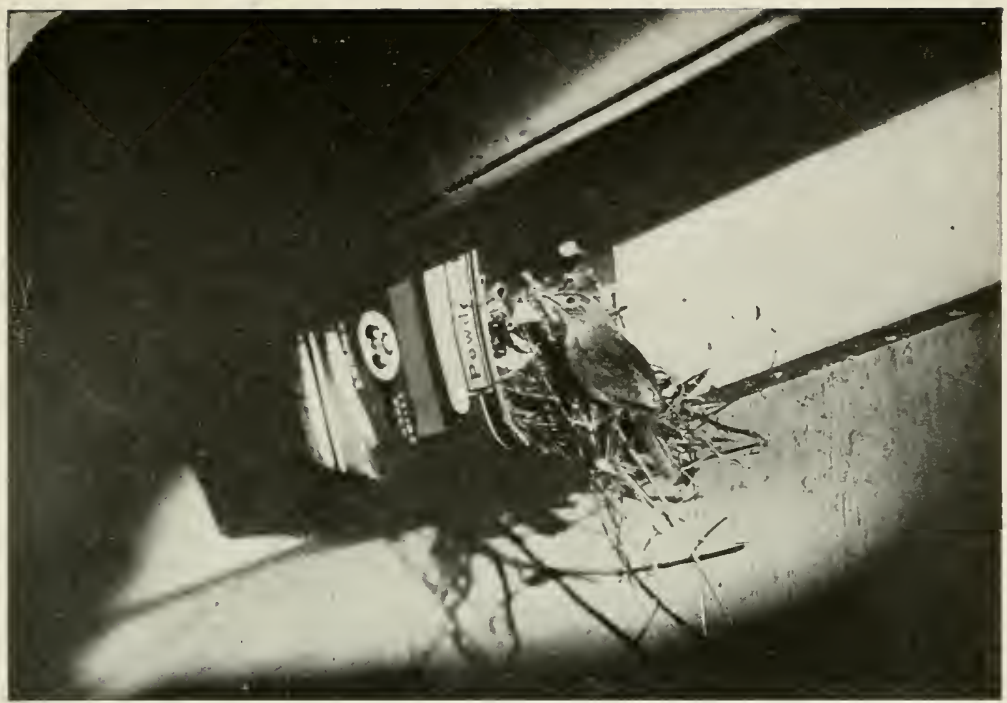

House Wren entering nest. "Another can under the eaves" (p. 939).

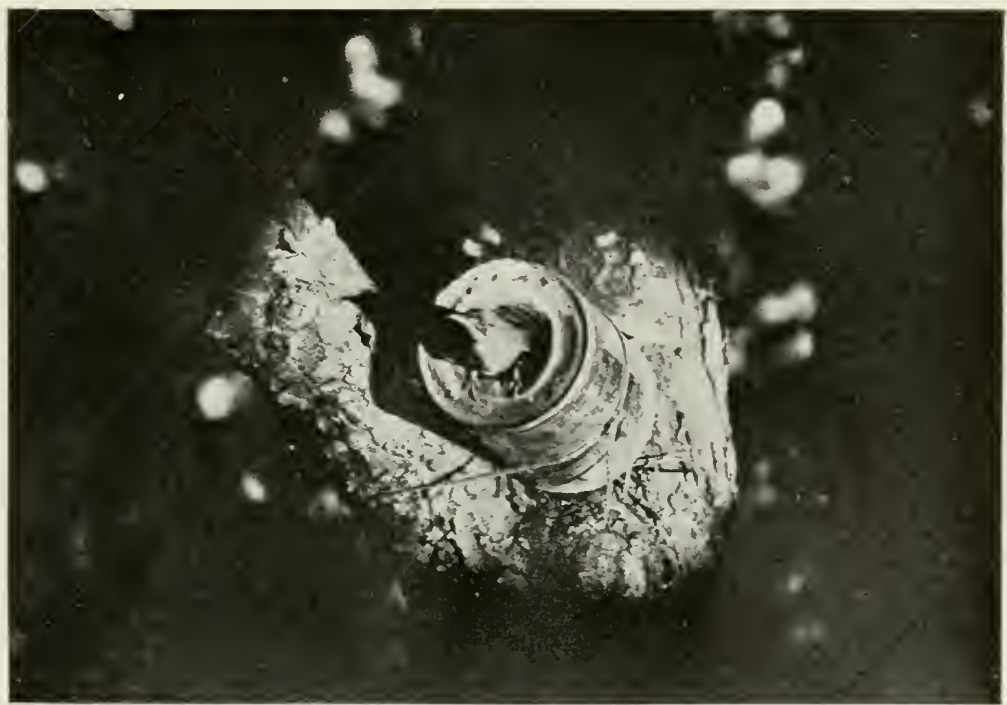

House Wren emerging from nest in old can. "Ned nailed one to an apple tree" (p. 239). 


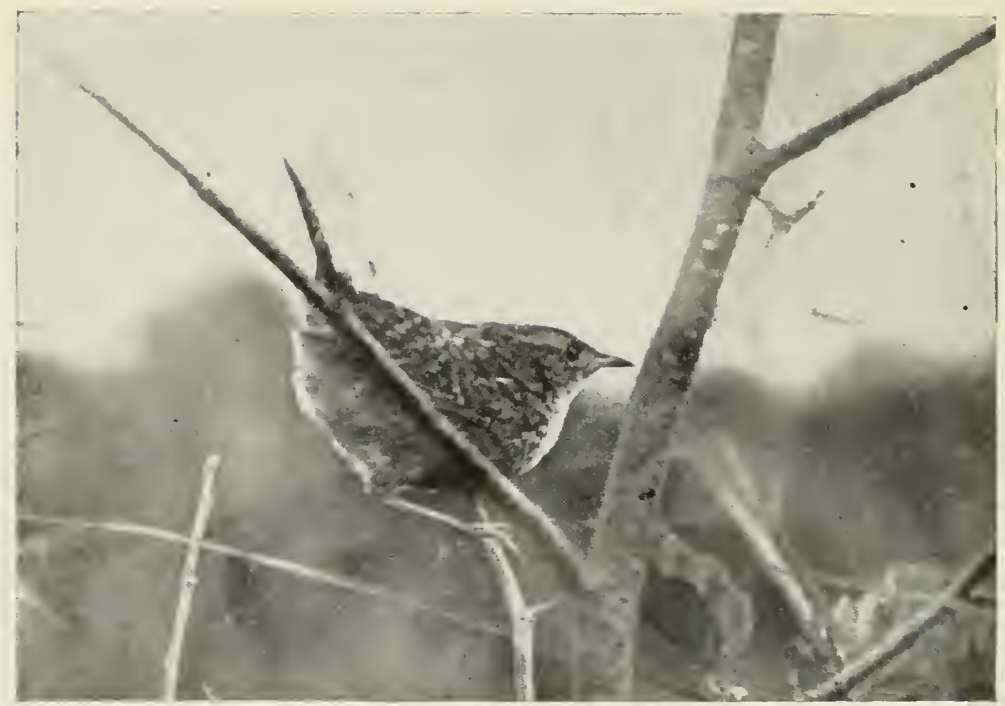

Short-billed Marsh Wren. "Alighted just where I wanted it" (p. 241).

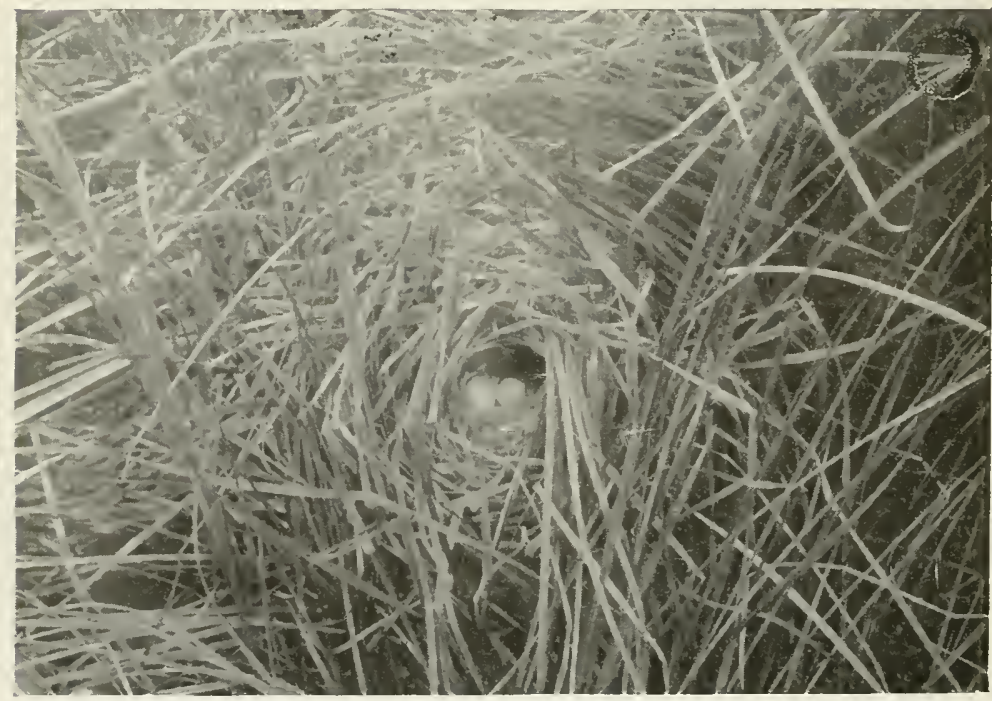

Nest of.Short-billed Marsh Wren. "Builds low down on a tussock" (p. 241) 


\section{THRUSH COUSINS}

jaunty fashion, singing away as every happy little wren should. They build a conspicuous globular nest suspended well up among the reeds or rushes. Entrance is by a little round hole in one side. The chamber is softly lined with plant down, and rather late in June contains from five to nine very dark little eggs of a mahogany-brown color. A curious trait of this wren is that it builds a number of dummy nests, apparently to mislead intruders. One will often examine half a dozen nests before the finished and occupied one is found.

The Short-billed Marsh Wren is similar in many of its habits, but is even more secretive and mouse-like than the other. It keeps more to low, thick meadow grass, and builds a nest similar to that of the other, but low down in a tussock. The equally numerous eggs are, however, pure white. The sitting bird will sneak off the nest and be hiding in the grass close by, despite all one's efforts to kick it out. I succeeded once in getting a photograph of one near its nest in a meadow by setting the camera focused on a nearby bush on which I saw it several times alight. Standing off in the distance, holding the thread connected with the shutter, I had a friend chase the little rascal. It took short flights from bush to bush, until once it alighted just where I wanted it. Often it would get just under the bush, and I would walk up and poke at it with a switch to try to make it fly up higher. But instead it would run like a mouse off into the grass. 


\section{THRUSH COUSINS}

Between the wrens and thrushes come four small groups of birds, about which we must say just a few words. One is the creeper family, of which we have but one species in America, our Brown Creeper, that slender little brownish fellow with a rather long bill and stiff spiked tail which we see in the colder months rumning up the trunks of trees, uttering faint lisping sounds as it does so. It is a timid little creature and is pretty hard to locate, even when we are hearing its deceptive notes. It usually nests well to the north, but sometimes as far south as southern New England, and builds behind a loose, rotten sheath of bark on a decaying tree.

Next are the nuthatches, two of which we haveWhite-breasted and Red-breasted Nuthatches. Their name was earned by skill in cracking nuts. They are the funny little blue-gray fellows that climb about on the trees saying, "ank, ank," hanging or feeding head down as easily as any other way. The smaller Redbreast we have mostly as a migrant to and from the North, but now and then it stays in winter. The Whitebreast we have resident with us the year round. In winter it becomes very familiar and accepts our hospitality of nuts, crumbs, or suet. It is not a bit afraid of the camera, and many a person, myself for one, have photographed it by focusing the camera upon the "lunch counter" and pulling the thread when the bird seems to be posing just right. Some use a pneumatic tube and bulb, but this derice cracks and leaks air or 242 


\section{THRUSH COUSINS}

fails to move the shutter, and I very much prefer a thread. Quite early in spring friend Nutty ignores our charity and makes a nest in a hollow limb of some shade or orchard tree, where it raises a family of from five to eight.

The sub-family of titmice are now classed with the nuthatch sub-family in the family Parido, or titmice, and well so, for they all have much in common in their mode of life.

Our common little Chickadee is enough to make us think well of this group. They are so animated and interesting that it is a delight to have them about our homes in the winter, feeding on the suet. Everyone ought to tie or nail up a piece of fat meat for the birds, out of reach of cats, and as an investment it pays big dividends in the pleasure which their company in the long, cold season affords. Like the nuthatch they are easy to photograph, and like them they forsake us with the passing of the snow, and, betaking themselves to the woods and swamps, in May they excavate a tiny burrow in a rotten stub, in my experience generally a birch, which is very soft. Like the nuthatches also they rear large families, and it is remarkable how the young birds escape being smothered, for they fill the hole about solid full when they are well grown. If we take them out it is a real problem how to get them all in again.

Toward the end of winter the Chickadee has a fine trick of fooling people by a note which they think is 243 


\section{THRUSH COUSINS}

made by the Phobe. It is a long-drawn, plaintive whistle- "pee-wee-e," but it is not so very much like the Phœbe's note, if one could hear both together. Yet the correspondent of the local country paper reports the first Phobe heard-though never seen!-in January or February, and the knowing ones smile. In Canada there is also the Hudsonian Chickadee, which wears a brown cap instead of a black one, and says "dee-dee" instead of "chicka-dee-dee," and in the Middle States and southward they have the Tufted Titmouse, which has a topknot, and the Carolina Chickadee.

In still another group, the Sylviida, or birds of the "Old World Warbler" type, we have several dainty little midgets, next in size to the hummers, which are very interesting. One is the Blue-gray Gnatcatcher, found in the Middle States and southward. I have had no opportunity to know and study it afield, as I have the two other species, the Kinglets-Golden-crowned and Ruby-crowned. They are both tiny birds, greenish olive above and white beneath, with a brilliant crown color-patch which the Manuals describe, which, however, is lacking in the female and immature Rubycrown. They are spring and fall migrants with us, sometimes wintering. How such fragile little mites of birds can keep from freezing in cold weather is a mystery. They are fond especially of evergreen woods, but appear in other timber as well. If in the woods one hears repeated faint lisping sounds which are hard to locate in the treetops, they probably are made either 244 


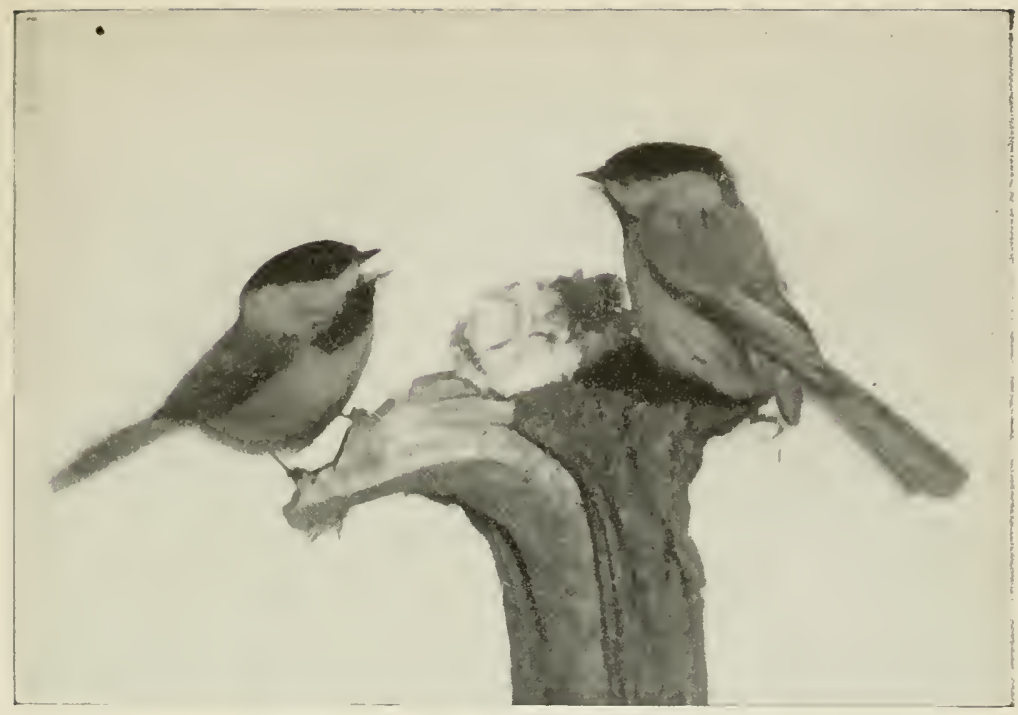

Chickadees. "Feeding on the suet" (p. 943).

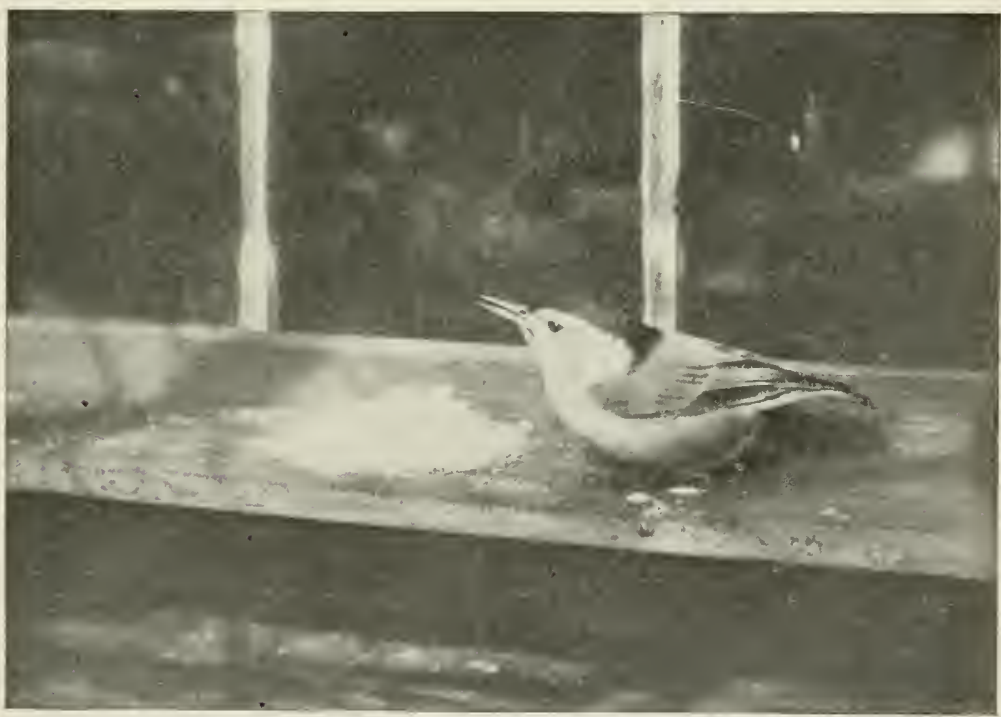

White-breasted Nuthatch. "Accepts our hospitality" (p. 242). 

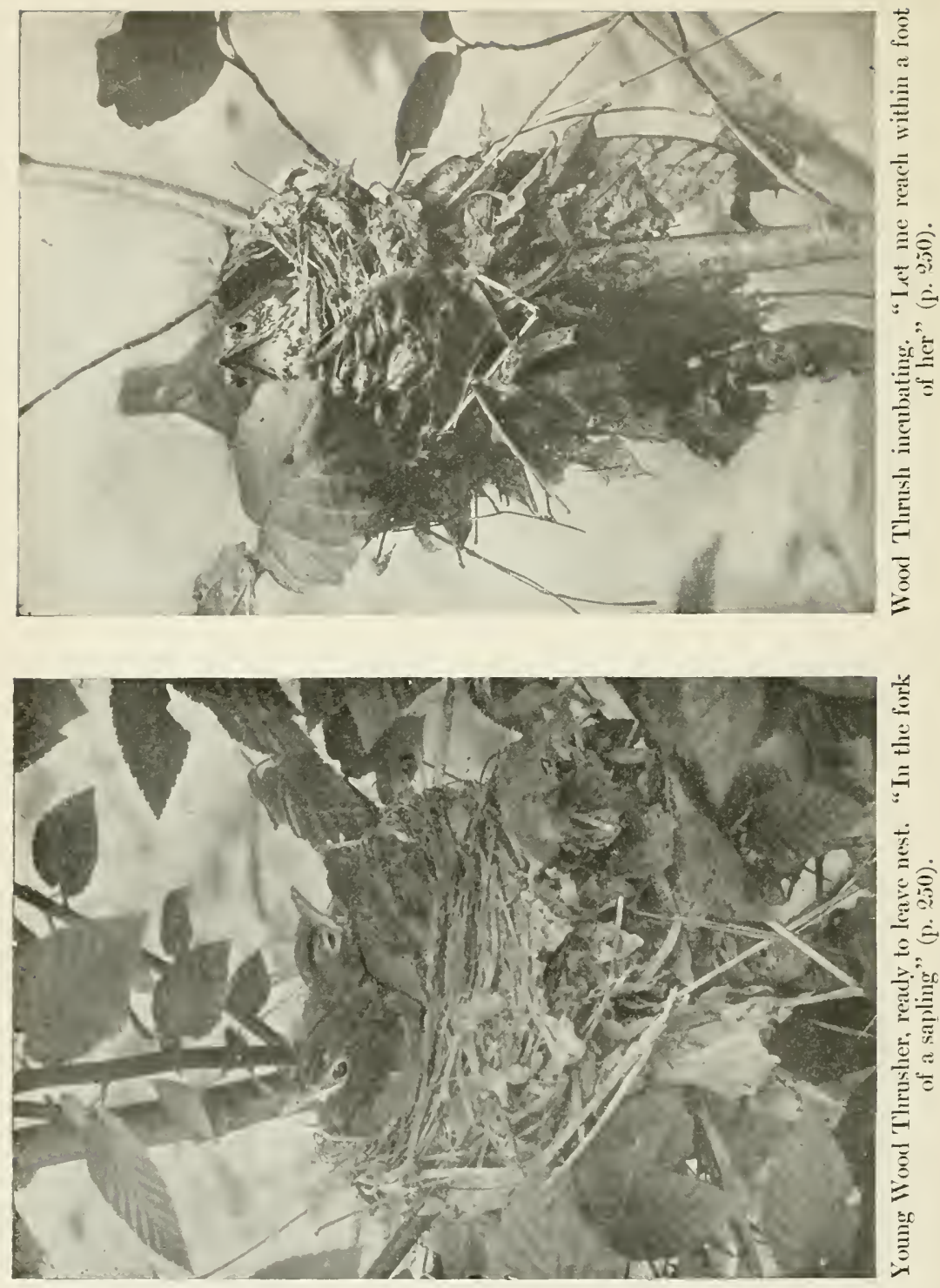


\section{THRUSH COUSINS}

by the Brown Creeper while running up some trunk and hiding behind it, or else by either or both of these Kinglets. They go in small parties, sometimes the two species together, and often in company with the Chickadees, flitting merrily from branch to branch in their hunt for larvæ, lisping away in their almost insect-like dialect. In northern New England and Canada they build globular nests of moss, with side entrance, suspended well out on the limbs of evergreens in the forests.

Now we come to the thrushes, another of our rather puzzling groups, though they are not as hard to master as the finches or warblers in that we have not nearly so many species of them. In the Eastern and Middle districts of the United Siates and Canada there are but eight species and forms to learn, and most of these are perfectly distinct, some of them very well known. For instance, no one can mistake the Robin or the Bluebird-these are both thrushes. Then there is the familiar IVood Thrush, the bird with bright reddishbrown upper parts and heavily spotted breast. The common Veery, or Wilson's 'Thrush, has also bright upper parts, though less so than the preceding, but smaller and fainter markings below. The Hermit Thrush has a bright rufous tail, much brighter than the brown of the back. The only great confusion can occur with the darli-backed thrushes, which are the Olive-backed and Alice's-the latter having under it another form or geographical race known as Bicknell's 245 


\section{THRUSH COUSINS}

Thrush, the only difference being that it averages a little brighter and smaller than the Alice's Thrush. Both these two species have upper parts dark olive brown and light but spotted under-parts; they differ mainly in that the Alice's Thrush has the light color of the under-parts, throat, sides of head, and eye-ring, pure white, while in the Olive-backed Thrush these parts have a buffy suffusion.

If the bird student can bear these points of the thrushes in mind, there will be little trouble in identifying them, if one can only get a good view of the birds. But, "aye, there's the rub." The thrushes, all except the Robin and Bluebird, are timid, retiring creatures, fond of deep woods or swampy woodland solitudes. The latter are especially the Veery's choice, and we can oftener hear than see him, as he utters his ordinary "whee-u" call, or chants his simple "veery-veery-vecry" lay. All the thrushes are good singers, with flute-like tones, and more continuous and elaborate songs than most birds. The Hermit Thrush is the finest singer of them all, with the IVood Thrush as a close second, and honorable mention for the efforts of the Olivebacked and Alice's Thrushes. The Robin's familiar outpourings have a homely beauty and strike a responsive chord in all hearts, while few sounds of Nature delight us more than the ethereal xolian harp of the Bluebird, especially as heard from the skies in March mingling with the sighing of the cool northwest wind-our harbinger of spring. 


\section{THRUSH COUSINS}

The Bluebird is usually the first thrush to arrive, followed soon, or even accompanied, by the Robin. The next to come is the hardy Hermit Thrush during the first half of April. We find it searching for larvæ among the dead leaves in the woods, and sometimes I have met it when Ned and I were gathering the first blossoms of the ever-welcome trailing arbutus. Early in spring, it is also late in fall, and it appears mostly as a migrant, though I have found it as far south as Connecticut in the breeding season in high mountainous wooded regions. The Wood Thrush comes rather late in April, followed by the Veery in early May, and both of these beautiful species remain with us to breed. About the middle of May the Olive-backed and Alice's Thrushes usually appear, in the height of the warbler migration, soon to pass us by for the silent northern spruce forests.

The Bluebird is the first of the group to go to nesting. Early in April they begin to build in the bird-box, or the hollow limb or woodpecker's hole in the orchard, by the roadside, or in swamp or pasture. By the tenth of the month some pairs have their five pale blue eggs. Ordinarily they raise at least two broods, and it is August before all of them are through with these household cares. Then they gather into flocks and have a good easy time here till they leave us in November. It is pleasant to have them nest on our premises, and it is well worth while to put up boxes for their use. The surest form of architecture to attract them is a 


\section{THRUSH COUSINS}

section of a hollow limb, closed except for one quite small hole in the side, and nailed upright in a tree.

Soon after the Bluebird, the Robins get busy with housekeeping, from April 20th and on. Everyone is familiar with their operations, and knows of the curious sites which they select for nests. In my garden and premises a pair has built on the piazza in the woodbine, another on a branch extending over the front walk, and two pairs close together at the same time in a shed. They are fond of the apple orchard, and a hole in a bank by the roadside is quite attractive. One foolish pair built flat on the ground by a roadside under a projection of turf, and a kindly neighbor had to put some branches in front of it to keep away cats. The mother bird was so shy that she would hop out whenever anyone passed by, but for a wonder she raised her brood of three. This is the usual number for the second brood, but it is generally four for the first, and very rarely five. I only remember seeing three nests with five eggs, out of the many hundreds I have examined. Once Ned put his hand into a Robin's nest to see what was in it and broke an egg, the only time I ever knew him to have such a mishap. When he looked in, he saw that it was a rare set of five. However, the bird still had the usual number!

Since the Robin builds so near houses it is easy and interesting to watch the family life. One of the prettiest sights in bird life, I think, is to see the mother Robin, on a rainy day, stand in the nest and spread out her 248 


\section{THRUSH COUSINS}

wings over the youngsters like an umbrella, thus keeping them dry, despite the downpour.

The Veery generally builds on the ground in the woods, among shrubbery, or very near mother earth in a clump of low bushes. Generally it is not easy to find the nest except by flushing the brooding bird from it, but in this way I have often found nests and photographed them. The Veery will let one come quite close before leaving, and I have tried to snap her by walking up with the camera in hand, but she could not quite muster up courage to wait for me. Sometime, when I get round to it, I imagine it will not be so very hard to get a picture by setting the camera. I had a good chance this last season and would have tried it, had not some bad boys broken up the nest. It was on the edge of a little wood road quite near home, in some low weeds, about a foot from the ground, right in plain sight of any passer-by. It is strange what pleasure anyone can find in destroying a bird's home and eggs without purpose, not even for collecting, but just in wanton destruction. How infinitely much more real fun it would be to watch this family from the first to the time when the young were grown-seeing when each egg was laid, how long it took to hatch, how the parents fed the young, how long it took them to grow up, how they left the nest, and so on. But to destroy a bird's nest "for the fun of it" is lower than brutish, for even a "rascal" crow or jay robs nests for food.

The nest of the Wood Thrush is generally built in 249 


\section{THRUSH COUSINS}

the fork of a sapling or low tree in the woods, from four to eight feet up. It is quite bulky, stiffened with mud like the Robin's nest, and the three to five blue eggs look almost exactly like the eggs of that bird. The dead leaves of which the foundation for the nest is usually made, though, "give it away," as to identity. The incubating Wood Thrush varies individually as to tameness, but generally it will allow a near, and sometimes a close approach. Several times I have been able to place my tripod and camera very near a nest and take pictures without flushing the birds, but only because I made every motion very slowly and carefully, taking a long time to do the work. On one such occasion Ned watched me, and thought it looked easy, but when he tried it, away went the bird, simply because he was in too much of a hurry. In such work with timid birds, after every new movement one must pause for the bird to become accustomed to that condition, ere it is ready for the next innovation. One mother Wood Thrush was so obliging that she let me reach within one foot of her and bend aside leaves without being startled to flight. But the next time I went, when she had young, I could not get within fifteen yards of her. The best rule in working with birds is to take advantage of their varying moods, and when a bird is "nice," use the present opportunity for all it is worth, as though there would never be another, for, indeed, very likely there never will be just such another again. 


\section{CHAPTER XV}

WATER-BIRD WAIFS

\section{(Wading and Swimming Birds)}

THE water-birds as a class, both waders and swimmers, though often neglected by bird students, to me seem exceedingly fascinating, as much so as any other group of birds, if not even more. This may be because I am almost a sort of water-bird myself. I have a fellow-feeling for the ducks because I swim, and for the white-winged gulls because for years I have loved to spread the white yacht sails to the breeze and skim over the brine. And as for the wading-birds, the mysteries of swamp and morass make strong appeal to my imagination, and I love to wade and scramble about and enjoy the free unconventionality of the realm where land and water intermingle. Such things, too, appeal to a boy like Ned, as they are bound to appeal to any lively boy. I think and hope that I must still be a boy, and I mean to be one as long as I live.

One great trouble in studying the water-birds is their general scarcity. No matter how shy and retiring they are, if they only were somewhere, I would risk the 251 


\section{WATER-BIRD WAIFS}

enthusiast's ability to get in touch with them. But no one can see a thing which does not exist. Birds of this class are large enough to be conspicuous, and some of them are good to eat, and both these facts have served to invite persecution from gunners. So it is a lamentable fact that most of the wading or swimming birds, certainly in inland localities, can seldom be seen. You cannot walk out any day and say you will watch ducks, herons, or shore-birds. Unless you know a spot where some one pair or species breeds, you might go forth dozens of times and not see one solitary water-bird. Some time, we hope, there may be better conditions, as public sentiment is being aroused against the wanton extermination of our beautiful wild bird-life, and many excellent laws are being enacted and enforced.

It would make this book too large if I were to go into full accounts of the wading and swimming birds, so I must simply and briefly mention the birds of this class which may be found in any typical inland country town, and refer my readers to my other books where I describe these birds and their ways, both in text and in photographs. "Among the Water-Fowl" deals with the swimming-birds, both of the ocean and of inland waters. Additional studies of these are given in "Wild Wings" with extended accounts of the shorebirds, besides other material. The system of classification now accepted begins with our lowest order of birds, nearest to reptiles and fishes, the grebes, and works up to the highest, the thrushes. In this book we 


\section{WATER-BIRD WAIFS}

started in part way up the scale, with the gallinaceous birds, so now we will work backward thence to the beginning.

The first group to mention in this plan is the shorebirds, and of these, unfortunately, there are now few, indeed, that visit our inland towns. A century or less ago, for instance, almost every barnyard had its Kildeers (plovers), and every field its Upland Plovers (Bartramian Sandpipers). But to-day they are gone, save in rare instances. Great flocks of the beautiful Golden Plover used to descend upon the fields in their southward flight in late August and September, but now they are all but extinct. 'Too bad, too bad! Along the shores of the larger ponds or lakes we may occasionally see a few Semipalmated Plovers, or Ringnecks, occasional Least and Semipalmated Sandpipers, perhaps in small flocks, and the Greater and Lesser Yellow-legs on shores or in meadows. The time for any of these is August and September, and for the Greater Yellow-legs even October.

The only shore-bird which breeds is the Spotted Sandpiper, the little bird popularly called "Teeter," which runs along the margin of pond or river, teetering its body up and down in nervous fashion. Medical authorities decry our "teetering" with the rocking chair as conducive to nervous disorders, but this little chap teeters all his life and does not appear to suffer for it. Possibly it might add fifty per cent. to his years if we could teach him to calm himself and "be aisy!" 


\section{WATER-BIRD WAIFS}

By early June each sandpiper pair has scratched a little hollow, lined it with a few straws, and laid four pointed, heavily spotted eggs. The mother flutters and limps away when you surprise her upon them, and is even more solicitous when they have hatched and the odd little chicks are hiding from you, squatted flat on the ground, where it is very hard to see them.

One day Ned and his mother were walking along the river bank, following a cart road, when away fluttered a Spotted Sandpiper, and there, just beside the road, under some weeds, was the nest with the usual four eggs. Of course I had to go and see it, and Ned very proudly brought me to the find. Off went the anxious bird, and I could then see her running along the pebbly river margin, saying "peet-weet, peet-weet." After setting the camera on the ground near by, with some rocks piled over it, we hid in the bushes and watched for the bird's return, ready to pull the thread. We had been quiet for only a few minutes when she came cautiously walking back, teetering almost constantly. She went right past the camera without noticing it, then to her nest, and settled down, poking and arranging the eggs with her bill. At the snap of the shutter she darted off. I set it again, and she soon came back. After securing several pictures, we ment away and left her in peace. This nest was located, as is generally the case, near open water, but quite often a mere brook will suffice, and not infrequently the location is 


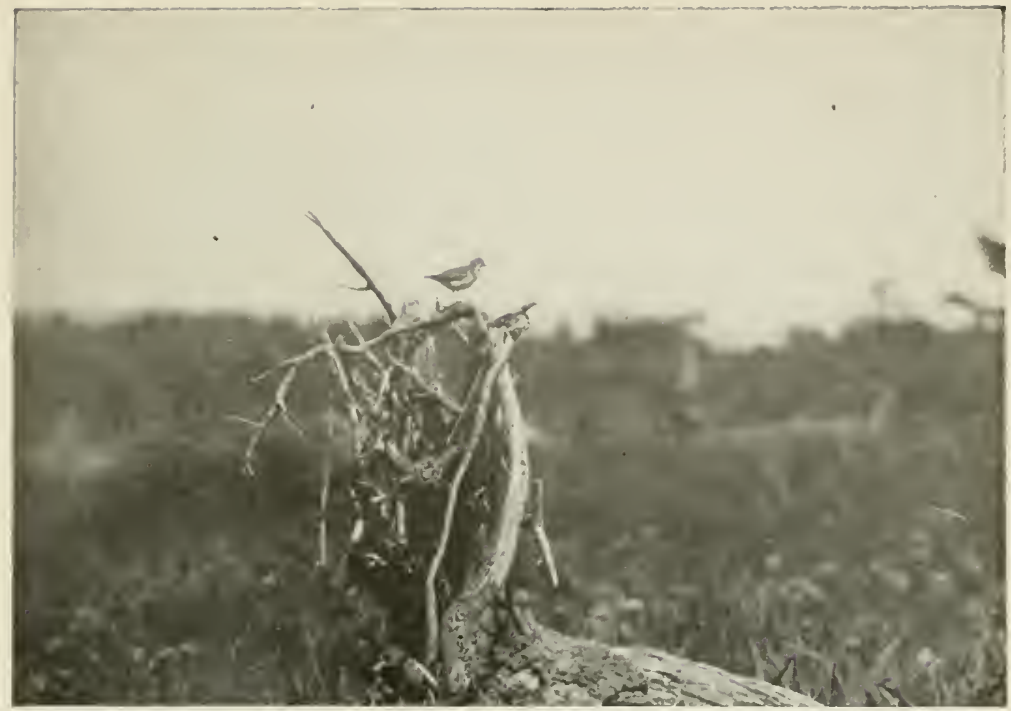

Spotted Sandpiper scolding "Even more solicitous when they have hatched" (p. 254).

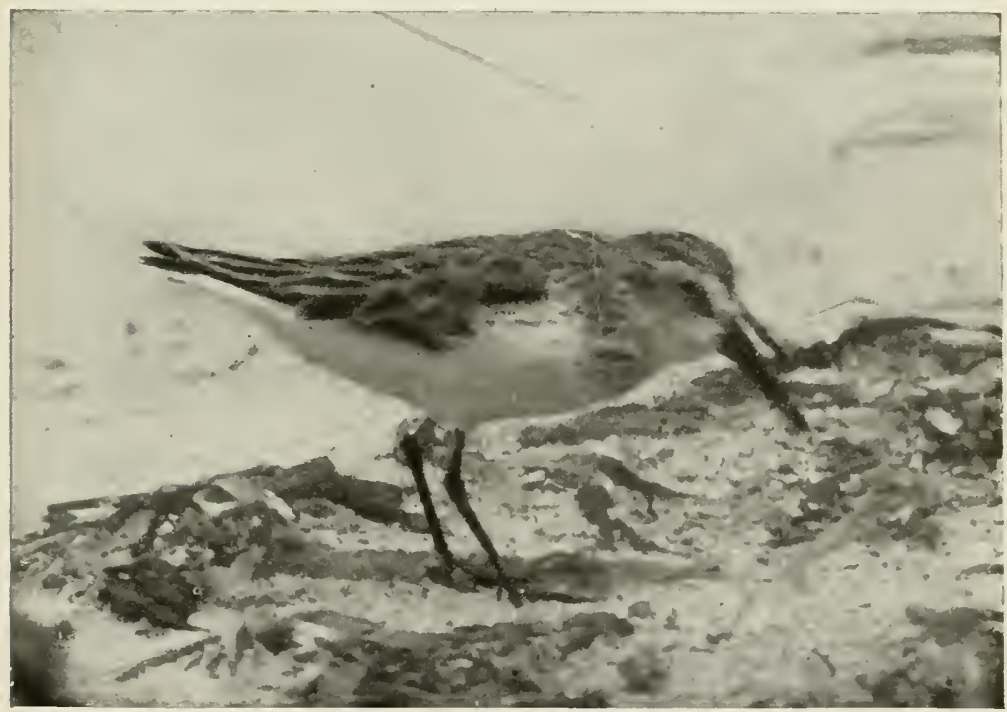

Semialmated Sandpiper feeding. "Along the shores of . . . lakes" (p. 253). 


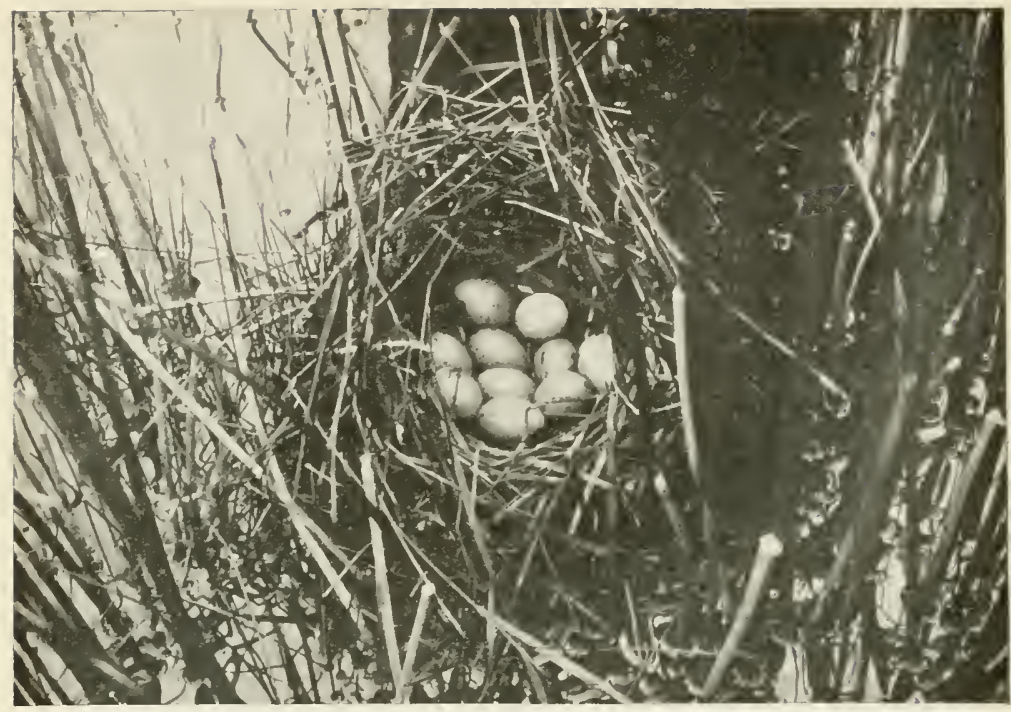

Nest of Sora. "They build a little hollowed platform" (p. 957).

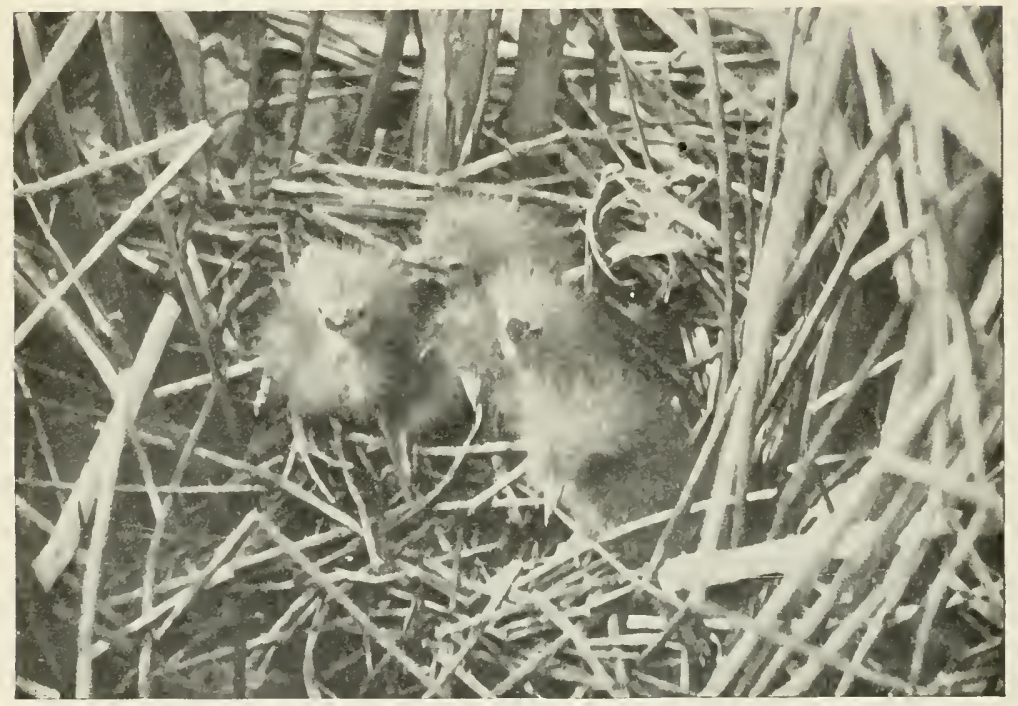

Young American Bitterns. "A rude nest of stems" (p. 261). 


\section{WATER-BIRD WAIFS}

well back from any water at all. I have found nests in such places as fields of potatoes or corn.

There is another species closely related to the last which should not be confused with it-the Solitary Sandpiper. In May, or in August or September, we are liable now and then to meet one feeding along the muddy or spongy edge of some little pond hole, or in almost any sort of a wet place. Sometimes there will be a pair of them, but more often the bird is alone, solitary in reality, as in name. It nests in the far north, and until very recently its breeding habits were unknown, till its eggs began to be discovered, in the Canadian Northwest, in abandoned Robins' nests up in trees. It is not known to breed in the United States. One can tell it from the Spotted Sandpiper by its much darker back, and from the Yellow-legs by its greenish legs. It is a beautiful, gentle bird, and I love to sit and watch one feed in a bog, so graceful, so neat in person, with the bearing of real refinement-sandpiper good breeding.

Next comes the order of marsh-dwellers, the Paludicolce of science. Of these our principal group is the rails. These are birds which the average person never sees and has never heard of. But if one find the right place, some very oozy bog, overgrown with "cat-tails," and will throw a stone into it, so as to make a loud splash, like as not there will instantly arise a series of loud, wailing, craking cries. These are the rails, not fence rails, but real live ones, called thus, 


\section{WATER-BIRD WAIFS}

perhaps, because they are narrow across, "thin as a rail," so that they can the more easily slip through the dense tangles in which they live. One may suppose that the fat ones got stuck, but the thin survived, and gave rise to a thin race!

With us there are two common kinds of rails-the Virginia Rail and the Sora, the latter being the best known, especially to sportsmen, for rails are hunted with dogs, and their flesh is good eating, as those things go. But in these days of decreasing bird-life, the true bird-lover is more inclined to look to the butcher for meat and to the wild birds for pleasure of eye and ear rather than of palate. To esteem a bird in accordance with its edibility is getting to seem a little uncouth and old-fashioned. A while ago I was showing to a gentleman of foreign extraction some of my best bird pictures, enlarged and hand-colored, which I really thought were pretty nice. As I showed him each picture, his one and repeated question was, "Is it good to eat?" If I said "yes," he looked rather pleased; if I said "no," he gave a sort of impatient grunt of disgust-no good! I soon began to have "tired feelings," and was not sorry to depart.

These rails are rather small birds, about the size of the Bobolink, short of tail but long of toe, and well developed in the legs. The Sora is dark colored, with short bill, while the Virginia Rail, though but a trifle larger, can be told by its reddish-brown color and longer bill. Neither of them likes to fly, and they only 


\section{WATER-BIRD WAIFS}

do so when migrating, or when compelled by the close approach of some intruder. Then they will flutter feebly up and drop into the grass before going many rods. They have their run-ways through the tangle of grass and weed, and run and climb with the greatest of nimbleness. They are especially active at twilight, and perhaps at night. In the dusk of the evening I have seen them appear again and again at the edge of some marsh, or scurry across open spaces from one clump of reeds to another, and I have seen them run on lily pads. I have found their nests, not so much in the thickest tangles as near the border of a meadow or bog, in the rather sparse meadow grass, where the water is only a few inches deep. They build up a little hollowed platform of dead grass among the green stems, slightly above the water, and draw and tie the ends of the grass over it, to form a nice little canopy. All rails lay a large number of eggs, six to thirteen ordinarily, and once I found sixteen in a Sora's nest.

The young of all rails with which I am acquainted are covered with a black down, and, almost from birth, are great runners. Once I tried to catch a young rail. It ran out into a place where there were few stems of grass, almost an open mud-flat. I sprinted along, plastering myself with mud, but sure of my prize, which I only wanted to photograph before releasing. Just as I thought I could seize it, suddenly it stopped, out there in the open, with next to nothing to conceal 


\section{WATER-BIRD WAIFS}

it. But for the life of me I could not see where it had gone, and I finally had to give it up.

When I was of high school age I took a companion of about my years into a famous rail-bog, where many pairs nested, as he wanted to find some of their eggs. The place was a sort of bottomless ooze, and we had to lay out planks and step on them. Though I had cautioned him, he soon slipped off and got into the mud. We were rather near shore, and he was so frightened that instead of climbing back on the plank, he started to wade ashore, despite my protests. Deeper and deeper he sank, till he was in all over. Now he was frantic with terror and began to cry. I thought surely he would drown, but he finally crawled out on shore, plastered with black oozy slime from head to foot. Choking with mud and sobs, in about equal proportions, he started for home spluttering that I'd never have the chance to get him into such a scrape again-how ungrateful! This was just on the border of the city of Boston, and I badly wanted to hear all about his trip through the city streets in that rig. But he hardly would speak to me after that, much less go into detail. This incident goes to show that if anyone is afraid of mud and water, he or she had better let the rails alone and study the safe and darling little chippybirds!

There are some other rails that must receive only scant mention. The Little Black Rail and the Yellow Rail are both very rare, and have almost more the 


\section{WATER-BIRD WAIFS}

habits of meadow mice than birds, as they run through the grass, and it is next to impossible to make them fly. Sometimes they are caught alive by the hunting dogs. Then there is the large species called King Rail, found in Middle and Southern States, seldom plentifully, and the Clapper Rail, or Marsh Hen, of the salt marshes along the coast from Connecticut southward. The Florida Gallinule is much like a large rail, and is found sparingly in fresh-water bogs, being common only in the South, where I have found their nests, similar to the rails', among the rushes in bogs. The American Coot, sometimes called "Blue Peter," or Mud Hen, is rather common, in the same sort of haunts, in migration. Having lobed feet and compact plumage, it swims, as does the webless gallinule, and is often mistaken for a duck. It is a gray bird about the size of a pullet, with bill like the latter and a patch of white above its base. They bob their heads back and forth as they swim. Out in the Northwest I have found hundreds of their nests in the great sloughs in the reeds, basket-like affairs of reed stems, with from six to a dozen finely speckled eggs.

Next we have the heron tribe, and interesting birds they are. The Great Blue Heron is the biggest of them, so tall that it gets the popular name of Blue Crane, which is inaccurate, for it is no crane at all. They are not plenty, and nest now mostly in the North, but also in wild Southern swamps, in both of which regions I have found their nests, generally in colonies, 


\section{WATER-BIRD WAIFS}

and up giant trees. But we may now and then run across a solitary Great Blue by the edge of some body of water or feeding in a morass. They are among the wariest of birds, and will not allow a person to come anywhere near them-not if they know it.

Another well-known Northern heron, famous for its great nesting-colonies, is the Black-crowned Night Heron, familiarly called Quawk. On the seacoast they are more common than in the interior, in which latter region they are very locally distributed. In the locality where I now live they are seldom seen, except in migration, when I sometimes hear the harsh "quak, quak," as one flies orer in the evening, high in air. I have often been into their rookeries in lonely swamps where from a dozen to thousands of pairs had built their rude nests, sometimes half a dozen or more in one tree. Everything there is nasty and ill-smelling. One of my earliest recollections of herons is of climbing to one of these nests, in a small colony in a cedar swamp, and having the young, according to their habit, vomit out partly digested fish from their crops into my face as I climbed. This bird is of good size, the adults quite light in color, but the immature birds are of a dull mottled brown.

The American Bittern, Stake-driver, or Post-driver, as it is variously called, is of about the same size, and somewhat resembles the young of the preceding, only the brown is of a darker, richer shade, and the adult 


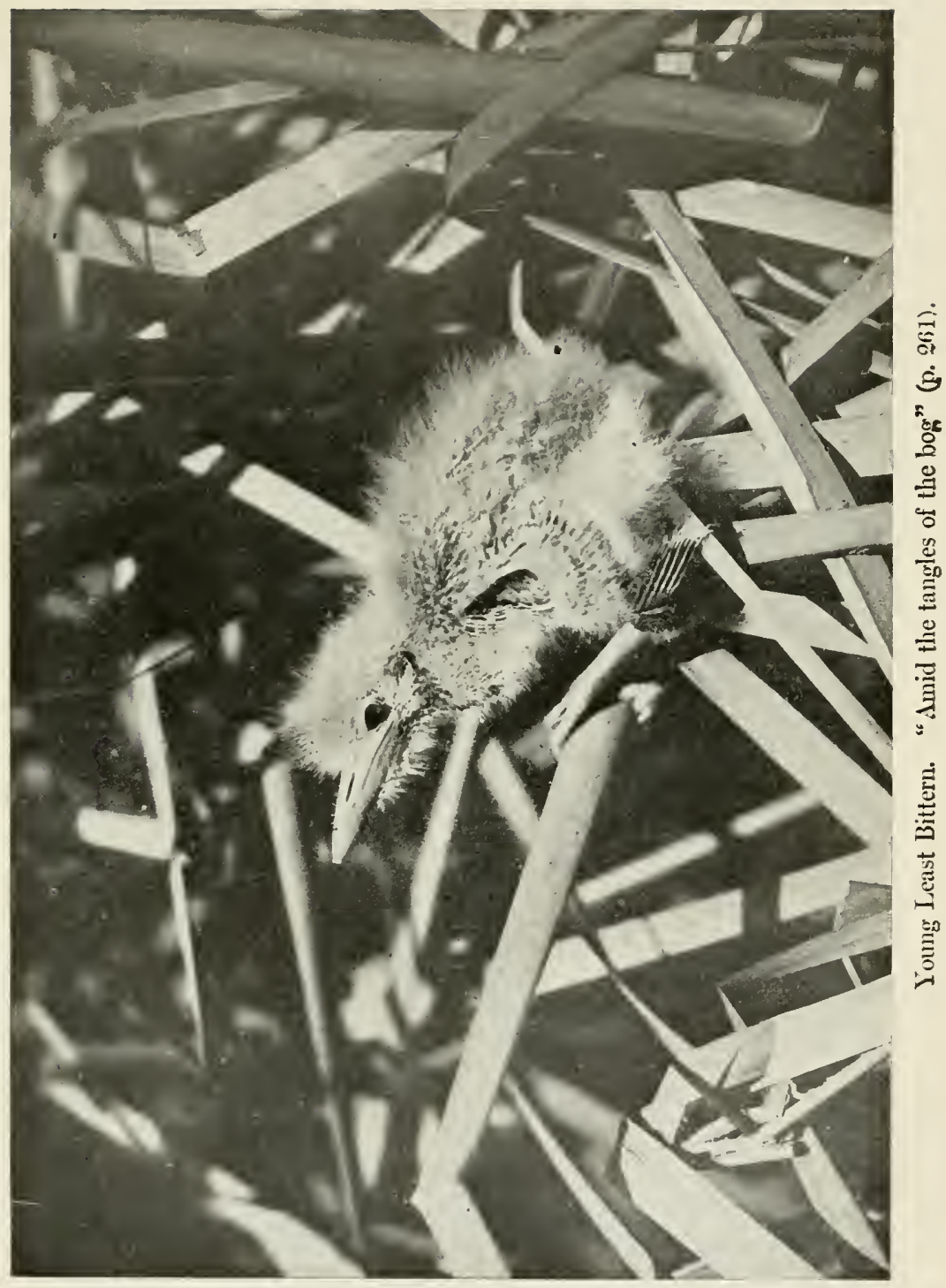




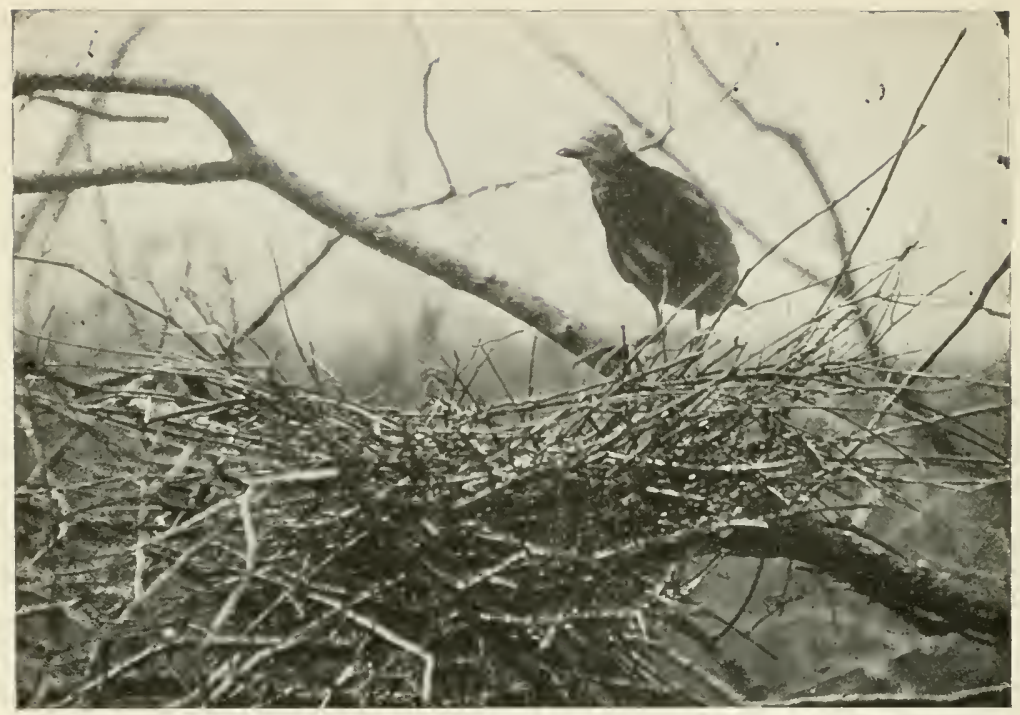

Green Heron and nest. "Came sneaking back" (1. 262).

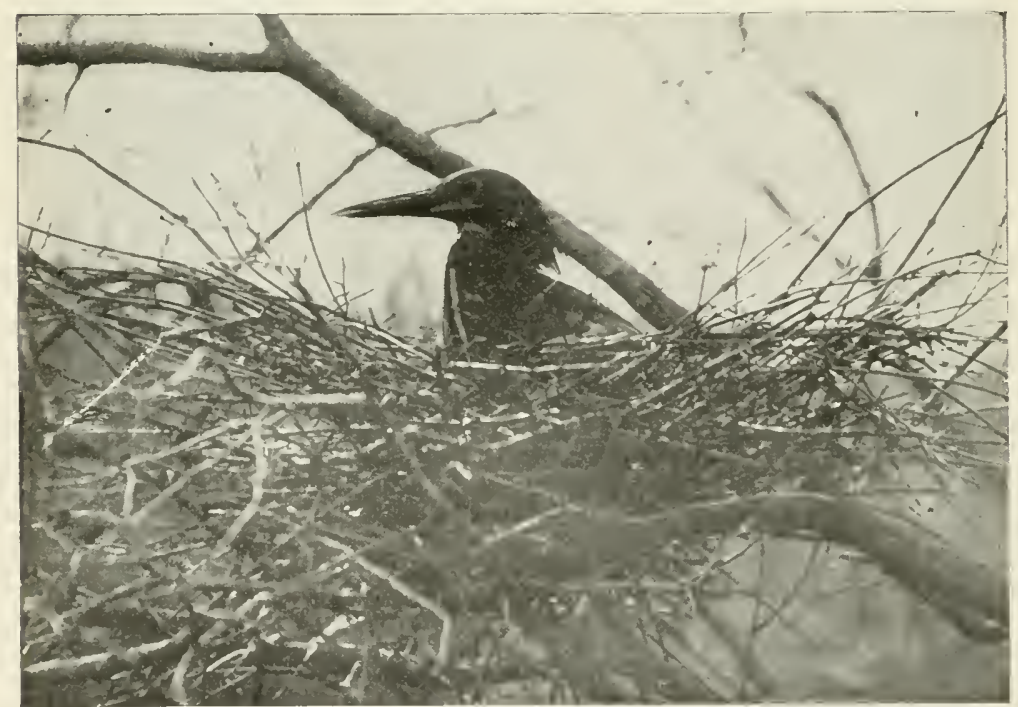

Gree: Heron incubating. "Plucked up courage to return" (p. 2262). 


\section{WATER-BIRD WAIFS}

has a prominent black stripe down each side of the neck. This is the bird which makes the booming or pumping noise out in the meadow or bog. In such places it lives, never in woods, nor in colonies, unless one can call a few pairs scattered over a big swamp such. They nest with us, and each pair makes a rude nest of stems on the wet ground in the bog, generally among reeds or rushes, sometimes grass, and lays from four to six large deep olive brown eggs, very different from the pale blue eggs of the other herons.

Like it in some respects in haunts and habits is its relative, the Least Bittern, a tiny fellow that is much like a rail in size and appearance, though its long neck serves to distinguish it. It is yellowish in color, with dark greenish back and crown. Its life is spent slipping about amid the tangles of the bog, where it builds its frail platform of a nest suspended between the reed stems in a clump, usually three or four feet up. The four or five eggs are bluish-white.

Probably the best known and most generally distributed of our herons is the common Green Heron, or Poke, a rather small, dark-colored species. Any wood-bordered pond or wooded or bushy swamp is liable to have from one to several pairs inhabiting it. They live on small fish, frogs, lizards, and the like, and nest in solitary fashion, either in some low evergreen in the woods just up from the pond, or in a bush out in the swamp. When one approaches the nest, 


\section{WATER-BIRD WAIFS}

the old bird will fly away and then return and perch a little way off and say all sorts of unutterable things in the uncouth heron-language.

In a certain swamp near my home several pairs of Green Heron usually nest. The place is a tract of alder bushes overflowed from the pond. The water is from knee to waist-deep, and the bushes grow out of the water. Once I undertook to photograph a Green Heron on a nest which was favorably situated, very low down. I set up the tripod near by, under the next bush, tied the focus-cloth about the top to suggest a camera, decked it with leaves, and left it over night, for the heron to become accustomed to it. Next morning I found her on the nest all right, so I substituted my camera for the cloth, covered and arranged it with thread attachment, and then hid about thirty yards away between three tree sprouts which grew from a stump, a nice little island nook. After about half an hour's wait, the heron came sneaking back, climbing almost parrot-like from bush to bush. All the time she was jerking her little tail in such a nervous, comical fashion that I felt like laughing right out, which, of course, would not do if I was to get a photograph. After some hesitation she stepped into the nest and settled down, but the instant I drew in my slack of thread she saw it move, and departed in as great terror as though I had fired a cannon. After awhile she plucked up courage to return, and this time I saw to it that the shutter would spring the instant I 262 


\section{WATER-BIRD WAIFS}

pulled. I finally "got" her, three times on the nest and once just stepping upon it.

These are the five common herons that are ordinarily seen in the Eastern and Middle States. A number of other species are well known in the South, and nearly all of them have appeared accidentally as far north as New England, particularly the Little Blue Heron, the American Egret (celebrated for its aigrette plumes), and more rarely the Yellow-crowned Night Heron.

Ve come now to the swimming-birds, and find the Anatide, or ducks and geese, in order. Almost everyone is interested in wild ducks. If a flock are known to alight in a pond, it is the talk of the neighborhood, and, unfortunately, every person owning a gun is crazy to get a shot. Consequently they are scarce in our Eastern districts, and with the growth of population are becoming more and more so. It seems so strange and delightful out in the Northwest to see companies of wild ducks swimming about in small ponds or pools right by the homes of settlers, fearless and unmolested, raising their broods in the neighboring grassy sloughs, practically in the barnyard pasture. How delightful if it could be so here! Once, indeed, recently, I came upon a brood of young Black Ducks, with their mother, within two minutes' walk of my house, on the edge of a meadow, but that was a rare treat.

This species just mentioned, properly the Dusky Duck, but popularly known as the Black Duck, is the best known and most common fresh-water duck of the 


\section{WATER-BIRD WAIFS}

eastern part of our country. They are shy birds and keep pretty well out of sight by day in the swamps. At dusk they begin to fly about and come into the ponds to swim and feed. I have stood silently on the edge of a morass, listened to their subdued quackings as they fed, heard the whistle of their wings, and seen their shadowy forms as they passed overhead. I have found their nests, too, now and then, but always by accident. The nest is always on the ground, hidden among the rank vegetation, or by the edge of a body of water among the rushes or under a bush. Not long ago I was shown one under an isolated thorn bush right out in an open field, not far back from the bank of a river. A trout fisherman happened along and flushed the bird from her eggs. These are usually from eight to twelve in number, as is true of nearly all ducks, and they are laid usually by the middle of April, sometimes earlier. The nests of all ducks are lined softly with down which the mother plucks from her breast. These ducks remain with us in winter as long as they can find water. I have seen them swimming in brooks in the swamps when the ponds were frozen over.

There is one other species which breeds in all our Eastern States, the beautiful Wood or Summer Duck. The drake is one of the most gorgeously beautiful of all our native birds. It is deplorable that they are decreasing so rapidly as to be on the brink of extermination. Some states are entirely prohibiting their being $26+$ 


\section{WATER-BIRD WAIFS}

shot for terms of years, and this should be done in all. A few pairs still remain in the locality where I live, and it is very interesting to run across them from time to time. They feed in the ponds and swamps, but when it comes to nesting, they are very different from the Black Duck, for they resort to hollow trees, and apparently are liable to go almost. anywhere. Their favorite choice seems to be an old hollow apple tree in an orchard. In certain orchards they nest year after year. Becoming familiar with man, particularly if not disturbed, they grow very bold and select the strangest sort of places for nesting-sites.

By all odds the most remarkable incident of this sort in my experience was when a pair selected a barn. The female would go through a broken clapboard into the hayloft. Scooping a hollow in the top of the haymow, she lined it with her down and laid ten eggs. While she was laying, the owner of the place would see the happy pair at daybreak perched on the ridgepole of the barn, making love. In another barn a nest was begun, but the birds were driven off. Another pair chose a hollow in a maple tree bordering the road, within a few rods of a house. The hole was only about five feet from the ground, and most of the neighbors knew of the nest, and would look in as they went by. Still another odd nesting-site came to my notice. Near where I live a farmer had a pig-pen just back of his house, and in it grew a hollow apple tree. On the eleventh of April this tree was cut down, and it was 265 


\section{WATER-BIRD WAIFS}

discovered that in the hollow trunk were eleven fresh eggs of the IVood Duck.

That same spring there was a legislative hearing regarding the abolition of spring shooting of wildfowl in the State, the existing law allowing shooting up to the first of May. Speaking for the proposed change, I showed by this instance and others the folly and enormity of a law which allowed these valuable and fast disappearing birds to be shot when they actually had eggs. I am glad to say that the obnoxious law was repealed, and all shooting forbidden after the first of January, which is as it should be. The wildfowl mate very early in the spring, or even in winter. In the spring the mated birds are tame and easily shot. Moreover, they are usually in poor flesh at this time and almost worthless as food. At any rate, it is a case of killing the goose that lays the golden egg, and every bird-lover ought to use all influence against such atrocities as spring shooting, and in every way take a public-spirited stand for the preservation of all our beautiful harmless wild life, the existence of which adds so great charm to the outdoor world. As I heard it well put by a teacher at the legislative hearing, "Why have not we, who are as fond of birds as you hunters, just as much right to demand that we shall have birds to see and study as you to demand that you shall have them to shoot?"

There are various other ducks which drop into our ponds and rivers from time to time, especially in 266 


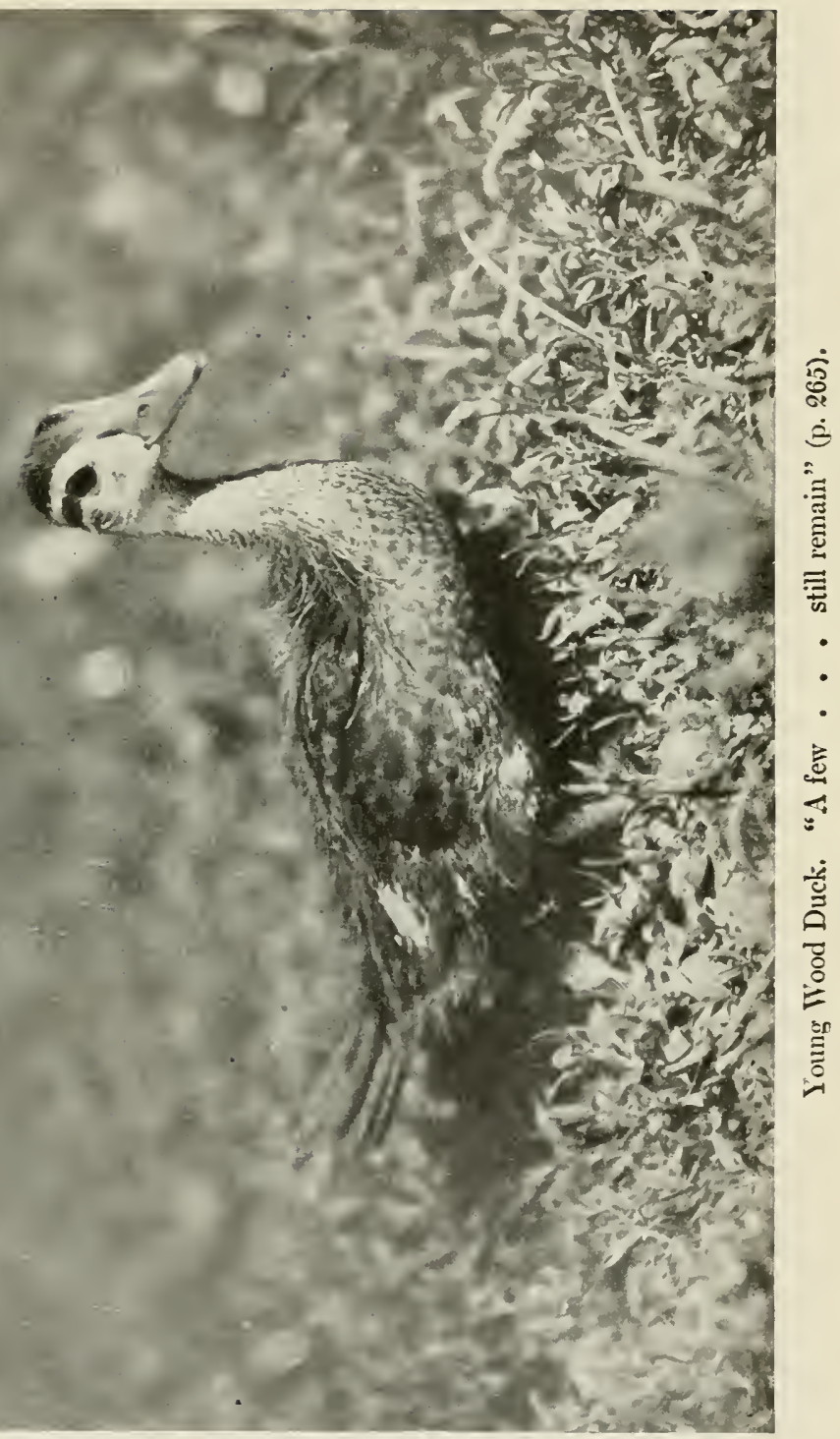




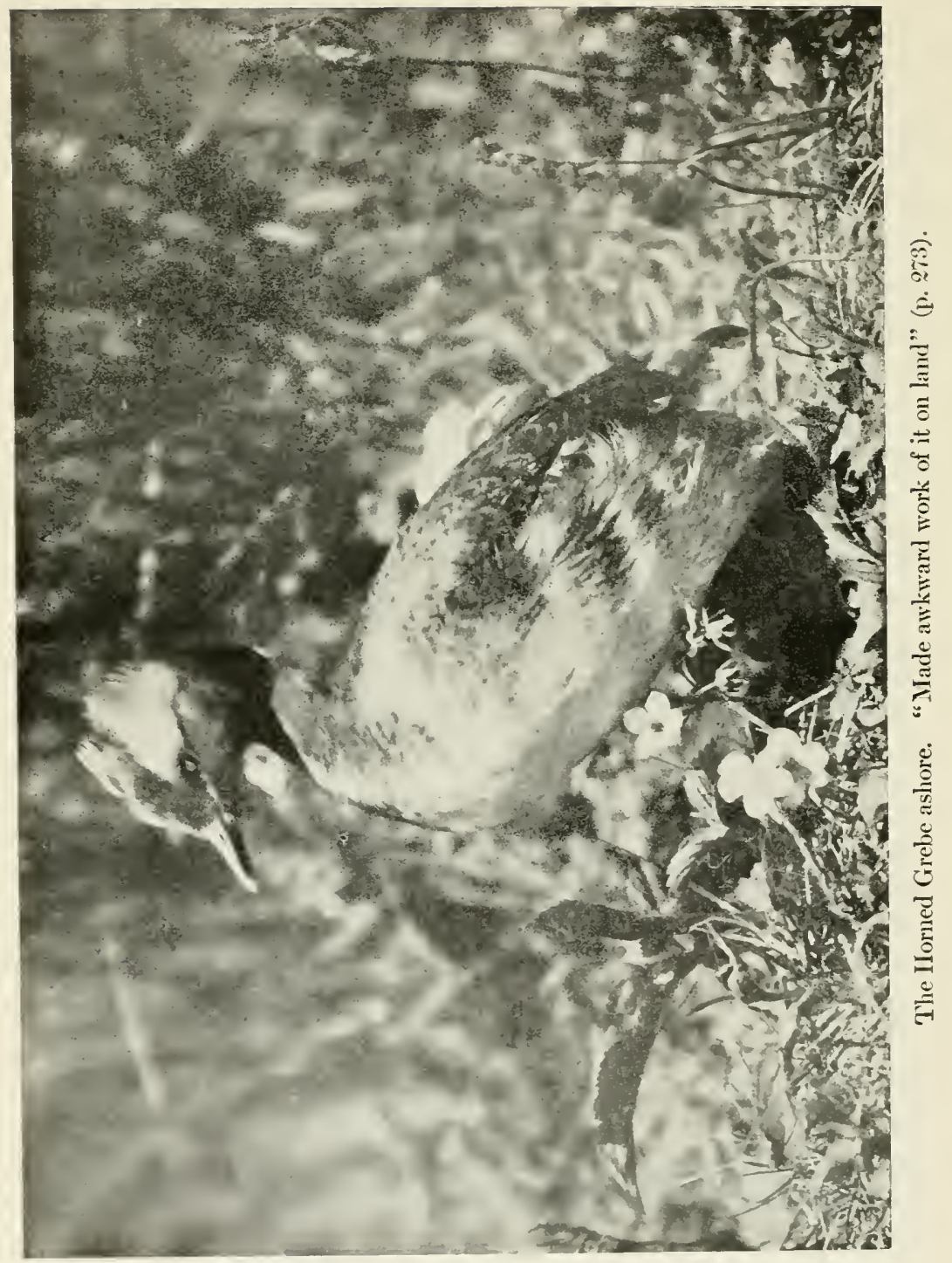




\section{WATER-BIRD WAIFS}

migration, which must at least be mentioned, though their numbers are but small. Some of these casual migrant visitors are, for instance, the fine large Mallard, which is more of a Western species; the Pintail, Baldpate, and Gadwall, which are grayish, rather nondescript in the fall plumage, when we generally see them, and hard to tell apart; the Red-head, somewhat similar to the larger, whiter and rarer Canvasback, which latter is now very rare with us; the curious little Ruddy Duck, a tame brownish bird, with a stiff tail, now and then appearing in flocks, which are soon shot off; those miniature ducks, the Blue-winged and Green-winged Teals, delightful, sprightly little people, all too scarce. The Greater and Lesser Scaups, or Blue-bills, sometimes flock in to the larger ponds or lakes late in the fall, when we may also see the American Golden-eye, or Whistler, which makes a pleasing æolian-harp humming sound with its wings as it flies. Its small near relative, the Bufflehead, I used to see, but less often of late years. A heary easterly gale in October and November will often drive in certain sea ducks from the ocean to ponds far inland. Such are the three large black or dusky species called Scotersthe Surf, White-winged and American Scoter-and the black and white, noisy "Old Squaw," or Long-tailed Duck. I remember one storm, in the middle of one October, which drove hundreds of these sea ducks into ponds a hundred miles from the coast.

Besides the above there are also three species classed 267 


\section{WATER-BIRD WAIFS}

as Fish Ducks, or Shelldrakes, species with long serrated bills, well adapted to seizing fish. They are the Redbreasted Merganser, the Goosander, and the Hooded Merganser, that being the order of their abundance. The first two are quite often seen from November to April in rivers or ponds, and, when these partly freeze up, in air holes, or even on the ice. In winter they are grayish birds above, and white beneath, with white on the wings. The head is crested, brown usually, but the heads of the males change to a dark green in early spring.

All these marine or Fish Ducks are poor eating, despite the best of cooking and parboiling, but with ordinary culinary methods they are impossible. On a southern yachting cruise one of our party shot two Red-breasted Shelldrakes, which the darky steward served up for dimner, as he would have done Mallards or Canvasbacks. Each man got the first mouthful at about the same time, and there was a simultaneous scramble for the hatchway to dispose thereof. The remainder was promptly fed to the fishes, and we indulged no more in roast shelldrake!

There is but one species of wild goose which we can expect to visit us inland, the Canada Goose, which we ordinarily see in wedge-shaped flocks in carly spring or late fall, gliding along with measured wing-beats, and honking forth those wild calls that send thrills through everyone who is capable of being stirred by the sights and sounds of the wilds. Sometimes they 268 


\section{WATER-BIRD WAIFS}

descend into the ponds, and there is a scurrying among the gunners. I have found their nests out in the wilder parts of the Northwest, and there studicd them as there is little chance to do here in civilization.

People usually think of the graceful and beautiful gulls and terns as being found only by the sea. In the East this is mainly true, but in the Northwest many of the marshy or alkaline lakes fairly teem with a number of kinds. But with us in the inland country town all we can hope for is to see a straggler now and then, if we have any ponds or lakes of fair size. In the early fall we may occasionally see a tern, probably the Common Tern, a white bird, about the size of a pigeon, gray on the back, and black-capped, whose long narrow wings move rapidly as it darts about, plunging headlong into the water after the small bait fish upon which it lives. Now and then the Black Tern, a smaller, slaty-colored bird of similar form and habits, may appear. Later in the season, about November, an occasional gull may winnow about the lakes. Probably it will be a Herring Gull, or perhaps the Ring-billed Gull, a trifle smaller. These are both much larger than terns, of heavier build and slower in motions. Adults are mainly white, while the younger birds are brown in their first autumn and gray in their second. A good time for the dweller inland to watch the gulls is when visiting some seaport city like New York, from November to April. Go down to the wharves or out in a ferry boat, and one will see more gulls in an 


\section{WATER-BIRD WAIFS}

hour than in the home town in ten lifetimes. However, I have seen them flying over the hill towns in midwinter, high up in the air, probably migrating to some distant body of water.

Perhaps the most satisfactory of our water-birds to actually see and watch are the peculiar tribe of divingbirds considered as the lowest of our forms of birdlife, the loons and grebes. Of these we may hope to meet in our ponds one species of the former and three of the latter. The common Loon, or Great Northern Diver, is the splendid big fellow, as large as a goose, which we note some morning floating on the placid lake. Now and then it dives below the surface, and after a minute or so, which seems a long time to hold one's breath, comes up quite a distance away. They breed from northern New England northward, and we see them on their migrations, mostly in the fall. They are not apt to rise on wing and leave the pond by day, but under cover of night, as their wings are small for the size and weight of their bodies, and they do not attempt to fly oftener than necessary. Their cries sound like a sort of wild laughter, "ha-ha-ha-ha-ha," and so the saying has come into use, "crazy as a loon." One hears these sounds mostly at night or in threatening weather, and they certainly sound weird enough.

Of the grebes which come into fresh Eastern waters, the largest and scarcest is the Holboell's, or Red-necked Grebe, which is nearly as large as a duck. The other two are smaller, about the size of teal-the Horned $2 \% 0$ 


\section{WATER-BIRD WAIFS}

Grebe, and the Pied-billed Grebe or Dabchick. The Horned Grebe is so called because in the spring plumage it has, particularly the male, a sort of muff of long feathers on its head, some of which stick up like little horns. They are otherwise strikingly colored with varied rich browns and black, but in autumn they are reduced to plain gray back and white breast. The Dabchick, which is by far the commoner of the three, zan be distinguished by its browner upper breast, and, in spring, its plainer garb. Most of the grebes seen will prove to be this latter. The time to expect them is during May and in September and October. They look so pretty, floating on the surface of the pond, often among lily pads, dabbling in the water with the bill. Usually we see each bird alone, but they are apt to migrate in small flocks, and th other members of the party are probably scattered shout the pond, perhaps hiding in the reeds along the margin, or crawled out upon the shore to sun themselves and preen their feathers. They do this ast also when afloat, and we can see them turn over on one side to get at the lowrer feathers, and the siky white under-parts will flash in the sun. It is even harder for them than for the loon to fly, for their wings are very small, and they likewise migrate by night. They are great divers, and if alarmed will plunge or sink into the depths, come up a long way off, stick out only the bill for a breath of air, sink again, and get out of sight without showing themselves even once. Knowing their powers they are not 


\section{WATER-BIRD WAIFS}

very shy, and will not fly away as would wild ducks when we approach. So we may quietly watch the grebe from the shore, and, especially if one has a strong field glass, it is a beautiful sight. The popular name of "Water Witch" is . tribute to the tribe's aquatic skill.

Though out in the Wes: I have seen thousands of these grebes, and others, in their breeding colonies, I never had a better chance to observe one intimately than one May right at home. A pair of Horned Grebes alighted in a brook, but could not fly out, because, with their small wings, they require a lot of room to flutter and patter over the water in geiting started. One of them disappeared, but the other stayed in the part of the brook near a house with a flock of tame ducks. A netting had been placed at the upper end to keep the ducks from swimming upstream, and below there was a bridge, under which the bird apparently did not like to go. The brook was hardly two feet wide, and Ned and I went there for several days and watched and photographed His Majesty. When we approached, the pretty fellow, a male in fine plumage, would dive and paddle off under water like a streak, and it was so shallow that he was in plain sight, and we saw that he used only his feet, not the wings, as propellers. Sometimes he would flutter along the surface of water, and then dive. After a time he became used to us, so I would sit quietly on the bank with the reflecting camera, while Ned would make him swim back and 2า2 


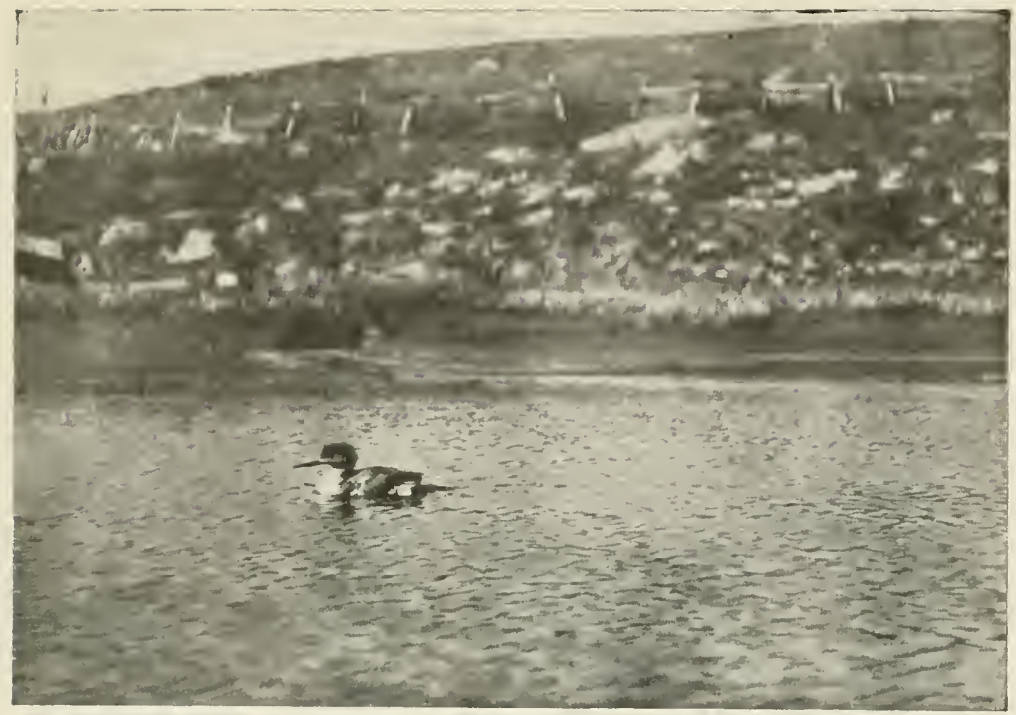

Red-breasted Merganser. "Quite often seen in rivers and ponds" (p. 268).

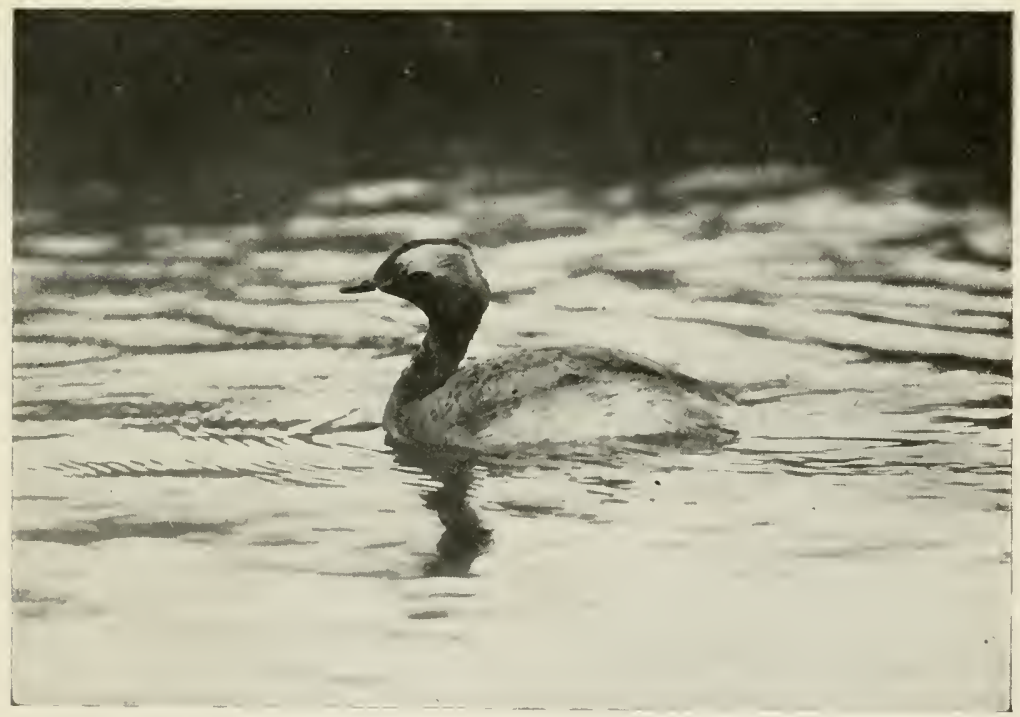

The Horned Grebe in the brook. "Giving me splendid camera shots" (p. 272). 



\section{WATER-BIRD WAIFS}

forth past me, giving me splendid camera shots. The! he would float quietly, a little apart from the ducks, preen his feathers, flap his wings, or dive and chase small fish. We could see him darting after them with. great eagerness, now this way, now that.

Finally we stretched a mesh of chicken wire for a net across the brook. Ned chased the grebe into the wire, and I seized him as he was strugghing to get through. When I took him out of water he would wave his muscular paddles so fast that they fairly blurred to our sight. 'These join the body down by the tail, so that the grebe must walk almost upright. He made awkward work of it on land, falling flat when he tried to run. After photographing him, we boxed him up and expressed him to the Bronx Zoölogical Park, in New York City, where I think he lived very happily with a mate they happened to have for him.

This brings me to the end of the pleasant task of telling in a familiar way of the pleasure which I, by myself, or in the lively, cheerful company of a boy, or of others, have found in following up the birds of a typical country region and becoming better and better acquainted with them. I hope that Ned may find bird-study a life-long delight and means of health and vigor, as I have done, and with him a host of othersboys and girls, men and women.

This is not saying that there are not a great many other interesting things in life. Indeed, as for myself, I am not a mere bird-specialist, but am interested in 273 


\section{WATER-BIRD WAIFS}

various other lines, aside from bird-study and my regular profession, such, for instance, as music. I do think, however, that it is a great advantage for everyone to have some sort of avocation, certainly at least one outdoor hobby, for the sake of health, and in any case a deep and abiding love of the beauties and glories of Nature, which makes for the strengthening of power of observation, the broadening and deepening of the life, and the cultivation of a spirit of calmness, optimism and buoyancy, which, if gained, will keep one in spirit ever young.

All too long, notably during the greater part of the nineteenth century, there has run riot a craze for the slaughter, for one purpose or other, of all the wild bird and animal life of this country. Some valuable and interesting species have been exterminated, and others are all but gone. Surely it is high time to call a halt! Fortunately, during recent years, and notably in the last two decades, there has set in a mighty tide of interest in these wild creatures-of sympathetic study of their habits, of kindness to them and of laws for their protection. The more universal this humane sentiment becomes, the better for our beautiful and harmless wild life, and the enjoyment of it by increasing multitudes. Many factors aid in the spread of this movement, minimizing the desire to kill and multiplying enjoyment of wild bird and animal life unharmed and at peace in natural surroundings, not the least of which is already proving to be "the sport of bird study." 


\section{THE BIRD-HOUSE OF SCIENCE AND \\ A BIRD CALENDAR}





\title{
THE BIRD-HOUSE OF SCIENCE
}

\author{
OF NORTHEASTERN NORTH AMERICA
}

SIMIPLIFIED FOR THE BEGINNER, WITH ONLY POPULAR ENGLISH NAIES

\section{A.-SIVIMMIING BIRDS}

I. ORDER OF DIVING BIRDS.

1. Grebe Family.

2. Loon Family.

3. Auk, Murre and Puffin Family.

II. ORDER OF LONG-WINGED SWIMMERS.

1. Jaeger Family.

2. Gull and Tern Family.

III. ORDER OF TLBE-NOSED SWIMMIERS.

1. Petrel and Shearwater Family.

IV. ORDER OF FOUR-TOES-ITEBBED SWIMIMERS.

1. Gannet Family.

2. Cormorant Family.

V. ORDER OF GOOSE-LIKE SWIMIIERS, OR WILDFOWL.

1. Duck, Goose and Swan Family.

$$
\text { B.-WADING BIRDS }
$$

I. ORDER OF HERON-LIKE WADERS.

1. Heron, Egret and Bittern Family.

II. ORDER OF MIARSH-DWELLING WADERS.

1. Rail, Gallinule and Coot Family. 


\section{THE BIRD-HOUSE OF SCIENCE}

III. ORDER OF SHORE-DWELLING WADERS, OR SHOREBIRDS.

1. Phalarope Family.

2. Snipe and Sandpiper Family.

3. Plover Family.

4. Oystercatcher Family.

\section{C.-LAND BIRDS}

I. ORDER OF GALLINACEOUS OR HEN-LIKE BIRDS.

1. Grouse and Quail Family.

2. Pheasant Family. (Introduced.)

II. ORDER OF PIGEON-LIKE BIRDS.

1. Pigeon and Dore Family.

III. ORDER OF BIRDS OF PREY.

1. Vulture Family.

2. Hawk Family. (Hawks, Falcons and Eagles.)

3. Owl Family.

IV. ORDER OF CUCKOO-IIKE BIRDS.

1. Cuckoo Family.

2. Kingfisher Fanily.

V. ORDER OF WOODPECKER-LIKE BIRDS.

1. Woodpecker Family.

VI. ORDER OF LONG-WINGED LAND BIRDS.

1. Nighthawk and Whippoorwill Family.

2. Swift Family.

3. Hummingbird Family.

VII. ORDER OF PERCHING BITRDS. (This includes nearly all our smaller Land Birds.)

1. Flycatcher Family.

2. Lark Family.

3. Crow and Jay Family.

4. Starling Family. (Introduced.)

5. Blackbird, Oriole, Meadowlark Family. 


\section{THE BIRD-HOUSE OF SCIENCE}

6. Finch and Sparrow Family, etc.

7. Tanager Family.

8. Swallow Family.

9. Waxwing Family.

10. Shrike Family.

11. Vireo Family.

12. Wood Warbler Family.

13. Pipit Family.

14. Thrasher and Wren Family.

15. Creeper Family.

16. Nuthatch and Chickadee Family.

17. Kinglet and Gnatcatcher Family.

18. Thrush and Bluebird Family. 


\section{A BIRD CALENDAR}

\section{WINTER}

Winter conditions begin with November and last till March. The winter visitors from the North may arrive from early November and on. Watcl for them among evergreens, in sheltered swamps, in pastures, or on open land where weeds have gone to seed. These birds can sometimes be approached and photographed with a long-focus reflecting camera.

In woods, or along their edge, Northern hawks or owls may be found, as well as those species which are resident. Flights of the Snowy Owl are most apt to occur, if at all, in early December, particularly along the coast.

Before the snow gets too deep, explore heavily timbered tracts to look up old nests of hawks and owls, which are likely to be occupied again. This will save time when the busier season comes. Look up new timber tracts. These woodland explorations in cold weather are fine, exhilarating excreise, especially if in hilly country. The wintry woods are interesting.

Put out food for birds around home. Hang up suct for woodpeckers, nuthatches and the Chickadee. Put trays of seed under some improvised shelter for Juncos, Tree Sparrows, etc. If there are quail in the vicinity, put out grain for them, sheltered so that the snow will not bury it. A large pile of hayseed is good, which can be readily dug out and turned over after each snowfall. By setting a camera focused on these baits, with thread attached to shutter, many a fine photograph may be secured.

From the latter part of January and through February locate by the hootings of the large owls the part of the woods which they frequent, for there they will probably nest. 


\section{A BIRD CALENDAR}

Regular daily exercise in the open air throughout the winter is the best prevention for colds and pulmonary diseases, and will keep one in fine, vigorous condition. In this way alone the sport of bird study would save thousands of lives, giving an interesting incentive to exercise outdoors.

\section{SPRING}

Spring is the harvest time for photographing birds, in which the nesting season gives by far the greatest opportunities, notably the last week of May and the first three of June. Incubation and rearing of young lasts from slightly over three weeks with the smaller birds to over two months with large ones like hawks or owls.

MARCH (first half). The first harbinger of spring, the Great Horned Owl, deposits its eggs from the last of February to the early days of March, seldom later, and is ready (:) to be photographed. Bluebirds, Song Sparrows, Robins and Red-winged Blackbirds arrive, early or late, according to the weather.

Marcir (last half). The Barred Owl lays from the middle of the month to early April. Early in this period expect the Fox Sparrow, Meadowlark, Rusty Blackbird, Cowbird and Woodcock, and somewhat later therein the Kingfisher, Grackle, Phobe, Mourning Dove, Wilson's Snipe, Swamp and Field Sparrows, with Cedar birds, wild ducks and Canada Geese in flocks. Be keen to get the first records of the season for the birds' arrivals, and the last ones of their departures.

April (early). Red-tailed Hawk and Woodcock lay, also Leng-eared, Screech and Saw-whet Owls, and some of the Redshouldered Hawks. A few more arrivals straggle in, such as the Ruby-crowned Kinglet and more of the hardier Golden-crown, which also winters, Vesper and Savanna Sparrows, Purple Finch, Myrtle and Yellow Palm Warblers, Great Blue Heron, American Pipit. Various ducks, the Loon, and the Holboell's Grebe are in transit, and may risit any inland waters.

ApriL (middle). Most of the Red-shouldered Hawks have laid by this time, also the Dusky Duck. Bluebirds, Crows and 281 


\section{A BIRD CALENDAR}

Robins also begin to lay. Notable arrivals are the Hermit Thrush, Sapsucker, and the first straggling swallows-Tree, Bank and Barn.

APRIL (late). Hairy Woodpecker, White-breasted Nuthateh and Song Sparrow lay, and quite a number of birds arrive-all the swallows, the herons, Whippoorwill, Chimney Swift, 'Towhee, Brown Thrasher, Chebec, and a few warblers, such as Blackthroated Green, Black and White, and Oven-bird.

MAY (first third). During this time the following hawks lay their eggs, usually finishing by the 10th: Fish, Cooper's, Marsh, Sparrow, and Broad-winged, the latter sometimes later. Night Heron colonies have eggrs early in the month. Blue Jay, Kingfisher, Vesper Sparrow, Grackles, Wood Duck and Ruffed Grouse lay-the latter sometimes earlier and later, and the IVood Duek sometimes earlier. In this period the great majority of our smaller birds not already mentioned begin to appear. The migration of all the warblers is in full progress by about the 10th. Horned and Pied-billed Grebes appear in the ponds or streams. Most of our small summer-resident birds arrive.

MAY (second third). 'The following lay their eggs: Swamp, Field, Chipping and Savanna Sparrows, Meadowlark, Phœbe, Barn Swallow, Green Heron, Louisiana Water Thrush, Sharpshinned Hawk. By this time all summer residents have arrived. The migration of shore-birds is at its height, especially, of course, in evidence along the coast, and likewise of the warblers and small land-birds in general. At this time there are more kinds and larger numbers of birds to be seen than at any other time of year. This is the time of times to detect rarities, and the birdlover might well wish to be afield every minute and to be multiplied a thousand-fold.

MAY (last third). Another contingent are now busy laying: Downy Woodpecker, Flicker, Chickadee, Purple Fineh, Brown Thrasher, Wood Thrush, Chewink, Veery, Spotted Sandpiper, Oven-bird, and early individuals of any of the warblers. The migrants are disappearing, the last being the Blackpoll Warbler in the early days of June.

June. By the first few days of the month nearly all the small 282 


\section{A BIRD CALENDAR}

birds have ordinarily completed their sets, unless the season be very backward, and many individuals in the last week of May. The great bulk of the small birds are now incubating, and by the 10th many eggs are hatching. The month from May 25th to June 25th offers more photographic opportunities bird-wise than all the rest of the year combined.

Some species which breed late are the following: Kingbird, Crested Flycatcher, Orchard Oriole, about the 10th; Vireos and Wrens are often somewhat late; Wood Pewee, 15th to 20th; Cedarbird and Chimney Swift from 20th to early July; the Goldfinch last of all, usually the last week in July or first in August.

\section{SUMMER}

Most of the species have finished or are finishing breeding by the time of the summer solstice. A few, just mentioned, habitually breed in summer. Some whose eggs have been destroyed lay a second litter, and others habitually rear two broods, in consequence of which facts occupied nests in sparing numbers may be found till late in the summer. The following species are among those which often raise two broods: Bob-white, Phœbe, Robin, Catbird, Bluebird, House Wren, Yellow-throat, most sparrows and swallows, Red-winged Blackbird, Meadowlark, and various others occasionally.

By July most of the birds become silent and secretive, having begun the molt. Some species, before migrating South, wander from their breeding localities, and species unfamiliar to a locality, like certain Southern herons, are noted as far north as New England or Nova Scotia. From mid-July and on, the flocking of certain species occurs preparatory to the migration, such as Swallows, Sparrows, Blackbirds, Bobolinks, Nighthawks. A few migrant warblers appear in August.

The return migration of the shore-birds begins about the middle of July, and is at its height in August. The latter month is a good time to visit the sea-coast to study shore-birds, Terns, ete., and for yachting trips offshore among the ocean birds, such 


\section{A BIRD CALENDAR}

as Shearwaters, Petrels, Jaegers, and Phalaropes. Good localities to find the latter class are the shoals off the southeastern end of Cape Cod, Massachusetts, or off Cape Sable, Nora Scotia. They can often be baited up with fish-livers close to the vessel and be successfully photographed.

\section{ACTUMN}

Before autumn has really arrived, many of the smaller birds have left for the South. The migratory species are now harder to find and to identify, being largely silent and in dull, nondescript plumage. Yet for all that it is interesting to be afield and to keep tally on the migration, recording dates of first and last appearance of all species observed. If done in friendly rivalry with others, this is very interesting, and it is a joy to exercise in the cool air amid the glories of autumn colors.

By the latter part of September, migratory ducks and grebes begin to appear on the various bodies of water, and during October the duck migration is at its height. Late October and early Norember bring many Northem sea-birds along the coast, some of which occasionally stray into inland lakes. A trip to the seacoast at this time among the hordes of mildfowl is a delight. The sea in an autumnal or wintry hurricane-what is grander!

Autumn is the shooting season for wild game. If you shoot, be content with a few game morsels for the table, and disdain to be so low-minded, in these days of growing scarcity of game, as to glory in a big bag. Learn to enjoy the pursuit more than the killing, the live wild creature in all its natural glory more than the dead trophy. Try for wildfowl and big game photographs, and as much as possible, let the camera usurp in your heart the altar formerly consecrated to the gun. 
A LIST OF THE BIRDS OBSERVED IN LITCHFIELD COUNTY, CONNECTICUT 



\section{A LIST OF THE}

\section{BIRDS OBSERVED IN LITCHFIELD COUNTY, CONNECTICUT}

Aside from any scientific or local interest, this list has a logical place at the end of this book. It is given as an illustration of one of the several possible applications of the fascinating sport of bird study worked out to a definite result. To undertake an exact faunal bird-census of any definite locality will lend interest and excitement to every tramp afield, and to every glimpse of an unusual bird, which, when identified, may add another name to the growing list. In the present case, as the roll swelled, my interest increased, and when I neared the two-hundred-mark the excitement was really delightful.

The following list is the result of my now nearly ten years' residence and field-work in the County, combined with some observations of a few others. The County seems to be almost a virgin field ornithologically, for no list and but few scattering notes from the region have ever before been published. The splendid field-work of Mr. E. Seymour Woodruff, in the town of Litchfield, especially as to the water-birds occurring in Bantam Lake, has been of immense value in preparing this list, and I wish to thank him for his coöperation, as well as Dr. L. B. Bishop, for examining my manuscript and giving me access to his vast store of material on Connecticut birds, which will be published later, and Messrs. Harrison Sanford, William Hanson, C. H. Pease, F. F. Stevens, J. S. Dutcher, E. H. Austin, 'T. S. Skilton and W. A. Miles, for interesting notes, as well as numerous other valued correspondents. 


\section{BIRDS OBSERVED IN LITCHFIELD COUNTY}

When this list was nearly ready for publication I discovered a man who has done more field-work in ornithology in this County than any other person, myself included-Mr. Charles H. Williams, of Winchester. For more than thirty years he has studied and collected, and the amount of his information, notes and specimens is astonishing. 'Though a man of culture, he has done this in obscurity and without publishing anything, purely from love of Nature. His written data and specimens abundantly prove his rare records. Unfortunately when I visited him his collections and notes were packed preparatory to moving, so that in many instances he could not give me exact dates of records, but he has them in most cases. This "List" and myself are both greatly his debtor.

It seems remarkable that so beautifully diversified a region should have been so neglected by students of birds. The whole County is an area of magnificent hills, deep valleys, rapid streams, everywhere picturesque. Bantam Lake and Twin Lakes are the principal bodies of water, but there are many smaller lakes and ponds. If my home had been accessible to the larger lakes I should certainly have added various other water-birds to this list. The region belongs to the Alleghanian faunal area, but the higher elevations with their hemlock, mountain laurel, occasional black spruce, and cold sphagnum bogs, afford a mingling of the Canadian fauna, and the deep valleys of the Carolinian. There is still a fine field for original investigation amid this glorious scenery, and a number of other species can surely be added to this list, the ferreting out of which offers fine incentive and splendid "sport" to those who are so fortunatc as to reside, pcrmanently or temporarily, in these delightful surroundings.

1. Holboell's Grebe. Colymbus holboellii. A rare migrant and winter visitor. I saw one which had been shot in a small pond in Kent, in April, 1904, and know of another taken in Litchfield. Early in February, 1908, one was found by Mr. George A. Clute alive in his yard on the outskirts of Sherman, close to the County line. 


\section{BIRDS OBSERVED IN LITCHFIELD COUNTY}

2. Horned Grebe. Colymbus auritus. Fairly common migrant, occurring more especially in the larger lakes. In May, 1906, I captured one in a brook, whence it was unable to fly out. Mr. Stevens finds them common in Twin Lakes in the fall,.sometimes abundant.

3. Pied-billed Grebe. Podilymbus podiceps. Common migrant, espeeially in autumn, in all ponds and rivers.

4. Loon. Gavia imber. A regular migrant, occasionally seen on the larger lakes. Mr. Williams finds them regularly in spring and fall in Winchester, and many years ago found a pair breeding there. Messrs. WVoodruff and Stevens report them, and Mr. Austin has seen one in Hatch Pond, Kent.

5. Brünnich's Murre. Uria lomvia. A rare straggler from the ocean in winter, blown in to the ponds or rivers during severe weather. In two cases in which I examined the specimen, both were of this species. Of these, one was taken at Still River, the middle of December, 1901, the other by Mr. C. S. Phelps, at Twin Lakes, in late December, 1907. Mr. Stevens has shot several in Twin Lakes, and has found one dead.

6. Bonaparte's Gull. Larus philadelphia. A rare migrant. One was shot by a gunner at Bantam Lake, July 1, 1892, and reported by $\mathrm{Mr}$. Woodruff, who also saw four small gulls at this lake on Sept. 24, 1895, which he attributes to this species. The Litchfield Scientific Society has a specimen shot in Litchfield in April, 1905.

7. American Herring Gull. Larus argentatus. An occasional migrant. Mr. Stevens saw two in 'Twin Lakes late in November, 1906, and has observed them there a few other times. On Feb. 5, 1900, I saw a flock of about a dozen, evidently of this species, high up over Kent, flying southward. Mr. Austin has several times seen them flying over.

8. Common Tern. Sterna hirundo. Terns undoubtedly of this species are occasionally reported from various ponds or lakes in late summer or early fall. Mr. Stevens has seen them several times on Twin Lakes.

9. Sooty Tern. Stema fuliginosa. Entirely accidental. One was 289 


\section{BIRDS OBSERVED IN LITCHFIELD COUNTY}

found dead in woods in Torrington about the first of October, 1891, by Mr. Ansel Wheeler, just after a severe storm. It is a tropical species, and this is the only County record, though it has been taken elsewhere in the State. I examined the specimen, mounted, at the home of Mr. Wheeler.

10. Black Tern. Hydrochelidon nigra surinamensis. A rare straggler from the coast. This is one of the terns which one would expect to find occasionally, but the only occurrence of which I know definitely is one seen by Mr. Williams in Winsted, on Old Park Pond, about nine years ago. It was in late September or early October, on a foggy day. There were other terns flying about, but only this one came near enough to identify.

11. Leach's Petrel. Oceanodroma lencorhoa. An accidental straggler from the ocean. One taken by Mr. James Truelove, flying about over Lake Wononscopomus, Lakeville, in October, 1904, after stormy weather, was reported to me by Doctor Bishop. Another specimen, recently seen mounted by Mr. Hanson, was picked up dead in Torrington in September, 1906.

12. American Merganser. Mergus americanus. A fairly common migrant and winter resident. From November to April I see small flocks in the Housatonic River, and they are reported elsewhere by a number of observers.

13. Red-breasted Merganser. Mergus serrator. More common than the preceding on the coast, but apparantly less so on the fresh waters of this County, where it is likewise a migrant and winter resident. It may occur quite frequently, but is hard to distinguish from the last. I saw one in Cornwall in early May, 1902, which had suddenly fallen from the air into the yard of Mr. T. S. Gold.

14. Hooded Merganser. Lophodytes cucullatus. An uncommon migrant. Mr. Woodruff reports one secured in Bantam Lake, Sept. 15, 1905. Mr. Williams sees them occasionally, and saw a female with young in Winchester about fifteen years ago.

15. Mallard. Anas boschas. An uncommon migrant. I saw 290 


\section{BIRDS OBSERVED IN LITCHFIELD COUNTY}

a beautiful drake which was caught in a trap in woods in New Milford in January, 1901. Mr. Williams sees them nearly every spring and fall, as does Mr. Austin.

16. Black Duck. Anas obscura. A common migrant and resident, breeding throughout the County.

17. Red-legged Black Duck. Anas obscura rubripes. This northern sub-species is quite common in the migrations.

18. Gadwall. Chaulelasmus streperus. This is one of the rarer ducks, but still occurs throughout New England. Most gunners confuse it with the Pintail and Baldpate, so it is hard to trace. Mr. W. A. Miles has shot specimens in Twin Lakes, and I heard of two being shot there the middle of November, 1907.

19. Baldpate. Mareca americana. Generally a scarce migrant, though not rare. Mr. Woodruff considers it "fairly common" about Bantam Lake. Mr. Miles has also taken it at Twin Lakes, and others report it there.

20. Green-winged Teal. Nettion carolinensis. A rather uncommon migrant. Messrs. Stevens and Pease have taken it frequently in Canaan, and Mr. Williams has seen an occasional one in Winchester.

21. Blue-winged Teal. Querquedula discors. Occurs only sparingly in the migrations, though years ago it was very common. Mr. Williams sees quite a number each fall.

22. Shoveller. Spatula clypeata. Formerly a common duck in the East, now rare. Mr. Miles has seen and shot specimens in Twin Lakes.

23. Pintail. Dafila acuta. A migrant, apparently not common, though it should occur regularly. Mr. Miles finds them at Twin Lakes, and Mr. Hanson saw a specimen which was shot on the river at Torrington, Oct. 25, 1907.

24. Wood or Summer Duck. Aix sponsa. Summer resident, everywhere becoming scarce, and said to be in danger of extermination. Some States are forbidding its capture at all, and all ought to do so, Connecticut, for instance. In Kent there are several pairs which still breed.

25. Redhead. Aythya americana. Not a common migrant. 


\section{BIRDS OBSERVED IN LITCHFIELD COUNTY}

Mr. Woodruff has found it numerous at times in autumn in Bantam Lake.

26. Canvasback. Aythya vallisneria. A rare migrant. Gunners think they have seen it, but the only record of its actual capture which I have is from Mr. W. A. Miles, who shot five from a flock in Twin Lakes late in November, 1896.

27. American or Greater Scaup Duck, or Blue-bill. Aythya marila nearctica. A common visitor to the larger lakes in migration, especially in late fall. Flocks of this species and the following are often found in Bantam Lake, as reported by Messrs. Woodruff and Sanford. This species appears to be the commoner of the two, as judged by the specimens shot, though the gunners are apt to pick out the larger birds.

28. Lesser Scaup Duck, or Lesser Blue-bill. Aythya affinis. Probably a rather common migrant, occurring in the larger lakes. Mr. Woodruff found them common in Bantam Lake, Oct. 14 to 19,1907 , and shot several specimens.

29. American Golden-eye. Clangula clangula americana. A migrant, not common. Messrs. Woodruff and Stevens have seen flocks in Bantam and Twin Lakes, and Mr. Austin has seen and shot them in the Housatonic River.

30. Bufflehead. Charitonetta albeola. A rare migrant. Mr. Sanford saw several on Bantam Lake Oct. 23, 1905, and later. Mr. Williams used to see them up to about fifteen years ago.

31. Old-squaw. Harelda hyemalis. A not uncommon migrant and winter visitor. Mr. Woodruff shot one and saw two more on Bantam Lake, Oct. 19, 1907. Another was shot later. Mr. Stevens finds them quite common at times in Twin Lakes, Mr. Williams has seen them in winter in the river near Winsted, and Mr. Austin twice in small ponds.

32. Harlequin Duck. Histrionicus histrionicus. A very rare migrant. Mr. Williams examined a male in full plumage shot by Matthew Parsons on Old Park Lake, Winsted, in October, seven or eight years ago. 
33. American Scoter, or "Butter-billed Coot." A maritime species, which occasionally appears in the larger lakes as a migrant. In $1905 \mathrm{Mr}$. Sanford found it quite common in Bantam Lake, occurring from October 20 on into November. Mr. T. S. Skilton, of Winsted, reports one flock from which he secured a number of specimens. Mr. Williams saw four shot in Winchester.

34. White-winged Scoter, or "White-winged Coot." Oidemia deglandi. Of the same status as the preceding, and similarly reported from Bantam Lake, at the same time. Mr. Stevens reports a large flock of sccters, one of which was shot and proved to be of this species.

35. Surf Scoter, or "Skunk-head Coot." Oidemia perspicillata. This species occurs along with the two last and is probably the commonest of the scoters, though confused by gunners with the American Scoter, in the immature plumages. On Oct. 10, 1900, out of a large number shot during a great flight in a severe storm, at Lake Buell, not far north of the County line, in Massachusetts, the great majority proved to be of this species, with a few "White-wings." Mr. Miles has shot them in Twin Lakes.

36. Ruddy Duck. Erismatura jamaicensis. A fairly common migrant. Mr. Williams finds it quite common both in spring and fall.

37. Canada Goose. Branta canadensis. A migrant, hardly common. Flocks are seen or heard in spring and fall on their migration. They sometimes alight in the lakes and rivers.

38. American Bittern. Botaurus lentiginosus. A frequent summer resident, though more common as a migrant.

39. Least Bittern. Ardetta exilis. A rare summer resident, but probably occurs oftener than is known. Mr. Williams saw a pair in Humphrey Meadow, Winchester, and found their empty nest, the latter part of May, about 1896.

40. Great Blue Heron. Ardea herodias. A fairly common migrant, rare as a summer resident. Mr. Williams found a 293 


\section{BIRDS OBSERVED IN LITCIFIELD COUNTY}

nest in Winchester about ten years ago. It is often seen singly in summer.

41. American Egret. Herodias egretta. An accidental wanderer in late summer from the South. I have a specimen taken in Kent by Mir. IV. T. Hall, July 28, 1899. Another was shot in Canaan July 25,1906 , and Mr. Pease has it mounted.

42. Green Heron. Butorides virescens. Common summer resident.

43. Black-crowned Night Heron. Nycticorax nycticorax naevius. Though a summer resident in colonies in various parts of the State, I have not learned of any breedingcolony in this County. It occurs, probably frequently, in migration or summer wandering. I have seen it flying over Kent, and it has been shot or reported by various observers.

44. Virginia Rail. Rallus virginianus. A not common summer resident and migrant. Mr. Williams found a nest with ten eggs in Winchester, and Mr. Woodruff has seen and taken it as a migrant in Litchfield.

45. Sora, or Carolina Rail. Porzana carolina. I have found it in Kent in the fall migration. Mr. Woodruff has detected it in the breeding season, and also in the fall. This species and the preceding are probably commoner than they seem; their mouse-like habits conceal them pretty effectually. Mr. Austin finds both frequently in migration.

46. Florida Gallinule. Gallinula galeata. A rare migrant, though probably it occurs oftencr than is supposed. Mr. Stevens shot one in Canaan, in September, 1907, and saw a specimen which was shot in September, 1906. Mr. Woodruff has one record, and Mr. Austin several.

47. American Coot, Mud-hen, Bluc Peter. Fulica americana. A migrant, not common. I have seen it sereral times on ponds in Kent in fall, as has Mr. Woodruff in Litchfield. Mr. Williams has seen but one individual in Winchester.

48. American Woodcock. Breeds generally, though sparingly: but is more common in migration. 


\section{BIRDS OBSERVED IN LITCHFIELD COUNTY}

49. Wilson's Snipe. Gallinago delicata. A migrant, not common. Mr. Stevens sees or shoots them now and then, usually finding a single bird, but he has seen as many as six at a time. One October I picked up one dead under a wire. Mr. Austin has frequently shot them.

50. Least Sandpiper. Actodromas minutilla. A migrant, not common, occurring chiefly along the shores of the larger lakes. Mr. Woodruff saw a number at Bantam Lake between May 18 and 23, 1905.

51. Semipalmated Sandpiper. Ereunetes pusillus. Probably occurs about as the preceding, but the two are confounded by most peoplc. Mr. Woodruff and his brother, L. B. Woodruff, identified one at close range on the beach of Bantam Lake, Aug. 21, 1893. Mr. Stevens described to me three which he saw on a marsh along the Housatonic River in late April, 1907, which I think were of this species.

52. Greater Yellow-legs. Totanus melanoleucus. A migrant, not common. Mr. Woodruff has noted occurrences in Litchfield from May 23 to June 9, and on Oct. 30, 1905. Mr. Stevens has taken and seen several in Canaan in September, and Mr. Williams sees them quite frequently in the fall.

53. Lesser Yellow-legs. Totanus flavipes. A rare migrant. Mr. Stevens repeatedly saw a small flock feeding on a flat along the Housatonic River during a whole week in late August, 1907. Mr. Austin saw a flock of seven by Mud Pond, Kent, in August, 1902. Mr. Williams has met with but one specimen, about eight years ago, in September.

54. Solitary Sandpiper. Helodromas solitarius. A fairly common migrant in spring and fall.

55. Bartramian Sandpiper, or Upland Plover. Bartramia longicauda. Once quite common, but now scarce. A few scattering ones appear as migrants, and now and then a pair breed. In May, 1902, Mr. Hanson found a pair in a field, in Torrington, evidently breeding, for on two occasions they made a great fuss. He usually sees a few each fall. Mr. Williams has not seen any since three or four 


\section{BIRDS OBSERVED IN LITCHFIELD COUNTY}

summers ago. He showed me a set of eggs which he took in Winchester, June 8, 1879.

56. Spotted Sandpiper. Actitis macularia. Common summer resident, found nearly everywhere.

57. Kildeer. Oxyechus vociferus. Another formerly common summer resident, now rarely breeding, and only oceasional as a migrant. Mr. Woodruff finds it as a rare migrant in Litchfield. Mr. Hanson showed me a mounted specimen shot from a flock of yellow-legs, in Burrville. Mr. Williams sees a few nearly erery spring and fall, and has a set of eggs which he took in Wineliester about twenty years ago.

58. Semipalmated Plover. Egialitis semipalmata. A rare migrant, wandering inland from the coast, and doubtless appearing occasionally along the larger lakes. The only positive record which I can quote is of one noted by Mr. Sanford June 3, 1905.

59. Bob-white. Colinus virginianus. Until the winter of 1903-4 a common resident everywhere. The severity of that and the following winter nearly exterminated the species, and now very few can be found.

60. Ruffed Grouse. Bonasa umbellus. A common resident. In the spring or summer of 1907 there was a widespread destruction of the grouse, or failure to raise young, throughout the northeastern Cnited States, and at present the species seems to be greatly reduced from its previous abundance.

61. Canadian Ruffed Grouse. Bonasa umbellus togata. All the four specimens of Ruffed Grouse in the collection of Mr. Woodruff from Litchfield were found by Doetor Bishop, upon comparison with his series, to be of this form. Messrs. Austin and Hanson have noted these very gray birds. Probably the form occurs regularly.

62. Mouming Dove. Zenaidura macroura. A rather scarce summer resident. I have seen an occasional individual or pair in Kent.

63. Turkey Vulture or Buzzard. Carthartes aura. A rare straggler in summer. One was caught alive, slightly 296 


\section{BIRDS OBSERVED IN LITCHFIELD COUNTY}

wounded, in New Milford, August, 1902, and about a week later I drove to the place and secured it. On the way home I saw another flying about, perhaps the mate. Mr. Hanson saw one in Torrington on August 21 of that same year, which was staying about some fish refuse.

64. Marsh Hawk. Circus hudsonius. A moderately common summer resident.

65. Sharp-shinned Hawk. Accipiter velox. A moderately common summer resident.

66. Cooper's Hawk. Accipiter cooperi. Common summer resident, occasional in winter. This is the species which does the greater part of the damage to poultry, for which other harmless or useful hawks are apt to get the blame.

67. Goshawk. Accipiter atricapillus. A winter visitor from the North, usually rare. In some winters, however, as in 1906-7, they appear in considerable numbers. Mr. Williams found a nest in Winchester, about fifteen years ago. It was in a chestnut tree, sixty feet up, and contained two eggs. He shot the female for identification, and has the eggs and full data. This is a unique record.

68. Red-tailed Hawk. Buteo borealis. Common summer resident in most parts of the County, and frequent throughout the year.

69. Red-shouldered Hawk. Buteo lineatus. Though a common summer resident south of the County along the Sound, it has been found to nest but seldom in these hill-towns, where it is, however, a common migrant.

70. Broad-winged Hawk. Buteo platypterus. Common summer resident, abundant in spring and fall migrations, in which it sometimes appears in large, loose flocks.

71. Bald Eagle. Haliætus leucocephalus. Occasionally scen from spring to fall, but is seldom known to breed, though it occasionally does so. Late in April, about a dozen years ago, Mr. Williams found, in Winsted, a nest on a rocky ledge which contained two good-sized young. Some years previously he had found another nest in an 


\section{BIRDS OBSERVED IN LITCHFIELD COUNTY}

unclimbable tree, and also has seen young which could not have been raised far off.

72. Pigeon Hawk. Falco columbarius. A not common migrant. I see one now and then, and Mr. Williams meets them rather frequently in fall, less so in spring.

73. Sparrow Hawk. Falco sparverius. A rather uncommon summer resident. I have seen two in mid-winter, and have been told of another such occurrence.

74. American Osprey, or Fish Hawk. Pandion haliætus carolinensis. A migrant, usually rather scarce, but quite common along rivers, especially the Housatonic. Mr. Williams knew one pair to nest a number of years ago, but they still do this commonly in certain localities along the Sound.

75. Barn Owl. Strix pratincola. An accidental visitor. Mr. Woodruff has one specimen taken in Litchfield. Mr. Williams was shown by Mr. Horace Kinney a nest in an old factory building in Winsted, about fifteen years ago, which contained six young. He visited the place the next season, and took a set of seven eggs, which he still has, with the data.

76. Long-eared Owl. Asio wilsonianus. An uncommon resident, seen mostly as a migrant. Mr. Williams found a nest containing three young, an old squirrel's nest fixed over, in Winchester, the middle of May, some fifteen years ago.

77. Short-eared Owl. Asio accipitrinus. A rather rare migrant, commoner along the coast.

78. Barred Owl. Syrnium varium. Not an uncommon migrant, but scarce as a summer resident, though commoner near the Sound. Mr. Williams has found three nests in Winchester, and Mr. E. H. Austin has seen it in winter.

79. Richardson's Owl. Nyctale tengmalmi richardsoni. On Nov. 12, 1906, a specimen in good plumage was picked up dead in Kent, and brought to me. I now have it mounted. This is the only record for the County and the second for Connecticut. 


\section{BIRDS OBSERVED IN LITCHFIELD COUNTY}

80. Saw-whet, or Acadian Owl. Nyctala acadica. Frequent as a migrant and rare as a summer resident. Mr. Williams found a pair occupying an old crow's nest, in Winsted, twelve to fifteen years ago. It was the middle of May, and there were three young. They occur in winter, and are sometimes found in buildings or picked up dead. Hunters occasionally flush them in bushy tracts in the fall.

81. Screech Owl. Megascops asio. Common resident throughout the year.

82. Great Homed Owl. Bubo virginianus. Rather common in wild, mountainous sections of the County, increasingly scarce in others. Owing to its loud hootings its presence is more easily detected than that of some other owls.

83. Snowy Owl. Nyctea nivea. A rare, irregular visitor from the North, more apt to occur along the coast.

84. Yellow-billed Cuckoo. Coccyzus americanus. A not common summer resident.

85. Black-billed Cuckoo. Coccyzus erythropthalmus. A rather common summer resident, more so than the preceding.

86. Belted Kingfisher. Ceryle alcyon. A common summer resident near bodies of water. They sometimes winter, of which three cases have been reported to me.

87. Hairy Woodpecker. Dryobates villosus. Resident throughout the year, not common, but generally distributed.

88. Northern Domny Woodpecker. Dryobates pubescens medianus. Quite common throughout the year.

89. Yellow-bellied Sapsucker. Sphyrapicus varius. A migrant, not very common, but sometimes fairly so in the fall. Some fifteen years ago Mr. Williams found two nests in Winchester, to verify one of which he shot the birds, and he still has eggs and data. He believes that they still breed, as he occasionally hears their notes in the nesting season. The region where he lives, including the neighboring towns of Litchfield, Norfolk, Winsted, and others, are of very high elevation, and are somewhat Canadian in their fauna, flora and climate. The season is fully two weeks later than in the southern part of the State. Careful 


\section{BIRDS OBSERVED IN LITCHFIELD COUNTY}

exploration would surely yield many rarities of northern birds.

90. Pileated Woodpecker. A rare visitor from the North, usually only in winter. I have four records reported to me of occurrence in winter during the last ten years, some quite recent. Mr. Hanson foumd a nest in Torrington, May 30,1901 , twenty feet up a pine tree, a very large cavity, with one young bird about a week old. Mr. Williams has found nests a dozen ycars and more back. This is further eridence of the Canadian aspect of the region.

91. Red-headed Woodpecker. Melanerpes erythrocephalus. A rare migrant and summer resident. A pair were noted in Kent, May, 190\%. Mr. Austin has occasionally seen one in Kent or New Milford. Mr. Woodruff has noted three in autumn. On June 23, 1906, he took a set of four fresh eggs in Litchficld. MLr. Williams was told of a pair breeding in Torrington some years ago.

92. Northem Flicker. Colaptes auratus luteus. A common summer resident.

93. Whippoorwill. Antrostomus vociferus. A common summer resident in most parts of the County.

94. Nighthawk. Chordeiles virginianus. A locally common summer resident, but they have notably declined in numbers in the past six years, both in my vicinity and throughout the State. In the fall migration they appear in large scattered flocks.

95. Chimney Swift. Chætura pelagica. A common summer resident, very conspicuous.

96. Ruby-throated Hummingbird. Trochilus colubris. A common summer resident.

97. Kingbird. Tyrannus tyrannus. A common summer resident.

98. Crested Flycatcher. Myiarchus crinitus. A rather scarce summer resident.

99. Phœbe. Sayornis phœbe. Abundant summer resident, but never has been known to occur in winter, despite reports to the contrary. 
100. Olive-sided Flycatcher. Nuttallornis borcalis. A rare migrant. I saw one unmistakably on May 31, 1907, and Mr. Woodruff shot one in Litclifield on Sept. 15, 1905.

101. Wood Pewee. Contopus virens. Rather a common summer resident, varying locally.

102. Yellow-bellied Flycatcher. Empidonax flaviventris. A rare migrant. I have met two or three in May. Mr. Woodruff has also noted them in spring in Litchfield, and on May 20, 1905, he saw ten of them.

103. Alder Flycatcher. Empidonax traillii alnorum. Summer resident and migrant, irregularly distributed, usually considered rare, perhaps because so silent and retiring. I have known of but one pair in Kent, but Mr. Woodruff finds it a common breeder in Litchfield in wet pastures and open meadows in which grow clumps of low alder bushes. Search in similar localities elsewhere may reveal it.

104. Least Flycatcher. Empidonax minimus. A common summer resident.

105. Horned Lark, or Shore Lark. Otocoris alpestris. An occasional winter visitor, occurring in small flocks, or singly, sometimes in flocks of Snow Buntings. It is much more common along the coast. On March 7, 1908, I saw about thirty in Lakeville, in three flocks.

106. Prairie Horned Lark. Otocoris alpestris praticola. A rather rare summer resident and migrant. Pairs evidently nesting have been reported to me from Litchfield and Goshen. Mr. J. S. Dutcher says that a pair bred in Watertown, in 1904. Mr. John Gath took a nest with four eggs in Torrington, on May 24, 1891, and collected the female. The eggs were identified by Dr. C. Hart Merriam.

107. Blue Jay. Cyanocitta cristata. Common throughout the year.

108. American Crow. Corvus brachyrhynchos. Common throughout the year.

109. Starling. Sturnus vulgaris. Successfully introduced from 


\section{BIRDS OBSERVED IN LITCHFIELD COUNTY}

Europe in 1890 in Central Park, New York City. They are resident throughout the year wherever found, and have spread, mostly coastwise, to Philadelphia and New London, Conn., respectively. The first record for this County of which I learned was given me by Mr. J. S. Dutcher, who reports a pair seen breeding in Watertown in the spring of 1907 . In very few years they will probably be a familiar sight in all our towns.

110. Bobolink. Dolichonyx oryzivorus. A fairly common summer resident, though somewhat irregularly distributed.

111. Cowbird. Motothrus ater. A common summer resident. 112. Red-winged Blackbird. Agelaius phœniceus. An abundant summer resident, very rarely found in winter.

113. Meadowlark. Sturnella magna. A summer resident, frequent, but hardly common.

114. Orchard Oriole. Icterus spurius. A summer resident, rare in the towns of higher elevation, but in the Housatonic Valley I find it not uncommon locally. Mr. Williams has seen but one in Winchester.

115. Baltimore Oriole. Icterus galbula. A common summer resident.

116. Rusty Blackbird. Euphagus carolinus. A rather common migrant.

117. Purple Grackle, or Crow Blackbird. Quiscalus quiscula. Locally common as a summer resident, usually in towns and villages, where it nests in evergreens in gardens.

118. Bronzed Grackle. Quiscalus quiscula æneus. Indistinguishable from the preceding except in hand, this form occurs more as a migrant, usually breeding a little further north. A breeding specimen, however, examined by Mr. Woodruff in Litchfield proved to be of this form.

119. Evening Grosbeak. Cocothraustes vespertinus. A very rare and irregular winter visitor, usually appearing, if at all, in flocks. In 1890 there was a notable irruption of the species into the United States from the far North. In this County they were noted by Messrs. Austin, Hanson, and others. 


\section{BIRDS OBSERVED IN LITCHFIELD COUNTY}

120. Pine Grosbeak. Pinicola enucleator. An irregular winter visitor, more often entirely absent, but in occasional winters appearing in flocks, sometimes in large numbers, as in the winter of $1906-7$.

121. Purple Finch. Carpodacus purpureus. A fairly common summer resident, occasionally appearing in flocks in winter.

122. House Sparrow, or English Sparrow. Passer domesticus. An abundant resident, introduced from Europe. A veritable pest.

123. American or Red Crossbill. Loxia curvirostra minor. An irregular winter visitor, appearing under the same conditions as the Pine Grosbeak, and usually the same winters. In the winters of 1899-1900 and 1906-7 there were great numbers of the various northern birds.

124. White-winged Crossbill. Loxia leucoptera. The same remarks apply to this species as to the preceding. The present species is usually considered the scarcer of the two, but in my experience it has been rather the commoner.

125. Redpoll. Acanthis linaria. Another of the irregular winter visitors from the North, and in my experience less often seen than the Crossbills.

126. American Goldfinch. Astragalinus tristis. A common resident, especially in summer, but it is frequently seen in flocks in winter. It is the latest of our birds to breed.

127. Pine Siskin. Spinus pinus. Another irregular winter visitor.

128. Snowflake, or Snow Bunting. Passerina nivalis. Winter visitor from the Arctic regions. Less irregular than the Crossbills and others, it is found nearly cvery winter in flocks, but is not common inland, though quite so on the coast.

129. Lapland Longspur. Calcarius lapponicus. A rare and irregular winter visitor to New England. On Feb. 12, 1905 , I saw clearly, within a few feet, one of these birds feeding on droppings in a road with two Snow Buntings. 
Mr. Williams saw a flock of seven or eight about four years ago in Winchester, about the middle of October.

130. Vesper Sparrow. Poœectes gramineus. A rather common summer resident.

131. Savanna Sparrow. Passerculus sandwichensis savanna. A rather uncommon summer resident, locally distributed, but abundant along the coast. Messrs. Woodruff and Williams both find them nesting in their vicinity.

132. Grasshopper Sparrow. Cotumiculus savannarum passerinus. A summer resident, not common.

133. Henslow's Sparrow. Ammodramus henslowi. A rather rare summer resident, but probably overlooked owing to its secretive habits. Mr. Woodruff finds a number of pairs in Litchfield, and Dr. L. B. Bishop found it breeding in Warren.

134 Nelson's Sharp-tailed Sparrow. Ammodramus caudacutus nelsoni. A variety of the Sharp-tailed Sparrow so common on salt marshes along the coast. It is a rare migrant, and I know of but one County record, a specimen shot by Mr. Woodruff in Litchfield, on Sept. 28, 1906.

135. White-crowned Sparrow. Zonotrichia leucophrys. A rather rare migrant. I have met with but two in Kent.

136. White-throated Sparrow. Zonotrichia albicollis. A common migrant. Mr. Woodruff shot a male in Litchfield on June 26,1906 , in full song, doubtless breeding-a unique record.

137. Trce Sparrow. Spizella monticola. A common winter resident.

138. Chipping Sparrow. Spizelia socialis. An abundant summer resident.

139. Ficld Sparrow. Spizella pusilla. A common summer resident.

140. Junco, or Snowbird. Junco hyemalis. Common as a migrant, and occasionally it winters.

141. Song Sparrow. Melospiza cinerea melodia. An abundant summer resident, and occasional in winter. 


\section{BIRDS OPSERVED IN LITCHFIELD COUNTY}

142. Swamp Sparrow. Melospiza georgiana. A common summer resident.

143. Fox Sparrow. Passerella iliaca. A rather common migrant.

144. Towhee, or Chewink. Pipilo erythropthalmus. A common summer resident.

145. Cardinal. Cardinalis cardinalis. A rare visitor. Mr. Williams saw a male, with full crest, in Winchester, in an apple tree late in May, about eight years ago. It is known to occur elsewhere in the State.

146. Rose-breasted Grosbeak. Zamelodia ludoviciana. A rather common summer resident.

147. Indigo Bunting, or Indigo-bird. Cyanospiza cyanea. A rather common summer resident.

148. Scarlet Tanager. Pyranga erythromclas. Quite a frequent summer resident, though hardly common.

149. Purple Martin. Progne subis. Formerly a common summer resident, but killed off by cold storms in the nesting season. I have seen none for several years, and then only in migration, nor has Mr. Woodruff since 1903.

150. Eave or Cliff Swallow. Petrochelidon lunifrons. Summer resident, locally common.

151. Barn Swallow. Hirundo erythrogaster. A common summer resident.

152. Tree Swallow, or White-bellied Swallow. Iridoprocne bicolor. A summer resident, locally common or scarce, not found in anything like the abundance of former years.

153. Bank Swallow. Riparia riparia. A summer resident, locally distributed, common in some towns, rare in others.

154. Rough-winged Swallow. Stelgidopteryx serripennis. A very rare summer resident. Mr. Woodruff found a nest with seven fresh eggs in Litchfield, built in a Kingfishers' hole, June 13, 1905, and saw a pair at the same place the June following. Mr. Austin has seen one or more in New Milford, and I saw a specimen, one May, in Kent.

155. Bohemian Waxwing. Ampelis garrulus. An accidental visitor from the North, very rare. Mr. Hanson reports a 


\section{BIRDS OBSERVED IN LITCHFIELD COUNTY}

mounted specimen in the possession of a Mr. Hochstein, of Torrington, which was shot in that vicinity from a flock of Cedar-birds " in the fall of 1899, when the black cherries were ripe."

156. Cedar Waxwing, or Cedar-bird. Ampelis cedrorum. A common summer resident, which also occurs in winter in flocks.

157. Northern Shrike, or Butcher-bird. Lanius borealis. A winter visitor, not common.

158. Northern Loggerhead Shrike. Lanius ludovicianus migrans. A very rare visitor in Connecticut. I give it in this list on the authority of Mr. Williams, who, about fifteen years ago, found in Winchester, in the latter part of May, in an apple orchard, a nest with five eggs of this species. He has the eggs in his collection.

159. Red-eyed Vireo. Vireo olivaceus. A common summer resident.

160. Philadelphia Vireo. Vireo philadelphicus. A rare migrant. Mr. Woodruff secured one in Litchfield, on May 17, 1905, and another on Oct. 9, 1899.

161. Warbling Vireo. Vireo gilvus. Quite a common summer resident in tall shade trees in towns and villages, but not often seen elsewhere, except in migration.

162. Yellow-throated Vireo. Vireo flavifrons. A regular, but not common summer resident.

163. Blue-headed, or Solitary Vireo. Vireo solitarius. Not common as a migrant, but rare as a summer resident. Mr. Woodruff and I found one in full song in Litchfield, late in June, 1907. It was doubtless breeding.

164. White-eyed Vireo. Vireo noveboracensis. A rare summer resident. I have seen but one in Kent, but Mr. Woodruff has found it in Litchfield several times. Doctor Bishop found a pair in New Preston, June 10, 1900, and Mr. Williams has found one nest in Winchester.

165. Black and White Warbler, or Creeper. Mniotilta varia. Common summer resident.

166. Worm-eating Warbler. Helmitherus vermivorus. A rare 306 
summer resident. I saw a pair which I fully identified near my home in Kent, on May 25, 1907. I was unable to find them subsequently. In late July, 1904, Mr. Carlton Schaller, who is familiar with this species in the Middle States, saw in Kent an adult of this warbler feed one of a family party of fully fledged young.

167. Blue-winged Warbler. Helminthophila pinus. A rare summer resident or migrant. Mr. Woodruff has four records for Litchfield. Mr. George E. Hix, who is well acquainted with the species, saw two specimens in Kent in August, 1907. Doctor Bishop saw one in New Preston, June 10, 1900.

168. Golden-winged Warbler. Helminthophila chrysoptera. A rare summer resident or migrant. I saw it several times in Kent in May and June, 1907, and think that a pair bred near my home, but I was unable to discover the nest. Mr. Woodruff found specimens in Litchfield in 1905, from May 7 to June 1.

169. Nashville Warbler. Helminthophila ruficapilla. Rather common as a migrant, but less so as a summer resident, though not rare as such. On May 29, 1907, I found a nest in Kent with five eggs, and on July 5, 1906, saw a small flock of them in lonely woods in Salisbury.

170. Tennessee IVarbler. Helminthophila peregrina. Generally a rare migrant, but sometimes numerous in migratory bird-waves. Mr. Woodruff took five specimens in Litchfield, May 19-24, 1905, on the latter date noting at least six. Mr. J. S. Dutcher has likewise seen it temporarily common in Watertown. On June 3, 1907, I saw one in Kent so chilled in a cold rainstorm that I could almost catch it.

171. Parula Warbler. Compsothlypsis americana usneæ. A common migrant, breeding in small numbers, sometimes in straggling colonies, in swamps or tracts where the gray usnea moss hangs from the trees. There is quite a colony in Litchfield which was shown to me by Mr. Woodruff, and Mr. Williams found a small breeding 307 
colony in Winchester. I have seen a few in Kent in the nesting season.

172. Cape May Warbler. Dendroiea tigrina. A rare migrant. I have taken one in Kent in May, and Mr. Woodruff another in Litchfield, May 8, 1905.

173. Yellow Varbler. Dendroica æestiva. A common summer resident.

17-4. Black-throated Blue Warbler. Dendroica cærulescens. A common migrant, and locally common as a summer resident, breeding in the woods of the higher slopes, especially where there is mountain laurel undergrowth. The nests are built in low clumps of laurel, near the ground.

175. Myrtle Warbler. Dendroica coronata. Common as a migrant, and occasionally seen in winter in flocks.

176. Magnolia Warbler. Dendroica maculosa. A fairly common migrant. Mr. Woodruff found a male in full song in Litchfield, June 8, 1891, in a dense grove of hemlock, where it very probably was breeding.

177. Chestnut-sided IVarbler. Dendroica pennsylvanica. A common summer resident.

178. Bay-breasted Warbler. Dendroica castanea. An irregular and not common migrant, though occasionally in spring it appears in considerable numbers, while again it may not appear at all.

179. Blackpoll Warbler. Dendroica striata. A common migrant, the latest of the migrants in spring.

180. Blackburnian Warbler. Dendroica blackburnix. A not very common migrant, though sometimes it appears in May in fair numbers. It also occurs as a rare summer resident. Doctor Bishop took specimens in Salisbury, two males, June 19 and 20,1904 , and Mr. Woodruff saw and took specimens in Litchfield throughout the latter half of June, 1905. Dr. George Wolsey took one in Cornwall on June 25, 1879.

181. Black-throated Green Warbler. Dendroica virens. Common both as migrant and as summer resident. 


\section{BIRDS OBSERVED IN LITCHFIELD COUNTY}

182. Pine Warbler. Dendroica vigorsii. A rare migrant. Mr. Woodruff has noted it in Litchfield, but I have never met it in Kent, where there are hardly any pines.

183. Yellow Palm Warbler. Dendroica palmarum hypochrysea. A fairly common migrant, next in hardiness to the Myrtle Warbler. It usually arrives in April, and I have seen it as early as March 29.

184. Oven-bird. Seiurus aurocapillus. An abundant summer resident.

185. Water Thrush. Seiurus noveboracensis. A common migrant.

186. Louisiana Water Thrush. Seiurus motacilla. A rather scarce summer resident, apt to be found along wooded mountain brooks with steep banks.

187. Connecticut Warbler. Geothlypsis agilis. A regular but not common migrant in fall; rarely, if ever, found in spring migration.

188. Mourning Warbler. Geothlypsis philadclphia. A rare migrant. I have seen it surely once, and I think twice, in Kent, in May. Mr. Woodruff has one record of its occurrence in fall in Litchfield-Sept. 24, 1891.

189. Northern Yellow-throat. Geothlypsis trichas brachidactyla. A common summer resident.

190. Yellow-breasted Chat. Icteria virens. A summer resident, fairly common in low altitude, as along the Housatonic River, but rather rare on the higher parts of the County. Mr. Williams has found two nests in Winchester.

591. Hooded Warbler. IVilsonia mitrata. A very rare summer resident. It is found along the Sound, but the only County record of which I have learned is given by Mr. Williams, who found a nest eight or nine years ago in Winchester, containing four heavily incubated eggs, built in a small sprout, a foot and a half from the ground. I think he has the eggs and full data.

192. Wilson's Warbler. Wilsonia pusilla. Occurs sparingly as a migrant. 


\section{BIRDS OBSERVED IN LITCHFIELD COUNTY}

193. Canadian Warbler. Wilsonia canadensis. Common as a migrant. As a summer resident it is rare in most towns, but decidedly common in the elerated forests of the mountainous region of the northwest corner of the County and State.

194. American Redstart. Setophaga ruticilla. A common summer resident.

195. American Pipit, or Titlark. Anthus pennsylvanicus. A rather uncommon migrant, occurring in late fall and early spring in straggling flocks on bare, open places.

196. Mockingbird. Mimus polyglottos. Occurs irregularly in Southern New England in all seasons, but the only occurrence which $I$ have been able to trace for this County is of a pair found breeding in Winchester by Mr. Williams quite a number of years ago.

197. Catbird. Galeoscoptes carolinensis. An abundant summer resident.

198. Brown Thrasher. Toxostoma rufum. A common summer resident.

199. House Wren. Troglodytes ædon. A common summer resident.

200. Winter Wren. Olbiorchilus hiemalis. Not uncommon as a migrant, scarcer in winter. It has not hitherto been recorded as a summer resident in Connecticut. But on July 5 and 6,1906 , I found two pairs, the males in full song, in Sage's Ravine, Salisbury, clearly within the Connecticut boundary. It should occur also in Litchfield and Winchester. Mr. Austin sees a number each winter.

201. Short-billed Marsh Wren. Cistothorus stellaris. A rare summer resident. I have not detected any in Kent, but in Warren, the next town, Doctor Bishop found it in 1900. Mr. Woodruff showed me two nests in Litchfield, June 27,1907 , in a meadow. It is more common in migration.

202. Long-billed Marsh Wren. Cistothorus palustris. A rather rare migrant. It ought to be discovered breeding in reedy bogs. 


\section{BIRDS OBSERVED IN LITCHFIELD COUNTY}

203. Brown Creeper. Certhia familiaris americana. A fairly common migrant, and occasionally seen in winter.

204. White-breasted Nuthatch. Sitta carolinensis. A common resident throughout the year.

205. Red-breasted Nuthatch. Sitta canadensis. An irregular migrant, some seasons absent or rare, occasionally abundant. In years of abundance some are apt to winter. This was the case in the fall and winter of 1899-1900, when I found numbers in deep hemlock woods. Mr. Williams found a nest of this species in Winchester, June 1, 1876. He shot the female for identification, and showed me recently the nest, eggs and data.

206. Chickadee. Parus atricapillus. Common resident, less abundant in summer than in spring and fall.

207. Golden-crowned Kinglet. Regulus satrapa. A common migrant, occasional in winter.

208. Ruby-crowned Kinglet. Regulus calendala. Rather common as a migrant.

209. Wood Thrush. Hylocichla mustelina. A common summer resident.

210. Wilson's Thrush, or Veery. Hylocichla fuscescens. A common summer resident.

211. Gray-cheeked Thrush. Hylocichla aliciæ. A not common migrant, but some seasons, as in the spring of 1907, it seems fairly numerous. The kindred form, Bicknell's Thrush, certainly must occur, but I have no record. Though I am confident that I have seen it, it is too much like the Gray-cheeked to be distinguished from it afield with certainty.

212. Olive-backed Thrush. Hylocichla ustulata swainsoni. A common migrant.

213. Hermit Thrush. Hylocichla guttata pallasii. A common migrant and rather rare summer resident on the higher wooded elevations of the County. I found it in full song on Bear Mountain, Salisbury, on July 5, 1906, where Doctor Bishop had also previously found it, June 18, 1904. Mr. Milo B. Tobey, of Canaan, found a nest with 


\section{BIRDS OBSERVED IN LITCHFIELD COUNTY}

eggs there some years ago. Mr. Woodruff secured a young bird not fully grown in Litehfield, July 2, 1891.

214. American Robin. Merula migratoria. An abundant summer resident, occasionally found in winter.

215. Bluebird. Sialia sialis. A common summer resident, found sometimes in winter.

216. Yellow Rail. Porzana noveboracensis. A specimen was pieked up in New Milford the day following the great blizzard of Mareh, 1888, alive in a snow-drift, and was brought to Mr. Austin for identification. 


\section{INDEX}

Baldpate, 267

Bittern, American, 260-1

Least, 261

Blackbird, Cow, 151

Crow, 153-4

Red-winged, 15:-3

Rusty, 155

Swamp, 152-3

Biueliil, 267

Bluebird, 97, 245-8

Blue Peter, 259

Bobolink, 150-1

Bob-white, $93-6$

Bufflehead, 267

Bull-bat, 104

Bunting, Cow. See Cowbird.

Indigo. See Indigo-bird.

Snow, 157, 163-4

Butcher-bird, 197-8

Buzzard, Turkey, 56

Canary, Wild, 162, 223

Canvasback, 267

Cardinal, 157, 175

Catbird, 230, 236-7

Cedar-bird, 194-6

Chat, Yellow-breasted, 209, 217, 222

Chebec, 13t-5

Chewink, 157, 172-3

Chickadee, 130, 165, 2\$3-4

Carolina, 244

Hudsonian, 2t4

Coot, American, 259

Cowbird, 151-2, 202-5, 225

Crane, Blue, 259

Creeper, Black and White, 208, 213, 217 Brown, 249, 245

Crossbill, 157, 160

American, 160

Red, 160

White-winged, 160-1
Crow, American, 64, 139-43

Cuckoo, Black-billed, 7\%-81

Yellow-billed, 81

Dabchick, 271

Dove, Mlourning, 32-3

Duck, Black, 1, 2, 263-4

Dusky, 1, 2, 263-4

Greater Scaup, 267

Lesser Scaup, 267

Duck, Long-tailed, 267

Ruddy, 267

Summer, or Wood, 1, 2, 264-6

Eagle, Bald, 53

Golden, 54

Egret, American, 263

Finch, Pine. See Siskin. Purple, 157, 162, 194, 207

Flicker, 7ł, 87-9

Flycatcher, Acadian, 134

Alder, 135-8

Crested, 128-9

Least, 134-5

Olive-sided, 133

Traill's, 135

Yellow-bellied, $13 \pm$

Gadwall, 267

Gallinule, Florida, 259

Gnatcatcher, Blue-gray, 244

Golden-eye, American, 267

Goldfinch, American, 118, 157, 162-3

Goosander, 268

Goose, Canada, 268-9

Goshawk, American, 54-5

Grackle, Bronzed, 153

Purple, 153

Grebe, Holboell's, 270-1

Horned, 270 -3

Pied-billed, 270-1 


\section{INDEX}

Grosbeak, Evening, 160

Pine, $157,159,161-2$

Rose-breasted, 157, 173-4, 193

Grouse, Ruffed, 13, 26-31, 54 Pinnated, 32

Gull, American Herring, 269 Ring-billed, 269

Hawk, American Rough-legged, 54 American Sparrow, 53-4

Broad-ringed, 35-47, 88

Cooper's, 36-7, 47, 51-2, 55, 88, 219

Fish, 53

Hen, 55

Marsh, 53

Pigeon, 53

Red-shouldered, 48, 51, 63

Red-tailed, 48-51, 54, 88

Sharp-shinned, 51-2, 55, 222

Sparrow, 53-1

Hen, Heath, 32

Marsh, 259

Mud, 259

Prairie, 32

Heron, Black-crowned Night, 260

Great Blue, 259-60

Green, 261-3

Little Blue, 263

Yellow-crowned Night, 263

High-hole, 87

Hummingbird, Ruby-throated, 111-23

Indigo-bird, 157, 174

Jay, Blue, 144-6

Junco, 165-7

Kildeer, 253

Kingbird, 124-8

Kingfisher, Belted, 82-6

Kinglet, Golden-crowned, 244-5

Ruby-crowned, s44-5

Lark, Horned, 146

Prairie Horned, 147

Shore, 146

Longspur, Lapland, 16t-5

Loon, 270

Mallard, 267

Martin, Purple, 186-7
Meadowlark, 147-8

Western, 148

Merganser, American, 268

Hooded, 268

Red-breasted, 268

Mockingbird, 237-8

Mud-hen, 959

Nighthawk, 102-4, 109-11

Nuthatch, Red-breasted, 242

White-breasted, 242-3

Old Squaw, 267

Oriole, Baltimore, 148-9

Orchard, 149-50

Osprey, American, 53

Oven-bird, 89, 102, 208-9, 217, 227-8

Owl, Barn, 68

Barred, 58-63, 69, 75, 97

Great Gray, 75

Great Horned, 33, 58, 60-1, 69, 71-2

Hloot, 4,58

Long-eared, 63-8

Marsh, 68

Richardson's, 75-6

Saw-whet, $73-5$

Screech, 69- 72

Short-eared, 68

Snorry, 75

Partridge, 27

Peabody-bird, 168

Peter, Blue, 259

Pewee, Wood, 129, 132-3

Phobe, 129-32, 244

Pigeon, Passenger, 32

Pintail, 71, 267

Pipit, American, 299

Plover, American Golden, 253

Semi palmated, 253

Upland, 253

Quail. See Bob-white,

Rail, Carolina. See Sora.

Clapper, 259

King, 259

Little Black, 258-9

Virginia, 256-7

Yellow, 258-9 


\section{INDEX}

Redhead, 267

Redpoll, 157-9

Redstart, 102, 207-9, 217, 225-6

Reedbird, 151

Ring-neck, 253

Robin, American, 33, 97, 207, 245-9, 255 Swamp, 172

Sandpiper, Bartramian, 253

Least, 253

Semi-palmated, 253

Solitary, 254

Spotted, 253-5

Sapsucker, Yellow-bellied, 94

Scoter, American, $\approx 67$

Surf, 267

White-winged, 267

Shelldrake, 268

Shrike, Nerthern, 197-8

Loggerhead, 198

Siskin, Pine, 15\%-8, 160

Snipe, Wilson's, $29-3$

Snowbird, 165

Snowflake, 163

Sora, 256-7

Sparrow, Chipping, 102, 166, 169, 171

English, 165, 178-9

Field, 166, 169

Fox, 166

Grasshopper, 168, 170

Henslow's, 168

Ipswich, 167

Lincoln's, 166

Savanna, 167, 1\%0

Seaside, 167

Sharp-tailed, 167

Song, 102, 165-6, 169

Swamp, 166, 169

Tree, 165-6

Vesper, 167, 170

White-crowned, 168

White-throated, 168

Swallow, Bank, 181-6

Barn, 178-80

Chimney, 187

Cliff. See Eave.

Eave, 178, 181-?

Rough-winged, 186

Tree, 182-1

Swift, Chimney, 187-90
Tanager, Scarlet, 89, 106, 191-4

Teal, Blue-winged, 267

Green-winged, 267

Tern, Black, 269

Common, 269

Thrasher, Brown, 230-6

Thrush, Alice's, 245-7

Bicknell's, 245-6

Hermit, 245-7

Louisiana Water, 210, 217, 220-1

Olive-backed, 245-7

Water, 209

Wilson's, 245-7, 249

Wood, 102, 194, 245, 247, 249-50

Titlark, 229

Titmice, 243

Towhee, 17\%-3

Turkey, Wild, 32

Veery, 102, 245-7, 249

Vireo, Blue-headed, 198-200

Red-eyed, 89, 199, 201-5

Solitary, 198-200

Warbling, 200-1

White-eyed, 201

Yellow-throated, 200

Vulture, Turkey, 56

Warbler, Bay-breasted, 207-8, 214

Black and White, 208, 213, 217, 226-7

Blackburnian, 34, 207-8

Blackpoll, 213-4

Black-throated Blue, 208, 217, 219-20

Black-throated Green, 207-9, 215, 217, 221-2

Blue-winged, or Blue-winged Yellow, 213,217

Cærulean, 214

Canadian, 209, 212, 217

Cape May, 207

Chestnut-sided, 135, 209, 217, 224-5

Connecticut, 213

Golden-winged, 212, 217

Hooded, 214, 217

Kentucky, 214, 217

Magnolia, 207

Mourning, 213

Myrtle, 207-9, 214-5

Nashville, 210, 217-9

Parula, 207, 209, 217, 22 


\section{INDEX}

Warbler, Pine, 213, 215, 217

Prairie, 213

Tennessee, 212

Wilson's, 209

Worm-eating, 211-2

Yellow, 207, 209, 213, 217, 293-4

Yellow-Palm, 212, 215

Yellow-Redpoll, 212, 215

Yellow-throated, 214

Water Witch, 272

Waxwing, Bohemian, 194

Cedar, 194

Whippoorwill, 102-9

Whistler, 267

Woodcock, American, 13-22

Woodpecker, American Thrce-toed, 96
Woodpecker, Arctic Three-toed, 87, 96 Downy, 94, 96-9

Golden-winged, 87-9t

Hairy, 94, 96-100

Pileated, 87, 95-6, 99

Red-headed, 88, 94-5

IVren, Carolina, 240

House, 938-9

Long-billed Marsh, 240-1

Short-billed Marsh, 240-1

Winter, 240

Yellow-hammer, 87

Yellow-legs, Greater, or Winter, es3

Lesser, or Summer, 253

Yellow-throat, Northern, 209, 21\%. 228-9 








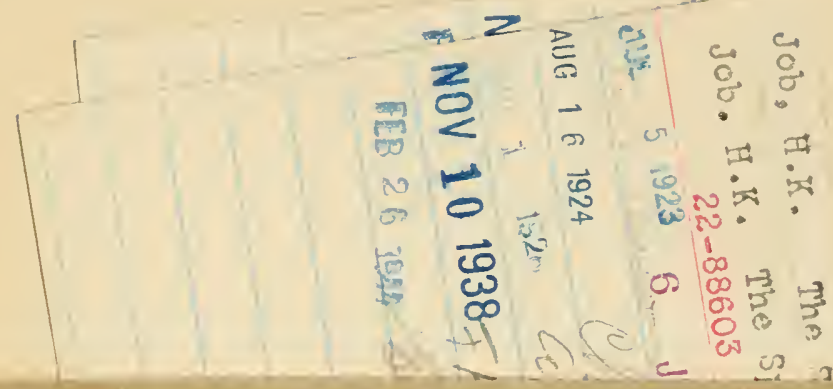


